
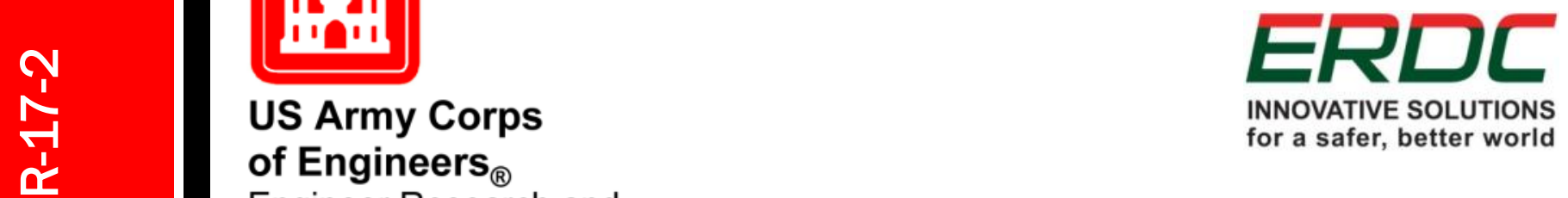

INNOVATIVE SOLUTIONS

for a safer, better world

Engineer Research and

Development Center

\title{
Energy Conservation in Historic Buildings
}

David M. Underwood, Brett N. Garret, and Tapan C. Patel

January 2017

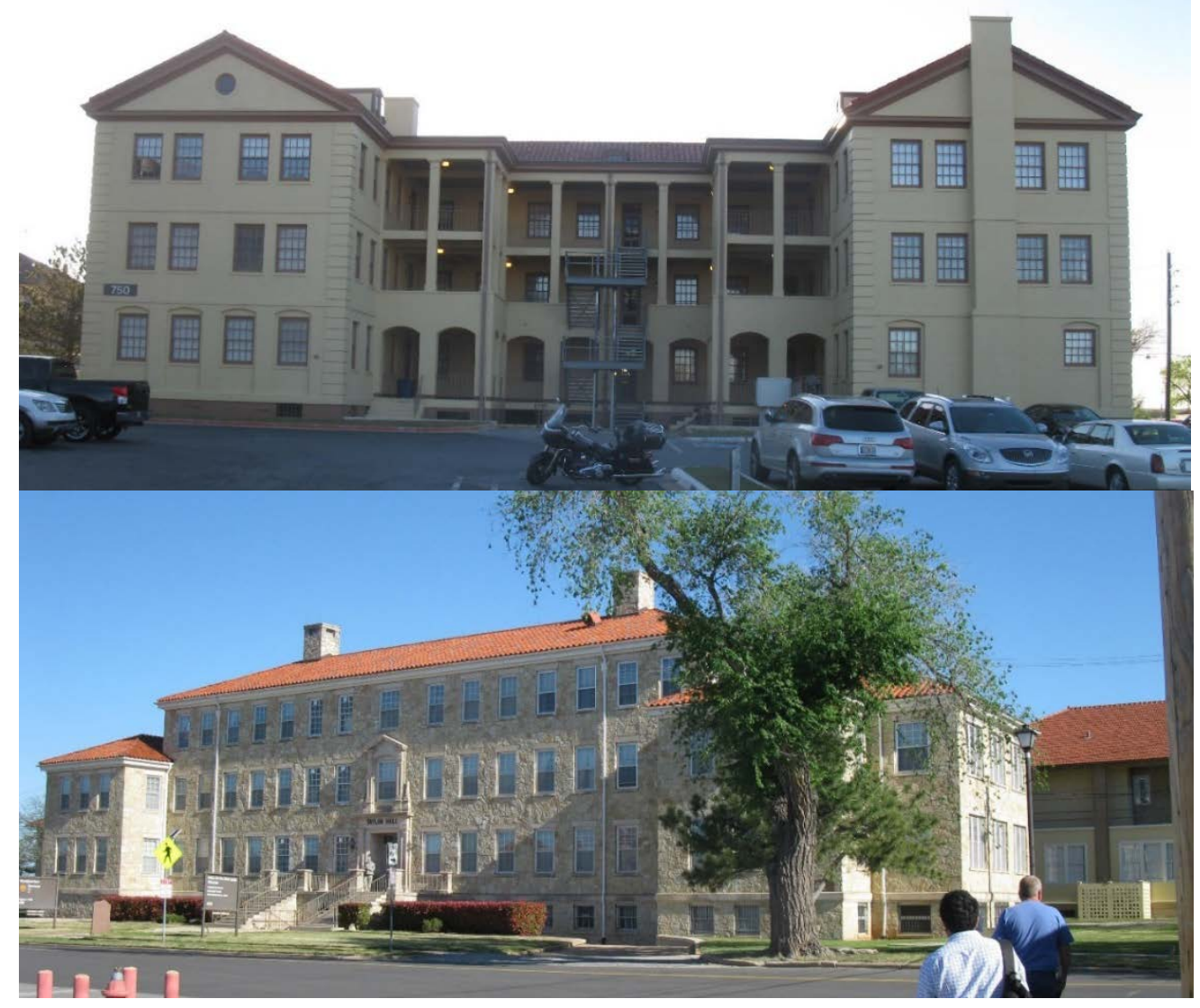

Fort Sill, OK, Bldgs. 750 (top) and 462 (bottom) 
The U.S. Army Engineer Research and Development Center (ERDC) solves the nation's toughest engineering and environmental challenges. ERDC develops innovative solutions in civil and military engineering, geospatial sciences, water resources, and environmental sciences for the Army, the Department of Defense, civilian agencies, and our nation's public good. Find out more at www.erdc.usace.army.mil.

To search for other technical reports published by ERDC, visit the ERDC online library at http://acwc.sdp.sirsi.net/client/default. 
ERDC/CERL TR-17-2

January 2017

\section{Energy Conservation in Historic Buildings}

David M. Underwood, Brett N. Garret, and Tapan C. Patel

U.S. Army Engineer Research and Development Center (ERDC)

Construction Engineering Research Laboratory (CERL)

2902 Newmark Dr.

Champaign, IL 61824

Final Report

Approved for public release; distribution is unlimited.

Prepared for Office of the Assistant Secretary of Defense for

Energy, Installations, and Environment (OASD[EI\&E])

Under Legacy Resource Management Program, Project Number15-777, "Identify Life Cycle Cost Benefits of Energy Efficiency in Historic Buildings" 


\section{Abstract}

This work reviewed the U.S. Department of Defense (DoD) stock of buildings that has either been declared historical or deemed eligible for historic building status. Six buildings at Fort Sill, OK, that represent commonly found buildings were selected to be studied for potential Energy Efficiency Measures (EEMs). Three historic buildings at Fort Bliss were also included in the analysis. Computer models of the buildings energy use were developed and used to estimate the potential energy savings of the various EEMs. Costs for the EEMs were estimated, simple paybacks were calculated, and the results were extrapolated to the 15 U.S. climate zones and summarized. A list of EEMs that may be applicable to historic buildings and a general guide to their effectiveness in various climates was developed.

DISCLAIMER: The contents of this report are not to be used for advertising, publication, or promotional purposes. Citation of trade names does not constitute an official endorsement or approval of the use of such commercial products. All product names and trademarks cited are the property of their respective owners. The findings of this report are not to be construed as an official Department of the Army position unless so designated by other authorized documents. 


\section{Executive Summary}

This work reviewed the U.S. Department of Defense (DoD) stock of buildings that has either been declared historical or deemed eligible for historic building status. From that list, six buildings at Fort Sill, OK, that represent commonly found buildings were selected to be studied for potential Energy Efficiency Measures (EEMs). Three historic buildings at Fort Bliss that had already been modeled in a previous study were also included in the analysis. Computer models of the buildings energy use were developed and used to estimate the potential energy savings of the various EEMs. Costs for the EEMs were estimated, simple paybacks were calculated, and the results were extrapolated to the 15 U.S. climate zones and summarized. The following results provide a list of EEMs that may be applicable to historic buildings and a general guide to their effectiveness in various climates:

- Note that the most general conclusion is that - as one might intuitively expect- all EEMs yield smaller savings and are therefore less economical in milder climates.

- Replacement of mechanical equipment controls (to allow setpoint and schedule changes) was by far the most cost effective measure with an average simple payback of less than 2 months for all buildings in all climate zones. The costs assumed were the minimum needed to allow setpoint and schedule changes. In many cases it is desirable to make changes to controls, such as installing Direct Digital Controls (DDC) for all equipment.

- Reduction of infiltration was also very effective with a payback of less than 5 years in all but $8 \%$ of the climate zone building combinations.

- Improvement of Wall insulation on the inside of exterior walls was also very cost effective (with a simple payback of less than 5 years) in nine of 15 zones, most of which were in the colder zones.

- Although Lighting retrofits typically yield very good paybacks, lighting retrofits did not yield very good paybacks in most of the modeled buildings for two reasons: (1) the lighting density in the buildings modeled was very low so almost no areas were found to be overlit, and (2) all of the buildings had been retrofitted with energy efficient lighting. It was therefore decided not to model the base case with less efficient lighting or with overlit conditions because lighting retrofits have already been done in most DoD buildings. This differs from the ap- 
proach taken for other EEMs such as scheduling in which, after modeling the building as found (referred to "As Is" in the modeling), the building was modeled without the EEM (scheduling) to determine the baseline. Therefore this result should regarded as an anomaly; in general, lighting controls retrofits should always considered.

- Improvement of Roof/Attic Insulation was found to rarely be a very good saver. Only Bldg. 441 had simple paybacks of less than 15 years, and then only in seven (cooler) climate zones.

- Replacement of Mechanical Equipment was found to have a relatively good payback. As expected, replacing chillers in warm climates and boilers in cold climates has a much better payback than the reverse.

- The use of Renewable Energy was found to be physically feasible in two buildings (3419 and 1803). Wind turbines would distract from the historic nature of the area. Photovoltaic (PV) panels could be installed on the roof of Bldg. 3419 as could water heating panels. However, there was not enough demand for hot water in this administrative building to justify this measure. PV has potential on Bldg. 3419, but the payback is relatively long at 21 to 40 years. In Bldg. 1803, the replacement of conventional boiler/chiller with ground source heat pumps and was found to have a good payback ( 1 to 7 years) depending on climate zone. Note that, although good payback was found even in the colder climate zones, it may not be practical in the colder climate zones. Also of note is that no costs were included for supplemental heating that may be needed in some climates.

- Improvement of Ground Floor Insulation was found to be somewhat cost effective with paybacks ranging from 5.4 to 9.9 years. This was found feasible in only one building, which has a crawl space type foundation that allows relatively easy access to insulate the floor.

Tables ES1 to ES9 summarize the analysis in the form of simple payback (Initial cost[\$]/Savings[\$]/year) for the various buildings and climate zones. Note that Bldgs. 441, 462, 463, 750, 1803, and 3419 are located at Fort Sill, OK, and Bldgs. 1, 115, and 1103 are located at Fort Bliss, TX. 

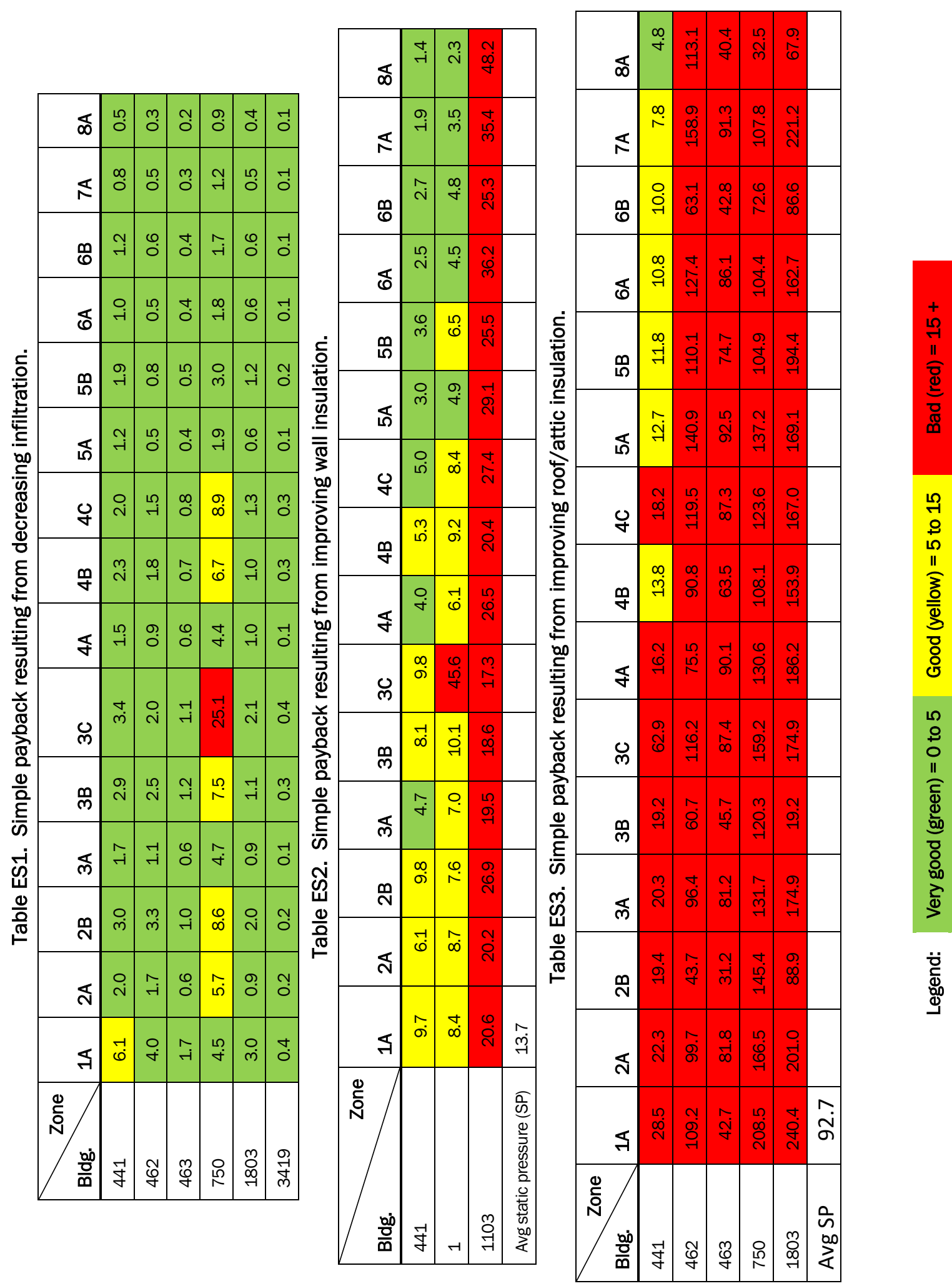


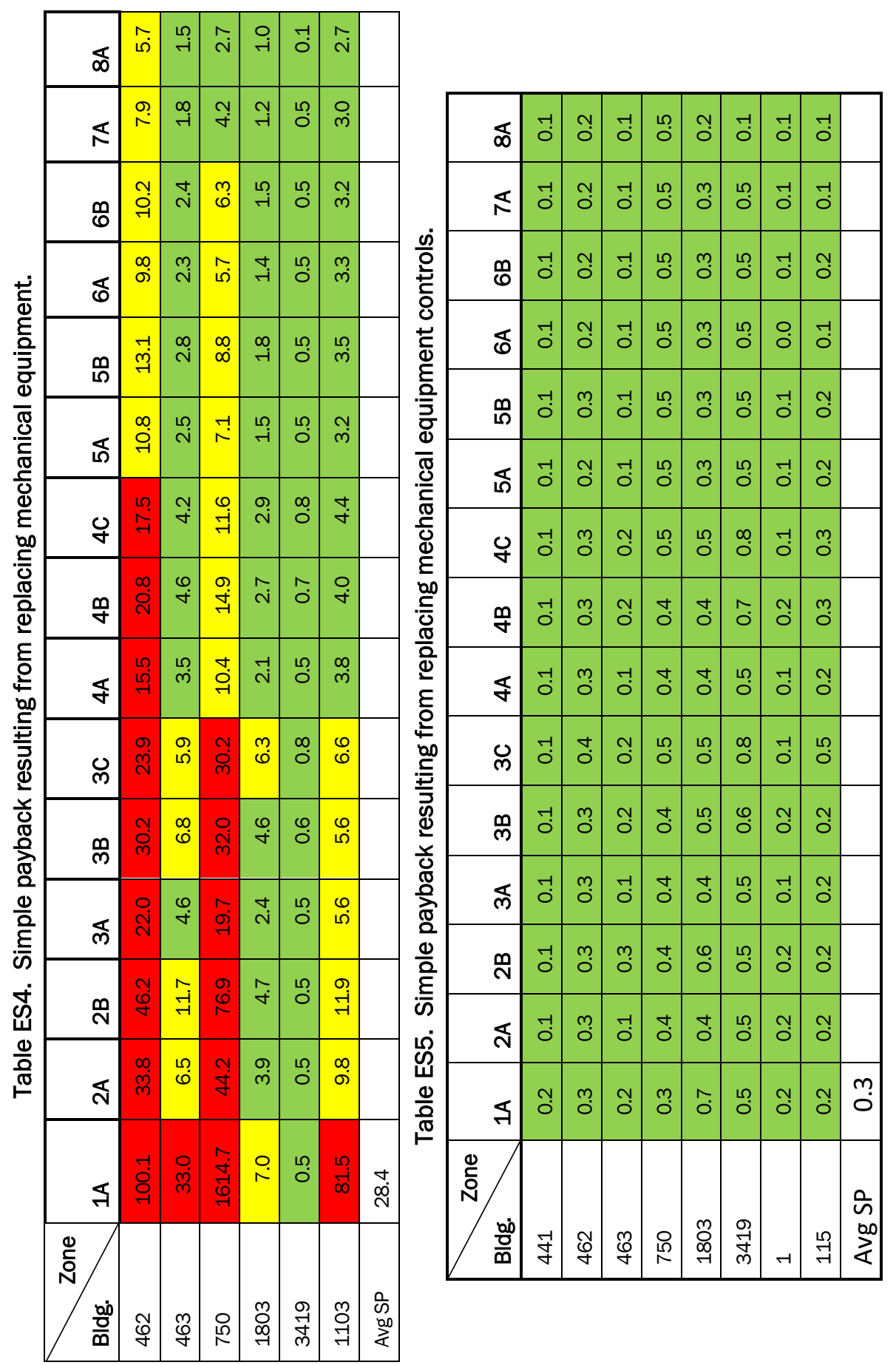



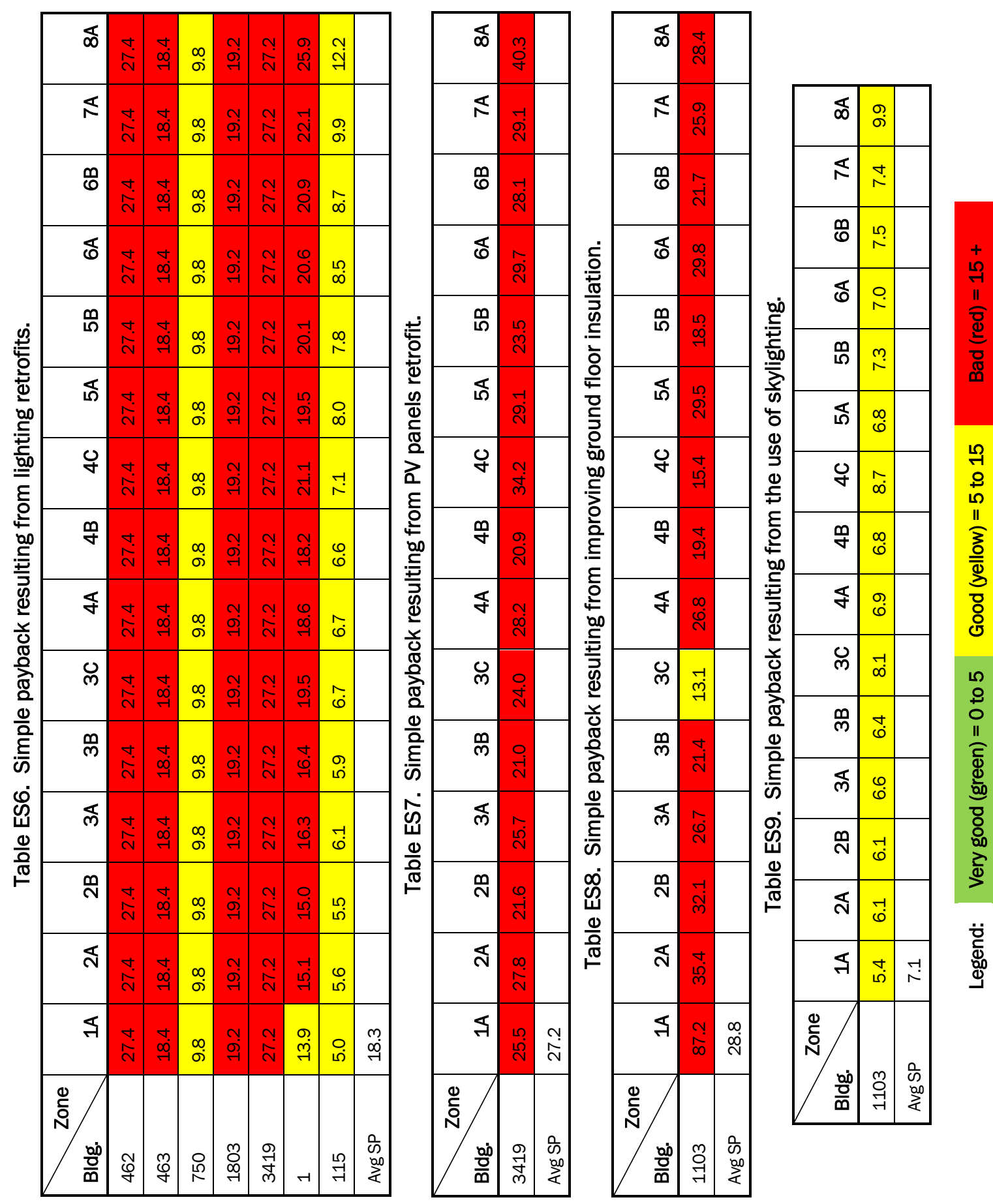


\section{Contents}

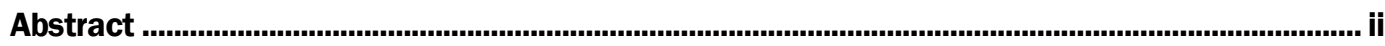

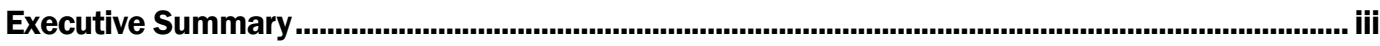

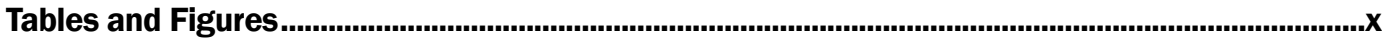

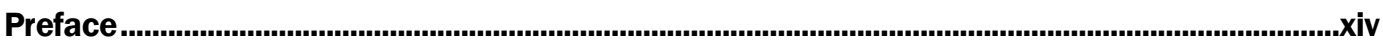

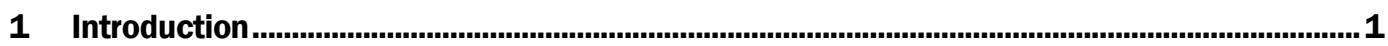

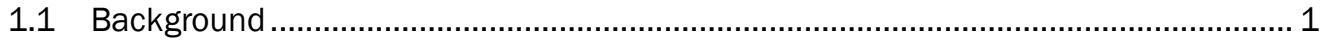

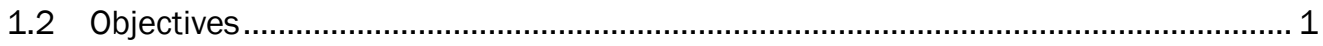

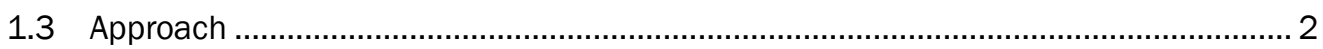

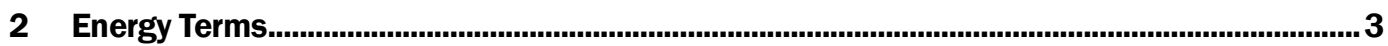

2.1 Heating and cooling degree days..................................................................... 3

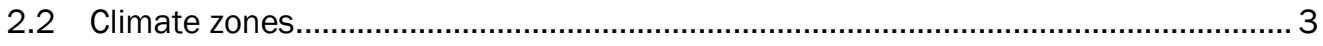

2.3 eQUEST - The Quick Energy Simulation Tool ................................................... 5

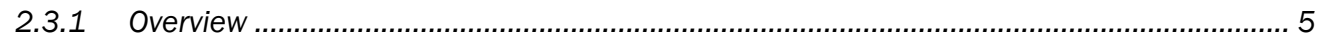

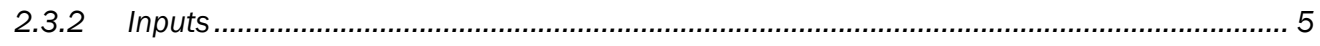

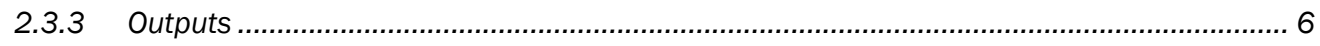

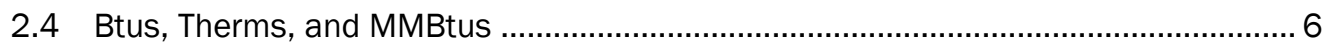

2.5 Watts, Kilowatts (kW), and Kilowatt-Hour (kWh) ................................................ 6

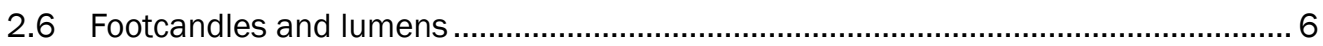

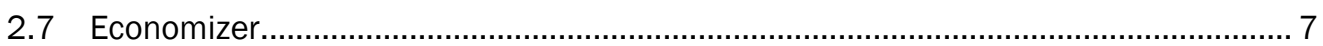

3 DoD Stock of Historic and Potentially Historic Buildings ....................................................... 8

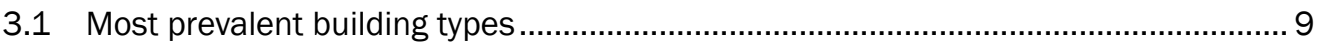

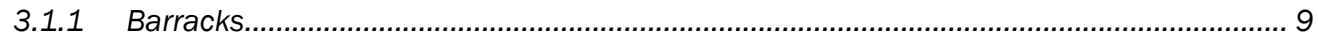

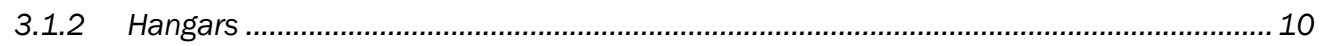

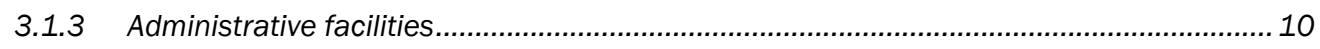

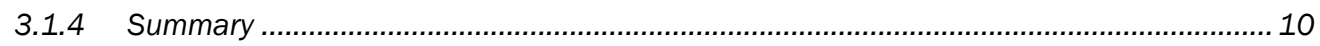

3.2 Selection of an Army installation ............................................................... 13

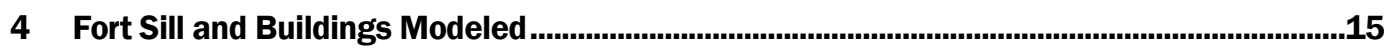

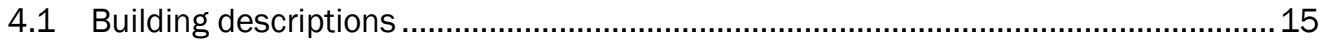

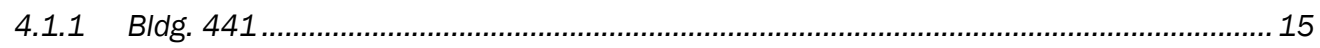

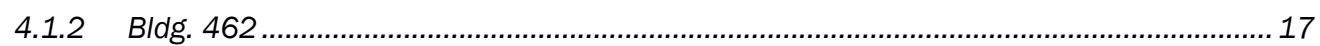

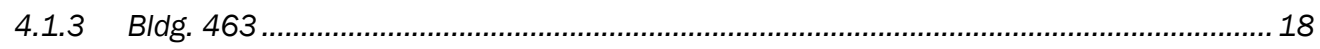

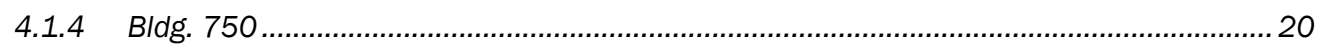

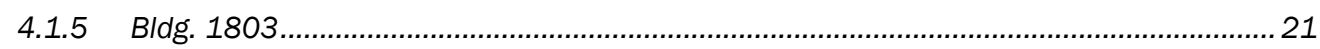

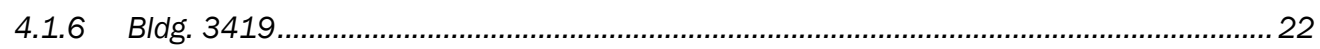

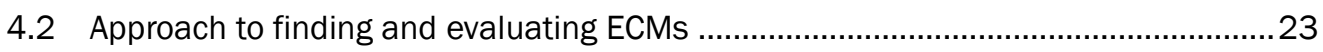

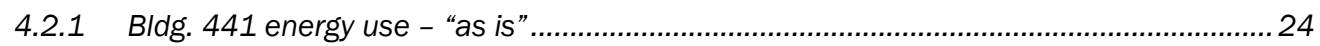

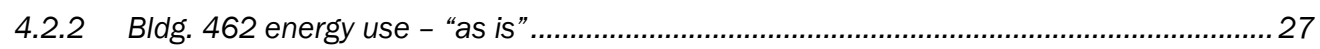

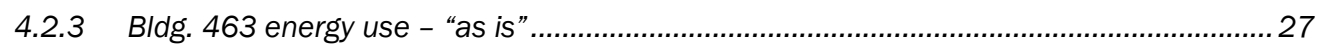




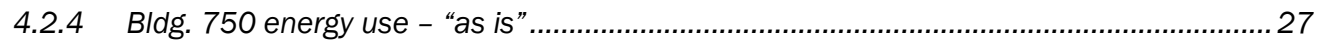

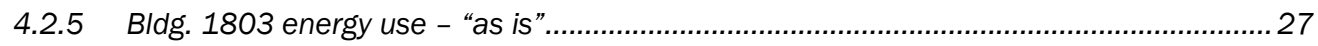

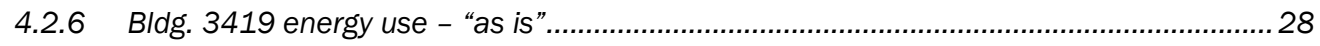

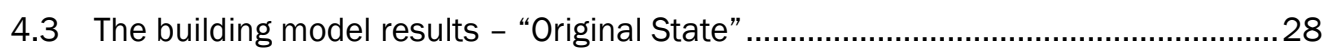

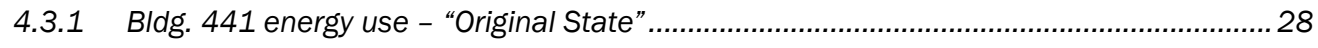

4.3.2 Bldg. 462 energy use - "Original State" ....................................................................... 28

4.3.3 Bldg. 463 energy use - "Original State" ....................................................................... 28

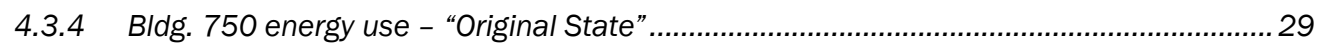

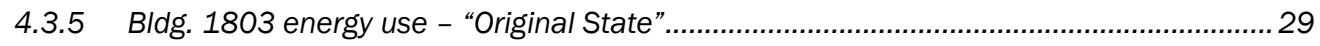

4.3.6 Bldg. 3419 energy use - "Original State"...................................................................... 29

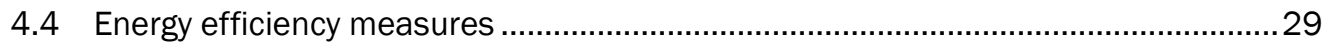

4.4.1 Bldg. 441 EEM Descriptions, implementation costs and savings by climate zone.............30

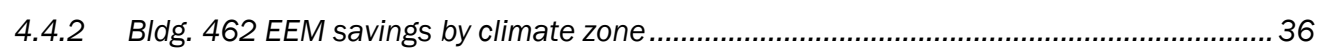

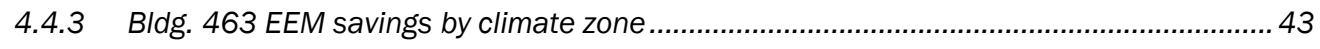

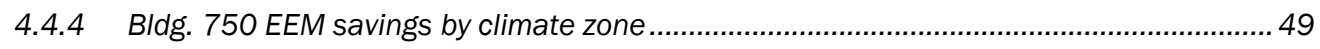

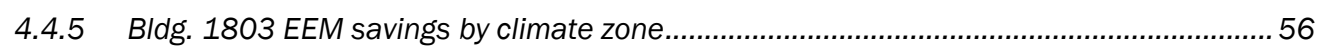

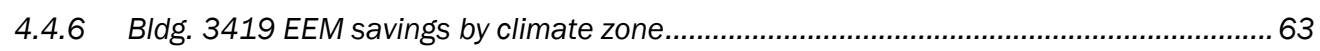

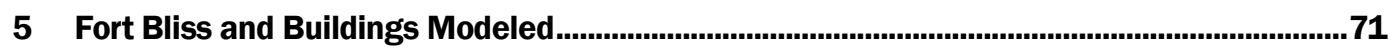

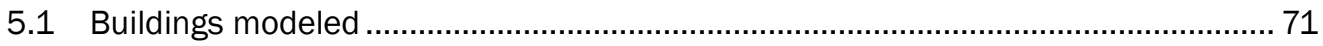

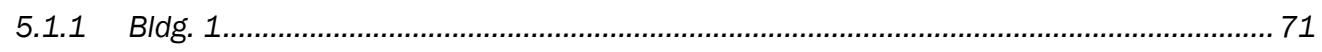

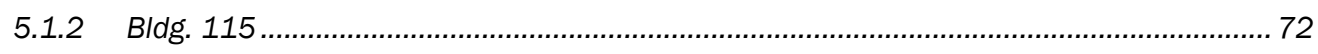

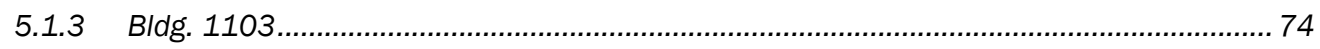

5.2 The building model results - "as is" ................................................................... 75

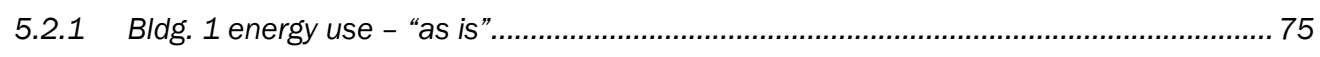

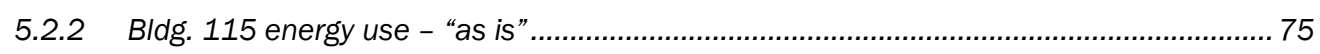

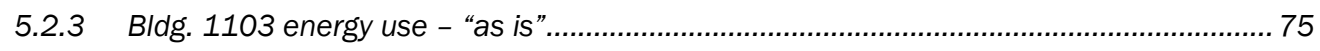

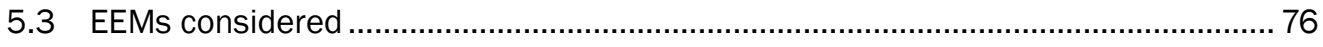

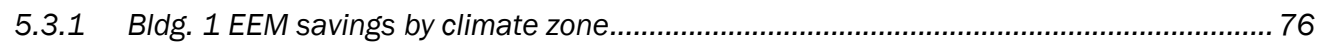

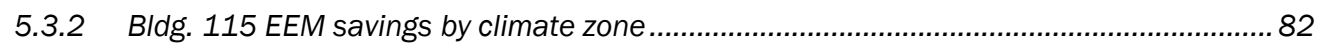

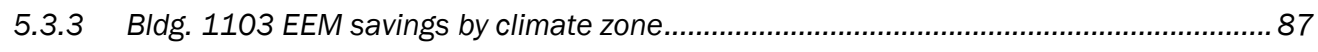

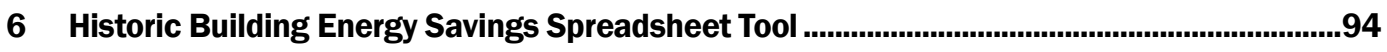

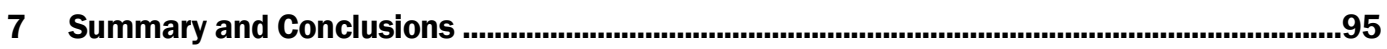

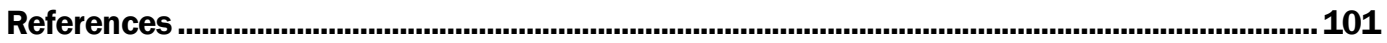

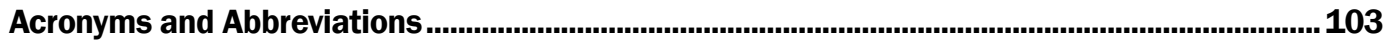

Report Documentation Page (SF 298) .............................................................................. 105 


\section{Tables and Figures}

\section{Tables}

ES1 Simple payback resulting from decreasing infiltration ....................................................... V

ES2 Simple payback resulting from improving wall insulation ..................................................... V

ES3 Simple payback resulting from improving roof/attic insulation ........................................... V

ES4 Simple payback resulting from replacing mechanical equipment..........................................vi

ES5 Simple payback resulting from replacing mechanical equipment controls...........................vi

ES6 Simple payback resulting from lighting retrofits ..................................................................vii

ES7 Simple payback resulting from PV panels retrofit ...................................................................vii

ES8 Simple payback resulting from improving ground floor insulation..........................................ii

ES9 Simple payback resulting from the use of skylighting ..............................................................ii

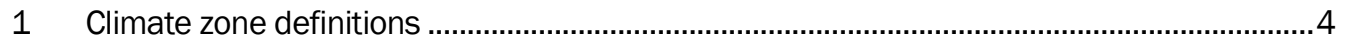

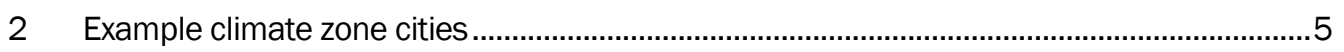

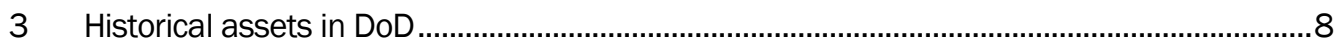

4 - Army Installations with over 1,000 historic facilities ..............................................................

5 - HQIIS database sorting results for six Midwest installations .............................................. 14

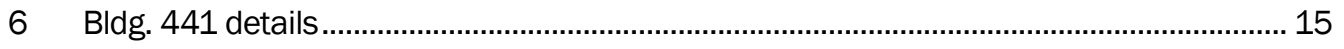

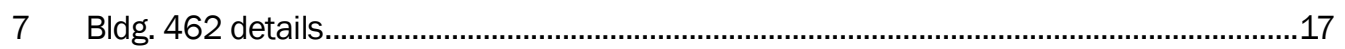

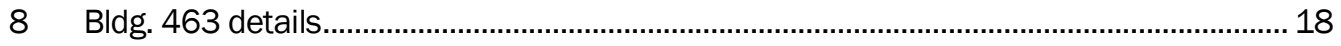

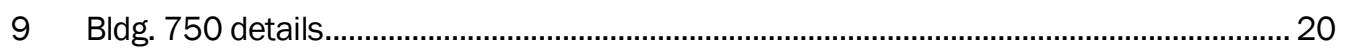

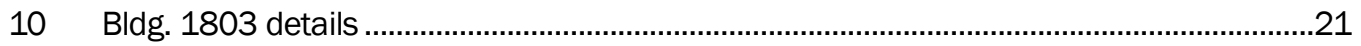

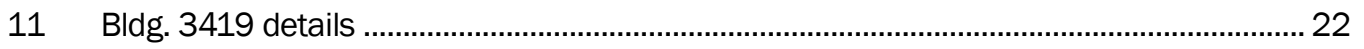

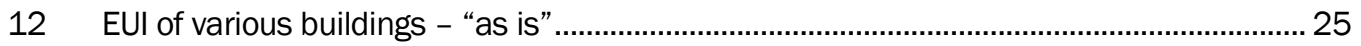

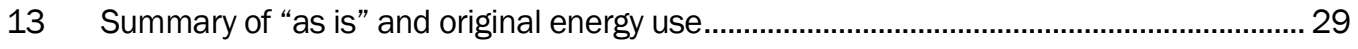

14 Bldg. 441, savings and payback summary, Climate Zone 1A (Miami, FL)..........................31

15 Bldg. 441, savings and payback summary, Climate Zone 2A (Houston, TX) ..................... 32

16 Bldg. 441, savings and payback summary, Climate Zone 2B (Phoenix, AZ) ..................... 32

17 Bldg. 441, savings and payback summary, Climate Zone 3A (Memphis, TN)................... 32

18 Bldg. 441, savings and payback summary, Climate Zone 3B (El Paso, TX) ....................... 32

19 Bldg. 441, savings and payback summary, Climate Zone 3C (San Francisco, CA) ............ 33

20 Bldg. 441, savings and payback summary, Climate Zone 4A (Baltimore, MD).................. 33

21 Bldg. 441, savings and payback summary, Climate Zone 4B (Albuquerque, NM) ............. 33

22 Bldg. 441, savings and payback summary, Climate Zone 4C (Seattle, WA)...................... 33

23 Bldg. 441, savings and payback summary, Climate Zone 5A (Chicago, IL) ........................ 34

24 Bldg. 441, savings and payback summary, Climate Zone 5B (Colorado Springs, C0) ...... 34

25 Bldg. 441, savings and payback summary, Climate Zone 6A (Burlington, VT) ................... 34

26 Bldg. 441, savings and payback summary, Climate Zone 6B (Helena, MT)...................... 34

27 Bldg. 441, savings and payback summary, Climate Zone 7A (Duluth, MN) ...................... 35 


\section{Tables}

Bldg. 441, savings and payback summary, Climate Zone 8A (Fairbanks, AK)................... 35

29 Bldg. 462, savings and payback summary, Climate Zone 1A (Miami, FL) .........................37

30 Bldg. 462, savings and payback summary, Climate Zone 2A (Houston, TX)........................37

31 Bldg. 462, savings and payback summary, Climate Zone 2B (Phoenix, AZ) ...................... 38

32 Bldg. 462, savings and payback summary, Climate Zone 3A (Memphis, TN) .................... 38

33 Bldg. 462, savings and payback summary, Climate Zone 3B (El Paso, TX) ........................ 38

34 Bldg. 462, savings and payback summary, Climate Zone 3C (San Francisco, CA) ............ 38

35 Bldg. 462, savings and payback summary, Climate Zone 4A (Baltimore, MD) .................. 39

36 Bldg. 462, savings and payback summary, Climate Zone 4B (Albuquerque, NM)............. 39

37 Bldg. 462, savings and payback summary, Climate Zone 4C (Seattle, WA) ...................... 39

38 Bldg. 462, savings and payback summary, Climate Zone 5A (Chicago, IL)........................ 39

39 Bldg. 462, savings and payback summary, Climate Zone 5B (Colorado Springs, CO) ...... 40

40 Bldg. 462, savings and payback summary, Climate Zone 6A (Burlington, VT) .................... 40

41 Bldg. 462, savings and payback summary, Climate Zone 6B (Helena, MT) ....................... 40

42 Bldg. 462, savings and payback summary, Climate Zone 7A (Duluth, MN)....................... 40

43 Bldg. 462, savings and payback summary, Climate Zone 8A (Fairbanks, AK) ....................41

44 Bldg. 463, savings and payback summary, Climate Zone 1A (Miami, FL) .......................... 44

45 Bldg. 463, savings and payback summary, Climate Zone 2A (Houston, TX)...................... 44

46 Bldg. 463, savings and payback summary, Climate Zone 2B (Phoenix, AZ) ...................... 44

47 Bldg. 463, savings and payback summary, Climate Zone 3A (Memphis, TN) ................... 44

48 Bldg. 463, savings and payback summary, Climate Zone 3B (El Paso, TX) ....................... 45

49 Bldg. 463, savings and payback summary, Climate Zone 3C (San Francisco, CA) ............ 45

50 Bldg. 463, savings and payback summary, Climate Zone 4A (Baltimore, MD) .................. 45

51 Bldg. 463, savings and payback summary, Climate Zone 4B (Albuquerque, NM)............ 45

52 Bldg. 463, savings and payback summary, Climate Zone 4C (Seattle, WA) ...................... 46

53 Bldg. 463, savings and payback summary, Climate Zone 5A (Chicago, IL)......................... 46

54 Bldg. 463, savings and payback summary, Climate Zone 5B (Colorado Springs, C0) ...... 46

55 Bldg. 463, savings and payback summary, Climate Zone 6A (Burlington, VT) ................... 46

56 Bldg. 463, savings and payback summary, Climate Zone 6B (Helena, MT) .........................47

57 Bldg. 463, savings and payback summary, Climate Zone 7A (Duluth, MN)........................47

58 Bldg. 463, savings and payback summary, Climate Zone 8A (Fairbanks, AK) ....................47

59 Bldg. 750, savings and payback summary, Climate Zone 1A (Miami, FL) .......................... 50

60 Bldg. 750, savings and payback summary, Climate Zone 2A (Houston, TX)........................51

61 Bldg. 750, savings and payback summary, Climate Zone 2B (Phoenix, AZ) .......................51

62 Bldg. 750, savings and payback summary, Climate Zone 3A (Memphis, TN) ....................51

63 Bldg. 750, savings and payback summary, Climate Zone 3B (El Paso, TX) .........................51

64 Bldg. 750, savings and payback summary, Climate Zone 3C (San Francisco, CA) ............ 52

65 Bldg. 750, savings and payback summary, Climate Zone 4A (Baltimore, MD) .................. 52

66 Bldg. 750, savings and payback summary, Climate Zone 4B (Albuquerque, NM)............ 52 


\section{Tables}

67

68

69

70

Bldg. 750, savings and payback summary, Climate Zone 4C (Seattle, WA) 52

Bldg. 750, savings and payback summary, Climate Zone 5A (Chicago, IL)........................ 53

Bldg. 750, savings and payback summary, Climate Zone 5B (Colorado Springs, CO) ...... 53

Bldg. 750, savings and payback summary, Climate Zone 6A (Burlington, VT) .................. 53

Bldg. 750, savings and payback summary, Climate Zone 6B (Helena, MT) ...................... 53

Bldg. 750, savings and payback summary, Climate Zone 7A (Duluth, MN)...................... 54

Bldg. 750, savings and payback summary, Climate Zone 8A (Fairbanks, AK) .................. 54

Bldg. 1803, savings and payback summary, Climate Zone 1A (Miami, FL) ....................... 58

Bldg. 463, savings and payback summary, Climate Zone 2A (Houston, TX)...................... 58

BIdg. 1803, savings and payback summary, Climate Zone 2B (Phoenix, AZ) ................... 58

Bldg. 463, savings and payback summary, Climate Zone 3A (Memphis, TN) ................... 58

BIdg. 1803, savings and payback summary, Climate Zone 3B (El Paso, TX).................... 59

Bldg. 1803, savings and payback summary, Climate Zone 3C (San Francisco, CA).......... 59

Bldg. 1803, savings and payback summary, Climate Zone 4A (Baltimore, MD)............... 59

Bldg. 1803, savings and payback summary, Climate Zone 4B (Albuquerque, NM) .......... 59

Bldg. 1803, savings and payback summary, Climate Zone 4C (Seattle, WA) ..................... 60

Bldg. 1803, savings and payback summary, Climate Zone 5A (Chicago, IL) ..................... 60

Bldg. 1803, savings and payback summary, Climate Zone 5B (Colorado Springs, C0).... 60

Bldg. 1803, savings and payback summary, Climate Zone 6A (Burlington, VT)................ 60

Bldg. 1803, savings and payback summary, Climate Zone 6B (Helena, MT).....................61

Bldg. 1803, savings and payback summary, Climate Zone 7A (Duluth, MN) ....................61

Bldg. 1803, savings and payback summary, Climate Zone 8A (Fairbanks, AK) .................61

Bldg. 3419, savings and payback summary, Climate Zone 1A (Miami, FL) ....................... 65

Bldg. 3419, savings and payback summary, Climate Zone 2A (Houston, TX).................... 65

BIdg. 3419, savings and payback summary, Climate Zone 2B (Phoenix, AZ)...................... 65

Bldg. 3419, savings and payback summary, Climate Zone 3A (Memphis, TN) ................. 65

Bldg. 3419, savings and payback summary, Climate Zone 3B (El Paso, TX) ..................... 66

Bldg. 3419, savings and payback summary, Climate Zone 3C (San Francisco, CA).......... 66

Bldg. 3419, savings and payback summary, Climate Zone 4A (Baltimore, MD) ................ 66

Bldg. 3419, savings and payback summary, Climate Zone 4B (Albuquerque, NM)........... 66

Bldg. 3419, savings and payback summary, Climate Zone 4C (Seattle, WA) ..................... 67

Bldg. 3419, savings and payback summary, Climate Zone 5A (Chicago, IL) ...................... 67

Bldg. 3419, savings and payback summary, Climate Zone 5B (Colorado Springs, C0) .... 67

Bldg. 3419, savings and payback summary, Climate Zone 6A (Burlington, VT) ................. 67

Bldg. 3419, savings and payback summary, Climate Zone 6B (Helena, MT) ..................... 68

Bldg. 3419, savings and payback summary, Climate Zone 7A (Duluth, MN)..................... 68

Bldg. 3419, savings and payback summary, Climate Zone 8A (Fairbanks, AK) ................. 68

Fort Bliss, Bldg. 1 details .................................................................................................. 71

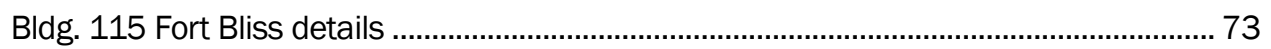




\section{Tables}

106 Fort Bliss Bldg. 1103, details ...........................................................................................74

107 Bldg. 1, Fort Bliss, savings and payback summary, Climate Zone 1A (Miami, FL) ............. 77

108 Bldg. 1, Fort Bliss, savings and payback summary, Climate Zone 2A (Houston, TX) ......... 77

109 Bldg. 1, Fort Bliss, savings and payback summary, Climate Zone 2B (Phoenix, AZ)......... 77

110 Bldg. 1, Fort Bliss, savings and payback summary, Climate Zone 3A (Memphis, TN) ....... 77

111 Bldg. 1, Fort Bliss, savings and payback summary, Climate Zone 3B (El Paso, TX).......... 78

112 Bldg. 1, Fort Bliss, savings and payback summary, Climate Zone 3C (San Francisco, CA) .......78

113 Bldg. 1, Fort Bliss, savings and payback summary, Climate Zone 4A (Baltimore, MD) ..... 78

114 Bldg. 1, Fort Bliss, savings and payback summary, Climate Zone 4B (Albuquerque, NM)........78

115 Bldg. 1, Fort Bliss, savings and payback summary, Climate Zone 4C (Seattle, WA).......... 79

116 Bldg. 1, Fort Bliss, savings and payback summary, Climate Zone 5A (Chicago, IL) ........... 79

117 Bldg. 1, Fort Bliss, savings and payback summary, Climate Zone 5B (Colorado Springs, CO)...... 79

118 Bldg. 1, Fort Bliss, savings and payback summary, Climate Zone 6A (Burlington, VT)...... 79

119 Bldg. 1, Fort Bliss, savings and payback summary, Climate Zone 6B (Helena, MT).......... 80

120 Bldg. 1, Fort Bliss, savings and payback summary, Climate Zone 7A (Duluth, MN) .......... 80

121 Bldg. 1, Fort Bliss, savings and payback summary, Climate Zone 8A (Fairbanks, AK) ...... 80

122 Bldg. 115 savings and payback summary, Climate Zone 1A (Miami, FL)............................ 83

123 Bldg. 115 savings and payback summary, Climate Zone 2A (Houston, TX)........................ 83

124 Bldg. 115 savings and payback summary, Climate Zone 2B (Phoenix, AZ) ........................ 83

125 Bldg. 115 savings and payback summary, Climate Zone 3A (Memphis, TN) ..................... 83

126 Bldg. 115 savings and payback summary, Climate Zone 3B (EI Paso, TX) ......................... 84

127 Bldg. 115 savings and payback summary, Climate Zone 3C (San Francisco, CA) ............. 84

128 Bldg. 115 savings and payback summary, Climate Zone 4A (Baltimore, MD) .................... 84

129 Bldg. 115 savings and payback summary, Climate Zone 4B (Albuquerque, NM).............. 84

130 Bldg. 115 savings and payback summary, Climate Zone 4C (Seattle, WA)........................ 84

131 Bldg. 115 savings and payback summary, Climate Zone 5A (Chicago, IL)......................... 85

132 Bldg. 115 savings and payback summary, Climate Zone 5B (Colorado Springs, CO) ....... 85

133 Bldg. 115 savings and payback summary, Climate Zone 6A (Burlington, VT) .................... 85

134 Bldg. 115 savings and payback summary, Climate Zone 6B (Helena, MT) ........................ 85

135 Bldg. 115 savings and payback summary, Climate Zone 7A (Duluth, MN)........................ 85

136 Bldg. 115 savings and payback summary, Climate Zone 8A (Fairbanks, AK) ..................... 86

137 Bldg. 1103 savings and payback summary, Climate Zone 1A (Miami, FL) ......................... 88

138 Bldg. 1103 savings and payback summary, Climate Zone 2A (Houston, TX) ...................... 88

139 Bldg. 1103 savings and payback summary, Climate Zone 2B (Phoenix, AZ)...................... 88

140 Bldg. 1103 savings and payback summary, Climate Zone 3A (Memphis, TN) ................... 89

141 Bldg. 1103 savings and payback summary, Climate Zone 3B (EI Paso, TX) ...................... 89

142 Bldg. 1103 savings and payback summary, Climate Zone 3C (San Francisco, CA)........... 89

143 Bldg. 1103 savings and payback summary, Climate Zone 4A (Baltimore, MD) ................. 89

144 Bldg. 1103 savings and payback summary, Climate Zone 4B (Albuquerque, NM) ........... 90 


\section{Tables}

145 Bldg. 1103 savings and payback summary, Climate Zone 4C (Seattle, WA) ...................... 90

146 Bldg. 1103 savings and payback summary, Climate Zone 5A (Chicago, IL) .......................90

147 Bldg. 1103 savings and payback summary, Climate Zone 5B (Colorado Springs, CO)..... 90

148 Bldg. 1103 savings and payback summary, Climate Zone 6A (Burlington, VT)..................91

149 Bldg. 1103 savings and payback summary, Climate Zone 6B (Helena, MT) .......................91

150 Bldg. 1103 savings and payback summary, Climate Zone 7A (Duluth, MN) ......................91

151 Bldg. 1103 savings and payback summary, Climate Zone 8A (Fairbanks, AK) ...................91

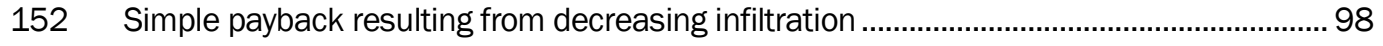

153 Simple payback resulting from improving wall insulation .....................................................98

154 Simple payback resulting from improving roof/attic insulation ......................................... 98

155 Simple payback resulting from replacing mechanical equipment......................................99

156 Simple payback resulting from replacing mechanical equipment controls......................... 99

157 Simple payback resulting from lighting retrofits ................................................................100

158 Simple payback resulting from PV panels retrofit ............................................................. 100

159 Simple payback resulting from improving ground floor insulation....................................... 100

160 Simple payback resulting from the use of skylighting .......................................................100

\section{Figures}

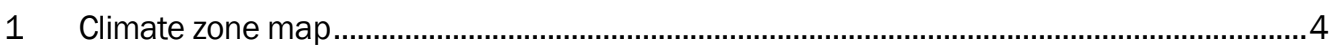

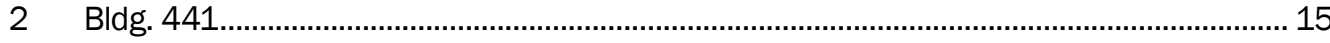

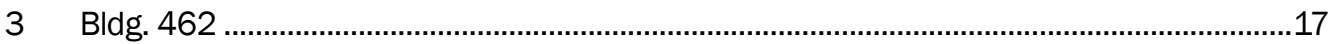

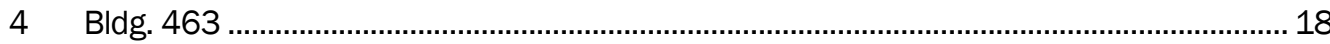

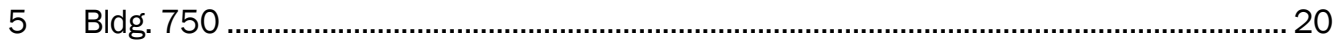

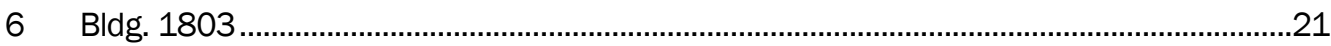

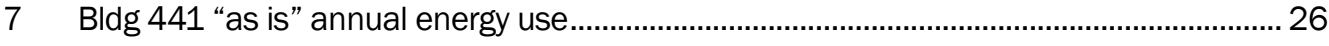

8 Bldg. 441, annual cost savings resulting from EEM “Reduce Infiltration," by climate zone ......35

9 Bldg. 441, simple payback resulting from EEM “Reduce Infiltration,” by climate zone..... 35

10 Bldg. 441, annual cost savings resulting from EEM “Wall Insulation," by climate zone.... 35

11 Bldg. 441, simple payback resulting from EEM “Wall Insulation," by climate zone ........... 35

12 Bldg. 441, annual cost savings resulting from EEM "Roof/Attic Insulation," by climate zone....... 36

13 Bldg. 441, simple payback resulting from EEM “Roof/Attic Insulation,” by climate zone......36

14 Bldg. 441, annual cost savings resulting from EEM "Replace Mechanical Equipment Controls EEM," by climate zone .......................................................................................... 36

15 Bldg. 441, simple payback resulting from EEM “Replace Mechanical Equipment Controls EEM," by climate zone ............................................................................................. 36

16 Bldg. 462, annual cost savings resulting from EEM "Reduce Infiltration," by climate zone......41

17 Bldg. 462, simple payback resulting from EEM "Reduce Infiltration," by climate zone .....41

18 Bldg. 462, annual cost savings resulting from EEM "Lighting Controls," by climate zone.....41

19 Bldg. 462, simple payback resulting from EEM “Lighting Controls,” by climate zone ........41 


\section{Figures}

20 Bldg. 462, annual cost savings resulting from EEM “Roof/Attic Insulation," by climate zone

Bldg. 462, simple payback resulting from EEM “Roof/Attic Insulation," by climate zone......42

Bldg. 462, annual cost savings resulting from EEM "Replace Mechanical Equipment EEM," by climate zone.

Bldg. 462, simple payback resulting from EEM “Replace Mechanical Equipment EEM," by climate zone.

Bldg. 462, annual cost savings resulting from EEM "Replace Mechanical Equipment Controls EEM," by climate zone.

Bldg. 462, simple payback resulting from EEM "Replace Mechanical Equipment Controls EEM," by climate zone.

Bldg. 463, annual cost savings resulting from EEM “Reduce Infiltration," by climate zone......48

Bldg. 463, simple payback resulting from EEM "Reduce Infiltration," by climate zone .... 48

Bldg. 463, simple payback resulting from EEM “Lighting Controls," by climate zone ....... 48

Bldg. 463, annual cost savings resulting from EEM "Roof/Attic Insulation," by

climate zone

Bldg. 463, simple payback resulting from EEM “Roof/Attic Insulation," by climate zone......48

Bldg. 463, annual cost savings resulting from EEM "Replace Mechanical Equipment

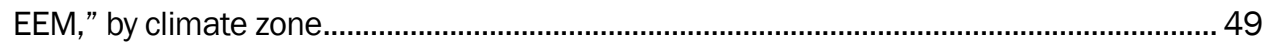

33 Bldg. 463, simple payback resulting from EEM "Replace Mechanical Equipment

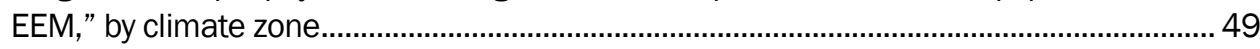

34 Bldg. 463, annual cost savings resulting from EEM "Replace Mechanical Equipment Controls EEM," by climate zone .................................................................................... 49

35 Bldg. 463, simple payback resulting from EEM "Replace Mechanical Equipment

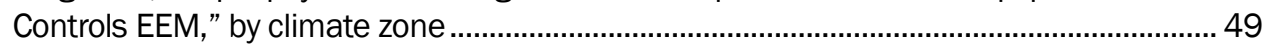

36 Bldg. 750, annual cost savings resulting from EEM “Reduce Infiltration," by climate zone......54

37 Bldg. 750, simple payback resulting from EEM “Reduce Infiltration," by climate zone .... 54

38 Bldg. 750, annual cost savings resulting from EEM “Lighting Controls," by climate zone .....55

39 Bldg. 750, simple payback resulting from EEM “Lighting Controls," by climate zone ....... 55

40 Bldg. 750, annual cost savings resulting from EEM “Roof/Attic Insulation,” by

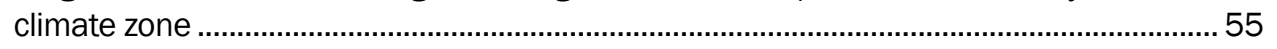

41 Bldg. 750, simple payback resulting from EEM “Roof/Attic Insulation," by climate zone..........55

42 Bldg. 750, annual cost savings resulting from EEM “Replace Chiller EEM,” by

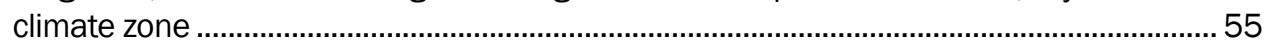

43 Bldg. 750, simple payback resulting from EEM “Replace Chiller EEM,” by climate zone ......55

44 Bldg. 750, annual cost savings resulting from EEM “Replace Mechanical Equipment Controls EEM," by climate zone ......................................................................................... 56

45 Bldg. 750, simple payback resulting from EEM “Replace Mechanical Equipment Controls EEM," by climate zone ..................................................................................... 56

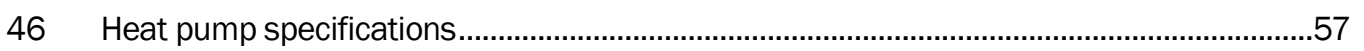

47 Bldg. 1803, annual cost savings resulting from EEM “Reduce Infiltration,” by climate zone ....... 62 


\section{Figures}

48 Bldg. 1803, simple payback resulting from EEM "Reduce Infiltration," by climate zone.......62

49 Bldg. 1803, annual cost savings resulting from EEM “Lighting Controls," by climate zone ......62

50 Bldg. 1803, simple payback resulting from EEM "Lighting Controls," by climate zone ..... 62

51 Bldg. 1803, annual cost savings resulting from EEM "Roof/Attic Insulation," by

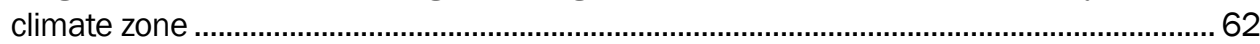

52 Bldg. 1803, simple payback resulting from EEM “Roof/Attic Insulation," by climate

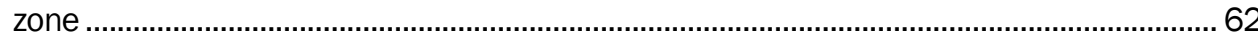

53 Bldg. 1803, annual cost savings resulting from EEM "Replace Mechanical Equipment EEM," by climate zone 63

54 Bldg. 1803, simple payback resulting from EEM “Replace Mechanical Equipment

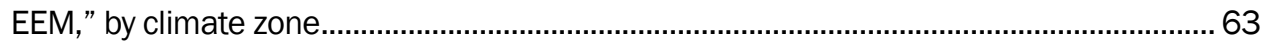

55 Bldg. 1803, annual cost savings resulting from EEM "Replace Mechanical Equipment Controls EEM," by climate zone

Bldg. 1803, simple payback resulting from EEM “Replace Mechanical Equipment Controls EEM," by climate zone

Bldg. 3419, annual cost savings resulting from EEM “Reduce Infiltration,” by climate zone........ 68 BIdg. 3419, simple payback resulting from EEM "Reduce Infiltration," by climate zone .......68 Bldg. 3419, annual cost savings resulting from EEM “Lighting Controls,” by climate zone.......69 Bldg. 3419, simple payback resulting from EEM "Lighting Controls," by climate zone ..... 69 BIdg. 3419, annual cost savings resulting from EEM "PV Cells," by climate zone. Bldg. 3419, simple payback resulting from EEM "PV Cells," by climate zone.

63 Bldg. 3419, annual cost savings resulting from EEM “Replace Mechanical Equipment EEM," by climate zone

Bldg. 3419, simple payback resulting from EEM “Replace Mechanical Equipment EEM," by climate zone.

Bldg. 3419, annual cost savings resulting from EEM “Replace Mechanical Equipment Controls EEM," by climate zone.

Bldg. 3419, simple payback resulting from EEM "Replace Mechanical Equipment Controls EEM," by climate zone ..................................................................................... 70

71 Bldg. 1, Fort Bliss, annual cost savings resulting from EEM "Reduce Infiltration," by climate zone

Bldg. 1, Fort Bliss, annual cost savings resulting from EEM “High Efficiency Lighting," by climate zone

Bldg. 1, Fort Bliss, simple payback resulting from EEM “High Efficiency Lighting," by climate zone

BIdg. 1, Fort Bliss, annual cost savings resulting from EEM “Wall Insulation," by 


\section{Figures}

76 Bldg. 1, Fort Bliss, simple payback resulting from EEM “Wall Insulation," by climate zone.......81

77 Bldg. 1, Fort Bliss, annual cost savings resulting from EEM “Night Setback of Thermostat Temperatures EEM," by climate zone

78 Bldg. 1, Fort Bliss, simple payback resulting from EEM "Night Setback of Thermostat Temperatures EEM," by climate zone ................................................................................

79 Bldg. 1, Fort Bliss, total EEM payback, by climate zone .................................................... 82

80 Bldg. 1, Fort Bliss, lighting power density specifications.................................................... 82

81 Bldg. 115, Fort Bliss, annual cost savings resulting from EEM "Reduce Infiltration,"

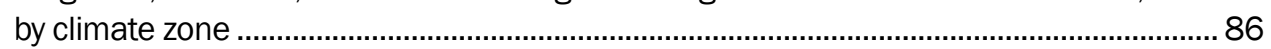

82 Bldg. 115, Fort Bliss, simple payback resulting from EEM “Reduce Infiltration," by

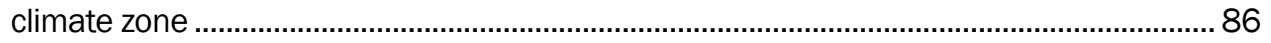

83 Bldg. 115, Fort Bliss, annual cost savings resulting from EEM “High Efficiency

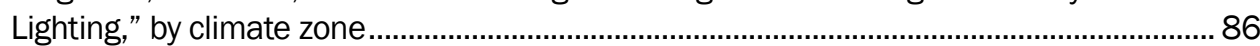

84 Bldg. 115, Fort Bliss, simple payback resulting from EEM “High Efficiency Lighting,"

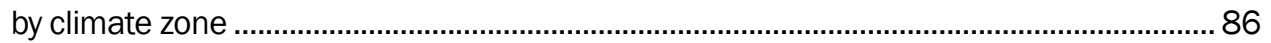

85 Bldg. 115, Fort Bliss, annual cost savings resulting from EEM "Night Setback of Thermostat Temperatures EEM," by climate zone.

86 Bldg. 115, Fort Bliss, simple payback resulting from EEM “Night Setback of Thermostat Temperatures EEM," by climate zone ...................................................................87

87 Bldg. 115, Fort Bliss, total EEM payback, by climate zone ................................................8

88 Bldg. 115, Fort Bliss, annual cost savings resulting from EEM "Reduce Infiltration,"

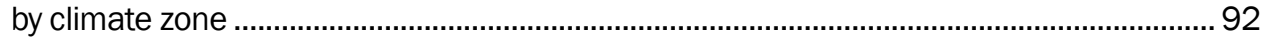

89 Bldg. 115, Fort Bliss, simple payback resulting from EEM "Reduce Infiltration," by climate zone

90 Bldg. 115, Fort Bliss, annual cost savings resulting from EEM “Use Condensing Furnaces," by climate zone

91 Bldg. 115, Fort Bliss, simple payback resulting from EEM “Use Condensing Furnaces," by climate zone

92 Bldg. 115, Fort Bliss, annual cost savings resulting from EEM "Wall Insulation EEM,"

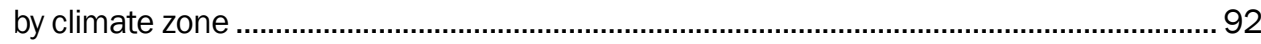

93 Bldg. 115, Fort Bliss, simple payback resulting from EEM "Wall Insulation EEM," by climate zone

94 Bldg. 115, Fort Bliss, annual cost savings resulting from EEM “Ground Floor Insulation EEM," by climate zone

95 Bldg. 115, Fort Bliss, simple payback resulting from EEM “Ground Floor Insulation EEM," by climate zone.

96 Bldg. 115, Fort Bliss, annual cost savings resulting from EEM “Use Skylighting EEM," by climate zone

97 Bldg. 115, Fort Bliss, simple payback resulting from EEM “Use Skylighting EEM," by climate zone 93 


\section{Preface}

This study was conducted for the Office of the Assistant Secretary of Defense for Energy, Installations, and Environment (OASD[EI\&E]) under the Legacy Resource Management Program, Project 15-777, "Identify Life Cycle Cost Benefits of Energy Efficiency in Historic Buildings." The technical monitor was Michelle Volkema, DoD Deputy Federal Preservation Officer, OASD(EI\&E).

The work was performed by the Energy Branch (CFE) of the Facilities Division (CF), U.S. Army Engineer Research and Development Center, Construction Engineering Research Laboratory (ERDC-CERL). Thanks are owed to the Legacy program for funding this research. Special credit is bestowed upon Adam Smith and Megan Tooker, of the Cultural Resources group at ERDC-CERL, for their assistance in analyzing the types and number of historic buildings within DoD and the selection of buildings to model. Great appreciation is owed to the Fort Sill, OK, personnel who generously assisted with these tasks. At the time of publication, Gisselle Rodriguez was Acting Chief, CEERD-CFE; L. Michelle J. Hanson was Acting Chief, CEERD-CF; and Kurt Kinnevan, CEERD-CZT was the Technical Director for Installations. The Deputy Director of ERDC-CERL was Dr. Kirankumar V. Topudurti and the Director was Dr. Ilker R. Adiguzel.

COL Bryan S. Green was Commander of ERDC, and Dr. Jeffery P. Holland was the Director. 


\section{Introduction}

\subsection{Background}

The U.S. Department of Defense (DoD) is required by several executive orders (EO 13693 [2015], EO 13423 [2007], EO 13123 [1999]) and other laws and policies (EPACT 2005, EISA 2007, Army Directive 2014-02 [SA 2014]) to decrease energy consumption and increase the use of renewable energy where life cycle cost effective. Specifically, the Army is required by law to reduce overall facility energy use by $30 \%$ by 2015 and to eliminate fossil fuel use in new and renovated facilities by 2030.

Currently, over 30\% of DoD's buildings are over 50 years old. By 2025, DoD real property more than 50 years old will increase to nearly $70 \%$, and will become eligible for National Register of Historic Places evaluation. However, the energy efficiency measures (EEMs) commonly taken to make required energy efficiency improvements in buildings are often difficult or impossible to implement on historic buildings because they involve making changes to the buildings that violate the requirements of the Historical Preservation Act (HPA). For example, installation of solar panels on a roof commonly alters the building's historic appearance.

In such cases, energy efficiency studies must meet dual (and sometimes conflicting) requirements, to enable historic buildings to conserve energy while preserving their historic and cultural nature and appearance. This work was undertaken to help military installations meet those requirements in historic buildings on DoD sites.

\subsection{Objectives}

The objective of this work was to help military installations meet energy efficiency and HPA requirements in onsite historic buildings by: (1) assessing all factors affecting energy use in historic buildings, (2) analyzing the effects of EEMs on energy use, and (3) prioritizing and optimizing the use of combinations of EEMs in typical building types in various climate zones across the United States. 


\subsection{Approach}

This work reviewed the DoD stock of buildings that has either been declared historical or deemed eligible for historic building status. To generate findings applicable to this large number of many types of historic (or potentially historical) buildings, this analysis selected a representative set of similar historic buildings. Computer models of the selected buildings were developed using the eQUEST building energy simulation software tool. Selected EEMs were evaluated for their potential to yield energy and cost savings, while maintaining compliance with the HPA, which is intended to preserve historical and archaeological sites in the United States of America. The results of these analyses were then extrapolated to similar buildings in other climate zones, and then summarized to provide a guide on the use of various EEMs (or combinations of EEMs) typically applicable to various historic building types in different U.S. climate zones. 


\section{Energy Terms}

\subsection{Heating and cooling degree days}

"Degree days" are essentially a simplified representation of outside air temperature data. They are widely used in the energy industry for calculations relating to the effect of outside air temperature on building energy consumption.

"Heating degree days," or "HDD," are a measure of how much (in degrees), and for how long (in days), outside air temperature was lower than a specific "base temperature" (or "balance point"). They are used in calculations relating to the energy consumption required to heat buildings.

"Cooling Degree Days," or "CDD," are a measure of how much (in degrees), and for how long (in days), outside air temperature was higher than a specific base temperature. They are used for calculations relating to the energy consumption required to cool buildings.

\subsection{Climate zones}

Climate zones represent geographical areas of the United States with various heating and cooling needs (Figure 1). These needs are measured in the number of Heating Degree Days and Cooling Degree Days an area has. There are eight different climate zones in the United States (Table 1). The eight climate zones are further divided based on the moisture of the area, for a total of 15 different zone divisions. The three divisions are A (moist), $\mathrm{B}$ (dry), and C (marine). Table 2 lists an example city for each of the 15 different zone divisions. 
Figure 1. Climate zone map.

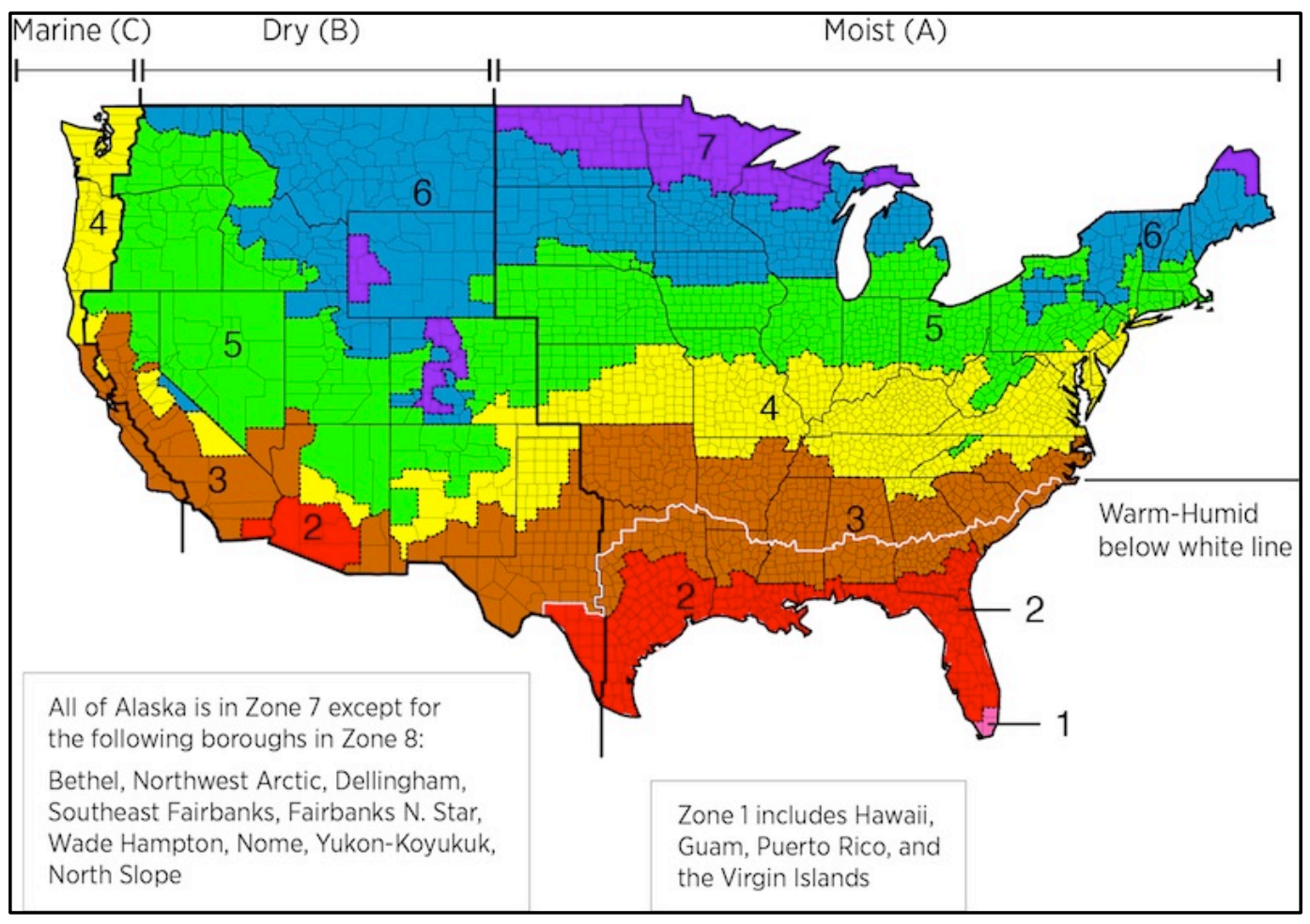

Table 1. Climate zone definitions.

\begin{tabular}{|c|c|c|}
\hline \multirow[b]{2}{*}{ Zone Number } & \multicolumn{2}{|c|}{ Thermal Criteria } \\
\hline & IP Units* & SI Units* \\
\hline 1 & $9000<\mathrm{CDD} 50^{\circ} \mathrm{F}$ & $5000<\mathrm{CDD} 10^{\circ} \mathrm{C}$ \\
\hline 2 & $6300<\mathrm{CDD}^{\circ} 0^{\circ} \mathrm{F}<=9000$ & $3500<\mathrm{CDD} 10^{\circ} \mathrm{C}<=5000$ \\
\hline $3 \mathrm{~A}$ and $3 \mathrm{~B}$ & $\begin{array}{l}4500<\mathrm{CDD}^{\circ} 0^{\circ} \mathrm{F}<=6300 \\
\text { and } \\
\mathrm{HDD} 65^{\circ} \mathrm{F}<=5400\end{array}$ & $\begin{array}{l}2500<\mathrm{CDD} 10^{\circ} \mathrm{C}<=3500 \\
\text { and } \\
\mathrm{HDD} 18^{\circ} \mathrm{C}<=3000\end{array}$ \\
\hline $4 \mathrm{~A}$ and $4 \mathrm{~B}$ & $\begin{array}{l}\mathrm{CDD}^{\circ} 0^{\circ} \mathrm{F}<=4500 \\
\text { and } \\
\mathrm{HDD}^{\circ} 5^{\circ} \mathrm{F}<=5400\end{array}$ & $\begin{array}{l}\mathrm{CDD} 10^{\circ} \mathrm{C}<=2500 \\
\text { and } \\
\operatorname{HDD} 18^{\circ} \mathrm{C}<=3000\end{array}$ \\
\hline $3 C$ & $\mathrm{HDD}^{\circ} 5^{\circ} \mathrm{F}<=3600$ & $\mathrm{HDD} 18^{\circ} \mathrm{C}<=2000$ \\
\hline $4 \mathrm{C}$ & $3600<\mathrm{HDD}^{\circ} 5^{\circ} \mathrm{F}<=5400$ & $2000<\mathrm{HDD} 18^{\circ} \mathrm{C}<=3000$ \\
\hline 5 & $5400<\mathrm{HDD}^{\circ} 5^{\circ} \mathrm{F}<=7200$ & $3000<\mathrm{HDD} 18^{\circ} \mathrm{C}<=4000$ \\
\hline 6 & $7200<\mathrm{HDD}^{\circ} 5^{\circ} \mathrm{F}<=9000$ & $4000<\mathrm{HDD} 18^{\circ} \mathrm{C}<=5000$ \\
\hline 7 & $9000<\mathrm{HDD}^{\circ} 5^{\circ} \mathrm{F}<=12600$ & $5000<\mathrm{HDD} 18^{\circ} \mathrm{C}<=7000$ \\
\hline 8 & $12600<\mathrm{HDD}^{\prime} 5^{\circ} \mathrm{F}$ & $7000<\mathrm{HDD} 18^{\circ} \mathrm{C}$ \\
\hline
\end{tabular}


Table 2. Example climate zone cities.

\begin{tabular}{|c|l|}
\hline Climate Zone & Example City, State \\
\hline 1A & Miami, FL \\
\hline 2A & Houston, TX \\
\hline 2B & Phoenix, AZ \\
\hline 3A & Memphis, TN \\
\hline 3B & El Paso, TX \\
\hline 3C & San Francisco, CA \\
\hline 4A & Baltimore, MD \\
\hline 4B & Albuquerque, NM \\
\hline 4C & Seattle, WA \\
\hline 5A & Chicago, IL \\
\hline 5B & Colorado Springs, CO \\
\hline 6A & Burlington, VT \\
\hline 6B & Helena, MT \\
\hline 7A & Duluth, MN \\
\hline 8A & Fairbanks, AK \\
\hline & \\
\hline
\end{tabular}

\section{3 eQUEST - The Quick Energy Simulation Tool}

\subsubsection{Overview}

The eQUEST building energy simulation tool (Hirsch 2010), which is based on DOE-2 (Hirsch 2016), has undergone decades of development. DOE-2 was originally developed by the Department of Energy. The eQUEST graphical interface allows users with limited simulation experience to quickly develop three-dimensional simulation models of a particular building design. These simulations incorporate building location, orientation, wall/roof construction, window properties, as well as Heating, Ventilating, and Air-Conditioning (HVAC) systems, daylighting and various control strategies, along with the ability to evaluate design options for any single or combination of energy conservation measure(s).

\subsubsection{Inputs}

Initial input is done via the "wizard," which is broken into a "Schematic Design Wizard" and a "Design Development Wizard." The model's complexity can begin with a simple box and single-zone to the actual design, with the ability to import inputs from AutoCAD (* ${ }^{*} \mathrm{dwg}$ ) files with complex 
occupancy schedules and rate schedules. Although the use of default values allow for quick development of building models, the use of too many default values without verification can produces unreliable results.

\subsubsection{Outputs}

The general outputs from eQUEST include annual energy consumption and associated costs for a particular building design. Included in the extensive output reports are:

- Summary of Inputs (schedules, building construction characteristics, summary of load components and peak loads)

- HVAC System Characteristics (input characteristics, system size, runtimes, capacity, and air/fluid flow)

- Hourly Reports from user-specified building components.

\subsection{Btus, therms, and MMBtus}

A British Thermal Unit (Btu) is a unit of work, equivalent to the amount of work needed to raise the temperature of a pound of water by a single degree Fahrenheit. As it is not an SI unit, it is only commonly used in North America, where the energy content of fuels is often given in Btus. This measure is used to express the energy use of buildings in terms of Btu/year. This unit is most commonly used when describing energy associated with heating. A therm is equivalent to 100,000 Btus. An MMBtu is 1,000,000 Btus.

\subsection{Watts, kilowatts (kW), and kilowatt-hour (kWh)}

A kilowatt is a unit of power used most commonly to describe instantaneous electricity use. $\mathrm{A} \mathrm{kW}$ is equivalent to 1,000 watts. $\mathrm{A} \mathrm{kWh}$ is a unit of energy, which is the integrated power use over time. For example if a device uses 10 $\mathrm{kW}$ of power for 1 hour then 10kWh of energy has been consumed.

\subsection{Footcandles and lumens}

A footcandle (abbreviated $\mathrm{fc}, \mathrm{lm} / \mathrm{ft}^{2}$, or sometimes $\mathrm{ft}-\mathrm{c}$ ) is a non-SI unit of illuminance or light intensity. The name "footcandle" conveys "the illuminance cast on a surface by a one-candle source $1 \mathrm{ft}$ away."

The unit is defined as the amount of illumination the inside surface of a 1 - $\mathrm{ft}$ radius sphere would receive if there were a uniform point source of 
one candela in the exact center of the sphere. Alternatively, it can be defined as the illuminance on a $1-\mathrm{ft}^{2}$ surface of which there is a uniformly distributed flux of 1 lumen. Thus 1 footcandle is equal to 1 lumen/ $\mathrm{ft}^{2}$, or approximately 10.764 lux.

\subsection{Economizer}

There are a variety of "economizer" types and modes of operation. As its name implies, the function of the economizer is to "economize" or save on cooling costs. Economizers discussed in this report refer to the introduction of outside air into the building when its energy content is less that the return air from the building (i.e., "free cooling" using outside air rather than mechanical cooling”). 


\section{DoD Stock of Historic and Potentially Historic Buildings}

The first phase of this project involved determining the types and number of historic buildings in DoD (Table 3). The purpose of this was to target the two most prevalent building types so the resulting Energy Conservation Measures (ECMs) would have the widest potential application. Table 3 lists the results of a query of the DoD Real Property Assets Database (RPAD). The query criteria were:

- Include Services (exclude Washington Headquarters Services [WHS])

- Include the United States and its Territories (exclude Foreign assets)

- Include Federal assets (exclude Army Designated State Sites)

- Include Buildings and Structures (exclude Linear Structures and Land)

- Exclude assets with Interest Type of Lease

- Exclude Historic Status Code = Department of Natural Resources (DNR)

- Exclude Disposed Assets (Assets with a Disposal Completion Date).

For purposes of this report:

- The term "All Assets" is defined as all DoD real property assets regardless of/including all historic status code (HSC), i.e., historic and nonhistoric assets (including buildings and structures).

- The term "Historic Assets" is defined as real property assets eligible for listing or listed in the National Register of Historic Places (NRHP).

The data in Table 3 indicate that, of the four Service Branches, the Army has the most historic buildings, in fact more than 50\% of DoD's historic building inventory. Because of this, the Army historic building stock was investigated further. Data drawn from the "Real Property Summary Installation and Site Statistics for Fiscal Year 2016 Quarter 1" (also known as the "Army Green Book") indicate that there are 12 Army installations with more than 1000 historic facilities (Table 4).

Table 3. Historical assets in DoD.

\begin{tabular}{|l|r|c|c|}
\hline \multicolumn{1}{|c|}{ Service Branch } & All Assets & Historic Assets & All Assets 40-49 Years Old \\
\hline Army & 190,512 & 36,245 & 11,893 \\
\hline Navy & 77,615 & 14,458 & 8,789 \\
\hline U.S. Marine Corps (USMC) & 36,901 & 4,618 & 2,505 \\
\hline Air Force & 71,784 & 5,465 & 6,587 \\
\hline DoD & 376,812 & 60,786 & 29,774 \\
\hline
\end{tabular}


Table 4 - Army Installations with over 1,000 historic facilities.

\begin{tabular}{|l|l|c|}
\hline Installation & State & Number of Historic Facilities \\
\hline Joint Base Lewis-McChord & Washington & 3850 \\
\hline Letterkenny Army Depot & Pennsylvania & 2838 \\
\hline McAlester Army Ammunition Plant & Oklahoma & 2156 \\
\hline Fort Bragg & North Carolina & 2084 \\
\hline Tooele Army Depot & Utah & 1985 \\
\hline Fort Hood & Texas & 1833 \\
\hline Pueblo Chemical Depot & Colorado & 1546 \\
\hline Milan Army Ammunition Plant & Tennessee & 1515 \\
\hline Anniston Army Depot & Alabama & 1383 \\
\hline White Sands Missile Range & New Mexico & 1174 \\
\hline Fort Bliss & Texas & 1129 \\
\hline Blue Grass Army Depot & Kentucky & 1030 \\
\hline
\end{tabular}

While this count of "historic facilities" does not reflect the exact number of historic buildings (a facility can be something other than a building), it does reveal the relative number of historic buildings because the majority of facilities are buildings.

\subsection{Most prevalent building types}

Based on the experiences of CERL's Cultural Resources Branch, the most common building types are (ordered by prevalence):

1. Barracks

2. Hangars

3. Administrative buildings.

\subsubsection{Barracks}

While barracks is the number one building type, the majority of barracks were built during the Cold War (1946-1975). Most of the pre-1946 barracks are now used as administrative buildings. This is a consequence of the space currently required per soldier, and the difficulty to modify these historic structures to meet modern barracks space requirements.

Any barracks built DoD-wide during the "cold war era" have a Program Comment in place that basically states that any changes and modifications to these buildings do not require any State Historic Preservation Office (SHPO) consultation or have a need to meet any Federal preservation 
standards. Therefore, they are not of interest to this project and were not considered for modeling and analysis.

Also, the Navy did not have many pre-WWII* barracks. In that time, Navy sailors were generally either sheltered on the ship, or were on leave so the Navy had no need to billet sailors when not on a ship. Most Marine Corps barracks are now used as administrative buildings/office space as well.

\subsubsection{Hangars}

There are probably four to eight hangars on every airfield, whether or not they are historic. There are also good examples at Pensacola (and Randolph) of these hangars being used as a Post Exchanges (PXs), Gymnasiums, and administrative buildings.

\subsubsection{Administrative facilities}

There are many different styles and ages of administrative facilities with a variety of historic statuses (eligible, individually eligible, and not eligible). Pre-1946 barracks are mostly used as administrative buildings now and are almost all are historic. A variety of construction materials were used (brick, stone, wood, and concrete). The construction materials used also varied across the services. Most historic hospital buildings are also now used as administrative buildings as well.

\subsubsection{Summary}

This preliminary characterization of DoD buildings has revealed several general findings:

1. Old barracks (1946-1975) are unlikely to ever be designated as historic buildings.

2. Newer barracks (built after 1975) are not historic buildings due their age.

3. Nearly all pre-1946 barracks are historic buildings and are now administrative buildings.

Based on these findings, information was gathered from several candidate installations where the project team had previously done work.

${ }^{*}$ WWII = World War II; WWI = World War I 


\subsubsection{Army}

Fort Knox, KY, has buildings dating from the Interwar period. The buildings here were mostly brick, and multistoried. The team is familiar with eight of these buildings and the hospital (which is now used for administrative functions as well). With 4,602 HDD and 1,421 CDD, the climate at Fort Knox has a good mix of heating and cooling needs.

Fort Leavenworth, KS, has buildings dating from the pre-Civil War to Interwar periods. These historic buildings are constructed of a mixture of wood, brick, and stone. The team is familiar with approximately nine of these buildings. With 5,177 HDD, 1,590 CDD, the climate at Fort Leavenworth has a good mix of heating and cooling needs.

Fort Riley, KS, has buildings dating from the Civil War to the Interwar period, representing a mix of wood, brick, and stone construction. Fort Riley has 5,267 HDD and 1,843 CDD.

Fort Sill, OK, has buildings dating from the Civil War to the Interwar period, representing a mix of wood, brick, and stone. Fort Sill has 3,523 HDD and 2,831 CDD.

Fort Benning, GA, has 2,643 HDD, 2,242 CDD.

Fort Bliss, TX, has buildings dating from the 1880 os to the Interwar period, the majority of which are stucco over wood. Fort Bliss has 2,802 HDD and 2,568 CDD.

Fort Huachuca has buildings dating from 1880 to the Interwar period, all of which are wood barracks from pre-1946, except for one remaining stucco (maybe over terracotta) building.

Fort Drum, NY, has no remaining pre-WWII barracks or administrative buildings,

\subsubsection{Navy}

Pensacola, FL, has buildings dating from WWI to the Interwar period, principally hangars and administrative buildings. (Pensacola took over a former Army fort and the barracks are now in Navy use.) 
Jacksonville, FL, has buildings (hangars) dating from WWII.

The Norfolk, VA, Naval Base has buildings dating from the 1890 os to the Interwar period, principally hangars and administrative buildings.

The Portsmouth, ME, Naval Shipyard has buildings dating from the $19^{\text {th }}$ century, consisting of former industrial space now used as administrative offices.

The Norfolk, VA, Naval Shipyard has buildings dating mostly from the $19^{\text {th }}$ century, consisting of former industrial space now used as administrative offices.

Naval Base San Diego has buildings (administrative buildings and hangars) dating from the Interwar period.

\subsubsection{Marines}

Quantico, VA, has buildings dating from the Interwar period, including brick multistory Interwar barracks now used as administrative buildings, and a few remaining hangars (the oldest of which is now a gymnasium).

Neither Camp Pendleton, CA, nor Camp Lejeune, NC, have any historic buildings.

Parris Island, SC, has buildings dating from the 1880 os to WWI, most of which are old Navy industrial buildings now used as administrative buildings.

\subsubsection{Air Force}

Much of the historic infrastructure at Air Force installations consists of buildings that remain from former Army Airfields. The Cold War Air Force bases, built in 1950s, are mostly concrete block buildings.

Fort Sam Houston, TX, has buildings dating from the Civil War to the Interwar period. The Air Force base, which was formerly an Army installation, now contains a variety of wood and brick administrative buildings.

Francis E. Warren Air Force Base (AFB), WY has buildings dating from the 1880 os to the Interwar period. The Air Force base, which was formerly an Army installation, now contains brick administrative buildings 
Randolph AFB, TX has buildings dating from the Interwar period. The Air Force base was formerly an Army Air Corps base.

Maxwell-Gunter AFB, AL has buildings dating from the Interwar period. The Air Force base was formerly an Army Air Corps base.

\subsubsection{The Selection}

Because of the large number of historic buildings in the Army and the project team's familiarity with Army installations, the selection process focused on Army installations. Another factor considered was the number and variety of building construction methods - because the types of EEMs possible depend on the construction method and materials used. The desirable factors considered include:

- active Army installation

- significant heating and cooling needs (based on climate)

- significant number of buildings designated as eligible for historic status

- non-unique facilities.

Based on these factors, facilities such as warehouses and vehicle maintenance facilities were eliminated from consideration since they are rarely cooled. Also, while most installations have a historic church, they are used intermittently and are typically unique.

\subsection{Selection of an Army installation}

The next step in selecting the buildings to be studied was to identify Army installations that had the type of historic buildings of interest. The Headquarters Installation Information System (HQIIS) database was used to develop a list of potential sites to visit. This Army database includes a category code for the historical status of an item. Items not listed as buildings were eliminated from consideration. The list was further sorted to exclude buildings less than 5,000 $\mathrm{ft}^{2}$ in size. Installations known to CERL's cultural resources people and were relatively close to CERL were searched and a table of prevalent building types was constructed (Table 5). 
Table 5 - HQIIS database sorting results for six Midwest installations.

\begin{tabular}{|l|c|c|c|c|c|c|c|c|}
\hline Installation & $\begin{array}{c}\text { Administrative } \\
\text { Buildings, General } \\
\text { Purpose }\end{array}$ & $\begin{array}{c}\text { General } \\
\text { Instruction } \\
\text { Building }\end{array}$ & $\begin{array}{c}\text { Enlisted } \\
\text { Unaccompanied } \\
\text { Personnel Housing }\end{array}$ & Museum & $\begin{array}{c}\text { Trainee } \\
\text { Bks }\end{array}$ & $\begin{array}{c}\text { Bn HQ* } \\
\text { Bldg }\end{array}$ & HDD & CDD \\
\hline Leavenworth & 32 & 4 & 0 & 1 & 0 & 0 & 5177 & 1590 \\
\hline Knox & 15 & 1 & 8 & 1 & 30 & 0 & 4602 & 1421 \\
\hline Sill & 10 & 4 & 19 & 7 & 5 & 8 & 3523 & 2831 \\
\hline Benning & 11 & 6 & 0 & 0 & 30 & 3 & 2643 & 2242 \\
\hline Riley & 21 & 1 & 16 & 8 & 0 & 1 & 5267 & 1843 \\
\hline Bragg & 14 & 0 & 12 & 2 & 0 & 11 & 2969 & 2127 \\
\hline Total & 103 & 16 & 55 & 19 & 65 & 23 & & \\
\hline *Battalion (Bn); Headquarters (HQ) & & & & & & & \\
\hline
\end{tabular}

One further criteria sought was the existence of a significant heating and cooling season. This is indicated from historical weather data that are summarized in terms of HDD and CDD. Fort Sill was found to have the highest combined heating and cooling needs, a fair number of historic buildings, and a good mix of historic building types.

The real property database (HQIIS) was studied to narrow down a specific list of buildings to be studied. Some key building characteristics contained in the database include Building Type, Design Use, and Current Use. Unfortunately nearly every item in every database listed the same code for both Design and Current use. It appears that when a building's Current Use is changed, the Design Use and Design Use changed to the same value. Six main building types were found (Table 5). Three building types were found to be most prevalent: Administrative General Purpose, Unaccompanied Enlisted Personnel Housing, and Trainee Barracks. Trainee Barracks were prevalent at two of the installations, but virtually non-existent at the others. As expected from the experiences of CERL's Cultural Resources Branch, the Administrative General Purpose were prevalent at all the listed installations. The Unaccompanied Enlisted Personnel Housing were fairly prevalent at most of the sites. The six building types were selected based on the available data and consultations with the sponsor. 


\section{Fort Sill and Buildings Modeled}

Fort Sill remains the only active Army installation of all the forts on the South Plains built during the Indian Wars. There were several major construction periods at Fort Sill Military Reservation during the $20^{\text {th }}$ century: the New Post construction period, ca. 1909-1911; the World War I mobilization construction period, ca.1917; the Academic area construction period, ca. 1933-1938; and the World War II mobilization construction period, 1939-1945. The last of these four construction phases, the World War II mobilization construction period, is addressed in this historic context. A vast amount of construction was carried out across the Nation from 1939 to 1945 , defined by John S. Garner as the years of World War II mobilization construction (Garner 1993. Smith 1970). War-related construction included the completion of both the Command Facilities, "designed for use in the actual maintenance and operation of the Army, rather than for purposes of procurement," and the Industrial Facilities, built for the production of war materiel.

\subsection{Building descriptions}

\subsubsection{Bldg. 441}

Figure 2. Bldg. 441.

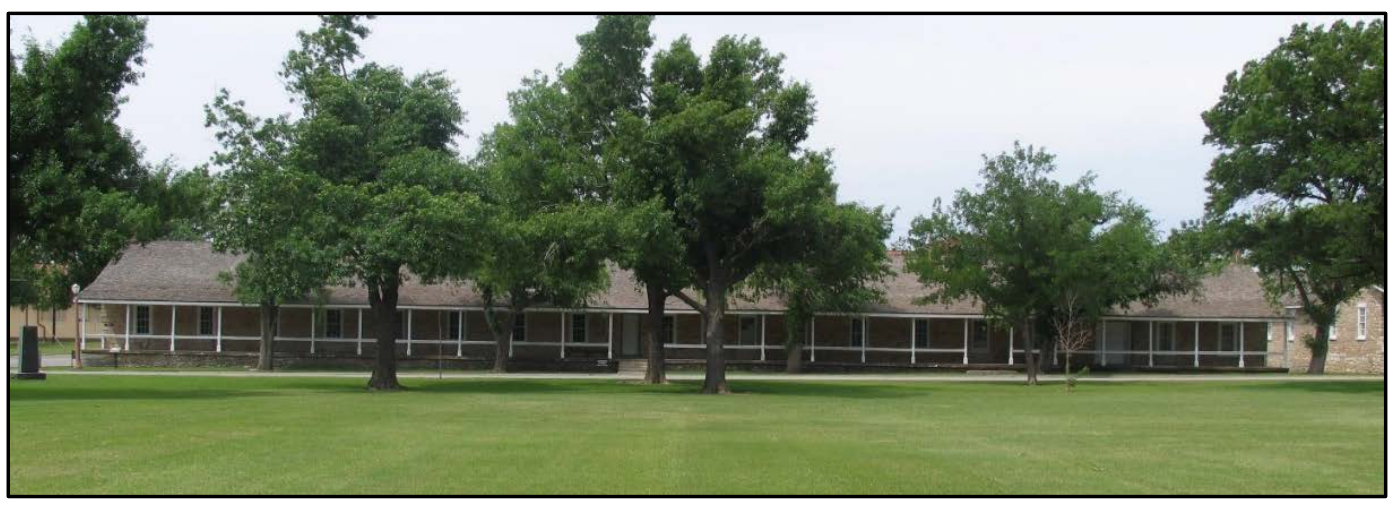

Table 6. Bldg. 441 details.

\begin{tabular}{|l|l|}
\hline Parameter & Measure \\
\hline Year Built & 1870 \\
\hline Square Footage $\left(\mathrm{ft}^{2}\right)$ & 10,614 \\
\hline \# of Stories & $1+1 / 2$ basement \\
\hline Use Type & Museum \\
\hline
\end{tabular}




\begin{tabular}{|c|c|}
\hline Parameter & Measure \\
\hline \multicolumn{2}{|l|}{ Envelope } \\
\hline \multicolumn{2}{|l|}{ Roof } \\
\hline Construction & Wood Frame (24 in o.c. est.), Shingles \\
\hline Insulation type and thickness & None (est.) \\
\hline \multicolumn{2}{|l|}{ Wall } \\
\hline Construction & Stone (10 in.) \\
\hline Insulation type/thickness/location & None \\
\hline \multicolumn{2}{|l|}{ Floor/Basement } \\
\hline Construction & Crawlspace/basement \\
\hline Insulation type/thickness/location & None \\
\hline \multicolumn{2}{|l|}{ Windows } \\
\hline Glazing/Frame/Features & Single Pane, Wood Frame, Tint \\
\hline Gross \% of wall area (Overall) & $10.2 \%$ \\
\hline \multicolumn{2}{|l|}{ Occupancy } \\
\hline Use type & Museum \\
\hline Hours & 0700-1700 M-F \\
\hline Average \# of Occupants (if available) & Not Applicable (N/A) \\
\hline \multicolumn{2}{|l|}{ HVAC } \\
\hline Heating System & Air Source Heat Pumps \\
\hline Cooling System & Air Source Heat Pumps \\
\hline Domestic Hot Water System & Natural Gas Fired, 30 Gallon Tank \\
\hline HVAC Controls & Thermostat \\
\hline \multicolumn{2}{|l|}{ Lighting and plug loads } \\
\hline Primary Lighting Type/Fixture & $\begin{array}{l}\text { T8 with some T12, Exhibits are light emitting diode (LED) } \\
\text { and incandescent }\end{array}$ \\
\hline Lighting Usage & On during occupied/off during unoccupied hours \\
\hline Lighting Controls & Switches \\
\hline
\end{tabular}

Bldg. 441 was originally built as a barracks for cavalry soldiers. At one time, the basement was used as a prison. Bldg. 441 is now a museum that has intermittent open hours, but is occupied regularly from 8 a.m. to 5 p.m. by staff who care for the contents, set up displays, and perform the other tasks necessary to keep the museum running. 


\subsubsection{Bldg. 462}

Figure 3. Bldg. 462.

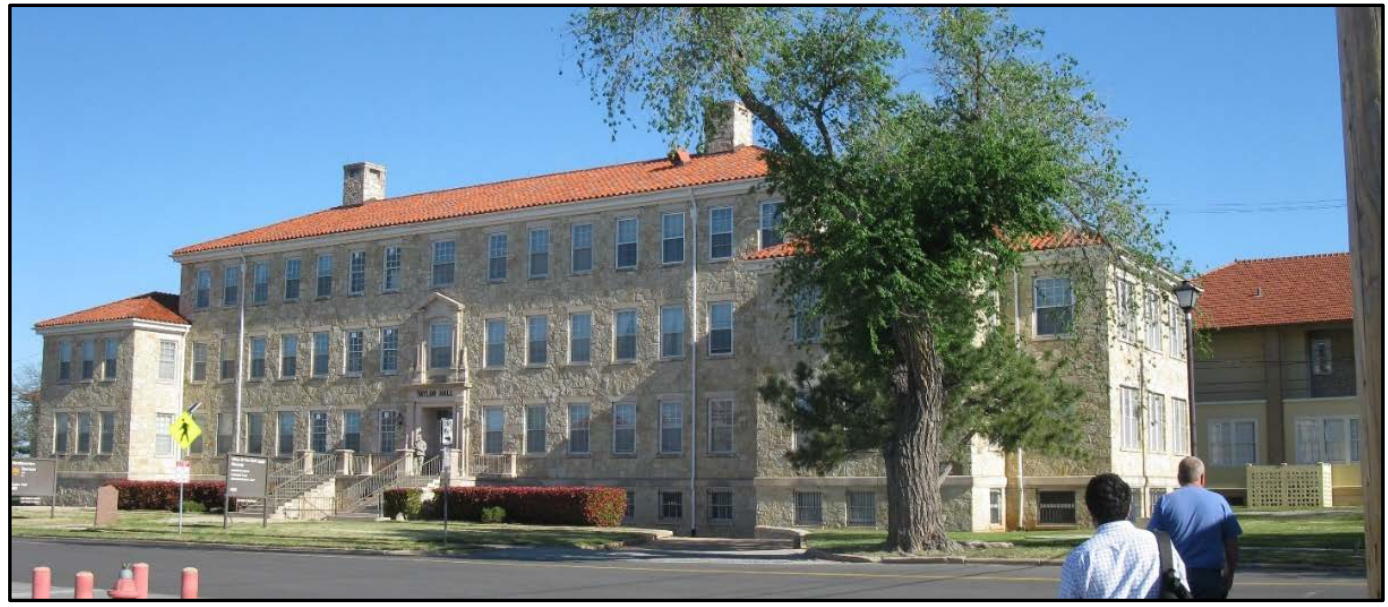

Table 7. Bldg. 462 details.

\begin{tabular}{|c|c|}
\hline Parameter & Measure \\
\hline Year Built & 1935 \\
\hline Square Footage $\mathrm{ft}^{2}$ & 33,425 \\
\hline \# of Stories & $3+$ basement \\
\hline Use Type & Administrative \\
\hline \multicolumn{2}{|l|}{ Envelope } \\
\hline \multicolumn{2}{|l|}{ Roof } \\
\hline Construction & Wood Frame (24 in o.c. est.), clay tiles \\
\hline Insulation type and thickness & R-13 batt, no rad barrier \\
\hline \multicolumn{2}{|l|}{ Wall } \\
\hline Construction & Concrete masonry unit (12 in.) \\
\hline Insulation type/thickness/location & None \\
\hline \multicolumn{2}{|l|}{ Floor/Basement } \\
\hline Construction & Basement \\
\hline Insulation type/thickness/location & None \\
\hline \multicolumn{2}{|l|}{ Windows } \\
\hline Glazing/Frame/Features & $\begin{array}{l}\text { Single Pane, Wood Frame, Clear } \\
\text { Double Pane, Aluminum Frame, Clear } \\
\text { Single Pane, Aluminum Frame, Clear }\end{array}$ \\
\hline Gross $\%$ of wall area (Overall) & $26.9 \%$ \\
\hline \multicolumn{2}{|l|}{ Occupancy } \\
\hline Use type & Administrative \\
\hline
\end{tabular}




\begin{tabular}{|l|l|}
\hline Parameter & Measure \\
\hline Hours & O700-1700 M-F \\
\hline Average \# of Occupants (if available) & N/A \\
\hline HVAC & Hot Water Coils \\
\hline Heating System & Chilled Water Coils \\
\hline Cooling System & Natural Gas Fired, 191 Gallon Tank \\
\hline Domestic Hot Water System & Thermostat \\
\hline HVAC Controls & \multicolumn{2}{|l|}{} \\
\hline Lighting and plug loads & Unknown \\
\hline Primary Lighting Type/Fixture & On during occupied/off during unoccupied hours \\
\hline Lighting Usage & Switches \\
\hline Lighting Controls? &
\end{tabular}

\subsubsection{Bldg. 463}

Figure 4. Bldg. 463.

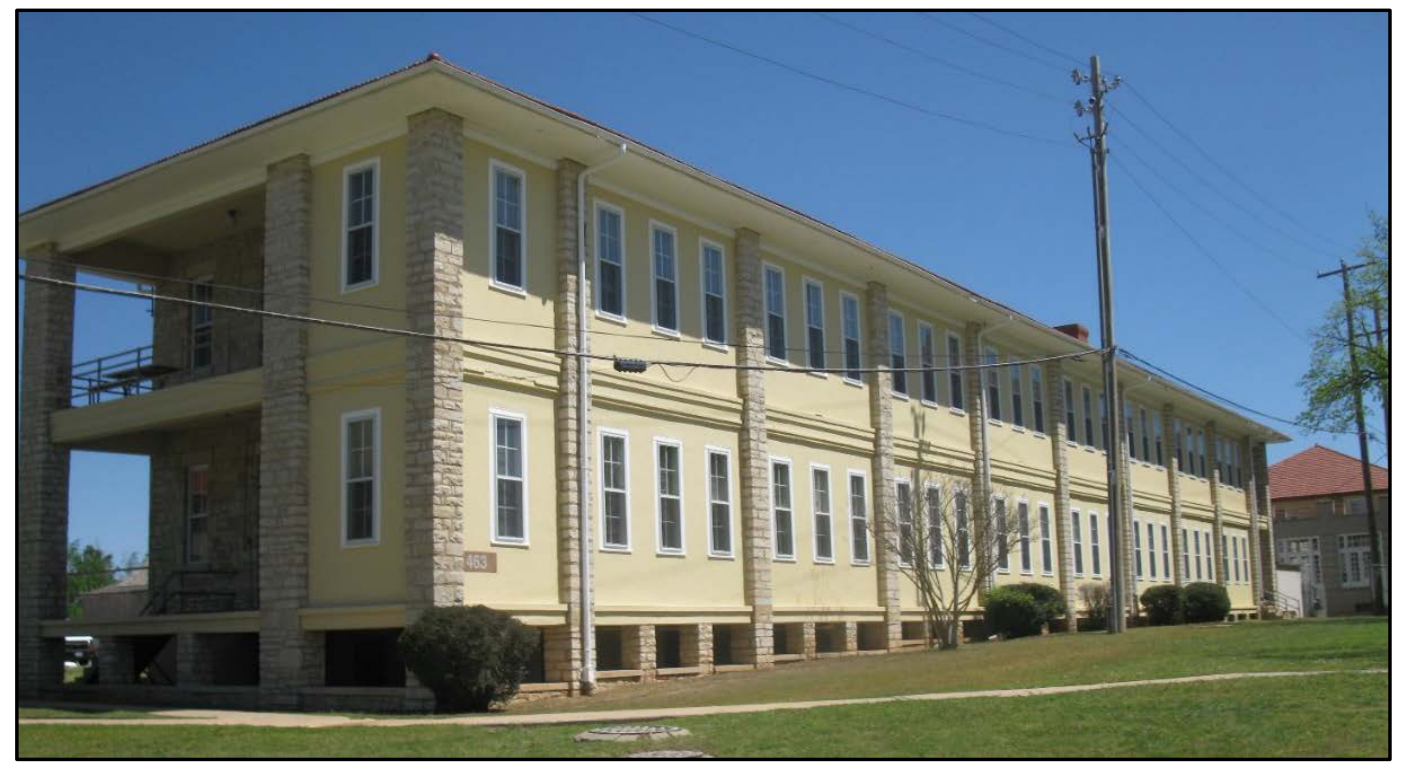

Table 8. Bldg. 463 details.

\begin{tabular}{|l|l|}
\hline Parameter & Measure \\
\hline Year Built & 1913 \\
\hline Square Footage $\mathrm{ft}^{2}$ & 18,170 \\
\hline \# of Stories & 2 + basement \\
\hline Use Type & Administrative \\
\hline Envelope & \\
\hline
\end{tabular}




\begin{tabular}{|c|c|}
\hline Parameter & Measure \\
\hline \multicolumn{2}{|l|}{ Roof } \\
\hline Construction & Wood Frame, Clay tiles \\
\hline Insulation type and thickness & None \\
\hline \multicolumn{2}{|l|}{ Wall } \\
\hline Construction & Concrete Masonry Unit (12 inches) \\
\hline Insulation type/thickness/location & Solid Grouted \\
\hline \multicolumn{2}{|l|}{ Floor/Basement } \\
\hline Construction & Crawlspace/basement \\
\hline Insulation type/thickness/location & None \\
\hline \multicolumn{2}{|l|}{ Windows } \\
\hline Glazing/Frame/Features & $\begin{array}{l}\text { Double Pane, Aluminum Frame, Clear } \\
\text { Double Pane, Aluminum Frame, Tint }\end{array}$ \\
\hline Gross $\%$ of wall area (Overall) & $47.3 \%$ \\
\hline \multicolumn{2}{|l|}{ Occupancy } \\
\hline Use type & Administrative \\
\hline Hours & 0800-1700 M-F \\
\hline Average \# of Occupants (if available) & N/A \\
\hline \multicolumn{2}{|l|}{ HVAC } \\
\hline Heating System & Hot Water Coils and Boiler \\
\hline Cooling System & Chilled Water Coils and Chiller \\
\hline Domestic Hot Water System & Natural Gas Fired, 28 Gallon Tank \\
\hline HVAC Controls & Thermostat \\
\hline \multicolumn{2}{|l|}{ Lighting and plug loads } \\
\hline Primary Lighting Type/Fixture & T8 with some T12, Exhibits are LED/INC* \\
\hline Lighting Usage & On during occupied/off during unoccupied hours \\
\hline Lighting Controls & Switches \\
\hline
\end{tabular}




\subsubsection{Bldg. 750}

Figure 5. Bldg. 750.

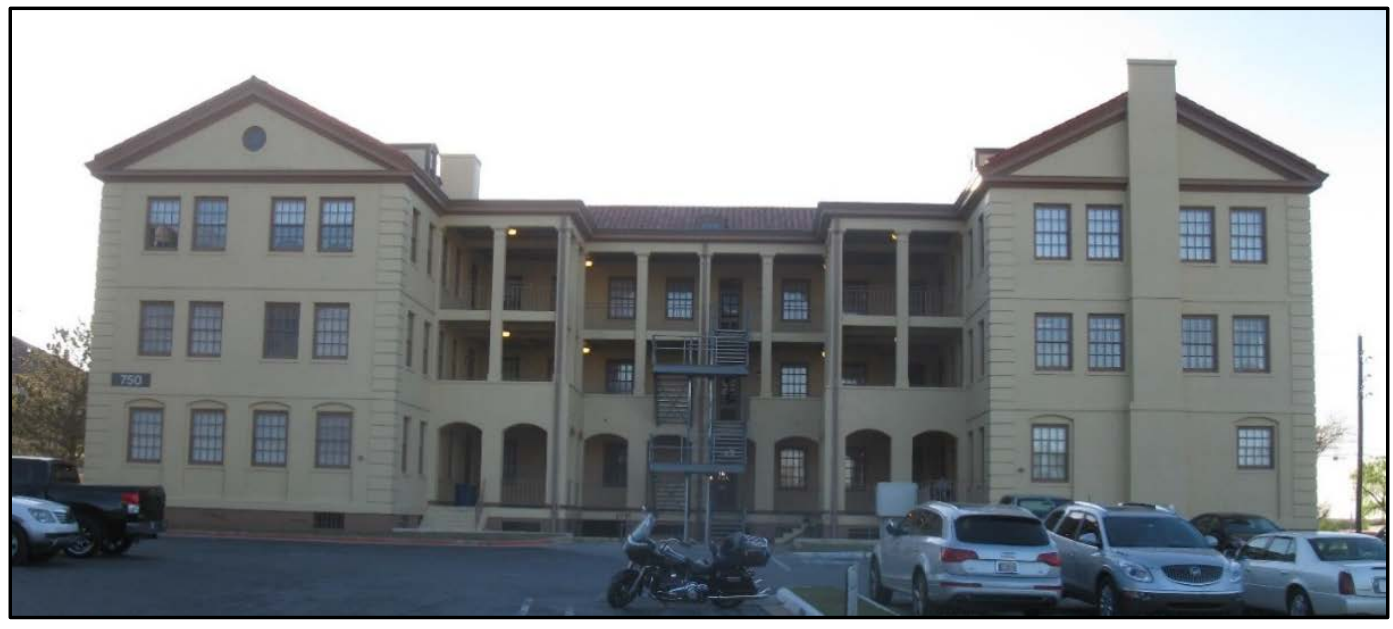

Table 9. Bldg. 750 details.

\begin{tabular}{|c|c|}
\hline Parameter & Measure \\
\hline Year Built & 1934 \\
\hline Square Footage $\mathrm{ft}^{2}$ & 38,480 \\
\hline \# of Stories & $3+$ basement \\
\hline Use Type & Administrative \\
\hline \multicolumn{2}{|l|}{ Envelope } \\
\hline \multicolumn{2}{|l|}{ Roof } \\
\hline Construction & Wood Frame, Clay tile \\
\hline Insulation type and thickness & None \\
\hline \multicolumn{2}{|l|}{ Wall } \\
\hline Construction & Concrete Masonry Unit (12 in. est.) \\
\hline Insulation type/thickness/location & Solid Grouted \\
\hline \multicolumn{2}{|l|}{ Floor/Basement } \\
\hline Construction & Basement \\
\hline Insulation type/thickness/location & None \\
\hline \multicolumn{2}{|l|}{ Windows } \\
\hline Glazing/Frame/Features & Single Pane, Wood Frame, Clear \\
\hline Gross \% of wall area (Overall) & $36.4 \%$ \\
\hline \multicolumn{2}{|l|}{ Occupancy } \\
\hline Use type & Administrative \\
\hline Hours & 0700-1700 M-F \\
\hline
\end{tabular}




\begin{tabular}{|l|l|}
\hline Parameter & Measure \\
\hline Average \# of Occupants (if available) & N/A \\
\hline HVAC & \multicolumn{2}{|l|}{ Hot Water Coils } \\
\hline Heating System & Chilled Water Coils \\
\hline Cooling System & Natural Gas Fired, 116 Gallon Tank \\
\hline Domestic Hot Water System & Thermostat \\
\hline HVAC Controls & \\
\hline Lighting and plug loads & T8 with some T12, Exhibits are LED/INC \\
\hline Primary Lighting Type/Fixture & On during occupied/off during unoccupied hours \\
\hline Lighting Usage & Switches \\
\hline Lighting Controls & \\
\hline
\end{tabular}

\subsubsection{Bldg. 1803}

Figure 6. Bldg. 1803.

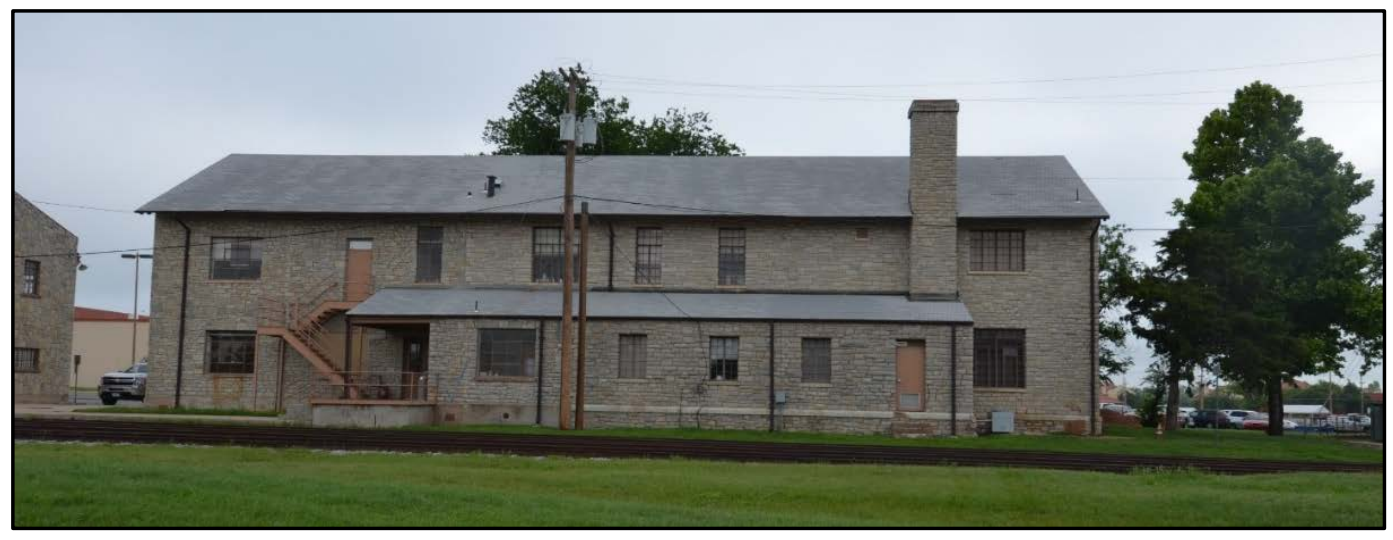

Table 10. Bldg. 1803 details.

\begin{tabular}{|l|l|}
\hline Parameter & Measure \\
\hline Year Built & 1939 \\
\hline Square Footage $\mathrm{ft}^{2}$ & 8,076 \\
\hline \# of Stories & $2+1 / 2$ basement \\
\hline Use Type & Administrative \\
\hline Envelope & \multicolumn{2}{|l|}{} \\
\hline Roof & Wood Frame, clay tiles \\
\hline Construction & None \\
\hline Insulation type and thickness & \multicolumn{2}{|l|}{} \\
\hline Wall & Stone \\
\hline Construction & \multicolumn{2}{|l|}{} \\
\hline
\end{tabular}




\begin{tabular}{|c|c|}
\hline Parameter & Measure \\
\hline Insulation type/thickness/location & None \\
\hline \multicolumn{2}{|l|}{ Floor/Basement } \\
\hline Construction & Crawlspace \\
\hline Insulation type/thickness/location & None (est.) \\
\hline \multicolumn{2}{|l|}{ Windows } \\
\hline Glazing/Frame/Features & Single Pane, Aluminum Frame \\
\hline Gross \% of wall area (Overall) & $20.1 \%$ \\
\hline \multicolumn{2}{|l|}{ Occupancy } \\
\hline Use type & Administrative \\
\hline Hours & 0800-1700 M-F \\
\hline Average \# of Occupants (if available) & N/A \\
\hline \multicolumn{2}{|l|}{ HVAC } \\
\hline Heating System & Ground Source Heat Pumps \\
\hline Cooling System & Ground Source Heat Pumps \\
\hline Domestic Hot Water System & Natural Gas Fired, 17 Gallon Tank \\
\hline HVAC Controls & Thermostat \\
\hline \multicolumn{2}{|l|}{ Lighting and plug loads } \\
\hline Primary Lighting Type/Fixture & T8 with some T12, Exhibits are LED/INC \\
\hline Lighting Usage & On during occupied/off during unoccupied hours \\
\hline Lighting Controls? & Switches \\
\hline
\end{tabular}

\subsubsection{Bldg. 3419}

Table 11. Bldg. 3419 details.

\begin{tabular}{|l|l|}
\hline Parameter & Measure \\
\hline Year Built & 1954 \\
\hline Square Footage $\mathrm{ft}^{2}$ & 37,735 \\
\hline \# of Stories & $3+$ basement \\
\hline Use Type & Administrative \\
\hline Envelope & \multicolumn{2}{|l|}{} \\
\hline Roof & Concrete (4 in.) \\
\hline Construction & None \\
\hline Insulation type and thickness & \multicolumn{2}{|l|}{} \\
\hline Wall & Concrete Masonry Unit (12 in. est.) \\
\hline Construction & None \\
\hline Insulation type/thickness/location &
\end{tabular}




\begin{tabular}{|c|c|}
\hline Parameter & Measure \\
\hline \multicolumn{2}{|l|}{ Floor/Basement } \\
\hline Construction & Basement \\
\hline Insulation type/thickness/location & None \\
\hline \multicolumn{2}{|l|}{ Windows } \\
\hline Glazing/Frame/Features & Double Pane, Aluminum Frame, Clear \\
\hline Gross \% of wall area (Overall) & $12.0 \%$ \\
\hline \multicolumn{2}{|l|}{ Occupancy } \\
\hline Use type & Administrative \\
\hline Hours & 0700-1800 M-F \\
\hline Average \# of Occupants (if available) & $\mathrm{N} / \mathrm{A}$ \\
\hline \multicolumn{2}{|l|}{ HVAC } \\
\hline Heating System & Hot Water Coils \\
\hline Cooling System & Chilled Water Coils \\
\hline Domestic Hot Water System & Natural Gas Fired, 149 Gallon Tank \\
\hline HVAC Controls & Thermostat \\
\hline \multicolumn{2}{|l|}{ Lighting and plug loads } \\
\hline Primary Lighting Type/Fixture & T8 with some T12, Exhibits are LED/INC \\
\hline Lighting Usage & On during occupied/off during unoccupied hours \\
\hline Lighting Controls & Switches \\
\hline
\end{tabular}

\subsection{Approach to finding and evaluating ECMs}

The first step of the analysis was to model the buildings as they exist, to review the modeled energy use, and to compare expected use to metered data in the cases in which reliable metered data were available. Where metered data were available, data from Fiscal Year 2015 (FY15) were used. The energy modeling software used here (eQUEST) uses a 30-year average climate data. The 30-year weather data were compared to FY15 weather data and it was found that there were $16 \%$ more Cooling Degree Days (a measure of required cooling) and 4\% fewer HDD (a measure of required heating) in FY15. Unfortunately many of the buildings that were modeled either had no metered data or had data that were unreliable. When that was the case a typical Energy Use Index (EUI) was used to evaluate the reasonableness of the results. EUI is a measure of a building's annual energy use per area of building envelope. This of course varied with a number of factors, some of the major ones being the type of building use and climate zone. A database of EUIs, created from data contained in the 2003 
Commercial Buildings Energy Consumption Survey (CBECS) was used to get an average EUI for buildings as close as possible to the buildings modeled (Column "EUI Typical" in Table 12). Parameters used to get a typical EUI for a particular building type include age, use type, HDD, and CDD. Table 12 summarizes the modeling results.

Second, the building models were evaluated to identify retrofits that had already been done that affect energy use and that were likely not to have been done to similar buildings. The retrofits that were thought may not have been done to similar buildings were removed from the models. This was done so that the potential measure to save energy would not be lost on other potential buildings solely because it had already been done on the particular building that was modeled. Retrofits that likely have been done to most buildings were kept in the "Original State" model. Many historic buildings for instance were not originally air-conditioned, but if they are currently used as an administrative building they most likely have been retrofitted with air-conditioning.

Third, ECMs were put in the models and evaluated for energy and cost savings to determine those that are most economically viable. Only measures that could be feasibly done on a historic structure were evaluated. Insulation on the exterior, for example, was not evaluated.

The fourth and final step in modeling was to evaluate the models for other climate zones.

Utility rates reflecting the average DoD cost (according to DoD Energy Management Report 2015) of $\$ 0.0939 / \mathrm{kWh}$ and $\$ 0.7780 /$ therm natural gas were used for all sites.

\subsubsection{Bldg. 441 energy use - "as is"}

An eQUEST model was created for the building in its current state and the building energy use was simulated. Figure 7 shows the results. 


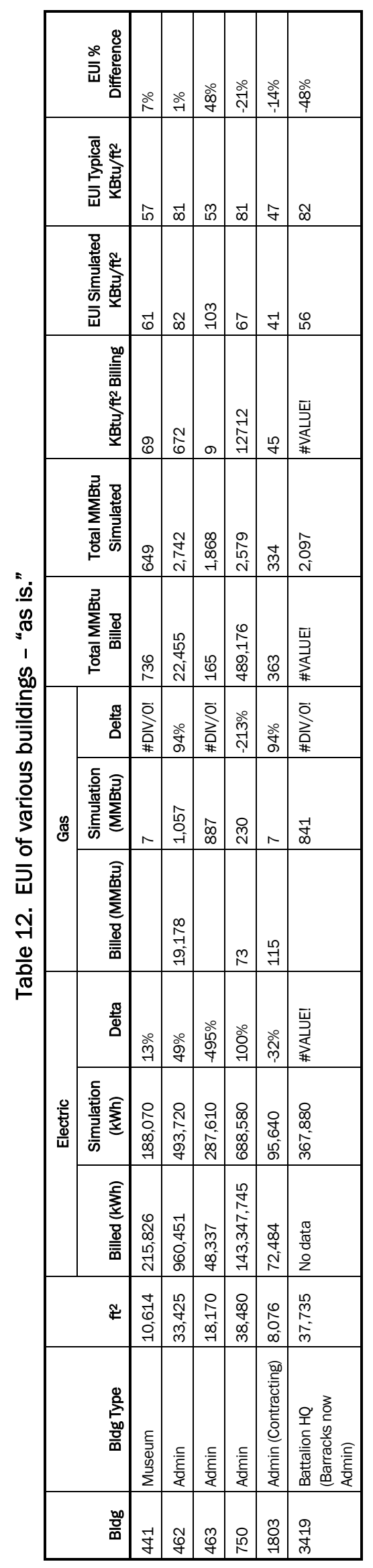


Figure 7. Bldg 441 “as is" annual energy use.

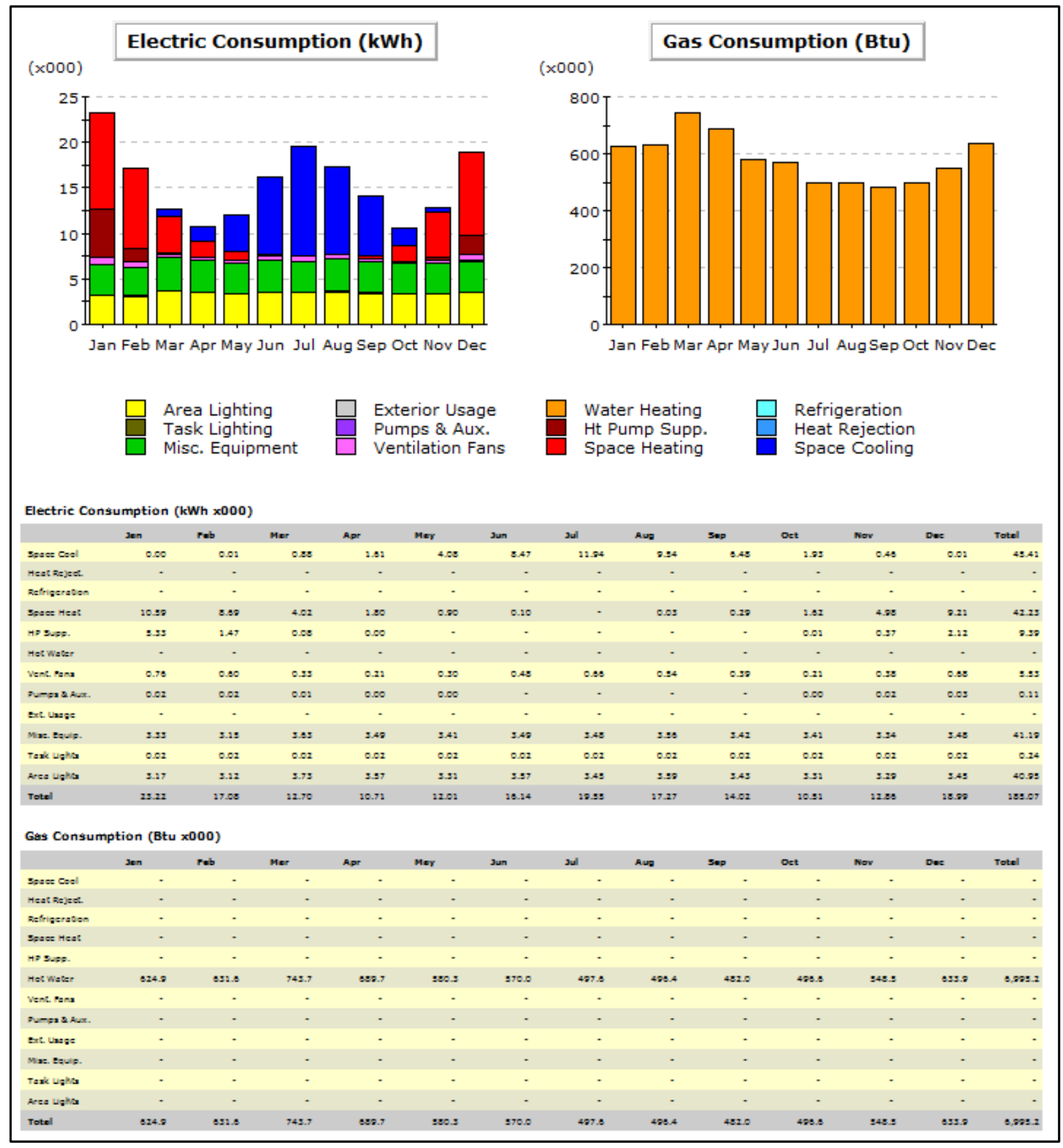

The simulated annual energy use for Bldg 441 is $188,070 \mathrm{kWh} /$ year of electricity and $7 \mathrm{MMBtu} /$ year of gas. With $10,614 \mathrm{ft}^{2}$ of envelope area, this equates to an EUI of $60 \mathrm{kBtu} / \mathrm{ft}^{2} / \mathrm{yr}$. According to the CBECS survey, the typical EUI for this building type in this climate is $57 \mathrm{kBtu} / \mathrm{ft}^{2} / \mathrm{yr}$. This is a good correlation. 


\subsubsection{Bldg. 462 energy use - "as is"}

The simulated annual energy use for Bldg. 462 is $493,720 \mathrm{kWh} /$ year of electricity and 1,057.3 MMBtu/year of gas. With 33,425 $\mathrm{ft}^{2}$ of envelope area, this equates to an EUI of $82 \mathrm{kBtu} / \mathrm{ft}^{2} / \mathrm{yr}$. According to the CBECS survey, the typical EUI for this building type in this climate is 81 $\mathrm{kBtu} / \mathrm{ft}^{2} / \mathrm{yr}$. This is a good correlation.

\subsubsection{Bldg. 463 energy use - "as is"}

The simulated annual energy use for Bldg. 463 is $287,610 \mathrm{kWh} /$ year of electricity and $887 \mathrm{MMBtu} /$ year of gas. With $18,170 \mathrm{ft}^{2}$ of envelope area, this equates to an EUI of $103 \mathrm{kBtu} / \mathrm{ft}^{2} / \mathrm{yr}$. According to the CBECS survey, the typical EUI for this building type in this climate is $53 \mathrm{kBtu} / \mathrm{ft}^{2} / \mathrm{yr}$, a significant difference. There are many reasons for this large difference. The building currently has virtually no insulation, a clay roof, and masonry walls. The cooling system energy usage is also relatively high at 1.3 $\mathrm{kW} /$ ton. So while the modeled energy use was different than initially expected, it is believed to be an accurate model.

\subsubsection{Bldg. 750 energy use - "as is"}

The simulated annual energy use for Bldg. 750 is $688,580 \mathrm{kWh} /$ year of electricity and 229.9 MMBtu/year of gas. With $38,480 \mathrm{ft}^{2}$ of envelope area, this equates to an EUI of $67 \mathrm{kBtu} / \mathrm{ft}^{2} / \mathrm{yr}$. According to the CBECS survey, the typical EUI for this building type in this climate is $81 \mathrm{kBtu} / \mathrm{ft}^{2} / \mathrm{yr}$. This can be partially explained by the upgraded HVAC system that is likely more efficient than the typical system in this building type. This is considered close enough to make the model feasible.

\subsubsection{Bldg. 1803 energy use - "as is"}

The simulated annual energy use for Bldg. 1803 is $95,640 \mathrm{kWh} /$ year of electricity and 7.17 MMBtu/year of gas. With $8,076 \mathrm{ft}^{2}$ of envelope area, this equates to an EUI of $41 \mathrm{kBtu} / \mathrm{ft}^{2} / \mathrm{yr}$. According to the CBECS survey, the typical EUI for this building type in this climate is $47 \mathrm{kBtu} / \mathrm{ft}^{2} / \mathrm{yr}$. This is considered close enough to make the model feasible. 


\subsubsection{Bldg. 3419 energy use - "as is"}

The simulated annual energy use for Bldg. 3419 is $367,880 \mathrm{kWh} /$ year of electricity and 841.31 MMBtu/year of gas. With $37,735 \mathrm{ft}^{2}$ of envelope area, this equates to an EUI of $56 \mathrm{kBtu} / \mathrm{ft}^{2} / \mathrm{yr}$. According to the CBECS survey, the typical EUI for this building type in this climate is $82 \mathrm{kBtu} / \mathrm{ft}^{2} / \mathrm{yr}$. This is a $48 \%$ difference. The reason for this is that Bldg. 3419 has been recently renovated with many energy savings features. So while the modeled energy use was different than initially expected, it is believed to be an accurate model.

\subsection{The building model results - "Original State"}

The buildings were next modeled to reflect the state that they would have been expected to be in from the original construction. Retrofits that would have had to have been done to maintain the building in a useful state were left in the model. Retrofits that were done to save energy were removed from the model so that the effect could be evaluated for other buildings of the same type. The most significant changes made to return the buildings to their "original state" were:

- no scheduling of mechanical equipment

- no unoccupied setback of temperatures

- less efficient heating and cooling equipment.

\subsubsection{Bldg. 441 energy use - "Original State"}

The simulated annual energy use for Bldg. 441 is $621,745 \mathrm{kWh} /$ year of electricity and 42.4 MMBtu/year of gas. With 10,614 $\mathrm{ft}^{2}$ of envelope area, this equates to an EUI of $204 \mathrm{kBtu} / \mathrm{ft}^{2} / \mathrm{yr}$.

\subsubsection{Bldg. 462 energy use - "Original State"}

The simulated annual energy use for Bldg. 462 is 959,081 kWh/year of electricity and 3,298.4 MMBtu/year of gas. With 33,425 $\mathrm{ft}^{2}$ of envelope area, this equates to an EUI of $197 \mathrm{kBtu} / \mathrm{ft}^{2} / \mathrm{yr}$.

\subsubsection{Bldg. 463 energy use - "Original State"}

The simulated annual energy use for Bldg. 463 is 1,960,400 kWh/year of electricity and 4,937.3 MMBtu/year of gas. With $18,170 \mathrm{ft}^{2}$ of envelope area, this equates to an EUI of $640 \mathrm{kBtu} / \mathrm{ft}^{2} / \mathrm{yr}$. 


\subsubsection{Bldg. 750 energy use - "Original State"}

The simulated annual energy use for Bldg. 750 is $1,442,616 \mathrm{kWh} /$ year of electricity and 1,171 MMBtu/year of gas. With 38,480 ft² of envelope area, this equates to an EUI of $158 \mathrm{kBtu} / \mathrm{ft}^{2} / \mathrm{yr}$.

\subsubsection{Bldg. 1803 energy use - "Original State"}

The simulated annual energy use for Bldg. 1803 is $450,660 \mathrm{kWh} /$ year of electricity and 2,765 MMBtu/year of gas. With 8,076 $\mathrm{ft}^{2}$ of envelope area, this equates to an EUI of $533 \mathrm{kBtu} / \mathrm{ft}^{2} / \mathrm{yr}$.

\subsubsection{Bldg. 3419 energy use - "Original State"}

The simulated annual energy use for Bldg. 3419 is $1,127,300 \mathrm{kWh} /$ year of electricity and 4,857.4 MMBtu/year of gas (Table 13). With 37,735 $\mathrm{ft}^{2}$ of envelope area, this equates to an EUI of $231 \mathrm{kBtu} / \mathrm{ft}^{2} / \mathrm{yr}$.

Table 13. Summary of "as is" and original energy use.

\begin{tabular}{|c|c|c|c|c|c|c|}
\hline & \multicolumn{3}{|c|}{ As Is } & \multicolumn{3}{c|}{ Original State } \\
\hline Building & $\begin{array}{c}\text { Electric Use } \\
(\mathrm{kWh})\end{array}$ & $\begin{array}{c}\text { Gas Use } \\
(\mathrm{MMBtu})\end{array}$ & $\begin{array}{c}\text { EUI } \\
\left(\mathrm{kBtu} / \mathrm{ft}^{2} / \mathrm{yr}\right)\end{array}$ & $\begin{array}{c}\text { Electric Use } \\
(\mathrm{kWh})\end{array}$ & $\begin{array}{c}\text { Gas Use } \\
(\mathrm{MMBtu})\end{array}$ & $\begin{array}{c}\text { EUI } \\
\left(\mathrm{kBtu} / \mathrm{ft}^{2} / \mathrm{yr}\right)\end{array}$ \\
\hline 441 & 188,070 & 7 & 61 & 621,745 & 42 & 204 \\
\hline 462 & 493,720 & 1,057 & 82 & 959,081 & 3,298 & 197 \\
\hline 463 & 287,610 & 887 & 103 & $1,960,400$ & 4,937 & 640 \\
\hline 750 & 688,580 & 230 & 67 & $1,442,616$ & 1,171 & 158 \\
\hline 1803 & 95,640 & 7 & 41 & 450,660 & 2,765 & 533 \\
\hline 3419 & 367,880 & 841 & 56 & $1,127,300$ & 4,857 & 231 \\
\hline
\end{tabular}

\subsection{Energy efficiency measures}

When considering an energy conservation retrofit on a historic building, the report from past Legacy Project 11-382 "Design Guidelines for Implementing Energy Efficiency Strategies in Historic Properties" is a good reference for determining when a potential retrofit is appropriate. The following measures were considered for all buildings. Those that seemed practical for a particular building were then simulated using the "Original" building model modified to include the EEM, for which the savings were calculated. The EEMs for the Fort Sill buildings were run independently of each other. This means that interactions between measures were not taken into account. If multiple measures are performed, the total actual savings would likely be less than predicted. Costs were estimated using RS Means 
data. Most costs were taken from Commercial Renovation Cost Data 2014 and increased at a rate of $3 \%$ per year:

- infiltration reduction

o windows

○ doors

$\circ$ penetrations

- lighting fixture/lamp improvements

- lighting controls

- wall insulation

- roof/attic insulation

- replacement of mechanical equipment

- add storm windows

- add roof/ceiling insulation

- programmable thermostat

- duct and pipe insulation

- awning/shading

- PV cells

- solar hot water

- replace mechanical equipment controls

- PV panels.

\subsubsection{Bldg. 441 EEM Descriptions, implementation costs and savings by climate zone}

The EEMs chosen for Bldg. 441 were:

- Reduce Infiltration by weatherstripping windows and doors. Changed from 2.00 air changes per hour $(\mathrm{ACH})$ to $1.00 \mathrm{ACH}$. The implementation cost was calculated from 66 windows that are $3.16 \times 5.33$ $\mathrm{ft}$, two doors that are $6.5 \times 7.1 \mathrm{ft}$, and six doors that are $6 \times 3 \mathrm{ft}$ for a total of $1,251 \mathrm{ft}$ of weatherstripping, at a cost of $\$ 4.41 / \mathrm{ft}$ for a total of $\$ 5,517$.

- Wall Insulation. Add 2 in. polystyrene (R-8) exterior board insulation to the exterior building walls, where previously there was no insulation. The cost of installing the insulation was estimated using RSMeans. At $\$ 1.62 / \mathrm{ft}^{2}$ and a wall area of approximately $10,614 \mathrm{ft}^{2}$, the total estimated cost is $\$ 17,232$.

- Roof/Attic Insulation. Add R-38 batt insulation plus radiant barrier to the roof, where previously there was no insulation. The implementation cost was calculated from 10,614 sq. $\mathrm{ft}$. of the building. The cost of 
the insulation was found to be $\$ 1.93 / \mathrm{ft}^{2}$ in 2014 , to which an escalation of $3 \%$ per year was added.

- Replace Mechanical Equipment Controls. Change the building from an occupancy of 24 hours per day every day of the week to an occupancy of 0700-1700 M-F, and unoccupied Sa-Su and on Holidays. Also change the temperature setpoints from occupied and unoccupied cooling and heating of 76 and $74^{\circ} \mathrm{F}$, to occupied cooling and heating of 78 and $68{ }^{\circ} \mathrm{F}$ and unoccupied cooling and heating of 85 and $55^{\circ} \mathrm{F}$, respectively. The HVAC system fans were set to operate 2 hours before open and 2 hours after close of the building. The fans were set to cycle at night with no Outside Air, to cycle on via Control Zones only, and to have the capability to operate in a continuous ON mode. When the fan's ON mode is set to continuous, the fan is run continuously during on periods, as opposed to only when heating or cooling is needed. Six thermostats (one for each heat unit) can be used to achieve the above recommendations. A cost of $\$ 300$ for the thermostat and 2 hours $(\$ 80 / \mathrm{hr})$ of fixed labor is assumed for a total cost of $\$ 2760$.

The model was then run for each EEM in each of the different climate zones using eQUEST. The results are listed in Tables 14-28 and shown in Figures 8-15.

Table 14. Bldg. 441, savings and payback summary, Climate Zone 1A (Miami, FL).

\begin{tabular}{|c|c|c|c|c|c|}
\hline EEM & $\begin{array}{c}\text { Electrical } \\
\text { Savings } \\
\text { (kWh/yr) }\end{array}$ & $\begin{array}{c}\text { Thermal } \\
\text { Savings } \\
\text { (Mil. Btu/yr) }\end{array}$ & $\begin{array}{c}\text { Annual Cost } \\
\text { Savings }\end{array}$ & $\begin{array}{l}\text { Implementation } \\
\text { Costs }\end{array}$ & $\begin{array}{l}\text { Payback } \\
\text { Period (yrs) }\end{array}$ \\
\hline Reduce Infiltration & 9,565 & 0 & $\$ 898$ & $\$ 5,516.38$ & 6.1 \\
\hline Wall Insulation & -914 & 0 & $-\$ 86$ & $\$ 17,232$ & -200.8 \\
\hline Roof/Attic Insulation & 10,234 & 0 & $\$ 961$ & $\$ 27,429.44$ & 28.5 \\
\hline Replace Mechanical Equipment Controls & 319,071 & -1 & $\$ 29,953$ & $\$ 2,760$ & 0.2 \\
\hline Total & 337,956 & -1 & $\$ 31,726$ & $\$ 55,469.82$ & 1.7 \\
\hline
\end{tabular}


Table 15. Bldg. 441, savings and payback summary, Climate Zone 2A (Houston, TX).

\begin{tabular}{|c|c|c|c|c|c|}
\hline EEM & $\begin{array}{c}\text { Electrical } \\
\text { Savings } \\
\text { (kWh/yr) }\end{array}$ & $\begin{array}{c}\text { Thermal } \\
\text { Savings } \\
\text { (Mil. Btu/yr) }\end{array}$ & $\begin{array}{c}\text { Annual Cost } \\
\text { Savings }\end{array}$ & $\begin{array}{l}\text { Implementation } \\
\text { Costs }\end{array}$ & $\begin{array}{c}\text { Payback } \\
\text { Period (yrs) }\end{array}$ \\
\hline Reduce Infiltration & 28,936 & 0 & $\$ 2,717$ & $\$ 5,516$ & 2.0 \\
\hline Wall Insulation & 30,304 & 0 & $\$ 2,846$ & $\$ 17,232$ & 6.1 \\
\hline Roof/Attic Insulation & 13,127 & 0 & $\$ 1,233$ & $\$ 27,429$ & 22.3 \\
\hline $\begin{array}{l}\text { Replace Mechanical Equipment } \\
\text { Controls }\end{array}$ & 304,643 & -1 & $\$ 28,598$ & $\$ 2,760$ & 0.1 \\
\hline Total & 377,010 & -1 & $\$ 35,393$ & 52,938 & 1.5 \\
\hline
\end{tabular}

Table 16. Bldg. 441, savings and payback summary, Climate Zone 2B (Phoenix, AZ).

\begin{tabular}{|l|c|c|c|c|c|}
\hline EEM & $\begin{array}{c}\text { Electrical } \\
\text { Savings } \\
(\mathbf{k W h} / \mathbf{y r})\end{array}$ & $\begin{array}{c}\text { Thermal } \\
\text { Savings } \\
(\text { Mil. Btu/yr) }\end{array}$ & $\begin{array}{c}\text { Annual Cost } \\
\text { Savings }\end{array}$ & $\begin{array}{c}\text { Implementation } \\
\text { Costs }\end{array}$ & $\begin{array}{c}\text { Payback } \\
\text { Period (yrs) }\end{array}$ \\
\hline Reduce Infiltration & 19,407 & 0 & $\$ 1,822$ & $\$ 5,516$ & 3.0 \\
\hline Wall Insulation & 18,799 & 0 & $\$ 1,765$ & $\$ 17,232$ & 9.8 \\
\hline Roof/Attic Insulation & 15,076 & 0 & $\$ 1,416$ & $\$ 27,429$ & 19.4 \\
\hline Replace Mechanical Equipment Controls & 276,966 & -1 & $\$ 25,999$ & $\$ 2,760$ & 0.1 \\
\hline Total & $\mathbf{3 3 0 , 2 4 8}$ & $-\mathbf{1}$ & $\mathbf{\$ 3 1 , 0 0 3}$ & $\mathbf{5 2 , 9 3 8}$ & $\mathbf{1 . 7}$ \\
\hline
\end{tabular}

Table 17. Bldg. 441, savings and payback summary, Climate Zone 3A (Memphis, TN).

\begin{tabular}{|l|c|c|c|c|c|}
\hline EEM & $\begin{array}{c}\text { Electrical } \\
\text { Savings } \\
(\mathbf{k W h} / \mathbf{y r})\end{array}$ & $\begin{array}{c}\text { Thermal } \\
\text { Savings } \\
\text { (Mil. Btu/yr) }\end{array}$ & $\begin{array}{c}\text { Annual Cost } \\
\text { Savings }\end{array}$ & $\begin{array}{c}\text { Implementation } \\
\text { Costs }\end{array}$ & $\begin{array}{c}\text { Payback } \\
\text { Period (yrs) }\end{array}$ \\
\hline Reduce Infiltration & 33,763 & 0 & $\$ 3,170$ & $\$ 5,516$ & 1.7 \\
\hline Wall Insulation & 39,153 & 0 & $\$ 3,676$ & $\$ 17,232$ & 4.7 \\
\hline Roof/Attic Insulation & 14,391 & 0 & $\$ 1,351$ & $\$ 27,429$ & 20.3 \\
\hline Replace Mechanical Equipment Controls & 308,351 & -1 & $\$ 28,946$ & $\$ 2,760$ & 0.1 \\
\hline Total & 395,658 & -1 & $\$ 37,145$ & 52,938 & 1.4 \\
\hline
\end{tabular}

Table 18. Bldg. 441, savings and payback summary, Climate Zone 3B (EI Paso, TX).

\begin{tabular}{|l|c|c|c|c|c|}
\hline EEM & $\begin{array}{c}\text { Electrical } \\
\text { Savings } \\
(\mathrm{kWh} / \mathrm{yr})\end{array}$ & $\begin{array}{c}\text { Thermal } \\
\text { Savings } \\
(\text { Mil. Btu/yr) }\end{array}$ & $\begin{array}{c}\text { Annual Cost } \\
\text { Savings }\end{array}$ & $\begin{array}{c}\text { Implementation } \\
\text { Costs }\end{array}$ & $\begin{array}{c}\text { Payback } \\
\text { Period (yrs) }\end{array}$ \\
\hline Reduce Infiltration & 20,356 & 0 & $\$ 1,911$ & $\$ 5,516$ & 2.9 \\
\hline Wall Insulation & 22,540 & 0 & $\$ 2,117$ & $\$ 17,232$ & 8.1 \\
\hline Roof/Attic Insulation & 15,246 & 0 & $\$ 1,432$ & $\$ 27,429$ & 19.2 \\
\hline Replace Mechanical Equipment Controls & 271,602 & -1 & $\$ 25,496$ & $\$ 2,760$ & 0.1 \\
\hline Total & $\mathbf{3 2 9 , 7 4 4}$ & -1 & $\$ 30,955$ & 52,938 & 1.7 \\
\hline
\end{tabular}


Table 19. Bldg. 441, savings and payback summary, Climate Zone 3C (San Francisco, CA).

\begin{tabular}{|l|c|c|c|c|c|}
\hline EEM & $\begin{array}{c}\text { Electrical } \\
\text { Savings } \\
(\mathbf{k W h} / \mathbf{y r})\end{array}$ & $\begin{array}{c}\text { Thermal } \\
\text { Savings } \\
(\text { Mil. Btu/yr) }\end{array}$ & $\begin{array}{c}\text { Annual Cost } \\
\text { Savings }\end{array}$ & $\begin{array}{c}\text { Implementation } \\
\text { Costs }\end{array}$ & $\begin{array}{c}\text { Payback } \\
\text { Period (yrs) }\end{array}$ \\
\hline Reduce Infiltration & 17,387 & 0 & $\$ 1,633$ & $\$ 5,516$ & 3.4 \\
\hline Wall Insulation & 18,674 & 0 & $\$ 1,753$ & $\$ 17,232$ & 9.8 \\
\hline Roof/Attic Insulation & 4,644 & 0 & $\$ 436$ & $\$ 27,429$ & 62.9 \\
\hline Replace Mechanical Equipment Controls & 230,372 & -1 & $\$ 21,624$ & $\$ 2,760$ & 0.1 \\
\hline Total & $\mathbf{2 7 1 , 0 7 7}$ & -1 & $\mathbf{\$ 2 5 , 4 4 6}$ & $\mathbf{5 2 , 9 3 8}$ & $\mathbf{2 . 1}$ \\
\hline
\end{tabular}

Table 20. Bldg. 441, savings and payback summary, Climate Zone 4A (Baltimore, MD).

\begin{tabular}{|l|c|c|c|c|c|}
\hline EEM & $\begin{array}{c}\text { Electrical } \\
\text { Savings } \\
(\mathbf{k W h} / \mathbf{y r})\end{array}$ & $\begin{array}{c}\text { Thermal } \\
\text { Savings } \\
(\text { Mil. Btu/yr) }\end{array}$ & $\begin{array}{c}\text { Annual Cost } \\
\text { Savings }\end{array}$ & $\begin{array}{c}\text { Implementation } \\
\text { Costs }\end{array}$ & $\begin{array}{c}\text { Payback } \\
\text { Period (yrs) }\end{array}$ \\
\hline Reduce Infiltration & 38,851 & 0 & $\$ 3,648$ & $\$ 5,516$ & 1.5 \\
\hline Wall Insulation & 46,040 & 0 & $\$ 4,323$ & $\$ 17,232$ & 4.0 \\
\hline Roof/Attic Insulation & 18,075 & 0 & $\$ 1,697$ & $\$ 27,429$ & 16.2 \\
\hline Replace Mechanical Equipment Controls & 319,336 & -1 & $\$ 29,978$ & $\$ 2,760$ & 0.1 \\
\hline Total & $\mathbf{4 2 2 , 3 0 2}$ & -1 & $\$ 39,646$ & $\mathbf{5 2 , 9 3 8}$ & 1.3 \\
\hline
\end{tabular}

Table 21. Bldg. 441, savings and payback summary, Climate Zone 4B (Albuquerque, NM).

\begin{tabular}{|l|c|c|c|c|c|}
\hline EEM & $\begin{array}{c}\text { Electrical } \\
\text { Savings } \\
(\mathbf{k W h} / \mathbf{y r})\end{array}$ & $\begin{array}{c}\text { Thermal } \\
\text { Savings } \\
\text { (Mil. Btu/yr) }\end{array}$ & $\begin{array}{c}\text { Annual Cost } \\
\text { Savings }\end{array}$ & $\begin{array}{c}\text { Implementation } \\
\text { Costs }\end{array}$ & $\begin{array}{c}\text { Payback } \\
\text { Period (yrs) }\end{array}$ \\
\hline Reduce Infiltration & 25,903 & 0 & $\$ 2,432$ & $\$ 5,516$ & 2.3 \\
\hline Wall Insulation & 34,426 & 0 & $\$ 3,233$ & $\$ 17,232$ & 5.3 \\
\hline Roof/Attic Insulation & 21,181 & 0 & $\$ 1,989$ & $\$ 27,429$ & 13.8 \\
\hline Replace Mechanical Equipment Controls & 312,257 & -1 & $\$ 29,313$ & $\$ 2,760$ & 0.1 \\
\hline Total & 393,767 & -1 & $\$ 36,967$ & 52,938 & 1.4 \\
\hline
\end{tabular}

Table 22. Bldg. 441, savings and payback summary, Climate Zone 4C (Seattle, WA).

\begin{tabular}{|l|c|c|c|c|c|}
\hline EEM & $\begin{array}{c}\text { Electrical } \\
\text { Savings } \\
(\mathrm{kWh} / \mathrm{yr})\end{array}$ & $\begin{array}{c}\text { Thermal } \\
\text { Savings } \\
(\text { Mil. Btu/yr) }\end{array}$ & $\begin{array}{c}\text { Annual Cost } \\
\text { Savings }\end{array}$ & $\begin{array}{c}\text { Implementation } \\
\text { Costs }\end{array}$ & $\begin{array}{c}\text { Payback } \\
\text { Period (yrs) }\end{array}$ \\
\hline Reduce Infiltration & 28,971 & 0 & $\$ 2,720$ & $\$ 5,516$ & 2.0 \\
\hline Wall Insulation & 36,954 & 0 & $\$ 3,470$ & $\$ 17,232$ & 5.0 \\
\hline Roof/Attic Insulation & 16,039 & 0 & $\$ 1,506$ & $\$ 27,429$ & 18.2 \\
\hline Replace Mechanical Equipment Controls & 281,353 & -1 & $\$ 26,411$ & $\$ 2,760$ & 0.1 \\
\hline Total & 363,317 & -1 & $\$ 34,108$ & 52,938 & 1.6 \\
\hline
\end{tabular}


Table 23. Bldg. 441, savings and payback summary, Climate Zone 5A (Chicago, IL).

\begin{tabular}{|l|c|c|c|c|c|}
\hline EEM & $\begin{array}{c}\text { Electrical } \\
\text { Savings } \\
(\mathbf{k W h} / \mathbf{y r})\end{array}$ & $\begin{array}{c}\text { Thermal } \\
\text { Savings } \\
(\text { Mil. Btu/yr) }\end{array}$ & $\begin{array}{c}\text { Annual Cost } \\
\text { Savings }\end{array}$ & $\begin{array}{c}\text { Implementation } \\
\text { Costs }\end{array}$ & $\begin{array}{c}\text { Payback } \\
\text { Period (yrs) }\end{array}$ \\
\hline Reduce Infiltration & 48,056 & 0 & $\$ 4,512$ & $\$ 5,516$ & 1.2 \\
\hline Wall Insulation & 61,384 & 0 & $\$ 5,764$ & $\$ 17,232$ & 3.0 \\
\hline Roof/Attic Insulation & 23,065 & 0 & $\$ 2,166$ & $\$ 27,429$ & 12.7 \\
\hline Replace Mechanical Equipment Controls & 357,152 & -1 & $\$ 33,529$ & $\$ 2,760$ & 0.1 \\
\hline Total & $\mathbf{4 8 9 , 6 5 7}$ & -1 & $\$ 45,971$ & $\mathbf{5 2 , 9 3 8}$ & 1.2 \\
\hline
\end{tabular}

Table 24. Bldg. 441, savings and payback summary, Climate Zone 5B (Colorado Springs, CO).

\begin{tabular}{|l|c|c|c|c|c|}
\hline EEM & $\begin{array}{c}\text { Electrical } \\
\text { Savings } \\
(\mathbf{k W h} / \mathbf{y r})\end{array}$ & $\begin{array}{c}\text { Thermal } \\
\text { Savings } \\
(\text { Mil. Btu/yr) }\end{array}$ & $\begin{array}{c}\text { Annual Cost } \\
\text { Savings }\end{array}$ & $\begin{array}{c}\text { Implementation } \\
\text { Costs }\end{array}$ & $\begin{array}{c}\text { Payback } \\
\text { Period (yrs) }\end{array}$ \\
\hline Reduce Infiltration & 30,941 & 0 & $\$ 2,905$ & $\$ 5,516$ & 1.9 \\
\hline Wall Insulation & 51,408 & 0 & $\$ 4,827$ & $\$ 17,232$ & 3.6 \\
\hline Roof/Attic Insulation & 24,743 & 0 & $\$ 2,323$ & $\$ 27,429$ & 11.8 \\
\hline Replace Mechanical Equipment Controls & 367,934 & -1 & $\$ 34,541$ & $\$ 2,760$ & 0.1 \\
\hline Total & $\mathbf{4 7 5 , 0 2 6}$ & -1 & $\$ 44,597$ & $\mathbf{5 2 , 9 3 8}$ & 1.2 \\
\hline
\end{tabular}

Table 25. Bldg. 441, savings and payback summary, Climate Zone 6A (Burlington, VT).

\begin{tabular}{|l|c|c|c|c|c|}
\hline EEM & $\begin{array}{c}\text { Electrical } \\
\text { Savings } \\
(\mathbf{k W h} / \mathbf{y r})\end{array}$ & $\begin{array}{c}\text { Thermal } \\
\text { Savings } \\
\text { (Mil. Btu/yr) }\end{array}$ & $\begin{array}{c}\text { Annual Cost } \\
\text { Savings }\end{array}$ & $\begin{array}{c}\text { Implementation } \\
\text { Costs }\end{array}$ & $\begin{array}{c}\text { Payback } \\
\text { Period (yrs) }\end{array}$ \\
\hline Reduce Infiltration & 59,456 & 0 & $\$ 5,583$ & $\$ 5,516$ & 1.0 \\
\hline Wall Insulation & 72,086 & 0 & $\$ 6,769$ & $\$ 17,232$ & 2.5 \\
\hline Roof/Attic Insulation & 27,086 & 0 & $\$ 2,543$ & $\$ 27,429$ & 10.8 \\
\hline Replace Mechanical Equipment Controls & 389,282 & -1 & $\$ 36,546$ & $\$ 2,760$ & 0.1 \\
\hline Total & $\mathbf{5 4 7 , 9 1 0}$ & -1 & $\$ 51,441$ & 52,938 & 1.0 \\
\hline
\end{tabular}

Table 26. Bldg. 441, savings and payback summary, Climate Zone 6B (Helena, MT).

\begin{tabular}{|l|c|c|c|c|c|}
\hline \multicolumn{1}{|c|}{ EEM } & $\begin{array}{c}\text { Electrical } \\
\text { Savings } \\
(\mathbf{k W h} / \mathbf{y r})\end{array}$ & $\begin{array}{c}\text { Thermal } \\
\text { Savings } \\
(\text { Mil. Btu/yr) }\end{array}$ & $\begin{array}{c}\text { Annual Cost } \\
\text { Savings }\end{array}$ & $\begin{array}{c}\text { Implementation } \\
\text { Costs }\end{array}$ & $\begin{array}{c}\text { Payback } \\
\text { Period (yrs) }\end{array}$ \\
\hline Reduce Infiltration & 49,461 & 0 & $\$ 4,644$ & $\$ 5,516$ & 1.2 \\
\hline Wall Insulation & 67,896 & 0 & $\$ 6,375$ & $\$ 17,232$ & 2.7 \\
\hline Roof/Attic Insulation & 29,256 & 0 & $\$ 2,747$ & $\$ 27,429$ & 10.0 \\
\hline Replace Mechanical Equipment Controls & 385,012 & -1 & $\$ 36,145$ & $\$ 2,760$ & 0.1 \\
\hline Total & 531,625 & -1 & $\$ 49,912$ & 52,938 & 1.1 \\
\hline
\end{tabular}


Table 27. Bldg. 441, savings and payback summary, Climate Zone 7A (Duluth, MN).

\begin{tabular}{|c|c|c|c|c|c|}
\hline EEM & $\begin{array}{c}\text { Electrical } \\
\text { Savings } \\
(\mathrm{kWh} / \mathrm{yr})\end{array}$ & $\begin{array}{c}\text { Thermal } \\
\text { Savings } \\
\text { (Mil. Btu/yr) }\end{array}$ & $\begin{array}{c}\text { Annual Cost } \\
\text { Savings }\end{array}$ & $\begin{array}{l}\text { Implementation } \\
\text { Costs }\end{array}$ & $\begin{array}{l}\text { Payback } \\
\text { Period (yrs) }\end{array}$ \\
\hline Reduce Infiltration & 72,028 & 0 & $\$ 6,763$ & $\$ 5,516$ & 0.8 \\
\hline Wall Insulation & 96,047 & 0 & $\$ 9,019$ & $\$ 17,232$ & 1.9 \\
\hline Roof/Attic Insulation & 37,469 & 0 & $\$ 3,518$ & $\$ 27,429$ & 7.8 \\
\hline $\begin{array}{l}\text { Replace Mechanical Equipment } \\
\text { Controls }\end{array}$ & 449,935 & -1 & $\$ 42,241$ & $\$ 2,760$ & 0.1 \\
\hline Total & 655,479 & -1 & $\$ 61,542$ & 52,938 & 0.9 \\
\hline
\end{tabular}

Table 28. Bldg. 441, savings and payback summary, Climate Zone 8 A (Fairbanks, AK).

\begin{tabular}{|l|c|c|c|c|c|}
\hline EEM & $\begin{array}{c}\text { Electrical } \\
\text { Savings } \\
(\mathbf{k W h} / \mathbf{y r})\end{array}$ & $\begin{array}{c}\text { Thermal } \\
\text { Savings } \\
(\mathrm{Mil} \text {. Btu/yr) }\end{array}$ & $\begin{array}{c}\text { Annual Cost } \\
\text { Savings }\end{array}$ & $\begin{array}{c}\text { Implementation } \\
\text { Costs }\end{array}$ & $\begin{array}{c}\text { Payback } \\
\text { Period (yrs) }\end{array}$ \\
\hline Reduce Infiltration & 112,783 & 0 & $\$ 10,590$ & $\$ 5,516$ & 0.5 \\
\hline Wall Insulation & 134,468 & 0 & $\$ 12,627$ & $\$ 17,232$ & 1.4 \\
\hline Roof/Attic Insulation & 61,208 & 0 & $\$ 5,747$ & $\$ 27,429$ & 4.8 \\
\hline Replace Mechanical Equipment Controls & 579,040 & -1 & $\$ 54,364$ & $\$ 2,760$ & 0.1 \\
\hline Total & $\mathbf{8 8 7 , 4 9 9}$ & -1 & $\$ 83,328$ & $\mathbf{5 2 , 9 3 8}$ & 0.6 \\
\hline
\end{tabular}

Figure 8. Bldg. 441, annual cost savings resulting from EEM “Reduce Infiltration," by climate zone.

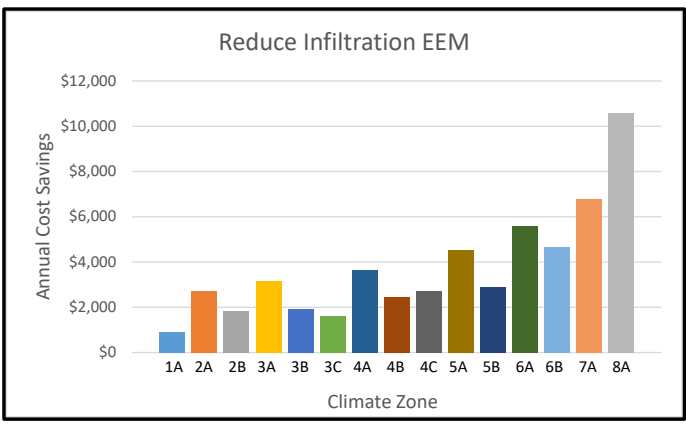

Figure 10. Bldg. 441, annual cost savings resulting from EEM “Wall Insulation," by climate zone.

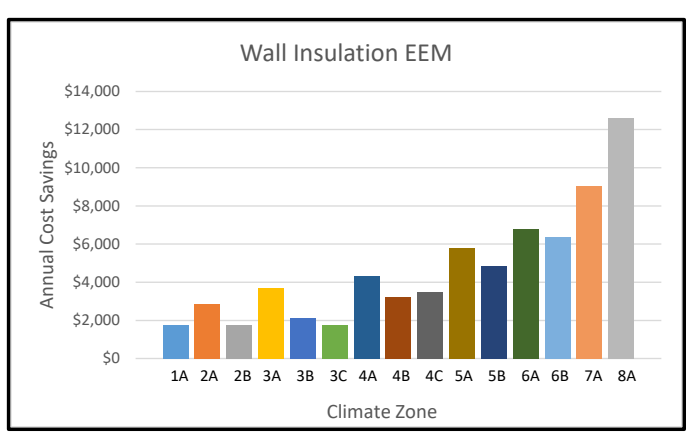

Figure 9. Bldg. 441, simple payback resulting from EEM “Reduce Infiltration,” by climate

zone.

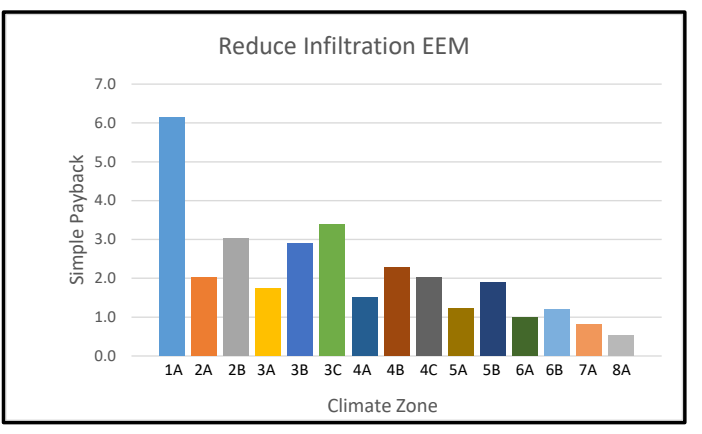

Figure 11. Bldg. 441, simple payback resulting from EEM “Wall Insulation," by climate zone.

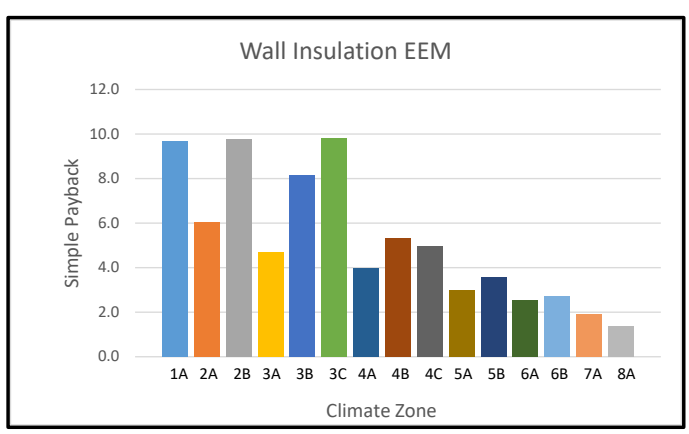


Figure 12. Bldg. 441, annual cost savings resulting from EEM “Roof/Attic Insulation," by climate zone.

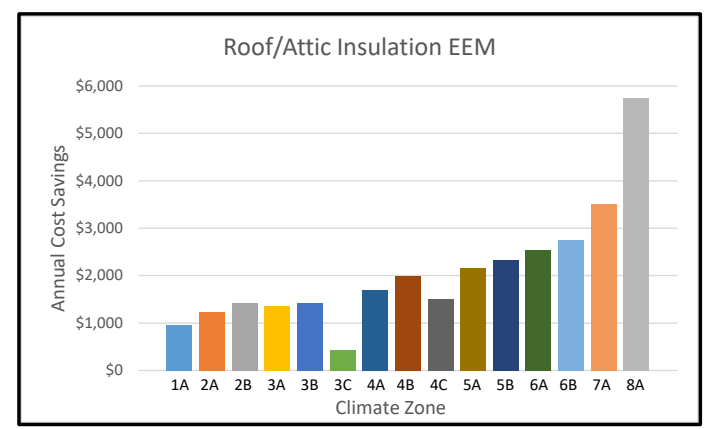

Figure 14. Bldg. 441, annual cost savings resulting from EEM "Replace Mechanical Equipment Controls EEM," by climate zone.

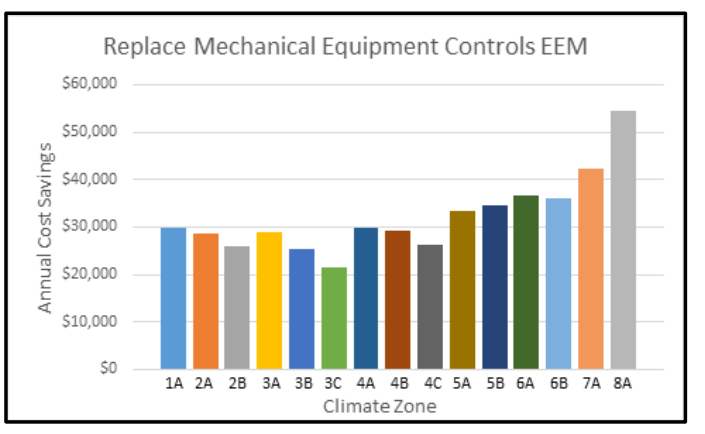

Figure 13. Bldg. 441, simple payback resulting from EEM “Roof/Attic Insulation," by climate zone.

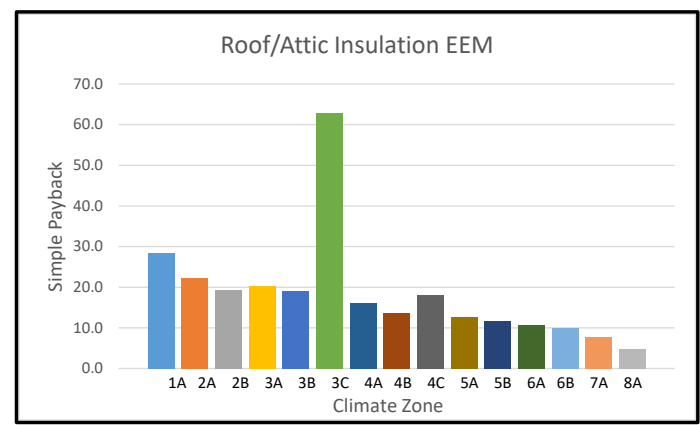

Figure 15. Bldg. 441, simple payback resulting from EEM “Replace Mechanical Equipment Controls EEM," by climate zone.

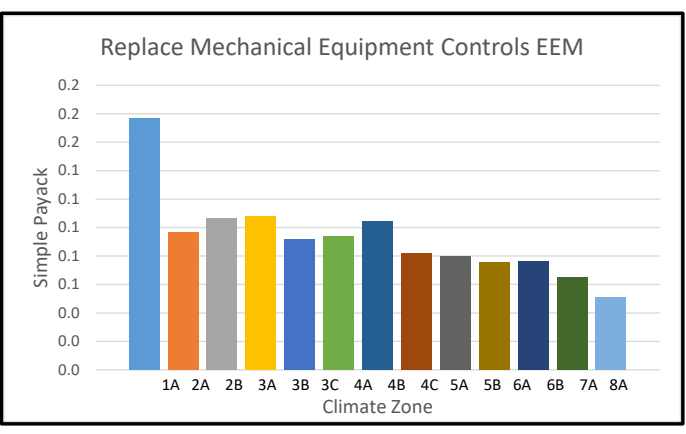

\subsubsection{BIdg. 462 EEM savings by climate zone}

The EEMs chosen for Bldg. 462 were:

- Reduce Infiltration. Infiltration of the building was changed from 2.00 $\mathrm{ACH}$ to 1.00 ACH. The implementation cost was calculated from 48 windows that are $4 \times 7 \mathrm{ft}, 143$ windows that are $3.33 \times 4.17 \mathrm{ft}$, and 15 doors that are $3 \times 6 \mathrm{ft}$ for a total of $3381 \mathrm{ft}$ of weatherstripping, at a cost of $\$ 4.41 / \mathrm{ft}$.

- Roof/Attic Insulation. Add R-38 batt insulation plus radiant barrier to the roof, where previously there was no insulation. The cost of this insulation was estimated using RSMeans. The cost of the insulation was found to be $\$ 1.93 / \mathrm{ft}^{2}$ in 2014 , to which an escalation of $3 \%$ per year was added. With $8,076 \mathrm{ft}^{2}$ of roof/attic area, the estimated cost is $\$ 17,117$.

- Replace Mechanical Equipment. Replace the building's 88\% efficiency boiler with a boiler that is $95 \%$ efficient. Using RSMeans, the costs to replace a 2,000 $\mathrm{MBH}$ boiler, is estimated at $\$ 29,900$ for equipment and $\$ 7,475$ for labor, summing to a total cost of $\$ 37,375$. 
- Replace Mechanical Equipment Controls. Change the building from an occupancy of $24 \mathrm{hrs}$ per day every day of the week to an occupancy of 0700-1700 M-F, and unoccupied Sa-Su and on Holidays. It also changed the temperature setpoints from occupied and unoccupied cooling and heating of 74 and $72{ }^{\circ} \mathrm{F}$, to occupied cooling and heating of 78 and $68{ }^{\circ} \mathrm{F}$ and unoccupied cooling and heating of 85 and $55^{\circ} \mathrm{F}$, respectively. The HVAC system fans were set to operate 2 hours before open and 2 hours after close of the building.

A time clock for each air handling unit (AHU) and labor can be used to achieve the above recommendations. A cost of $\$ 3,900$ for the time clock and $\$ 1,392$ of fixed labor (based on previous experience) was assumed. For the three AHUs, this is a total cost of $\$ 15,876$.

- Lighting Controls. Energy audits of this facility indicated a large number of open areas that had potential for savings via occupancy sensors. A cost of $\$ 0.95 / \mathrm{ft}^{2}$ was used based on Zhang et al. (2013). With a facility area of $33,425 \mathrm{ft}^{2}$, the estimated cost is $\$ 31,754$.

The model was then run in each of the different climate zones using eQUEST. The results are listed in Tables 29-43 and shown in Figures 16-25.

Table 29. Bldg. 462, savings and payback summary, Climate Zone $1 \mathrm{~A}$ (Miami, FL).

\begin{tabular}{|l|c|c|c|c|c|}
\hline EEM & $\begin{array}{c}\text { Electrical } \\
\text { Savings } \\
(\mathbf{k W h} / \mathbf{y r})\end{array}$ & $\begin{array}{c}\text { Thermal } \\
\text { Savings } \\
\mathbf{( M i l .} \\
\text { Btu/yr) }\end{array}$ & $\begin{array}{c}\text { Annual Cost } \\
\text { Savings }\end{array}$ & $\begin{array}{c}\text { Implementation } \\
\text { Costs }\end{array}$ & $\begin{array}{c}\text { Payback } \\
\text { Period (yrs) }\end{array}$ \\
\hline Reduce Infiltration & 35,677 & 45 & $\$ 3,700$ & $\$ 14,910.21$ & 4.0 \\
\hline Lighting Controls & 12,357 & & $\$ 1,160$ & $\$ 31,754$ & 27.4 \\
\hline Roof/Attic Insulation & 1,669 & 0 & $\$ 157$ & $\$ 17,117.41$ & 109.2 \\
\hline Replacement of Mechanical Equipment & 0 & 48 & $\$ 373$ & $\$ 37,375$ & 100.1 \\
\hline Replace Mechanical Equipment Controls & 519,582 & 618 & $\$ 53,597$ & $\$ 15,876$ & 0.3 \\
\hline Total & $\mathbf{5 6 9 , 2 8 5}$ & $\mathbf{7 1 1}$ & $\$ 58,987$ & $\$ 117,032.37$ & 2.0 \\
\hline
\end{tabular}

Table 30. Bldg. 462, savings and payback summary, Climate Zone 2A (Houston, TX).

\begin{tabular}{|l|c|c|c|c|c|}
\hline & $\begin{array}{c}\text { Electrical } \\
\text { Savings } \\
\text { EEM }\end{array}$ & $\begin{array}{c}\text { Thermal } \\
\text { Savings } \\
\text { (Mil. } \\
\text { Btu/yr) }\end{array}$ & $\begin{array}{c}\text { Annual Cost } \\
\text { Savings }\end{array}$ & $\begin{array}{c}\text { Implementation } \\
\text { Costs }\end{array}$ & $\begin{array}{c}\text { Payback } \\
\text { Period (yrs) }\end{array}$ \\
\hline Reduce Infiltration & 56,341 & 457 & $\$ 8,846$ & $\$ 14,910$ & 1.7 \\
\hline Lighting Controls & 12,357 & & $\$ 1,160$ & $\$ 31,754$ & 27.4 \\
\hline Roof/Attic Insulation & 1,331 & 6 & $\$ 172$ & $\$ 17,117$ & 99.7 \\
\hline Replacement of Mechanical Equipment & 0 & 142 & $\$ 1,105$ & $\$ 37,375$ & 33.8 \\
\hline Replace Mechanical Equipment Controls & 462,042 & 1,393 & $\$ 54,223$ & $\$ 15,876$ & 0.3 \\
\hline Total & 532,071 & 1,998 & $\$ 65,506$ & 117,032 & 1.8 \\
\hline
\end{tabular}


Table 31. Bldg. 462, savings and payback summary, Climate Zone 2B (Phoenix, AZ).

\begin{tabular}{|l|c|c|c|c|c|}
\hline EEM & $\begin{array}{c}\text { Electrical } \\
\text { Savings } \\
(\mathrm{kWh} / \mathbf{y r})\end{array}$ & $\begin{array}{c}\text { Thermal } \\
\text { Savings } \\
\text { (Mil. } \\
\text { Btu/yr) }\end{array}$ & $\begin{array}{c}\text { Annual Cost } \\
\text { Savings }\end{array}$ & $\begin{array}{c}\text { Implementation } \\
\text { Costs }\end{array}$ & $\begin{array}{c}\text { Payback } \\
\text { Period (yrs) }\end{array}$ \\
\hline Reduce Infiltration & 29,021 & 234 & $\$ 4,546$ & $\$ 14,910$ & 3.3 \\
\hline Lighting Controls & 12,357 & & $\$ 1,160$ & $\$ 31,754$ & 27.4 \\
\hline Roof/Attic Insulation & 3,339 & 10 & $\$ 391$ & $\$ 17,117$ & 43.7 \\
\hline Replacement of Mechanical Equipment & 0 & 104 & $\$ 809$ & $\$ 37,375$ & 46.2 \\
\hline Replace Mechanical Equipment Controls & 445,698 & 1,102 & $\$ 50,425$ & $\$ 15,876$ & 0.3 \\
\hline Total & 490,415 & 1,450 & $\$ 57,331$ & 117,032 & 2.0 \\
\hline
\end{tabular}

Table 32. Bldg. 462, savings and payback summary, Climate Zone 3A (Memphis, TN).

\begin{tabular}{|l|c|c|c|c|c|}
\hline EEM & $\begin{array}{c}\text { Electrical } \\
\text { Savings } \\
(\mathrm{kWh} / \mathrm{yr})\end{array}$ & $\begin{array}{c}\text { Thermal } \\
\text { Savings } \\
\mathbf{( M i l .} \\
\text { Btu/yr) }\end{array}$ & $\begin{array}{c}\text { Annual Cost } \\
\text { Savings }\end{array}$ & $\begin{array}{c}\text { Implementation } \\
\text { Costs }\end{array}$ & $\begin{array}{c}\text { Payback } \\
\text { Period (yrs) }\end{array}$ \\
\hline Reduce Infiltration & 74,264 & 808 & $\$ 13,260$ & $\$ 14,910$ & 1.1 \\
\hline Lighting Controls & 12,357 & & $\$ 1,160$ & $\$ 31,754$ & 27.4 \\
\hline Roof/Attic Insulation & 1,146 & 9 & $\$ 178$ & $\$ 17,117$ & 96.4 \\
\hline Replacement of Mechanical Equipment & 0 & 218 & $\$ 1,696$ & $\$ 37,375$ & 22.0 \\
\hline Replace Mechanical Equipment Controls & 437,607 & 1,983 & $\$ 56,519$ & $\$ 15,876$ & 0.3 \\
\hline Total & 525,374 & 3,018 & $\$ 72,813$ & 117,032 & 1.6 \\
\hline
\end{tabular}

Table 33. Bldg. 462, savings and payback summary, Climate Zone 3B (El Paso, TX).

\begin{tabular}{|c|c|c|c|c|c|}
\hline EEM & $\begin{array}{c}\text { Electrical } \\
\text { Savings } \\
\text { (kWh/yr) }\end{array}$ & $\begin{array}{c}\text { Thermal } \\
\text { Savings } \\
\text { (Mil. } \\
\text { Btu/yr) }\end{array}$ & $\begin{array}{c}\text { Annual Cost } \\
\text { Savings }\end{array}$ & $\begin{array}{l}\text { Implementation } \\
\text { Costs }\end{array}$ & $\begin{array}{l}\text { Payback } \\
\text { Period (yrs) }\end{array}$ \\
\hline Reduce Infiltration & 29,578 & 424 & $\$ 6,076$ & $\$ 14,910$ & 2.5 \\
\hline Lighting Controls & 12,357 & & $\$ 1,160$ & $\$ 31,754$ & 27.4 \\
\hline Roof/Attic Insulation & 2,090 & 11 & $\$ 282$ & $\$ 17,117$ & 60.7 \\
\hline Replacement of Mechanical Equipment & 0 & 159 & $\$ 1,237$ & $\$ 37,375$ & 30.2 \\
\hline Replace Mechanical Equipment Controls & 389,094 & 1,544 & $\$ 48,548$ & $\$ 15,876$ & 0.3 \\
\hline Total & 433,119 & 2,138 & $\$ 57,304$ & 117,032 & 2.0 \\
\hline
\end{tabular}

Table 34. Bldg. 462, savings and payback summary, Climate Zone 3C (San Francisco, CA).

\begin{tabular}{|l|c|c|c|c|c|}
\hline & $\begin{array}{c}\text { Electrical } \\
\text { Savings } \\
(\mathrm{kWh} / \mathrm{yr})\end{array}$ & $\begin{array}{c}\text { Thermal } \\
\text { Savings } \\
\text { (Mil. } \\
\text { Btu/yr) }\end{array}$ & $\begin{array}{c}\text { Annual Cost } \\
\text { Savings }\end{array}$ & $\begin{array}{c}\text { Implementation } \\
\text { Costs }\end{array}$ & $\begin{array}{c}\text { Payback } \\
\text { Period (yrs) }\end{array}$ \\
\hline Reduce Infiltration & 26,781 & 628 & $\$ 7,401$ & $\$ 14,910$ & 2.0 \\
\hline Lighting Controls & 12,357 & & $\$ 1,160$ & $\$ 31,754$ & 27.4 \\
\hline Roof/Attic Insulation & 574 & 12 & $\$ 147$ & $\$ 17,117$ & 116.2 \\
\hline Replacement of Mechanical Equipment & 0 & 201 & $\$ 1,564$ & $\$ 37,375$ & 23.9 \\
\hline Replace Mechanical Equipment Controls & 318,221 & 1,855 & $\$ 44,313$ & $\$ 15,876$ & 0.4 \\
\hline Total & 357,933 & 2,696 & $\$ 54,585$ & 117,032 & 2.1 \\
\hline
\end{tabular}


Table 35. Bldg. 462, savings and payback summary, Climate Zone 4A (Baltimore, MD).

\begin{tabular}{|l|c|c|c|c|c|}
\hline EEM & $\begin{array}{c}\text { Electrical } \\
\text { Savings } \\
(\mathrm{kWh} / \mathrm{yr})\end{array}$ & $\begin{array}{c}\text { Thermal } \\
\text { Savings } \\
\mathbf{( M i l .} \\
\text { Btu/yr) }\end{array}$ & $\begin{array}{c}\text { Annual Cost } \\
\text { Savings }\end{array}$ & $\begin{array}{c}\text { Implementation } \\
\text { Costs }\end{array}$ & $\begin{array}{c}\text { Payback } \\
\text { Period (yrs) }\end{array}$ \\
\hline Reduce Infiltration & 81,510 & 1,094 & $\$ 16,165$ & $\$ 14,910$ & 0.9 \\
\hline Lighting Controls & 12,357 & & $\$ 1,160$ & $\$ 31,754$ & 27.4 \\
\hline Roof/Attic Insulation & 1,660 & 9.1 & $\$ 227$ & $\$ 17,117$ & 75.5 \\
\hline Replacement of Mechanical Equipment & 0 & 309 & $\$ 2,404$ & $\$ 37,375$ & 15.5 \\
\hline Replace Mechanical Equipment Controls & 414,817 & 2,613 & $\$ 59,280$ & $\$ 15,876$ & 0.3 \\
\hline Total & 509,344 & $\mathbf{4 , 1 0 7}$ & $\$ 79,780$ & 117,032 & 1.5 \\
\hline
\end{tabular}

Table 36. Bldg. 462, savings and payback summary, Climate Zone 4B (Albuquerque, NM).

\begin{tabular}{|c|c|c|c|c|c|}
\hline EEM & $\begin{array}{c}\text { Electrical } \\
\text { Savings } \\
\text { (kWh/yr) }\end{array}$ & $\begin{array}{c}\text { Thermal } \\
\text { Savings (Mil. } \\
\text { Btu/yr) }\end{array}$ & $\begin{array}{c}\text { Annual Cost } \\
\text { Savings }\end{array}$ & $\begin{array}{l}\text { Implementation } \\
\text { Costs }\end{array}$ & $\begin{array}{l}\text { Payback } \\
\text { Period (yrs) }\end{array}$ \\
\hline Reduce Infiltration & 34,966 & 631 & $\$ 8,192$ & $\$ 14,910$ & 1.8 \\
\hline Lighting Controls & 12,357 & & $\$ 1,160$ & $\$ 31,754$ & 27.4 \\
\hline Roof/Attic Insulation & 1,261 & 9 & $\$ 188$ & $\$ 17,117$ & 90.8 \\
\hline Replacement of Mechanical Equipment & 0 & 231 & $\$ 1,797$ & $\$ 37,375$ & 20.8 \\
\hline Replace Mechanical Equipment Controls & 356,946 & 2,015 & $\$ 49,194$ & $\$ 15,876$ & 0.3 \\
\hline Total & 405,530 & 2,886 & $\$ 60,532$ & 117,032 & 1.9 \\
\hline
\end{tabular}

Table 37. Bldg. 462, savings and payback summary, Climate Zone 4C (Seattle, WA).

\begin{tabular}{|l|c|c|c|c|c|}
\hline EEM & $\begin{array}{c}\text { Electrical } \\
\text { Savings } \\
(\mathrm{kWh} / \mathrm{yr})\end{array}$ & $\begin{array}{c}\text { Thermal } \\
\text { Savings (Mil. } \\
\text { Btu/yr) }\end{array}$ & $\begin{array}{c}\text { Annual Cost } \\
\text { Savings }\end{array}$ & $\begin{array}{c}\text { Implementation } \\
\text { Costs }\end{array}$ & $\begin{array}{c}\text { Payback } \\
\text { Period (yrs) }\end{array}$ \\
\hline Reduce Infiltration & 38,440 & 809 & $\$ 9,904$ & $\$ 14,910$ & 1.5 \\
\hline Lighting Controls & 12,357 & & $\$ 1,160$ & $\$ 31,754$ & 27.4 \\
\hline Roof/Attic Insulation & 531 & 12 & $\$ 143$ & $\$ 17,117$ & 119.5 \\
\hline Replacement of Mechanical Equipment & 0 & 274 & $\$ 2,132$ & $\$ 37,375$ & 17.5 \\
\hline Replace Mechanical Equipment Controls & 330,218 & 2,233 & $\$ 48,380$ & $\$ 15,876$ & 0.3 \\
\hline Total & 381,546 & 3,328 & $\$ 61,719$ & 117,032 & 1.9 \\
\hline
\end{tabular}

Table 38. Bldg. 462, savings and payback summary, Climate Zone 5A (Chicago, IL).

\begin{tabular}{|l|c|c|c|c|c|}
\hline & $\begin{array}{c}\text { Electrical } \\
\text { Savings } \\
(\mathbf{k W h} / \mathbf{y r})\end{array}$ & $\begin{array}{c}\text { Thermal } \\
\text { Savings (Mil. } \\
\text { Btu/yr) }\end{array}$ & $\begin{array}{c}\text { Annual Cost } \\
\text { Savings }\end{array}$ & $\begin{array}{c}\text { Implementation } \\
\text { Costs }\end{array}$ & $\begin{array}{c}\text { Payback } \\
\text { Period (yrs) }\end{array}$ \\
\hline Reduce Infiltration & 141,630 & 1,801 & $\$ 27,311$ & $\$ 14,910$ & 0.5 \\
\hline Lighting Controls & 12,357 & & $\$ 1,160$ & $\$ 31,754$ & 27.4 \\
\hline Roof/Attic Insulation & 465 & 10 & $\$ 121$ & $\$ 17,117$ & 140.9 \\
\hline Replacement of Mechanical Equipment & 0 & 443 & $\$ 3,447$ & $\$ 37,375$ & 10.8 \\
\hline Replace Mechanical Equipment Controls & 465,678 & 3,637 & $\$ 72,023$ & $\$ 15,876$ & 0.2 \\
\hline Total & 620,130 & 5,891 & $\$ 104,062$ & 117,032 & 1.1 \\
\hline
\end{tabular}


Table 39. BIdg. 462, savings and payback summary, Climate Zone 5B (Colorado Springs, CO).

\begin{tabular}{|l|c|c|c|c|c|}
\hline EEM & $\begin{array}{c}\text { Electrical } \\
\text { Savings } \\
(\mathbf{k W h} / \mathbf{y r})\end{array}$ & $\begin{array}{c}\text { Thermal } \\
\text { Savings (Mil. } \\
\text { Btu/yr) }\end{array}$ & $\begin{array}{c}\text { Annual Cost } \\
\text { Savings }\end{array}$ & $\begin{array}{c}\text { Implementation } \\
\text { Costs }\end{array}$ & $\begin{array}{c}\text { Payback } \\
\text { Period (yrs) }\end{array}$ \\
\hline Reduce Infiltration & 96,944 & 1,329 & $\$ 19,443$ & $\$ 14,910$ & 0.8 \\
\hline Lighting Controls & 12,357 & & $\$ 1,160$ & $\$ 31,754$ & 27.4 \\
\hline Roof/Attic Insulation & 579 & 13 & $\$ 156$ & $\$ 17,117$ & 110.1 \\
\hline Replacement of Mechanical Equipment & 0 & 368 & $\$ 2,863$ & $\$ 37,375$ & 13.1 \\
\hline Replace Mechanical Equipment Controls & 402,490 & 3,150 & $\$ 62,301$ & $\$ 15,876$ & 0.3 \\
\hline Total & 512,370 & 4,860 & $\$ 85,922$ & 117,032 & 1.4 \\
\hline
\end{tabular}

Table 40. Bldg. 462, savings and payback summary, Climate Zone 6A (Burlington, VT).

\begin{tabular}{|l|c|c|c|c|c|}
\hline EEM & $\begin{array}{c}\text { Electrical } \\
\text { Savings } \\
(\mathbf{k W h} / \mathbf{y r})\end{array}$ & $\begin{array}{c}\text { Thermal } \\
\text { Savings (Mil. } \\
\text { Btu/yr) }\end{array}$ & $\begin{array}{c}\text { Annual Cost } \\
\text { Savings }\end{array}$ & $\begin{array}{c}\text { Implementation } \\
\text { Costs }\end{array}$ & $\begin{array}{c}\text { Payback } \\
\text { Period (yrs) }\end{array}$ \\
\hline Reduce Infiltration & 143,854 & 1,950 & $\$ 28,679$ & $\$ 14,910$ & 0.5 \\
\hline Lighting Controls & 12,357 & & $\$ 1,160$ & $\$ 31,754$ & 27.4 \\
\hline Roof/Attic Insulation & 354 & 13 & $\$ 134$ & $\$ 17,117$ & 127.4 \\
\hline Replacement of Mechanical Equipment & 0 & 488 & $\$ 3,797$ & $\$ 37,375$ & 9.8 \\
\hline Replace Mechanical Equipment Controls & 454,676 & 3,872 & $\$ 72,818$ & $\$ 15,876$ & 0.2 \\
\hline Total & 611,241 & 6,323 & $\$ 106,588$ & 117,032 & 1.1 \\
\hline
\end{tabular}

Table 41. Bldg. 462, savings and payback summary, Climate Zone 6B (Helena, MT).

\begin{tabular}{|l|c|c|c|c|c|}
\hline EEM & $\begin{array}{c}\text { Electrical } \\
\text { Savings } \\
(\mathrm{kWh} / \mathrm{yr})\end{array}$ & $\begin{array}{c}\text { Thermal } \\
\text { Savings (Mil. } \\
\text { Btu/yr) }\end{array}$ & $\begin{array}{c}\text { Annual Cost } \\
\text { Savings }\end{array}$ & $\begin{array}{c}\text { Implementation } \\
\text { Costs }\end{array}$ & $\begin{array}{c}\text { Payback } \\
\text { Period (yrs) }\end{array}$ \\
\hline Reduce Infiltration & 134,638 & 1,835 & $\$ 26,919$ & $\$ 14,910$ & 0.6 \\
\hline Lighting Controls & 12,357 & & $\$ 1,160$ & $\$ 31,754$ & 27.4 \\
\hline Roof/Attic Insulation & 736 & 26 & $\$ 271$ & $\$ 17,117$ & 63.1 \\
\hline Replacement of Mechanical Equipment & 0 & 473 & $\$ 3,680$ & $\$ 37,375$ & 10.2 \\
\hline Replace Mechanical Equipment Controls & 439,507 & 3,797 & $\$ 70,810$ & $\$ 15,876$ & 0.2 \\
\hline Total & 587,238 & 6,131 & $\$ 102,841$ & 117,032 & 1.1 \\
\hline
\end{tabular}

Table 42. Bldg. 462, savings and payback summary, Climate Zone 7A (Duluth, MN).

\begin{tabular}{|l|c|c|c|c|c|}
\hline EEM & $\begin{array}{c}\text { Electrical } \\
\text { Savings } \\
(\mathrm{kWh} / \mathrm{yr})\end{array}$ & $\begin{array}{c}\text { Thermal } \\
\text { Savings (Mil. } \\
\text { Btu/yr) }\end{array}$ & $\begin{array}{c}\text { Annual Cost } \\
\text { Savings }\end{array}$ & $\begin{array}{c}\text { Implementation } \\
\text { Costs }\end{array}$ & $\begin{array}{c}\text { Payback } \\
\text { Period (yrs) }\end{array}$ \\
\hline Reduce Infiltration & 160,431 & 2,286 & $\$ 32,850$ & $\$ 14,910$ & 0.5 \\
\hline Lighting Controls & 12,357 & & $\$ 1,160$ & $\$ 31,754$ & 27.4 \\
\hline Roof/Attic Insulation & 153 & 12 & $\$ 108$ & $\$ 17,117$ & 158.9 \\
\hline Replacement of Mechanical Equipment & 0 & 608 & $\$ 4,730$ & $\$ 37,375$ & 7.9 \\
\hline Replace Mechanical Equipment Controls & 489,107 & 4,778 & $\$ 83,100$ & $\$ 15,876$ & 0.2 \\
\hline Total & 662,048 & 7,684 & $\$ 121,948$ & 117,032 & 1.0 \\
\hline
\end{tabular}


Table 43. Bldg. 462, savings and payback summary, Climate Zone 8A (Fairbanks, AK).

\begin{tabular}{|l|c|c|c|c|c|}
\hline EEM & $\begin{array}{c}\text { Electrical } \\
\text { Savings (kWh/yr) }\end{array}$ & $\begin{array}{c}\text { Thermal } \\
\text { Savings (Mil. } \\
\text { Btu/yr) }\end{array}$ & $\begin{array}{c}\text { Annual Cost } \\
\text { Savings }\end{array}$ & $\begin{array}{c}\text { Implementation } \\
\text { Costs }\end{array}$ & $\begin{array}{c}\text { Payback } \\
\text { Period (yrs) }\end{array}$ \\
\hline Reduce Infiltration & 211,423 & 3,141 & $\$ 44,290$ & $\$ 14,910$ & 0.3 \\
\hline Lighting Controls & 12,357 & & $\$ 1,160$ & $\$ 31,754$ & 27.4 \\
\hline Roof/Attic Insulation & $-1,040$ & 32 & $\$ 151$ & $\$ 17,117$ & 113.1 \\
\hline Replacement of Mechanical Equipment & 0 & 840 & $\$ 6,535$ & $\$ 37,375$ & 5.7 \\
\hline Replace Mechanical Equipment Controls & 557,736 & 5,400 & $\$ 94,383$ & $\$ 15,876$ & 0.2 \\
\hline Total & 780,476 & 9,413 & $\$ 146,520$ & 117,032 & 0.8 \\
\hline
\end{tabular}

Figure 16. Bldg. 462, annual cost savings resulting from EEM “Reduce Infiltration,” by climate zone.

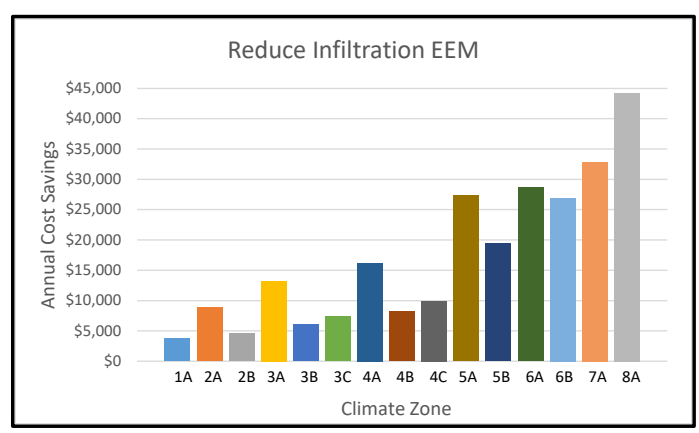

Figure 18. Bldg. 462, annual cost savings resulting from EEM “Lighting Controls," by climate zone.

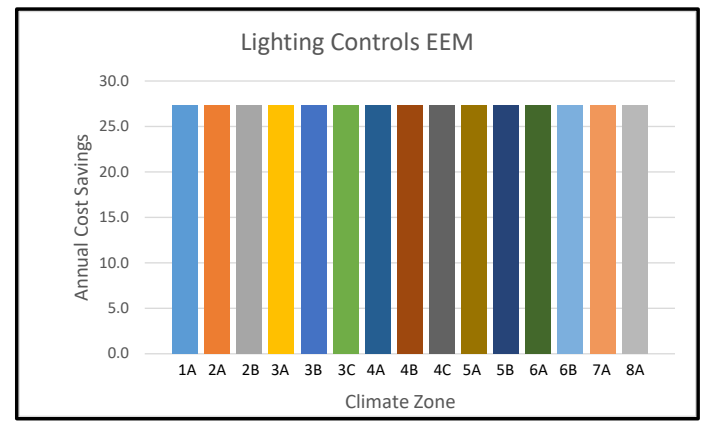

Figure 17. Bldg. 462, simple payback resulting from EEM “Reduce Infiltration," by climate zone.

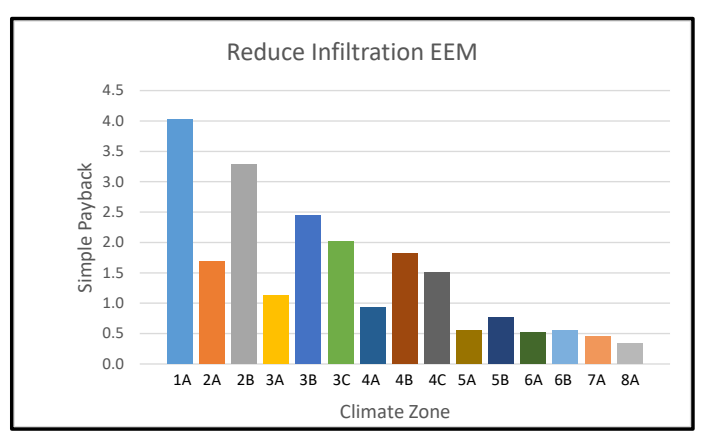

Figure 19. Bldg. 462, simple payback resulting from EEM “Lighting Controls,” by climate zone.

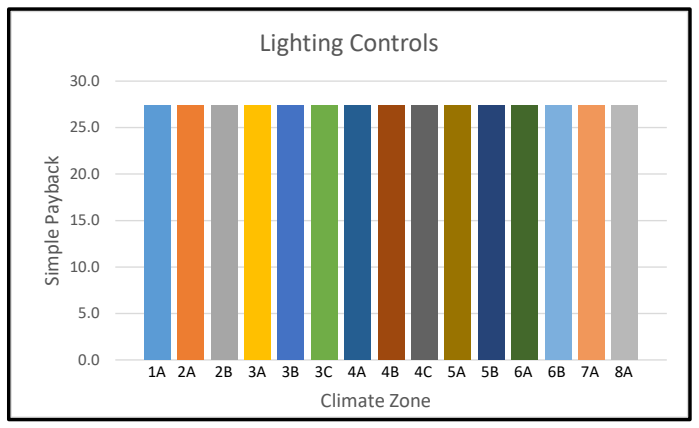


Figure 20. Bldg. 462, annual cost savings resulting from EEM "Roof/Attic Insulation," by climate zone.

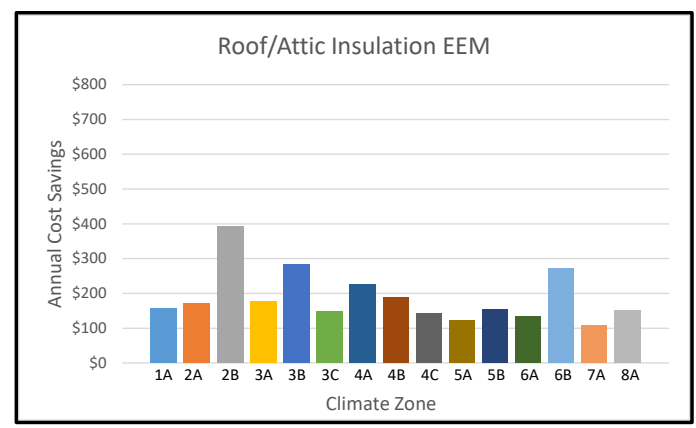

Figure 22. Bldg. 462, annual cost savings resulting from EEM “Replace Mechanical

Equipment EEM," by climate zone.

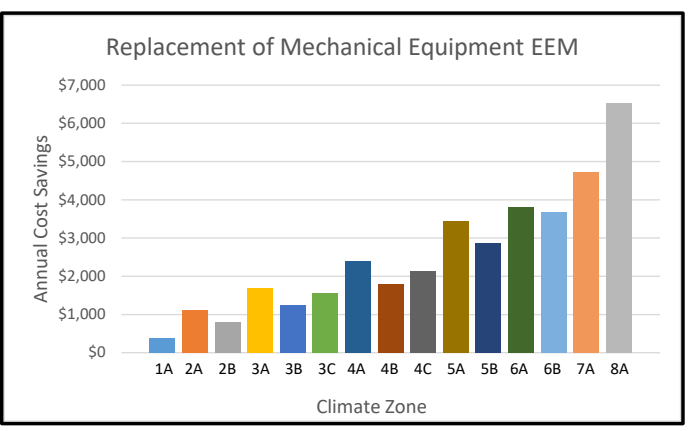

Figure 24. Bldg. 462, annual cost savings resulting from EEM "Replace Mechanical Equipment Controls EEM," by climate zone.

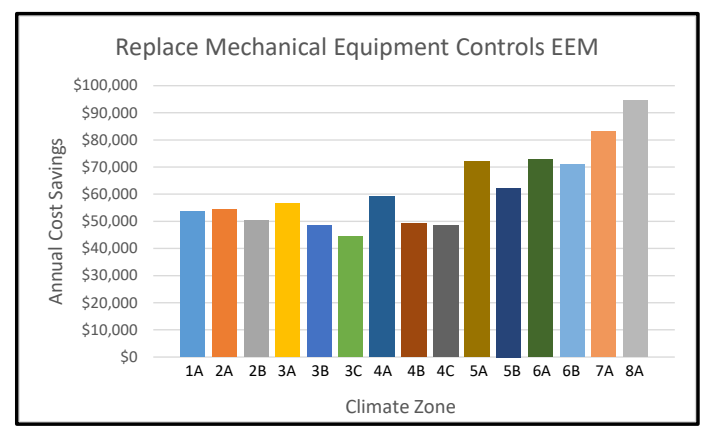

Figure 21. BIdg. 462, simple payback resulting from EEM “Roof/Attic Insulation," by climate zone.

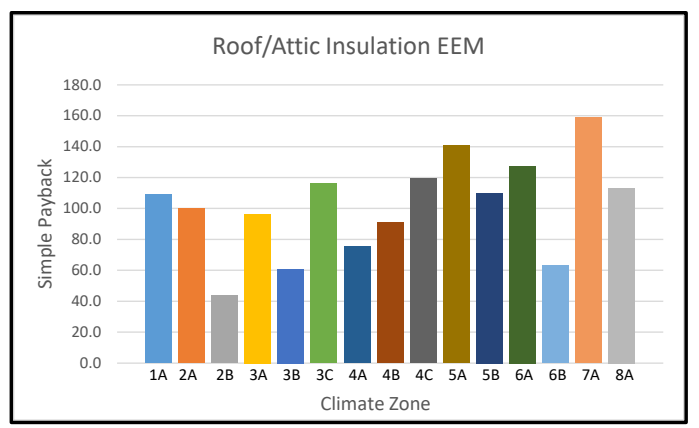

Figure 23. Bldg. 462, simple payback resulting from EEM "Replace Mechanical Equipment EEM," by climate zone.

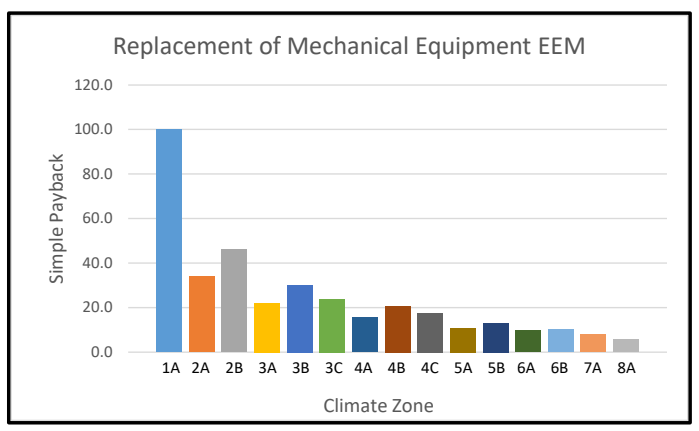

Figure 25. Bldg. 462, simple payback resulting from EEM “Replace Mechanical Equipment Controls EEM," by climate zone.

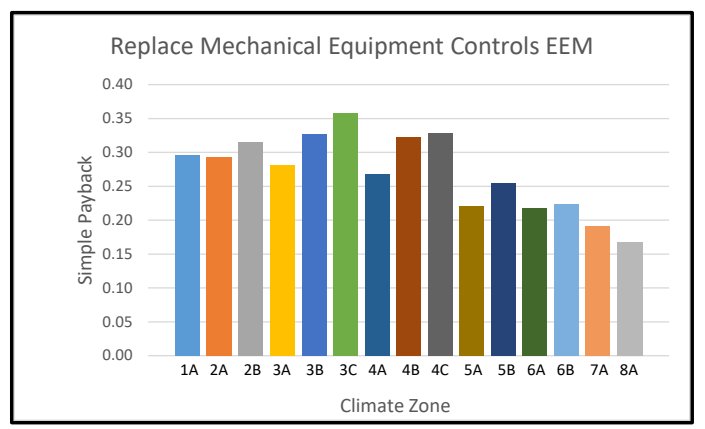




\subsubsection{Bldg. 463 EEM savings by climate zone}

The EEMs chosen for Bldg. 463 were:

- Reduce Infiltration. Infiltration of the building was changed from 2.00 $\mathrm{ACH}$ to 1.00 $\mathrm{ACH}$. The implementation cost was calculated from 355 windows that are $2.5 \times 5.22 \mathrm{ft}$, five doors that are $4 \times 6 \mathrm{ft}$, and one door that is $6 \times 7 \mathrm{ft}$ for a total of $5570.2 \mathrm{ft}$ of weatherstripping, at a cost of $\$ 4.41 / \mathrm{ft}$.

- Roof/Attic Insulation Add R-38 batt insulation to the roof, where previously there was no insulation. The cost of the insulation was found to be $\$ 1.93 / \mathrm{ft}^{2}$ in 2014 , to which an escalation of $3 \%$ per year was added. With 9,085 $\mathrm{ft}^{2}$ of roof/attic area, the estimated cost is $\$ 16,216$.

- Replacement of Mechanical Equipment. Replace the building's $80 \%$ efficiency boiler with a boiler that is $95 \%$ efficient. Using RSMeans, the costs to replace a 1,000 $\mathrm{MBH}$ boiler, is estimated at $\$ 20,100$ for equipment and $\$ 5,025$ for labor, summing to a total cost of $\$ 25,125$.

- Replace Mechanical Equipment Controls. Change the building from an occupancy of $24 \mathrm{hrs}$ per day every day of the week to an occupancy of o800-1700 M-F, and unoccupied Sa-Su and on Holidays. It also changed the temperature setpoints from occupied and unoccupied cooling and heating of 74 and $72{ }^{\circ} \mathrm{F}$, to occupied cooling and heating of 78 and $68^{\circ} \mathrm{F}$ and unoccupied cooling and heating of 85 and $55^{\circ} \mathrm{F}$, respectively. The HVAC system fans were set to operate 2 hours before open and 2 hours after close of the building. The fans were set to cycle at night with minimum Outside Air, to use an economizer, and to cycle on via control zones.

A time clock for each AHU, a controller for each Fan-Coil Unit (FCU) and associated labor can be used to achieve the above recommendations. A cost of $\$ 3,900$ for the time clock and $\$ 1,392$ of fixed labor (based on previous experience) was assumed. A cost of $\$ 172$ for each controller, and $\$ 160$ of fixed labor was assumed for the FCUs. For two AHUs and eight FCUs, this is a total cost of $\$ 13,240$.

- Lighting Controls. Energy audits of this facility indicated a large number of open areas that had potential for savings via occupancy sensors. A cost of $\$ 0.95 / \mathrm{ft}^{2}$ was used based on Zhang et al. (2013). With a facility area of $18,170 \mathrm{ft}^{2}$, the estimated cost is $\$ 25,892$. The model was then run in each of the different climate zones using eQUEST. The results are listed in Tables 44-58 and shown in Figures 26-35. 
Table 44. Bldg. 463, savings and payback summary, Climate Zone 1A (Miami, FL).

\begin{tabular}{|l|c|c|c|l|c|}
\hline EEM & $\begin{array}{c}\text { Electrical } \\
\text { Savings } \\
(\mathrm{kWh} / \mathrm{yr})\end{array}$ & $\begin{array}{c}\text { Thermal } \\
\text { Savings } \\
\mathbf{( M i l .} \\
\text { Btu/yr) }\end{array}$ & $\begin{array}{c}\text { Annual Cost } \\
\text { Savings }\end{array}$ & $\begin{array}{c}\text { Implementation } \\
\text { Costs }\end{array}$ & $\begin{array}{c}\text { Payback } \\
\text { Period (yrs) }\end{array}$ \\
\hline Reduce Infiltration & 139,883 & 181 & $\$ 14,546$ & $\$ 24,567.58$ & 1.7 \\
\hline Lighting Controls & 14,946 & 0 & $\$ 1,403$ & $\$ 25,892$ & 18.4 \\
\hline Roof/Attic Insulation & 3,048 & 12 & $\$ 380$ & $\$ 16,216.49$ & 42.7 \\
\hline Replacement of Mechanical Equipment & 0 & 98 & $\$ 762$ & $\$ 25,125$ & 33.0 \\
\hline Replace Mechanical Equipment Controls & 564,067 & 544 & $\$ 57,198$ & $\$ 13,240$ & 0.2 \\
\hline Total & 721944 & 835 & $\$ 74,289$ & $\$ 105,041.32$ & 1.4 \\
\hline
\end{tabular}

Table 45. Bldg. 463, savings and payback summary, Climate Zone 2A (Houston, TX).

\begin{tabular}{|l|c|c|c|c|c|}
\hline EEM & $\begin{array}{c}\text { Electrical } \\
\text { Savings } \\
(\mathrm{kWh} / \mathrm{yr})\end{array}$ & $\begin{array}{c}\text { Thermal } \\
\text { Savings } \\
\text { (Mil. } \\
\text { Btu/yr) }\end{array}$ & $\begin{array}{c}\text { Annual Cost } \\
\text { Savings }\end{array}$ & $\begin{array}{c}\text { Implementation } \\
\text { Costs }\end{array}$ & $\begin{array}{c}\text { Payback } \\
\text { Period (yrs) }\end{array}$ \\
\hline Reduce Infiltration & 356,316 & 943 & $\$ 40,795$ & $\$ 24,568$ & 0.6 \\
\hline Lighting Controls & 14,946 & 0 & $\$ 1,403$ & $\$ 25,892$ & 18.4 \\
\hline Roof/Attic Insulation & 1,698 & 5 & $\$ 198$ & $\$ 16,216$ & 81.8 \\
\hline Replacement of Mechanical Equipment & 0 & 498 & $\$ 3,874$ & $\$ 25,125$ & 6.5 \\
\hline Replace Mechanical Equipment Controls & 816,159 & 2,200 & $\$ 93,753$ & $\$ 13,240$ & 0.1 \\
\hline Total & $1,189,119$ & 3,646 & $\$ 140,024$ & 105041 & 0.8 \\
\hline
\end{tabular}

Table 46. Bldg. 463, savings and payback summary, Climate Zone 2B (Phoenix, AZ).

\begin{tabular}{|l|c|c|c|c|c|}
\hline EEM & $\begin{array}{c}\text { Electrical } \\
\text { Savings } \\
(\mathrm{kWh} / \mathrm{yr})\end{array}$ & $\begin{array}{c}\text { Thermal } \\
\text { Savings } \\
\text { (Mil. } \\
\text { Btu/yr) }\end{array}$ & $\begin{array}{c}\text { Annual Cost } \\
\text { Savings }\end{array}$ & $\begin{array}{c}\text { Implementation } \\
\text { Costs }\end{array}$ & $\begin{array}{c}\text { Payback } \\
\text { Period (yrs) }\end{array}$ \\
\hline Reduce Infiltration & 208,197 & 523 & $\$ 23,619$ & $\$ 24,568$ & 1.0 \\
\hline Lighting Controls & 14,946 & 0 & $\$ 1,403$ & $\$ 25,892$ & 18.4 \\
\hline Roof/Attic Insulation & 4,541 & 12 & $\$ 520$ & $\$ 16,216$ & 31.2 \\
\hline Replacement of Mechanical Equipment & 0 & 277 & $\$ 2,155$ & $\$ 25,125$ & 11.7 \\
\hline Replace Mechanical Equipment Controls & 445,710 & 1,248 & $\$ 51,562$ & $\$ 13,240$ & 0.3 \\
\hline Total & 673,394 & 2,060 & $\$ 79,258$ & 105041 & 1.3 \\
\hline
\end{tabular}

Table 47. Bldg. 463, savings and payback summary, Climate Zone $3 \mathrm{~A}$ (Memphis, TN).

\begin{tabular}{|l|r|r|r|r|c|}
\hline & $\begin{array}{c}\text { Electrical } \\
\text { Savings } \\
(\mathrm{kWh} / \mathrm{yr})\end{array}$ & $\begin{array}{c}\text { Thermal } \\
\text { Savings } \\
\text { (Mil. } \\
\text { Btu/yr) }\end{array}$ & $\begin{array}{c}\text { Annual Cost } \\
\text { Savings }\end{array}$ & $\begin{array}{c}\text { Implementation } \\
\text { Costs }\end{array}$ & $\begin{array}{c}\text { Payback } \\
\text { Period (yrs) }\end{array}$ \\
\hline Reduce Infiltration & 347,496 & 1,181 & $\$ 41,818$ & $\$ 24,568$ & 0.6 \\
\hline Lighting Controls & 14,946 & 0 & $\$ 1,403$ & $\$ 25,892$ & 18.4 \\
\hline Roof/Attic Insulation & 1,465 & 8 & $\$ 200$ & $\$ 16,216$ & 81.2 \\
\hline Replacement of Mechanical Equipment & 0 & 705 & $\$ 5,485$ & $\$ 25,125$ & 4.6 \\
\hline Replace Mechanical Equipment Controls & 790,494 & 2,684 & $\$ 95,109$ & $\$ 13,240$ & 0.1 \\
\hline Total & $1,154,401$ & $\mathbf{4 , 5 7 8}$ & $\$ 144,015$ & 105041 & 0.7 \\
\hline
\end{tabular}


Table 48. Bldg. 463, savings and payback summary, Climate Zone 3B (El Paso, TX).

\begin{tabular}{|l|c|c|c|c|c|}
\hline EEM & $\begin{array}{c}\text { Electrical } \\
\text { Savings } \\
(\mathrm{kWh} / \mathrm{yr})\end{array}$ & $\begin{array}{c}\text { Thermal } \\
\text { Savings } \\
\text { (Mil. } \\
\text { Btu/yr) }\end{array}$ & $\begin{array}{c}\text { Annual Cost } \\
\text { Savings }\end{array}$ & $\begin{array}{c}\text { Implementation } \\
\text { Costs }\end{array}$ & $\begin{array}{c}\text { Payback } \\
\text { Period (yrs) }\end{array}$ \\
\hline Reduce Infiltration & 165,083 & 618 & $\$ 20,309$ & $\$ 24,568$ & 1.2 \\
\hline Lighting Controls & 14,946 & 0 & $\$ 1,403$ & $\$ 25,892$ & 18.4 \\
\hline Roof/Attic Insulation & 2,782 & 12 & $\$ 355$ & $\$ 16,216$ & 45.7 \\
\hline Replacement of Mechanical Equipment & 0 & 476 & $\$ 3,703$ & $\$ 25,125$ & 6.8 \\
\hline Replace Mechanical Equipment Controls & 576,371 & 1,926 & $\$ 69,106$ & $\$ 13,240$ & 0.2 \\
\hline Total & 759,182 & 3,032 & $\$ 94,876$ & 105041 & 1.1 \\
\hline
\end{tabular}

Table 49. Bldg. 463, savings and payback summary, Climate Zone 3C (San Francisco, CA).

\begin{tabular}{|l|c|c|c|c|c|}
\hline EEM & $\begin{array}{c}\text { Electrical } \\
\text { Savings } \\
(\mathrm{kWh} / \mathrm{yr})\end{array}$ & $\begin{array}{c}\text { Thermal } \\
\text { Savings } \\
\text { (Mil. } \\
\text { Btu/yr) }\end{array}$ & $\begin{array}{c}\text { Annual Cost } \\
\text { Savings }\end{array}$ & $\begin{array}{c}\text { Implementation } \\
\text { Costs }\end{array}$ & $\begin{array}{c}\text { Payback } \\
\text { Period (yrs) }\end{array}$ \\
\hline Reduce Infiltration & 175,894 & 878 & $\$ 23,347$ & $\$ 24,568$ & 1.1 \\
\hline Lighting Controls & 14,946 & 0 & $\$ 1,403$ & $\$ 25,892$ & 18.4 \\
\hline Roof/Attic Insulation & 899 & 13 & $\$ 186$ & $\$ 16,216$ & 87.4 \\
\hline Replacement of Mechanical Equipment & 0 & 549 & $\$ 4,271$ & $\$ 25,125$ & 5.9 \\
\hline Replace Mechanical Equipment Controls & 474,231 & 2,215 & $\$ 61,763$ & $\$ 13,240$ & 0.2 \\
\hline Total & 665,970 & 3,655 & $\$ 90,970$ & 105041 & 1.2 \\
\hline
\end{tabular}

Table 50. Bldg. 463, savings and payback summary, Climate Zone 4A (Baltimore, MD).

\begin{tabular}{|l|r|r|r|c|c|}
\hline EEM & $\begin{array}{c}\text { Electrical } \\
\text { Savings } \\
(\mathrm{kWh} / \mathrm{yr})\end{array}$ & $\begin{array}{c}\text { Thermal } \\
\text { Savings } \\
\text { (Mil. } \\
\text { Btu/yr) }\end{array}$ & $\begin{array}{c}\text { Annual Cost } \\
\text { Savings }\end{array}$ & $\begin{array}{c}\text { Implementation } \\
\text { Costs }\end{array}$ & $\begin{array}{c}\text { Payback } \\
\text { Period (yrs) }\end{array}$ \\
\hline Reduce Infiltration & 360,217 & 1,379 & $\$ 44,553$ & $\$ 24,568$ & 0.6 \\
\hline Lighting Controls & 14,946 & 0 & $\$ 1,403$ & $\$ 25,892$ & 18.4 \\
\hline Roof/Attic Insulation & 1,005 & 11 & $\$ 180$ & $\$ 16,216$ & 90.1 \\
\hline Replacement of Mechanical Equipment & 0 & 927 & $\$ 7,212$ & $\$ 25,125$ & 3.5 \\
\hline Replace Mechanical Equipment Controls & 783,356 & 3,067 & $\$ 97,418$ & $\$ 13,240$ & 0.1 \\
\hline Total & $1,159,524$ & 5,384 & $\$ 150,767$ & 105041 & 0.7 \\
\hline
\end{tabular}

Table 51. Bldg. 463, savings and payback summary, Climate Zone 4B (Albuquerque, NM).

\begin{tabular}{|l|r|r|r|r|c|}
\hline & $\begin{array}{c}\text { Electrical } \\
\text { Savings } \\
(\mathrm{kWh} / \mathrm{yr})\end{array}$ & $\begin{array}{c}\text { Thermal } \\
\text { Savings } \\
\text { (Mil. } \\
\text { Btu/yr) }\end{array}$ & $\begin{array}{c}\text { Annual Cost } \\
\text { Savings }\end{array}$ & $\begin{array}{c}\text { Implementation } \\
\text { Costs }\end{array}$ & $\begin{array}{c}\text { Payback } \\
\text { Period (yrs) }\end{array}$ \\
\hline Reduce Infiltration & 286,390 & 1,139 & $\$ 35,753$ & $\$ 24,568$ & 0.7 \\
\hline Lighting Controls & 14,946 & 0 & $\$ 1,403$ & $\$ 25,892$ & 18.4 \\
\hline Roof/Attic Insulation & 1,808 & 11 & $\$ 255$ & $\$ 16,216$ & 63.5 \\
\hline Replacement of Mechanical Equipment & 0 & 705 & $\$ 5,485$ & $\$ 25,125$ & 4.6 \\
\hline Replace Mechanical Equipment Controls & 623,043 & 2,401 & $\$ 77,184$ & $\$ 13,240$ & 0.2 \\
\hline Total & $\mathbf{9 2 6 , 1 8 7}$ & $\mathbf{4 , 2 5 6}$ & $\$ 120,081$ & 105041 & 0.9 \\
\hline
\end{tabular}


Table 52. Bldg. 463, savings and payback summary, Climate Zone 4C (Seattle, WA).

\begin{tabular}{|l|r|r|r|r|c|}
\hline EEM & $\begin{array}{c}\text { Electrical } \\
\text { Savings } \\
(\mathrm{kWh} / \mathrm{yr})\end{array}$ & $\begin{array}{c}\text { Thermal } \\
\text { Savings } \\
\text { (Mil. } \\
\text { Btu/yr) }\end{array}$ & $\begin{array}{c}\text { Annual Cost } \\
\text { Savings }\end{array}$ & $\begin{array}{c}\text { Implementation } \\
\text { Costs }\end{array}$ & $\begin{array}{c}\text { Payback } \\
\text { Period (yrs) }\end{array}$ \\
\hline Reduce Infiltration & 226,708 & 1,122 & $\$ 30,017$ & $\$ 24,568$ & 0.8 \\
\hline Lighting Controls & 14,946 & 0 & $\$ 1,403$ & $\$ 25,892$ & 18.4 \\
\hline Roof/Attic Insulation & 818 & 14 & $\$ 186$ & $\$ 16,216$ & 87.3 \\
\hline Replacement of Mechanical Equipment & 0 & 771 & $\$ 5,998$ & $\$ 25,125$ & 4.2 \\
\hline Replace Mechanical Equipment Controls & 516,729 & 2,542 & $\$ 68,298$ & $\$ 13,240$ & 0.2 \\
\hline Total & 759,201 & $\mathbf{4 , 4 4 9}$ & $\$ 105,902$ & 105041 & 1.0 \\
\hline
\end{tabular}

Table 53. Bldg. 463, savings and payback summary, Climate Zone 5A (Chicago, IL).

\begin{tabular}{|l|r|r|r|c|c|}
\hline EEM & $\begin{array}{c}\text { Electrical } \\
\text { Savings } \\
(\mathrm{kWh} / \mathrm{yr})\end{array}$ & $\begin{array}{c}\text { Thermal } \\
\text { Savings } \\
\text { (Mil. } \\
\text { Btu/yr) }\end{array}$ & $\begin{array}{c}\text { Annual Cost } \\
\text { Savings }\end{array}$ & $\begin{array}{c}\text { Implementation } \\
\text { Costs }\end{array}$ & $\begin{array}{c}\text { Payback } \\
\text { Period (yrs) }\end{array}$ \\
\hline Reduce Infiltration & 521,576 & 2,054 & $\$ 64,956$ & $\$ 24,568$ & 0.4 \\
\hline Lighting Controls & 14,946 & 0 & $\$ 1,403$ & $\$ 25,892$ & 18.4 \\
\hline Roof/Attic Insulation & 789 & 13 & $\$ 175$ & $\$ 16,216$ & 92.5 \\
\hline Replacement of Mechanical Equipment & 0 & 1,316 & $\$ 10,238$ & $\$ 25,125$ & 2.5 \\
\hline Replace Mechanical Equipment Controls & 991,412 & 4,142 & $\$ 125,318$ & $\$ 13,240$ & 0.1 \\
\hline Total & $1,528,723$ & 7,525 & $\$ 202,092$ & 105041 & 0.5 \\
\hline
\end{tabular}

Table 54. Bldg. 463, savings and payback summary, Climate Zone 5B (Colorado Springs, CO).

\begin{tabular}{|l|r|r|r|c|c|}
\hline EEM & $\begin{array}{c}\text { Electrical } \\
\text { Savings } \\
(\mathrm{kWh} / \mathrm{yr})\end{array}$ & $\begin{array}{c}\text { Thermal } \\
\text { Savings } \\
\text { (Mil. } \\
\text { Btu/yr) }\end{array}$ & $\begin{array}{c}\text { Annual Cost } \\
\text { Savings }\end{array}$ & $\begin{array}{c}\text { Implementation } \\
\text { Costs }\end{array}$ & $\begin{array}{c}\text { Payback } \\
\text { Period (yrs) }\end{array}$ \\
\hline Reduce Infiltration & 393,220 & 1,600 & $\$ 49,371$ & $\$ 24,568$ & 0.5 \\
\hline Lighting Controls & 14,946 & 0 & $\$ 1,403$ & $\$ 25,892$ & 18.4 \\
\hline Roof/Attic Insulation & 986 & 16 & $\$ 217$ & $\$ 16,216$ & 74.7 \\
\hline Replacement of Mechanical Equipment & 0 & 1,138 & $\$ 8,854$ & $\$ 25,125$ & 2.8 \\
\hline Replace Mechanical Equipment Controls & 918,404 & 3,772 & $\$ 115,584$ & $\$ 13,240$ & 0.1 \\
\hline Total & $1,327,556$ & 6,526 & $\$ 175,430$ & 105041 & 0.6 \\
\hline
\end{tabular}

Table 55. Bldg. 463, savings and payback summary, Climate Zone 6A (Burlington, VT).

\begin{tabular}{|l|r|r|r|r|c|}
\hline & $\begin{array}{c}\text { Electrical } \\
\text { Savings } \\
(\mathrm{kWh} / \mathrm{yr})\end{array}$ & $\begin{array}{c}\text { Thermal } \\
\text { Savings } \\
\text { (Mil. } \\
\text { Btu/yr) }\end{array}$ & $\begin{array}{c}\text { Annual Cost } \\
\text { Savings }\end{array}$ & $\begin{array}{c}\text { Implementation } \\
\text { Costs }\end{array}$ & $\begin{array}{c}\text { Payback } \\
\text { Period (yrs) }\end{array}$ \\
\hline Reduce Infiltration & 530,760 & 2,189 & $\$ 66,869$ & $\$ 24,568$ & 0.4 \\
\hline Lighting Controls & 14,946 & 0 & $\$ 1,403$ & $\$ 25,892$ & 18.4 \\
\hline Roof/Attic Insulation & 598 & 17 & $\$ 188$ & $\$ 16,216$ & 86.1 \\
\hline Replacement of Mechanical Equipment & 0 & 1,402 & $\$ 10,908$ & $\$ 25,125$ & 2.3 \\
\hline Replace Mechanical Equipment Controls & 974,154 & 4,049 & $\$ 122,974$ & $\$ 13,240$ & 0.1 \\
\hline Total & $1,520,458$ & 7,657 & $\$ 202,342$ & 105041 & 0.5 \\
\hline
\end{tabular}


Table 56. Bldg. 463, savings and payback summary, Climate Zone 6B (Helena, MT).

\begin{tabular}{|l|r|r|r|r|c|}
\hline EEM & $\begin{array}{c}\text { Electrical } \\
\text { Savings } \\
(\mathrm{kWh} / \mathrm{yr})\end{array}$ & $\begin{array}{c}\text { Thermal } \\
\text { Savings } \\
\text { (Mil. } \\
\text { Btu/yr) }\end{array}$ & $\begin{array}{c}\text { Annual Cost } \\
\text { Savings }\end{array}$ & $\begin{array}{c}\text { Implementation } \\
\text { Costs }\end{array}$ & $\begin{array}{c}\text { Payback } \\
\text { Period (yrs) }\end{array}$ \\
\hline Reduce Infiltration & 514,332 & 2,122 & $\$ 64,805$ & $\$ 24,568$ & 0.4 \\
\hline Lighting Controls & 14,946 & 0 & $\$ 1,403$ & $\$ 25,892$ & 18.4 \\
\hline Roof/Attic Insulation & 1,297 & 33 & $\$ 379$ & $\$ 16,216$ & 42.8 \\
\hline Replacement of Mechanical Equipment & 0 & 1,371 & $\$ 10,666$ & $\$ 25,125$ & 2.4 \\
\hline Replace Mechanical Equipment Controls & 945,457 & 4,090 & $\$ 120,599$ & $\$ 13,240$ & 0.1 \\
\hline Total & $1,476,032$ & 7,616 & $\$ 197,852$ & 105041 & 0.5 \\
\hline
\end{tabular}

Table 57. Bldg. 463, savings and payback summary, Climate Zone 7A (Duluth, MN).

\begin{tabular}{|l|r|r|r|c|c|}
\hline EEM & $\begin{array}{c}\text { Electrical } \\
\text { Savings } \\
(\mathrm{kWh} / \mathrm{yr})\end{array}$ & $\begin{array}{c}\text { Thermal } \\
\text { Savings } \\
\text { (Mil. } \\
\text { Btu/yr) }\end{array}$ & $\begin{array}{c}\text { Annual Cost } \\
\text { Savings }\end{array}$ & $\begin{array}{c}\text { Implementation } \\
\text { Costs }\end{array}$ & $\begin{array}{c}\text { Payback } \\
\text { Period (yrs) }\end{array}$ \\
\hline Reduce Infiltration & 647,976 & 2,618 & $\$ 81,213$ & $\$ 24,568$ & 0.3 \\
\hline Lighting Controls & 14,946 & 0 & $\$ 1,403$ & $\$ 25,892$ & 18.4 \\
\hline Roof/Attic Insulation & 484 & 17 & $\$ 178$ & $\$ 16,216$ & 91.3 \\
\hline Replacement of Mechanical Equipment & 0 & 1,753 & $\$ 13,638$ & $\$ 25,125$ & 1.8 \\
\hline Replace Mechanical Equipment Controls & $1,129,468$ & 4,794 & $\$ 143,354$ & $\$ 13,240$ & 0.1 \\
\hline Total & $1,792,874$ & 9,182 & $\$ 239,787$ & 105041 & 0.4 \\
\hline
\end{tabular}

Table 58. Bldg. 463, savings and payback summary, Climate Zone 8A (Fairbanks, AK).

\begin{tabular}{|l|r|r|r|r|c|}
\hline EEM & $\begin{array}{c}\text { Electrical } \\
\text { Savings } \\
(\mathrm{kWh} / \mathrm{yr})\end{array}$ & $\begin{array}{c}\text { Thermal } \\
\text { Savings } \\
\text { (Mil. } \\
\text { Btu/yr) }\end{array}$ & $\begin{array}{c}\text { Annual Cost } \\
\text { Savings }\end{array}$ & $\begin{array}{c}\text { Implementation } \\
\text { Costs }\end{array}$ & $\begin{array}{c}\text { Payback } \\
\text { Period (yrs) }\end{array}$ \\
\hline Reduce Infiltration & 810,770 & 3,561 & $\$ 103,836$ & $\$ 24,568$ & 0.2 \\
\hline Lighting Controls & 14,946 & 0 & $\$ 1,403$ & $\$ 25,892$ & 18.4 \\
\hline Roof/Attic Insulation & -368 & 56 & $\$ 401$ & $\$ 16,216$ & 40.4 \\
\hline Replacement of Mechanical Equipment & 0 & 2,205 & $\$ 17,155$ & $\$ 25,125$ & 1.5 \\
\hline Replace Mechanical Equipment Controls & $1,284,219$ & 5,314 & $\$ 161,931$ & $\$ 13,240$ & 0.1 \\
\hline Total & $2,109,567$ & 11,136 & $\$ 284,726$ & 105041 & 0.4 \\
\hline
\end{tabular}


Figure 26. Bldg. 463 , annual cost savings resulting from EEM “Reduce Infiltration," by climate zone.

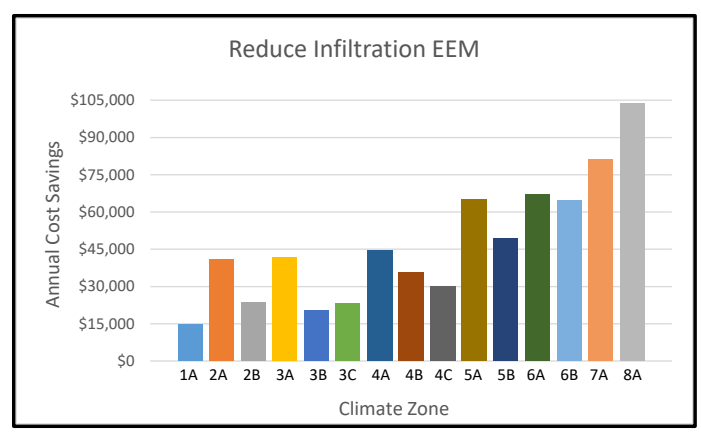

Figure 28. Bldg. 463, annual cost savings resulting from EEM “Lighting Controls," by climate zone.

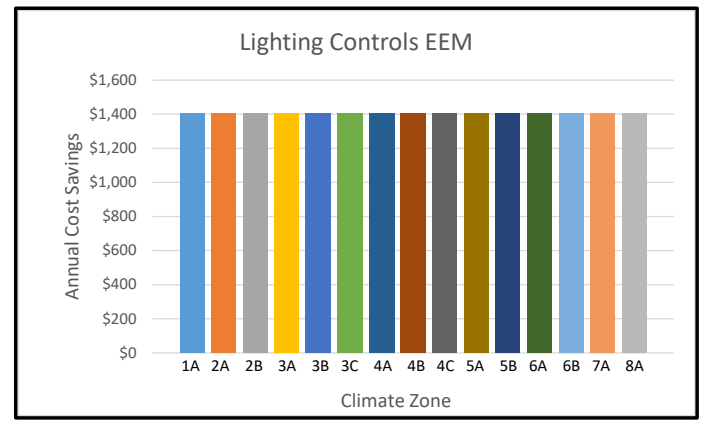

Figure 30. Bldg. 463, annual cost savings resulting from EEM “Roof/Attic Insulation," by climate zone.

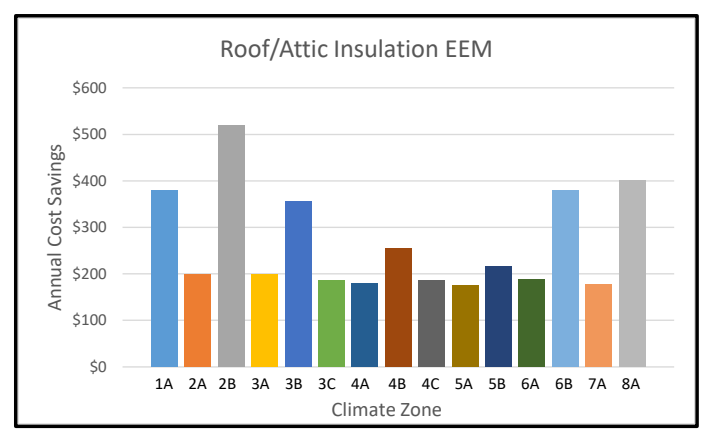

Figure 27. BIdg. 463, simple payback resulting from EEM “Reduce Infiltration," by climate zone.

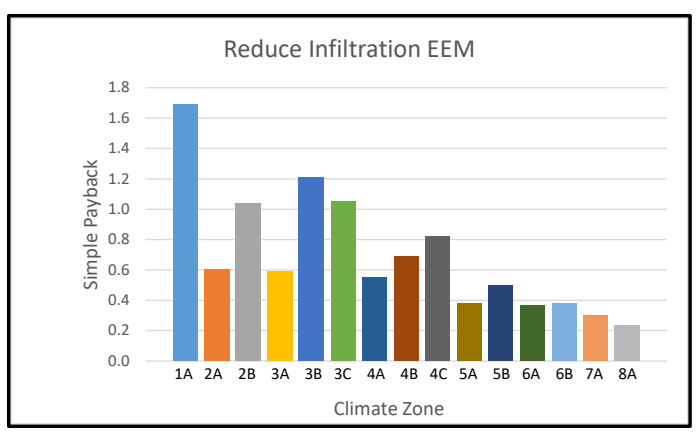

Figure 29. Bldg. 463, simple payback resulting from EEM “Lighting Controls," by climate zone.

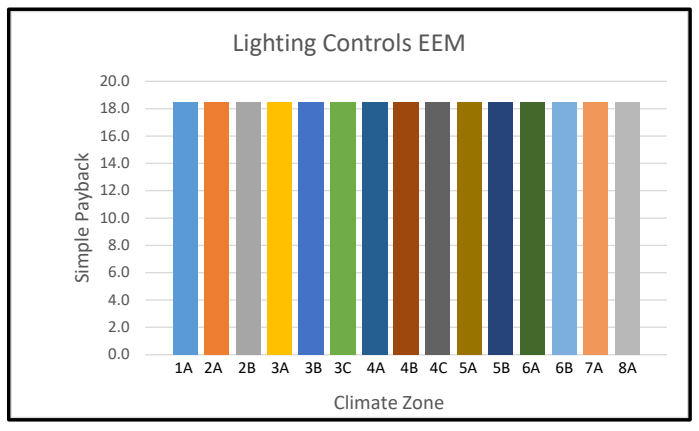

Figure 31. BIdg. 463, simple payback resulting from EEM “Roof/Attic Insulation," by climate zone.

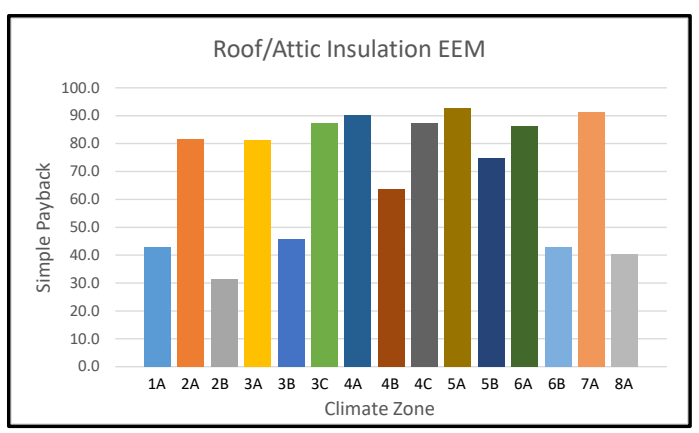


Figure 32. BIdg. 463, annual cost savings resulting from EEM “Replace Mechanical Equipment EEM," by climate zone.

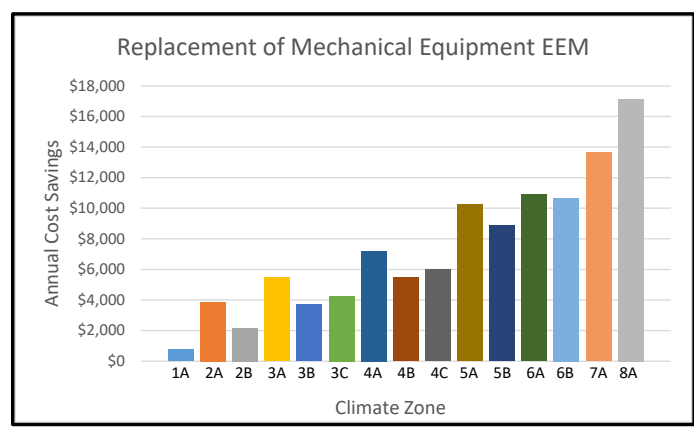

Figure 34. Bldg. 463, annual cost savings resulting from EEM “Replace Mechanical Equipment Controls EEM," by climate zone.

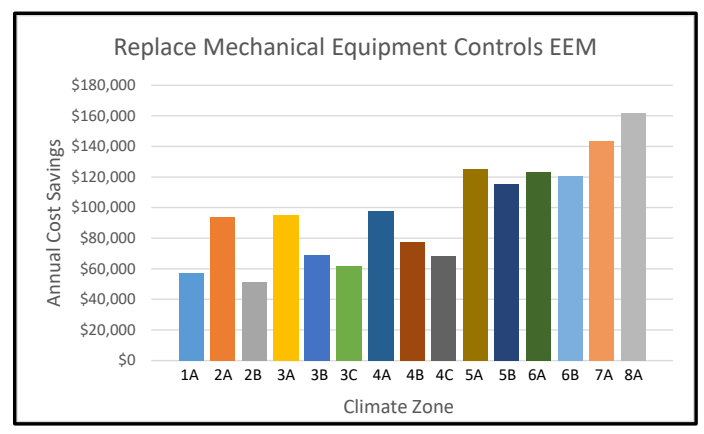

Figure 33. BIdg. 463, simple payback resulting from EEM “Replace Mechanical Equipment EEM," by climate zone.

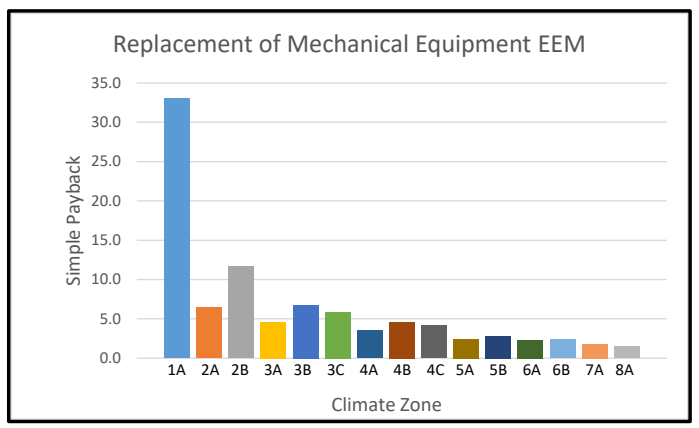

Figure 35. Bldg. 463, simple payback resulting from EEM “Replace Mechanical Equipment Controls EEM," by climate zone.

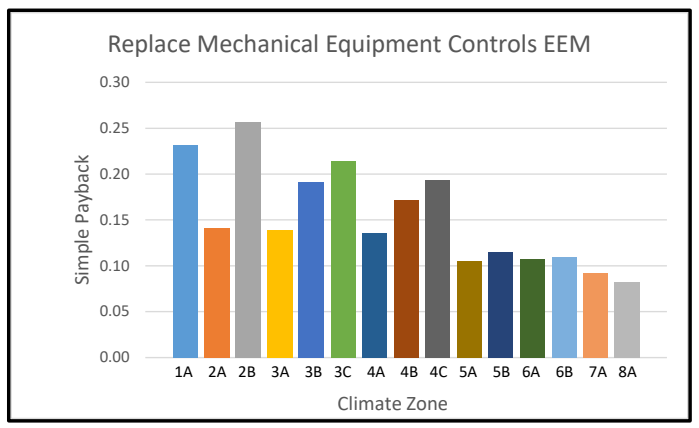

\subsubsection{Bldg. 750 EEM savings by climate zone}

The EEMs chosen for Bldg. 750 were:

- Reduce Infiltration. Infiltration of the building was changed from 2.00 ACH to 1.00 ACH. The implementation cost was calculated from 270 windows that are $4 \times 6.3 \mathrm{ft}$, and seven doors that are $3 \times 7 \mathrm{ft}$ for a total of $5653 \mathrm{ft}$ of weatherstripping, at a cost of $\$ 4.41 / \mathrm{ft}$.

- Roof/Attic Insulation. Add R-38 batt insulation to the roof, where previously there was no insulation. The cost of the insulation was found to be $\$ 1.93 / \mathrm{ft}^{2}$ in 2014 , to which an escalation of $3 \%$ per year was added. With 9,085 $\mathrm{ft}^{2}$ of roof/attic area, the estimated cost is $\$ 16,216$.

- Replacement of Mechanical Equipment. Replace the building's chiller, which has a coefficient of performance (COP) of 2.7, with a high efficiency chiller with a COP of 7 . This replacement costs, on average, about $\$ 1,260 /$ ton and varies by climate zone because the size of the chiller required. Size was estimated from the peak cooling load estimated by eQUEST. 
- Replace Mechanical Equipment Controls. Changed the building from an occupancy of $24 \mathrm{hrs}$ per day every day of the week to an occupancy of 0700-1700 M-F, and unoccupied Sa-Su and on Holidays. It also changed the temperature setpoints from occupied and unoccupied cooling and heating of 72 and $68^{\circ} \mathrm{F}$, to occupied cooling and heating of 78 and $68{ }^{\circ} \mathrm{F}$ and unoccupied cooling and heating of 85 and $55^{\circ} \mathrm{F}$, respectively. The HVAC system fans were set to operate 2 hours before open and 2 hours after close of the building. The fans were set to cycle at night with minimum Outside Air, to use an economizer, to cycle on via control zones, and to have the capability to operate in a continuous ON mode. A time clock for each AHU, a controller for each FCU and associated labor can be used to achieve the above recommendations. A cost of $\$ 3,900$ for the time clock and $\$ 1,392$ of fixed labor (based on previous experience) was assumed. A cost of $\$ 172$ for each controller, and $\$ 160$ of fixed labor was assumed for the FCUs. For four AHUs and 20 FCUs, this is a total cost of $\$ 27,808$.

- Lighting Controls. Energy audits of this facility indicated a large number of open areas that had potential for savings via occupancy sensors. A cost of $\$ 0.95 / \mathrm{ft}^{2}$ was used based on Zhang et al. (2013). With a facility area of $38,480 \mathrm{ft}^{2}$, the estimated cost is $\$ 36,556$.

The model was then run in each of the different climate zones using eQUEST. The results are listed in Tables 59-73 and shown in Figures 36-45.

Table 59. Bldg. 750, savings and payback summary, Climate Zone 1A (Miami, FL).

\begin{tabular}{|l|c|c|c|c|c|}
\hline EEM & $\begin{array}{c}\text { Electrical } \\
\text { Savings } \\
(\mathbf{k W h} / \mathbf{y r})\end{array}$ & $\begin{array}{c}\text { Thermal } \\
\text { Savings } \\
\text { (Mil. Btu/yr) }\end{array}$ & $\begin{array}{c}\text { Annual Cost } \\
\text { Savings }\end{array}$ & $\begin{array}{c}\text { Implementation } \\
\text { Costs }\end{array}$ & $\begin{array}{c}\text { Payback } \\
\text { Period (yrs) }\end{array}$ \\
\hline Reduce Infiltration & 57,905 & 8 & $\$ 5,500$ & $\$ 24,929.73$ & 4.5 \\
\hline Lighting Controls & 39,585 & & $\$ 3,717$ & $\$ 36,556$ & 9.8 \\
\hline Roof/Attic Insulation & 896 & 1 & $\$ 92$ & $\$ 19,164.95$ & 208.5 \\
\hline Replacement of Chiller & 515,000 & 0 & $\$ 48,359$ & $\$ 189,000$ & 3.9 \\
\hline Replace Mechanical Equipment Controls & 878,023 & 7 & $\$ 82,501$ & $\$ 27,808$ & 0.3 \\
\hline Total & $1,491,409$ & 16 & $\$ 140,168$ & $\$ 297,458.68$ & 2.1 \\
\hline
\end{tabular}


Table 60. Bldg. 750, savings and payback summary, Climate Zone 2A (Houston, TX).

\begin{tabular}{|l|c|c|c|c|c|}
\hline EEM & $\begin{array}{c}\text { Electrical } \\
\text { Savings } \\
(\mathrm{kWh} / \mathrm{yr})\end{array}$ & $\begin{array}{c}\text { Thermal } \\
\text { Savings } \\
(\text { Mil. Btu/yr) }\end{array}$ & $\begin{array}{c}\text { Annual Cost } \\
\text { Savings }\end{array}$ & $\begin{array}{c}\text { Implementation } \\
\text { Costs }\end{array}$ & $\begin{array}{c}\text { Payback } \\
\text { Period (yrs) }\end{array}$ \\
\hline Reduce Infiltration & 32,194 & 171 & $\$ 4,353$ & $\$ 24,930$ & 5.7 \\
\hline Lighting Controls & 39,585 & & $\$ 3,717$ & $\$ 36,556$ & 9.8 \\
\hline Roof/Attic Insulation & 646 & 7 & $\$ 115$ & $\$ 19,165$ & 166.5 \\
\hline Replacement of Chiller & 399,000 & 0 & $\$ 37,466$ & $\$ 189,000$ & 5.0 \\
\hline Replace Mechanical Equipment Controls & 766,299 & 148 & $\$ 73,107$ & $\$ 27,808$ & 0.4 \\
\hline Total & $\mathbf{1 , 2 3 7 , 7 2 4}$ & $\mathbf{3 2 6}$ & $\mathbf{\$ 1 1 8 , 7 5 9}$ & $\mathbf{2 9 7 , 4 5 9}$ & $\mathbf{2 . 5}$ \\
\hline
\end{tabular}

Table 61. Bldg. 750, savings and payback summary, Climate Zone 2B (Phoenix, AZ).

\begin{tabular}{|l|c|c|c|c|c|}
\hline EEM & $\begin{array}{c}\text { Electrical } \\
\text { Savings } \\
(\mathrm{kWh} / \mathrm{yr})\end{array}$ & $\begin{array}{c}\text { Thermal } \\
\text { Savings } \\
(\text { Mil. Btu/yr) }\end{array}$ & $\begin{array}{c}\text { Annual Cost } \\
\text { Savings }\end{array}$ & $\begin{array}{c}\text { Implementation } \\
\text { Costs }\end{array}$ & $\begin{array}{c}\text { Payback } \\
\text { Period (yrs) }\end{array}$ \\
\hline Reduce Infiltration & 21,218 & 115 & $\$ 2,887$ & $\$ 24,930$ & 8.6 \\
\hline Lighting Controls & 39,585 & & $\$ 3,717$ & $\$ 36,556$ & 9.8 \\
\hline Roof/Attic Insulation & 824 & 7 & $\$ 132$ & $\$ 19,165$ & 145.4 \\
\hline Replacement of Chiller & 424,000 & 0 & $\$ 39,814$ & $\$ 189,000$ & 4.7 \\
\hline Replace Mechanical Equipment Controls & 754,321 & 89 & $\$ 71,523$ & $\$ 27,808$ & 0.4 \\
\hline Total & $1,239,948$ & $\mathbf{2 1 1}$ & $\mathbf{\$ 1 1 8 , 0 7 3}$ & $\mathbf{2 9 7 , 4 5 9}$ & $\mathbf{2 . 5}$ \\
\hline
\end{tabular}

Table 62. Bldg. 750, savings and payback summary, Climate Zone 3A (Memphis, TN).

\begin{tabular}{|l|c|c|c|c|c|}
\hline EEM & $\begin{array}{c}\text { Electrical } \\
\text { Savings } \\
(\mathrm{kWh} / \mathrm{yr})\end{array}$ & $\begin{array}{c}\text { Thermal } \\
\text { Savings } \\
(\text { Mil. Btu/yr) }\end{array}$ & $\begin{array}{c}\text { Annual Cost } \\
\text { Savings }\end{array}$ & $\begin{array}{c}\text { Implementation } \\
\text { Costs }\end{array}$ & $\begin{array}{c}\text { Payback Period } \\
\text { (yrs) }\end{array}$ \\
\hline Reduce Infiltration & 28,847 & 335 & $\$ 5,315$ & $\$ 24,930$ & 4.7 \\
\hline Lighting Controls & 39,585 & & $\$ 3,717$ & $\$ 36,556$ & 9.8 \\
\hline Roof/Attic Insulation & 556 & 12 & $\$ 146$ & $\$ 19,165$ & 131.7 \\
\hline Replacement of Chiller & 327,000 & 0 & $\$ 30,705$ & $\$ 163,800$ & 5.3 \\
\hline Replace Mechanical Equipment Controls & 701,499 & 355 & $\$ 68,633$ & $\$ 27,808$ & 0.4 \\
\hline Total & $1,097,487$ & 702 & $\$ 108,516$ & 272,259 & 2.5 \\
\hline
\end{tabular}

Table 63. Bldg. 750, savings and payback summary, Climate Zone 3B (El Paso, TX).

\begin{tabular}{|l|c|c|c|c|c|}
\hline EEM & $\begin{array}{c}\text { Electrical } \\
\text { Savings } \\
(\mathbf{k W h} / \mathrm{yr})\end{array}$ & $\begin{array}{c}\text { Thermal } \\
\text { Savings } \\
(\text { Mil. Btu/yr) }\end{array}$ & $\begin{array}{c}\text { Annual Cost } \\
\text { Savings }\end{array}$ & $\begin{array}{c}\text { Implementation } \\
\text { Costs }\end{array}$ & $\begin{array}{c}\text { Payback } \\
\text { Period (yrs) }\end{array}$ \\
\hline Reduce Infiltration & 16,687 & 224 & $\$ 3,310$ & $\$ 24,930$ & 7.5 \\
\hline Lighting Controls & 39,585 & & $\$ 3,717$ & $\$ 36,556$ & 9.8 \\
\hline Roof/Attic Insulation & 703 & 12 & $\$ 159$ & $\$ 19,165$ & 120.3 \\
\hline Replacement of Chiller & 312,000 & 0 & $\$ 29,297$ & $\$ 163,800$ & 5.6 \\
\hline Replace Mechanical Equipment Controls & 708,737 & 268 & $\$ 68,635$ & $\$ 27,808$ & 0.4 \\
\hline Total & $\mathbf{1 , 0 7 7 , 7 1 2}$ & $\mathbf{5 0 4}$ & $\mathbf{\$ 1 0 5 , 1 1 8}$ & $\mathbf{2 7 2 , 2 5 9}$ & $\mathbf{2 . 6}$ \\
\hline
\end{tabular}


Table 64. Bldg. 750, savings and payback summary, Climate Zone 3C (San Francisco, CA).

\begin{tabular}{|c|c|c|c|c|c|}
\hline EEM & $\begin{array}{c}\text { Electrical } \\
\text { Savings } \\
\text { (kWh/yr) }\end{array}$ & $\begin{array}{l}\text { Thermal } \\
\text { Savings } \\
\text { (Mil. Btu/yr) }\end{array}$ & $\begin{array}{c}\text { Annual Cost } \\
\text { Savings }\end{array}$ & $\begin{array}{l}\text { Implementation } \\
\text { Costs }\end{array}$ & $\begin{array}{c}\text { Payback } \\
\text { Period (yrs) }\end{array}$ \\
\hline Reduce Infiltration & 3,100 & 285 & $\$ 2,508$ & $\$ 24,930$ & 9.9 \\
\hline Lighting Controls & 39,585 & & $\$ 3,717$ & $\$ 36,556$ & 9.8 \\
\hline Roof/Attic Insulation & 122 & 14 & $\$ 120$ & $\$ 19,165$ & 159.2 \\
\hline Replacement of Chiller & 181,000 & 0 & $\$ 16,996$ & $\$ 163,800$ & 9.6 \\
\hline Replace Mechanical Equipment Controls & 581,913 & 204 & $\$ 56,229$ & $\$ 27,808$ & 0.5 \\
\hline Total & 805,720 & 503 & $\$ 79,570$ & 272,259 & 3.4 \\
\hline
\end{tabular}

Table 65. Bldg. 750, savings and payback summary, Climate Zone 4A (Baltimore, MD).

\begin{tabular}{|l|c|c|c|c|c|}
\hline EEM & $\begin{array}{c}\text { Electrical } \\
\text { Savings } \\
(\mathrm{kWh} / \mathrm{yr})\end{array}$ & $\begin{array}{c}\text { Thermal } \\
\text { Savings } \\
(\text { Mil. Btu/yr) }\end{array}$ & $\begin{array}{c}\text { Annual Cost } \\
\text { Savings }\end{array}$ & $\begin{array}{c}\text { Implementation } \\
\text { Costs }\end{array}$ & $\begin{array}{c}\text { Payback } \\
\text { Period (yrs) }\end{array}$ \\
\hline Reduce Infiltration & 16,066 & 539 & $\$ 5,702$ & $\$ 24,930$ & 4.4 \\
\hline Lighting Controls & 39,585 & & $\$ 3,717$ & $\$ 36,556$ & 9.8 \\
\hline Roof/Attic Insulation & 403 & 14 & $\$ 147$ & $\$ 19,165$ & 130.6 \\
\hline Replacement of Chiller & 247,000 & 0 & $\$ 23,193$ & $\$ 163,800$ & 7.1 \\
\hline Replace Mechanical Equipment Controls & 614,415 & 620 & $\$ 62,517$ & $\$ 27,808$ & 0.4 \\
\hline Total & $\mathbf{9 1 7 , 4 6 9}$ & $\mathbf{1 , 1 7 3}$ & $\mathbf{\$ 9 5 , 2 7 6}$ & $\mathbf{2 7 2 , 2 5 9}$ & $\mathbf{2 . 9}$ \\
\hline
\end{tabular}

Table 66. Bldg. 750, savings and payback summary, Climate Zone 4B (Albuquerque, NM).

\begin{tabular}{|l|c|c|c|c|c|}
\hline EEM & $\begin{array}{c}\text { Electrical } \\
\text { Savings } \\
(\mathrm{kWh} / \mathrm{yr})\end{array}$ & $\begin{array}{c}\text { Thermal } \\
\text { Savings } \\
(\text { Mil. Btu/yr) }\end{array}$ & $\begin{array}{c}\text { Annual Cost } \\
\text { Savings }\end{array}$ & $\begin{array}{c}\text { Implementation } \\
\text { Costs }\end{array}$ & $\begin{array}{c}\text { Payback } \\
\text { Period (yrs) }\end{array}$ \\
\hline Reduce Infiltration & 6,831 & 396 & $\$ 3,722$ & $\$ 24,930$ & 6.7 \\
\hline Lighting Controls & 39,585 & & $\$ 3,717$ & $\$ 36,556$ & 9.8 \\
\hline Roof/Attic Insulation & 646 & 15 & $\$ 177$ & $\$ 19,165$ & 108.1 \\
\hline Replacement of Chiller & 253,000 & 0 & $\$ 23,757$ & $\$ 126,000$ & 5.3 \\
\hline Replace Mechanical Equipment Controls & 639,793 & 470 & $\$ 63,733$ & $\$ 27,808$ & 0.4 \\
\hline Total & $\mathbf{9 3 9 , 8 5 5}$ & $\mathbf{8 8 1}$ & $\$ 95,107$ & $\mathbf{2 3 4 , 4 5 9}$ & $\mathbf{2 . 5}$ \\
\hline
\end{tabular}

Table 67. Bldg. 750, savings and payback summary, Climate Zone 4C (Seattle, WA).

\begin{tabular}{|l|c|c|c|c|c|}
\hline EEM & $\begin{array}{c}\text { Electrical } \\
\text { Savings } \\
(\mathrm{kWh} / \mathrm{yr})\end{array}$ & $\begin{array}{c}\text { Thermal } \\
\text { Savings } \\
(\text { Mil. Btu/yr) }\end{array}$ & $\begin{array}{c}\text { Annual Cost } \\
\text { Savings }\end{array}$ & $\begin{array}{c}\text { Implementation } \\
\text { Costs }\end{array}$ & $\begin{array}{c}\text { Payback } \\
\text { Period (yrs) }\end{array}$ \\
\hline Reduce Infiltration & $-14,330$ & 535 & $\$ 2,817$ & $\$ 24,930$ & 8.9 \\
\hline Lighting Controls & 39,585 & & $\$ 3,717$ & $\$ 36,556$ & 9.8 \\
\hline Roof/Attic Insulation & 243 & 17 & $\$ 155$ & $\$ 19,165$ & 123.6 \\
\hline Replacement of Chiller & 161,000 & 0 & $\$ 15,118$ & $\$ 126,000$ & 8.3 \\
\hline Replace Mechanical Equipment Controls & 548,648 & 514 & $\$ 55,517$ & $\$ 27,808$ & 0.5 \\
\hline Total & 735,146 & 1,066 & $\$ 77,324$ & 234,459 & 3.0 \\
\hline
\end{tabular}


Table 68. Bldg. 750, savings and payback summary, Climate Zone 5A (Chicago, IL).

\begin{tabular}{|l|c|c|c|c|c|}
\hline EEM & $\begin{array}{c}\text { Electrical } \\
\text { Savings } \\
(\mathbf{k W h} / \mathbf{y r})\end{array}$ & $\begin{array}{c}\text { Thermal } \\
\text { Savings } \\
\text { (Mil. Btu/yr) }\end{array}$ & $\begin{array}{c}\text { Annual Cost } \\
\text { Savings }\end{array}$ & $\begin{array}{c}\text { Implementation } \\
\text { Costs }\end{array}$ & $\begin{array}{c}\text { Payback } \\
\text { Period (yrs) }\end{array}$ \\
\hline Reduce Infiltration & 78,891 & 723 & $\$ 13,033$ & $\$ 24,930$ & 1.9 \\
\hline Lighting Controls & 39,585 & & $\$ 3,717$ & $\$ 36,556$ & 9.8 \\
\hline Roof/Attic Insulation & 245 & 15 & $\$ 140$ & $\$ 19,165$ & 137.2 \\
\hline Replacement of Chiller & 233,000 & 0 & $\$ 21,879$ & $\$ 163,800$ & 7.5 \\
\hline Replace Mechanical Equipment Controls & 592,487 & 736 & $\$ 61,361$ & $\$ 27,808$ & 0.5 \\
\hline Total & $\mathbf{9 4 4 , 2 0 8}$ & $\mathbf{1 , 4 7 4}$ & $\mathbf{\$ 1 0 0 , 1 2 9}$ & $\mathbf{2 7 2 , 2 5 9}$ & $\mathbf{2 . 7}$ \\
\hline
\end{tabular}

Table 69. Bldg. 750, savings and payback summary, Climate Zone 5B (Colorado Springs, CO).

\begin{tabular}{|l|c|c|c|c|c|}
\hline EEM & $\begin{array}{c}\text { Electrical } \\
\text { Savings } \\
(\mathrm{kWh} / \mathrm{yr})\end{array}$ & $\begin{array}{c}\text { Thermal } \\
\text { Savings } \\
(\text { Mil. Btu/yr) }\end{array}$ & $\begin{array}{c}\text { Annual Cost } \\
\text { Savings }\end{array}$ & $\begin{array}{c}\text { Implementation } \\
\text { Costs }\end{array}$ & $\begin{array}{c}\text { Payback } \\
\text { Period (yrs) }\end{array}$ \\
\hline Reduce Infiltration & 41,851 & 575 & $\$ 8,403$ & $\$ 24,930$ & 3.0 \\
\hline Lighting Controls & 39,585 & & $\$ 3,717$ & $\$ 36,556$ & 9.8 \\
\hline Roof/Attic Insulation & 371 & 19 & $\$ 183$ & $\$ 19,165$ & 104.9 \\
\hline Replacement of Chiller & 200,000 & 0 & $\$ 18,780$ & $\$ 126,000$ & 6.7 \\
\hline Replace Mechanical Equipment Controls & 566,321 & 700 & $\$ 58,624$ & $\$ 27,808$ & 0.5 \\
\hline Total & $\mathbf{8 4 8 , 1 2 8}$ & 1,294 & $\$ 89,707$ & $\mathbf{2 3 4 , 4 5 9}$ & $\mathbf{2 . 6}$ \\
\hline
\end{tabular}

Table 70. Bldg. 750, savings and payback summary, Climate Zone 6A (Burlington, VT).

\begin{tabular}{|l|c|c|c|c|c|}
\hline EEM & $\begin{array}{c}\text { Electrical } \\
\text { Savings } \\
(\mathbf{k W h} / \mathbf{y r})\end{array}$ & $\begin{array}{c}\text { Thermal } \\
\text { Savings } \\
(\text { Mil. Btu/yr) }\end{array}$ & $\begin{array}{c}\text { Annual Cost } \\
\text { Savings }\end{array}$ & $\begin{array}{c}\text { Implementation } \\
\text { Costs }\end{array}$ & $\begin{array}{c}\text { Payback } \\
\text { Period (yrs) }\end{array}$ \\
\hline Reduce Infiltration & 80,029 & 851 & $\$ 14,136$ & $\$ 24,930$ & 1.8 \\
\hline Lighting Controls & 39,585 & & $\$ 3,717$ & $\$ 36,556$ & 9.8 \\
\hline Roof/Attic Insulation & 215 & 21 & $\$ 184$ & $\$ 19,165$ & 104.4 \\
\hline Replacement of Chiller & 211,000 & 0 & $\$ 19,813$ & $\$ 163,800$ & 8.3 \\
\hline Replace Mechanical Equipment Controls & 567,676 & 717 & $\$ 58,883$ & $\$ 27,808$ & 0.5 \\
\hline Total & 898,505 & 1,589 & $\$ 96,732$ & $\mathbf{2 7 2 , 2 5 9}$ & 2.8 \\
\hline
\end{tabular}

Table 71. Bldg. 750, savings and payback summary, Climate Zone 6B (Helena, MT).

\begin{tabular}{|l|c|c|c|c|c|}
\hline EEM & $\begin{array}{c}\text { Electrical } \\
\text { Savings } \\
(\mathrm{kWh} / \mathrm{yr})\end{array}$ & $\begin{array}{c}\text { Thermal } \\
\text { Savings } \\
(\text { Mil. Btu/yr) }\end{array}$ & $\begin{array}{c}\text { Annual Cost } \\
\text { Savings }\end{array}$ & $\begin{array}{c}\text { Implementation } \\
\text { Costs }\end{array}$ & $\begin{array}{c}\text { Payback } \\
\text { Period (yrs) }\end{array}$ \\
\hline Reduce Infiltration & 92,532 & 764 & $\$ 14,633$ & $\$ 24,930$ & 1.7 \\
\hline Lighting Controls & 39,585 & & $\$ 3,717$ & $\$ 36,556$ & 9.8 \\
\hline Roof/Attic Insulation & 244 & 31 & $\$ 264$ & $\$ 19,165$ & 72.6 \\
\hline Replacement of Chiller & 200,000 & 0 & $\$ 18,780$ & $\$ 126,000$ & 6.7 \\
\hline Replace Mechanical Equipment Controls & 563,223 & 718 & $\$ 58,473$ & $\$ 27,808$ & 0.5 \\
\hline Total & $\mathbf{8 9 5 , 5 8 4}$ & $\mathbf{1 , 5 1 3}$ & $\mathbf{\$ 9 5 , 8 6 6}$ & $\mathbf{2 3 4 , 4 5 9}$ & $\mathbf{2 . 4}$ \\
\hline
\end{tabular}


Table 72. Bldg. 750, savings and payback summary, Climate Zone 7A (Duluth, MN).

\begin{tabular}{|l|c|c|c|c|c|}
\hline EEM & $\begin{array}{c}\text { Electrical } \\
\text { Savings } \\
(\mathbf{k W h} / \mathbf{y r})\end{array}$ & $\begin{array}{c}\text { Thermal } \\
\text { Savings } \\
(\text { Mil. Btu/yr) }\end{array}$ & $\begin{array}{c}\text { Annual Cost } \\
\text { Savings }\end{array}$ & $\begin{array}{c}\text { Implementation } \\
\text { Costs }\end{array}$ & $\begin{array}{c}\text { Payback } \\
\text { Period (yrs) }\end{array}$ \\
\hline Reduce Infiltration & 126,502 & 1,090 & $\$ 20,359$ & $\$ 24,930$ & 1.2 \\
\hline Lighting Controls & 39,585 & & $\$ 3,717$ & $\$ 36,556$ & 9.8 \\
\hline Roof/Attic Insulation & 153 & 21 & $\$ 178$ & $\$ 19,165$ & 107.8 \\
\hline Replacement of Chiller & 200,000 & 0 & $\$ 18,780$ & $\$ 163,800$ & 8.7 \\
\hline Replace Mechanical Equipment Controls & 553,472 & 687 & $\$ 57,316$ & $\$ 27,808$ & 0.5 \\
\hline Total & $\mathbf{9 1 9 , 7 1 2}$ & $\mathbf{1 , 7 9 8}$ & $\mathbf{\$ 1 0 0 , 3 4 9}$ & $\mathbf{2 7 2 , 2 5 9}$ & $\mathbf{2 . 7}$ \\
\hline
\end{tabular}

Table 73. Bldg. 750, savings and payback summary, Climate Zone 8 A (Fairbanks, AK).

\begin{tabular}{|l|c|c|c|c|c|}
\hline EEM & $\begin{array}{c}\text { Electrical } \\
\text { Savings } \\
(\mathbf{k W h} / \mathbf{y r})\end{array}$ & $\begin{array}{c}\text { Thermal } \\
\text { Savings } \\
(\text { Mil. Btu/yr) }\end{array}$ & $\begin{array}{c}\text { Annual Cost } \\
\text { Savings }\end{array}$ & $\begin{array}{c}\text { Implementation } \\
\text { Costs }\end{array}$ & $\begin{array}{c}\text { Payback } \\
\text { Period (yrs) }\end{array}$ \\
\hline Reduce Infiltration & 156,815 & 1,572 & $\$ 26,955$ & $\$ 24,930$ & 0.9 \\
\hline Lighting Controls & 39,585 & & $\$ 3,717$ & $\$ 36,556$ & 9.8 \\
\hline Roof/Attic Insulation & 235 & 73 & $\$ 590$ & $\$ 19,165$ & 32.5 \\
\hline Replacement of Chiller & 201,000 & 0 & $\$ 18,874$ & $\$ 138,600$ & 7.3 \\
\hline Replace Mechanical Equipment Controls & 529,301 & 114 & $\$ 50,588$ & $\$ 27,808$ & 0.5 \\
\hline Total & $\mathbf{9 2 6 , 9 3 6}$ & 1,759 & $\$ 100,724$ & 247,059 & 2.5 \\
\hline
\end{tabular}

Figure 36. Bldg. 750, annual cost savings resulting from EEM “Reduce Infiltration,” by climate zone.

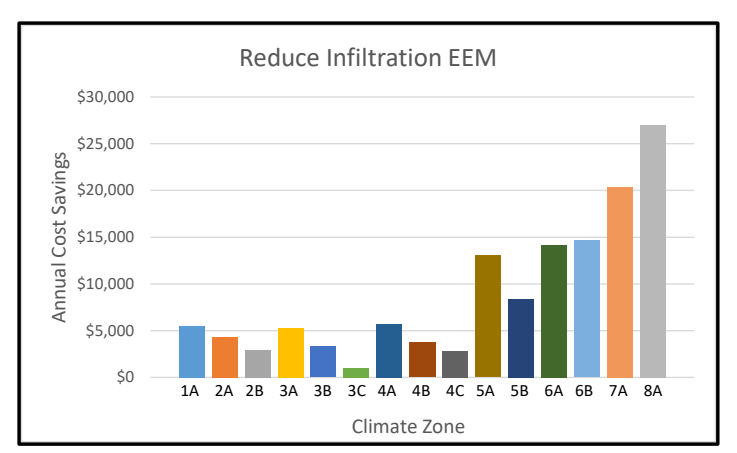

Figure 37. Bldg. 750, simple payback resulting from EEM “Reduce Infiltration,” by climate zone.

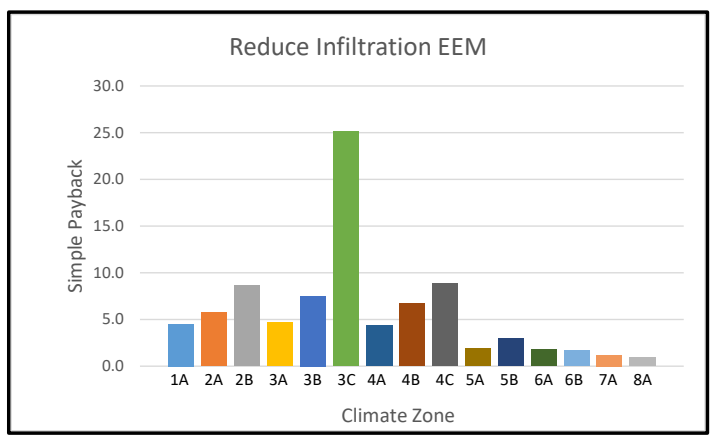


Figure 38. Bldg. 750 , annual cost savings resulting from EEM “Lighting Controls," by climate zone.

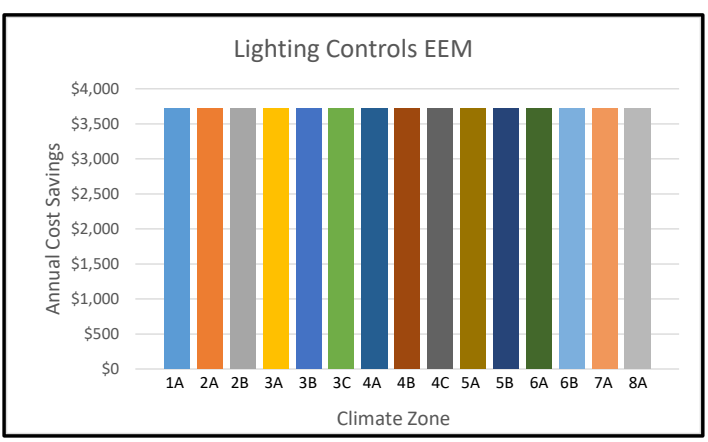

Figure 40. Bldg. 750, annual cost savings resulting from EEM "Roof/Attic Insulation," by climate zone.

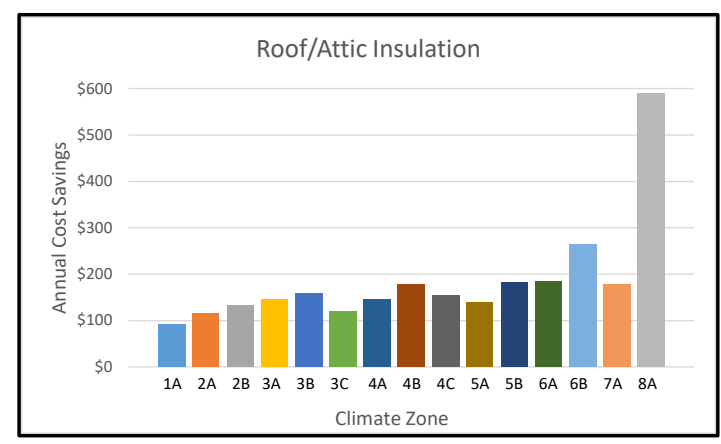

Figure 42. Bldg. 750 , annual cost savings resulting from EEM “Replace Chiller EEM," by climate zone.

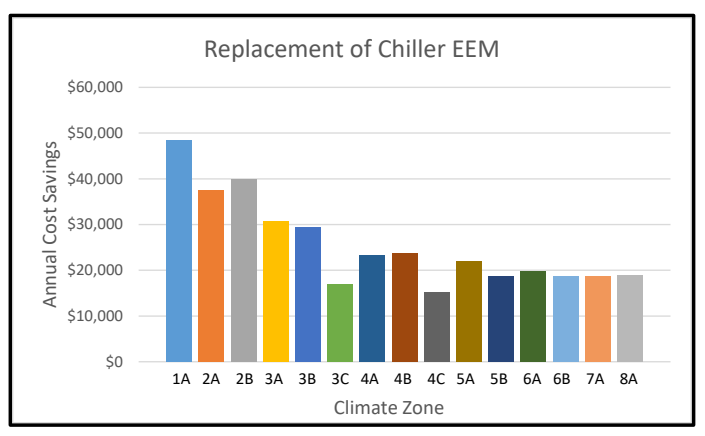

Figure 39. BIdg. 750 , simple payback resulting from EEM “Lighting Controls," by climate zone.

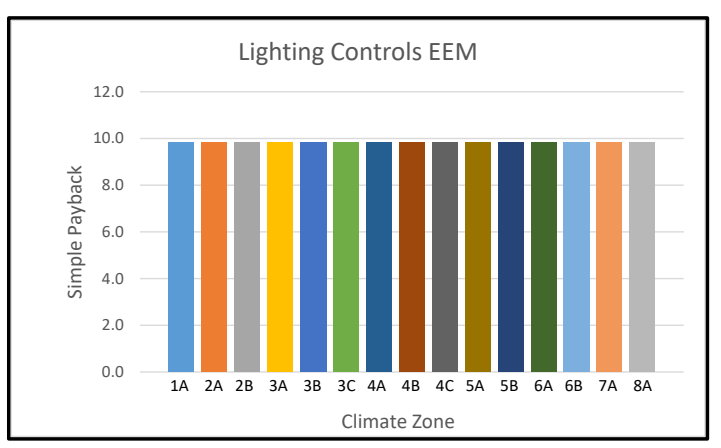

Figure 41. Bldg. 750 , simple payback resulting from EEM “Roof/Attic Insulation," by climate zone.

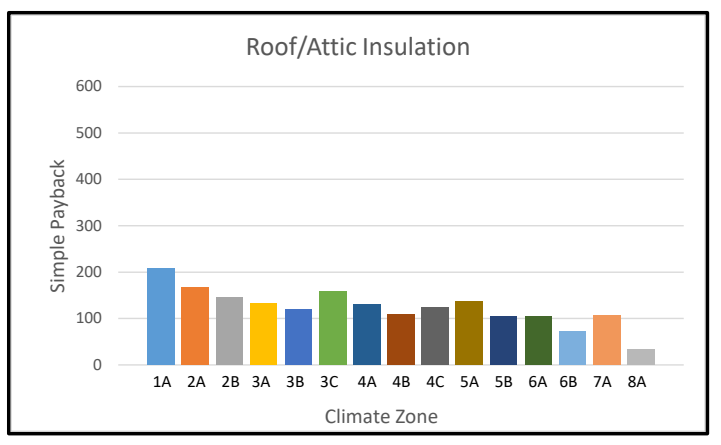

Figure 43. Bldg. 750 , simple payback resulting from EEM “Replace Chiller EEM," by climate zone.

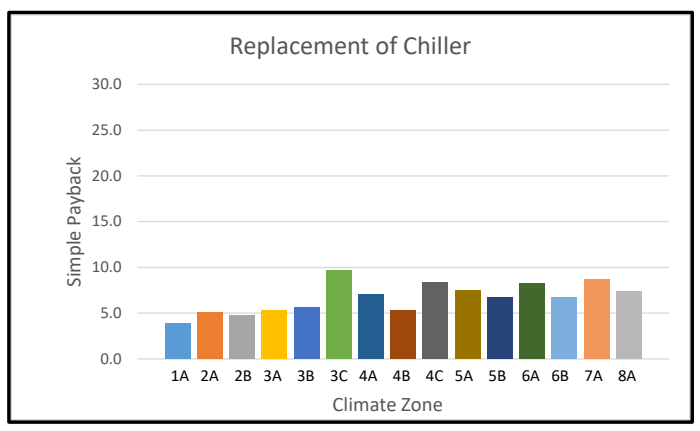


Figure 44. Bldg. 750, annual cost savings resulting from EEM "Replace Mechanical Equipment Controls EEM," by climate zone.

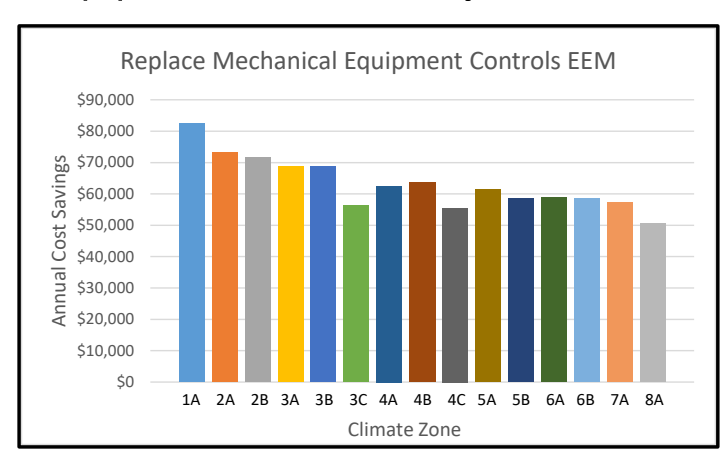

Figure 45. BIdg. 750 , simple payback resulting from EEM “Replace Mechanical Equipment Controls EEM," by climate zone.

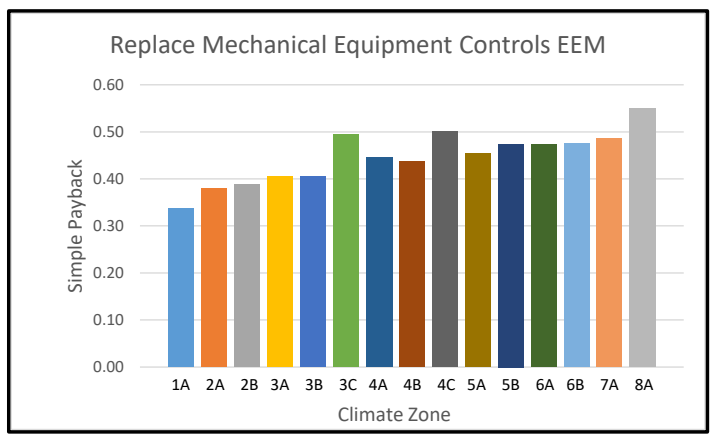

\subsubsection{Bldg. 1803 EEM savings by climate zone}

The EEMs chosen for Bldg. 1803 were:

- Reduce Infiltration. Infiltration of the building was changed from 2.00 ACH to 1.00 ACH. The implementation cost was calculated from 122 windows that are $3.3 \times 3 \mathrm{ft}$, and eight doors that are $3 \times 7 \mathrm{ft}$ for a total of $1641.2 \mathrm{ft}$, at a cost of $\$ 4.41 / \mathrm{ft}$.

- Roof/Attic Insulation. Add R-38 batt insulation to the roof, where previously there was no insulation. The cost of the insulation was found to be $\$ 1.93 / \mathrm{ft}^{2}$ in 2014, to which an escalation of $3 \%$ per year was added. With 9,087 $\mathrm{ft}^{2}$ of roof/attic area, the estimated cost is $\$ 19,165$.

- Replace Mechanical Equipment. Replace the building's heating and cooling equipment. The original state building used chilled water coils as the cooling source, and hot water coils as the heating source. The hot water source was a hot water loop. The EEM set the cooling and heating source as a heat pump. The heat pump source is a ground loop. Figure 46 shows the system specifications.

Using previous case studies and online estimates (Geothermal Genius 2009), the cost of installing six heat pumps with a total $205 \mathrm{MBH}$ heating capacity and 22 ton cooling capacity is $\$ 90,562$. Figure 46 shows the specifications. 
Figure 46. Heat pump specifications.

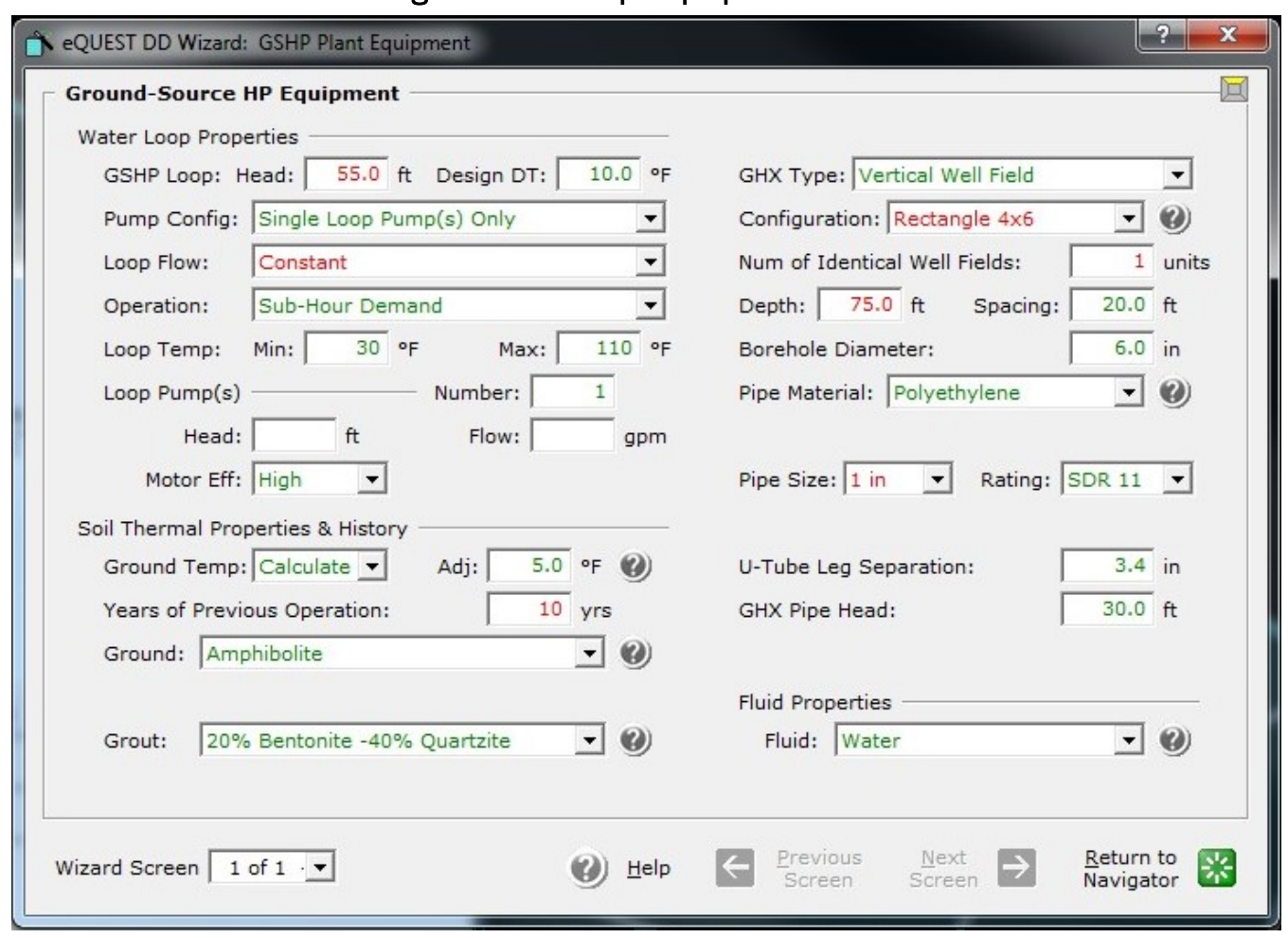

- Replace Mechanical Equipment Controls. Change the building from an occupancy of $24 \mathrm{hrs}$ per day every day of the week to an occupancy of 0800-1700 M-F, and unoccupied Sa-Su and on Holidays. It also changed the temperature setpoints from occupied and unoccupied cooling and heating of 76 and $70{ }^{\circ} \mathrm{F}$, to occupied cooling and heating of 78 and $68{ }^{\circ} \mathrm{F}$ and unoccupied cooling and heating of 85 and $55^{\circ} \mathrm{F}$, respectively. The HVAC system fans were set to operate 2 hours before open and 2 hours after close of the building. The fans were set to cycle at night with minimum Outside Air, to use an economizer, and to cycle on via control zones. A time clock for each AHU can be used to achieve the above recommendations. A cost of $\$ 3,900$ for the time clock and $\$ 1,392$ of fixed labor (based on previous experience) was assumed. For two AHUs, this cost is $\$ 10,584$.

- Lighting Controls. Energy audits of this facility indicated a large number of open areas that had potential for savings via occupancy sensors. A cost of $\$ 0.95 / \mathrm{ft}^{2}$ was used based on Zhang et al. (2013). With a facility area of $8,076 \mathrm{ft}^{2}$, the estimated cost is $\$ 7,672$.

The model was then run in each of the different climate zones using eQUEST. The results are listed in Tables 74-88 and shown in Figures 47-56. 
Table 74. Bldg. 1803, savings and payback summary, Climate Zone 1A (Miami, FL).

\begin{tabular}{|l|c|c|c|c|c|}
\hline EEM & $\begin{array}{c}\text { Electrical } \\
\text { Savings } \\
(\mathbf{k W h} / \mathbf{y r})\end{array}$ & $\begin{array}{c}\text { Thermal } \\
\text { Savings } \\
(\text { Mil. Btu/yr) }\end{array}$ & $\begin{array}{c}\text { Annual Cost } \\
\text { Savings }\end{array}$ & $\begin{array}{c}\text { Implementation } \\
\text { Costs }\end{array}$ & $\begin{array}{c}\text { Payback } \\
\text { Period (yrs) }\end{array}$ \\
\hline Reduce Infiltration & 21,864 & 49 & $\$ 2,434$ & $\$ 7,237.69$ & 3.0 \\
\hline Lighting Controls & 4,257 & 0 & $\$ 400$ & $\$ 7,672$ & 19.2 \\
\hline Roof/Attic Insulation & 442 & 0 & $\$ 42$ & $\$ 9,975.60$ & 240.4 \\
\hline $\begin{array}{l}\text { Replacement of Mechanical Equipment } \\
\text { (Heat Pump) }\end{array}$ & 111,921 & 309 & $\$ 12,913$ & $\$ 90,563$ & 7.0 \\
\hline Replace Mechanical Equipment Controls & 133,394 & 249 & $\$ 14,463$ & $\$ 10,584$ & 0.7 \\
\hline Total & 271,878 & 607 & $\$ 30,252$ & $\$ 126,031.99$ & 4.2 \\
\hline
\end{tabular}

Table 75. Bldg. 463, savings and payback summary, Climate Zone 2A (Houston, TX).

\begin{tabular}{|l|c|c|c|c|c|}
\hline EEM & $\begin{array}{c}\text { Electrical } \\
\text { Savings } \\
(\mathrm{kWh} / \mathrm{yr})\end{array}$ & $\begin{array}{c}\text { Thermal } \\
\text { Savings } \\
(\text { Mil. Btu/yr) }\end{array}$ & $\begin{array}{c}\text { Annual Cost } \\
\text { Savings }\end{array}$ & $\begin{array}{c}\text { Implementation } \\
\text { Costs }\end{array}$ & $\begin{array}{c}\text { Payback } \\
\text { Period (yrs) }\end{array}$ \\
\hline Reduce Infiltration & 56,197 & 387 & $\$ 8,288$ & $\$ 7,237.69$ & 0.9 \\
\hline Lighting Controls & 4,257 & 0 & $\$ 400$ & $\$ 7,672.20$ & 19.2 \\
\hline Roof/Attic Insulation & 280 & 3 & $\$ 50$ & $\$ 9,975.60$ & 201.0 \\
\hline $\begin{array}{l}\text { Replacement of Mechanical Equipment } \\
\text { (Heat Pump) }\end{array}$ & 183,158 & 751 & $\$ 23,041$ & $\$ 90,562.50$ & 3.9 \\
\hline Replace Mechanical Equipment Controls & 187,681 & 1,131 & $\$ 26,422$ & $\$ 10,584.00$ & 0.4 \\
\hline Total & $\mathbf{4 3 1 , 5 7 3}$ & $\mathbf{2 , 2 7 2}$ & $\$ 58,201$ & $\mathbf{1 2 6 , 0 3 2}$ & 2.2 \\
\hline
\end{tabular}

Table 76. Bldg. 1803, savings and payback summary, Climate Zone 2B (Phoenix, AZ).

\begin{tabular}{|l|c|c|c|c|c|}
\hline EEM & $\begin{array}{c}\text { Electrical } \\
\text { Savings } \\
(\mathbf{k W h} / \mathbf{y r})\end{array}$ & $\begin{array}{c}\text { Thermal } \\
\text { Savings } \\
(\text { Mil. Btu/yr) }\end{array}$ & $\begin{array}{c}\text { Annual Cost } \\
\text { Savings }\end{array}$ & $\begin{array}{c}\text { Implementation } \\
\text { Costs }\end{array}$ & $\begin{array}{c}\text { Payback } \\
\text { Period (yrs) }\end{array}$ \\
\hline Reduce Infiltration & 24,207 & 174 & $\$ 3,627$ & $\$ 7,237.69$ & 2.0 \\
\hline Lighting Controls & 4,257 & 0 & $\$ 400$ & $\$ 7,672.20$ & 19.2 \\
\hline Roof/Attic Insulation & 946 & 3 & $\$ 112$ & $\$ 9,975.60$ & 88.9 \\
\hline $\begin{array}{l}\text { Replacement of Mechanical Equipment } \\
\text { (Heat Pump) }\end{array}$ & 126,696 & 946 & $\$ 19,257$ & $\$ 90,562.50$ & 4.7 \\
\hline Replace Mechanical Equipment Controls & 128,085 & 626 & $\$ 16,897$ & $\$ 10,584.00$ & 0.6 \\
\hline Total & $\mathbf{2 8 4 , 1 9 1}$ & 1,749 & $\$ 40,293$ & $\mathbf{1 2 6 , 0 3 2}$ & 3.1 \\
\hline
\end{tabular}

Table 77. Bldg. 463, savings and payback summary, Climate Zone $3 \mathrm{~A}$ (Memphis, TN).

\begin{tabular}{|l|c|c|c|c|c|}
\hline EEM & $\begin{array}{c}\text { Electrical } \\
\text { Savings } \\
\mathbf{k W h / y r})\end{array}$ & $\begin{array}{c}\text { Thermal } \\
\text { Savings } \\
(\text { Mil. Btu/yr) }\end{array}$ & $\begin{array}{c}\text { Annual Cost } \\
\text { Savings }\end{array}$ & $\begin{array}{c}\text { Implementation } \\
\text { Costs }\end{array}$ & $\begin{array}{c}\text { Payback } \\
\text { Period (yrs) }\end{array}$ \\
\hline Reduce Infiltration & 48,269 & 424 & $\$ 7,831$ & $\$ 7,237.69$ & 0.9 \\
\hline Lighting Controls & 4,257 & 0 & $\$ 400$ & $\$ 7,672.20$ & 19.2 \\
\hline Roof/Attic Insulation & 276 & 4 & $\$ 57$ & $\$ 9,975.60$ & 174.9 \\
\hline $\begin{array}{l}\text { Replacement of Mechanical Equipment } \\
\text { (Heat Pump) }\end{array}$ & 185,775 & 2,552 & $\$ 37,299$ & $\$ 90,562.50$ & 2.4 \\
\hline Replace Mechanical Equipment Controls & 192,357 & 1,455 & $\$ 29,382$ & $\$ 10,584.00$ & 0.4 \\
\hline Total & 430,934 & 4,435 & $\$ 74,969$ & 126,032 & 1.7 \\
\hline
\end{tabular}


Table 78. Bldg. 1803, savings and payback summary, Climate Zone 3B (El Paso, TX).

\begin{tabular}{|l|c|c|c|c|c|}
\hline EEM & $\begin{array}{c}\text { Electrical } \\
\text { Savings } \\
(\mathbf{k W h} / \mathbf{y r})\end{array}$ & $\begin{array}{c}\text { Thermal } \\
\text { Savings } \\
(\text { Mil. Btu/yr) }\end{array}$ & $\begin{array}{c}\text { Annual Cost } \\
\text { Savings }\end{array}$ & $\begin{array}{c}\text { Implementation } \\
\text { Costs }\end{array}$ & $\begin{array}{c}\text { Payback } \\
\text { Period (yrs) }\end{array}$ \\
\hline Reduce Infiltration & 39,226 & 352 & $\$ 6,422$ & $\$ 7,237.69$ & 1.1 \\
\hline Lighting Controls & 4,257 & 0 & $\$ 400$ & $\$ 7,672.20$ & 19.2 \\
\hline Roof/Attic Insulation & 564 & 5 & $\$ 92$ & $\$ 9,975.60$ & 108.6 \\
\hline $\begin{array}{l}\text { Replacement of Mechanical Equipment } \\
\text { (Heat Pump) }\end{array}$ & 142,830 & 794 & $\$ 19,589$ & $\$ 90,562.50$ & 4.6 \\
\hline Replace Mechanical Equipment Controls & 159,636 & 1,074 & $\$ 23,346$ & $\$ 10,584.00$ & 0.5 \\
\hline Total & 346,513 & 2,225 & $\$ 49,848$ & $\mathbf{1 2 6 , 0 3 2}$ & 2.5 \\
\hline
\end{tabular}

Table 79. Bldg. 1803, savings and payback summary, Climate Zone $3 C$ (San Francisco, CA).

\begin{tabular}{|l|c|c|c|c|c|}
\hline EEM & $\begin{array}{c}\text { Electrical } \\
\text { Savings } \\
(\mathbf{k W h} / \mathbf{y r})\end{array}$ & $\begin{array}{c}\text { Thermal } \\
\text { Savings } \\
(\text { Mil. Btu/yr) }\end{array}$ & $\begin{array}{c}\text { Annual Cost } \\
\text { Savings }\end{array}$ & $\begin{array}{c}\text { Implementation } \\
\text { Costs }\end{array}$ & $\begin{array}{c}\text { Payback } \\
\text { Period (yrs) }\end{array}$ \\
\hline Reduce Infiltration & 14,296 & 264 & $\$ 3,396$ & $\$ 7,237.69$ & 2.1 \\
\hline Lighting Controls & 4,257 & 0 & $\$ 400$ & $\$ 7,672.20$ & 19.2 \\
\hline Roof/Attic Insulation & 193 & 5 & $\$ 57$ & $\$ 9,975.60$ & 174.9 \\
\hline $\begin{array}{l}\text { Replacement of Mechanical Equipment } \\
\text { (Heat Pump) }\end{array}$ & 76,051 & 927 & $\$ 14,353$ & $\$ 90,562.50$ & 6.3 \\
\hline Replace Mechanical Equipment Controls & 129,093 & 1,179 & $\$ 21,294$ & $\$ 10,584.00$ & 0.5 \\
\hline Total & $\mathbf{2 2 3 , 8 9 0}$ & $\mathbf{2 , 3 7 5}$ & $\$ 39,501$ & $\mathbf{1 2 6 , 0 3 2}$ & 3.2 \\
\hline
\end{tabular}

Table 80. Bldg. 1803, savings and payback summary, Climate Zone 4A (Baltimore, MD).

\begin{tabular}{|l|c|c|c|c|c|}
\hline EEM & $\begin{array}{c}\text { Electrical } \\
\text { Savings } \\
(\mathbf{k W h} / \mathbf{y r})\end{array}$ & $\begin{array}{c}\text { Thermal } \\
\text { Savings } \\
(\text { Mil. Btu/yr) }\end{array}$ & $\begin{array}{c}\text { Annual Cost } \\
\text { Savings }\end{array}$ & $\begin{array}{c}\text { Implementation } \\
\text { Costs }\end{array}$ & $\begin{array}{c}\text { Payback } \\
\text { Period (yrs) }\end{array}$ \\
\hline Reduce Infiltration & 38,238 & 436 & $\$ 6,983$ & $\$ 7,237.69$ & 1.0 \\
\hline Lighting Controls & 4,257 & 0 & $\$ 400$ & $\$ 7,672.20$ & 19.2 \\
\hline Roof/Attic Insulation & 239 & 4 & $\$ 54$ & $\$ 9,975.60$ & 186.2 \\
\hline $\begin{array}{l}\text { Replacement of Mechanical Equipment } \\
\text { (Heat Pump) }\end{array}$ & 173,946 & 3,410 & $\$ 42,863$ & $\$ 90,562.50$ & 2.1 \\
\hline Replace Mechanical Equipment Controls & 182,929 & 1,666 & $\$ 30,139$ & $\$ 10,584.00$ & 0.4 \\
\hline Total & 399,609 & 5,516 & $\$ 80,438$ & 126,032 & 1.6 \\
\hline
\end{tabular}

Table 81. Bldg. 1803, savings and payback summary, Climate Zone 4B (Albuquerque, NM).

\begin{tabular}{|l|l|l|l|l|l|}
\hline EEM & $\begin{array}{c}\text { Electrical } \\
\text { Savings } \\
(\mathbf{k W h} / \mathbf{y r})\end{array}$ & $\begin{array}{c}\text { Thermal } \\
\text { Savings } \\
(\text { Mil. Btu/yr) }\end{array}$ & $\begin{array}{c}\text { Annual Cost } \\
\text { Savings }\end{array}$ & $\begin{array}{c}\text { Implementation } \\
\text { Costs }\end{array}$ & $\begin{array}{c}\text { Payback } \\
\text { Period (yrs) }\end{array}$ \\
\hline Reduce Infiltration & 41,190 & 460 & $\$ 7,447$ & $\$ 7,237.69$ & 1.0 \\
\hline Lighting Controls & 4,257 & 0 & $\$ 400$ & $\$ 7,672.20$ & 19.2 \\
\hline Roof/Attic Insulation & 359 & 4 & $\$ 65$ & $\$ 9,975.60$ & 153.9 \\
\hline $\begin{array}{l}\text { Replacement of Mechanical Equipment } \\
\text { (Heat Pump) }\end{array}$ & 135,727 & 2,652 & $\$ 33,377$ & $\$ 90,562.50$ & 2.7 \\
\hline Replace Mechanical Equipment Controls & 163,002 & 1,357 & $\$ 25,863$ & $\$ 10,584.00$ & 0.4 \\
\hline Total & 344,535 & 4,473 & $\$ 67,152$ & 126,032 & 1.9 \\
\hline
\end{tabular}


Table 82. Bldg. 1803, savings and payback summary, Climate Zone 4C (Seattle, WA).

\begin{tabular}{|l|c|c|c|c|c|}
\hline EEM & $\begin{array}{c}\text { Electrical } \\
\text { Savings } \\
(\mathrm{kWh} / \mathbf{y r})\end{array}$ & $\begin{array}{c}\text { Thermal } \\
\text { Savings } \\
(\text { Mil. Btu/yr) }\end{array}$ & $\begin{array}{c}\text { Annual Cost } \\
\text { Savings }\end{array}$ & $\begin{array}{c}\text { Implementation } \\
\text { Costs }\end{array}$ & $\begin{array}{c}\text { Payback } \\
\text { Period (yrs) }\end{array}$ \\
\hline Reduce Infiltration & 27,380 & 410 & $\$ 5,761$ & $\$ 7,237.69$ & 1.3 \\
\hline Lighting Controls & 4,257 & 0 & $\$ 400$ & $\$ 7,672.20$ & 19.2 \\
\hline Roof/Attic Insulation & 222 & 5 & $\$ 60$ & $\$ 9,975.60$ & 167.0 \\
\hline $\begin{array}{l}\text { Replacement of Mechanical Equipment } \\
\text { (Heat Pump) }\end{array}$ & 98,646 & 2,828 & $\$ 31,265$ & $\$ 90,562.50$ & 2.9 \\
\hline Replace Mechanical Equipment Controls & 133,422 & 1,357 & $\$ 23,086$ & $\$ 10,584.00$ & 0.5 \\
\hline Total & $\mathbf{2 6 3 , 9 2 7}$ & $\mathbf{4 , 6 0 0}$ & $\$ 60,571$ & $\mathbf{1 2 6 , 0 3 2}$ & 2.1 \\
\hline
\end{tabular}

Table 83. Bldg. 1803, savings and payback summary, Climate Zone 5A (Chicago, IL).

\begin{tabular}{|l|c|c|c|c|c|}
\hline & $\begin{array}{c}\text { Electrical } \\
\text { Savings } \\
(\mathbf{k W h} / \mathbf{y r})\end{array}$ & $\begin{array}{c}\text { Thermal } \\
\text { Savings } \\
\text { EEM }\end{array}$ & $\begin{array}{c}\text { Annual Cost } \\
\text { Stu/yr) }\end{array}$ & $\begin{array}{c}\text { Implementation } \\
\text { Costs }\end{array}$ & $\begin{array}{c}\text { Payback } \\
\text { Period (yrs) }\end{array}$ \\
\hline Reduce Infiltration & 67,264 & 780 & $\$ 12,384$ & $\$ 7,237.69$ & 0.6 \\
\hline Lighting Controls & 4,257 & 0 & $\$ 400$ & $\$ 7,672.20$ & 19.2 \\
\hline Roof/Attic Insulation & 214 & 5 & $\$ 59$ & $\$ 9,975.60$ & 169.1 \\
\hline $\begin{array}{l}\text { Replacement of Mechanical Equipment } \\
\text { (Heat Pump) }\end{array}$ & 231,775 & 4,808 & $\$ 59,170$ & $\$ 90,562.50$ & 1.5 \\
\hline Replace Mechanical Equipment Controls & 215,726 & 2,245 & $\$ 37,723$ & $\$ 10,584.00$ & 0.3 \\
\hline Total & 519,236 & 7,838 & $\$ 109,736$ & 126,032 & 1.1 \\
\hline
\end{tabular}

Table 84. Bldg. 1803, savings and payback summary, Climate Zone 5B (Colorado Springs, $\mathrm{CO})$.

\begin{tabular}{|l|c|c|c|c|c|}
\hline EEM & $\begin{array}{c}\text { Electrical } \\
\text { Savings } \\
(\mathbf{k W h} / \mathbf{y r})\end{array}$ & $\begin{array}{c}\text { Thermal } \\
\text { Savings } \\
(\mathrm{Mil.Btu} / \mathrm{yr})\end{array}$ & $\begin{array}{c}\text { Annual Cost } \\
\text { Savings }\end{array}$ & $\begin{array}{c}\text { Implementation } \\
\text { Costs }\end{array}$ & $\begin{array}{c}\text { Payback } \\
\text { Period (yrs) }\end{array}$ \\
\hline Reduce Infiltration & 29,353 & 415 & $\$ 5,985$ & $\$ 7,237.69$ & 1.2 \\
\hline Lighting Controls & 4,257 & 0 & $\$ 400$ & $\$ 7,672.20$ & 19.2 \\
\hline Roof/Attic Insulation & 215 & 4 & $\$ 51$ & $\$ 9,975.60$ & 194.4 \\
\hline $\begin{array}{l}\text { Replacement of Mechanical Equipment } \\
\text { (Heat Pump) }\end{array}$ & 186,201 & 4,077 & $\$ 49,203$ & $\$ 90,562.50$ & 1.8 \\
\hline Replace Mechanical Equipment Controls & 191,016 & 1,944 & $\$ 33,061$ & $\$ 10,584.00$ & 0.3 \\
\hline Total & 411,042 & 6,440 & $\$ 88,700$ & 126,032 & 1.4 \\
\hline
\end{tabular}

Table 85. Bldg. 1803, savings and payback summary, Climate Zone 6A (Burlington, VT).

\begin{tabular}{|l|c|c|c|c|c|}
\hline EEM & $\begin{array}{c}\text { Electrical } \\
\text { Savings } \\
(\mathrm{kWh} / \mathrm{yr})\end{array}$ & $\begin{array}{c}\text { Thermal } \\
\text { Savings } \\
\text { (Mil. Btu/yr) }\end{array}$ & $\begin{array}{c}\text { Annual Cost } \\
\text { Savings }\end{array}$ & $\begin{array}{c}\text { Implementation } \\
\text { Costs }\end{array}$ & $\begin{array}{c}\text { Payback } \\
\text { Period (yrs) }\end{array}$ \\
\hline Reduce Infiltration & 63,089 & 793 & $\$ 12,094$ & $\$ 7,237.69$ & 0.6 \\
\hline Lighting Controls & 4,257 & 0 & $\$ 400$ & $\$ 7,672.20$ & 19.2 \\
\hline Roof/Attic Insulation & 156 & 6 & $\$ 61$ & $\$ 9,975.60$ & 162.7 \\
\hline $\begin{array}{l}\text { Replacement of Mechanical Equipment } \\
\text { (Heat Pump) }\end{array}$ & 242,200 & 5,177 & $\$ 63,020$ & $\$ 90,562.50$ & 1.4 \\
\hline Replace Mechanical Equipment Controls & 211,620 & 2,248 & $\$ 37,361$ & $\$ 10,584.00$ & 0.3 \\
\hline Total & 521,322 & $\mathbf{8 , 2 2 4}$ & $\$ 112,935$ & 126,032 & 1.1 \\
\hline
\end{tabular}


Table 86. Bldg. 1803, savings and payback summary, Climate Zone 6B (Helena, MT).

\begin{tabular}{|c|c|c|c|c|c|}
\hline EEM & $\begin{array}{l}\text { Electrical } \\
\text { Savings } \\
\text { (kWh/yr) }\end{array}$ & $\begin{array}{c}\text { Thermal } \\
\text { Savings } \\
\text { (Mil. Btu/yr) }\end{array}$ & $\begin{array}{c}\text { Annual Cost } \\
\text { Savings }\end{array}$ & $\begin{array}{c}\text { Implementation } \\
\text { Costs }\end{array}$ & $\begin{array}{c}\text { Payback } \\
\text { Period (yrs) }\end{array}$ \\
\hline Reduce Infiltration & 63,662 & 795 & $\$ 12,163$ & $\$ 7,237.69$ & 0.6 \\
\hline Lighting Controls & 4,257 & 0 & $\$ 400$ & $\$ 7,672.20$ & 19.2 \\
\hline Roof/Attic Insulation & 315 & 11 & $\$ 115$ & $\$ 9,975.60$ & 86.6 \\
\hline $\begin{array}{l}\text { Replacement of Mechanical Equipment } \\
\text { (Heat Pump) }\end{array}$ & 228,089 & 4,988 & $\$ 60,224$ & $\$ 90,562.50$ & 1.5 \\
\hline Replace Mechanical Equipment Controls & 204,222 & 2,214 & $\$ 36,401$ & $\$ 10,584.00$ & 0.3 \\
\hline Total & 500,545 & 8,008 & $\$ 109,303$ & 126,032 & 1.2 \\
\hline
\end{tabular}

Table 87. Bldg. 1803, savings and payback summary, Climate Zone 7A (Duluth, MN).

\begin{tabular}{|l|c|c|c|c|c|}
\hline & $\begin{array}{c}\text { Electrical } \\
\text { Savings } \\
(\mathrm{kWh} / \mathrm{yr})\end{array}$ & $\begin{array}{c}\text { Thermal } \\
\text { Savings } \\
\text { (Mil. Btu/yr) }\end{array}$ & $\begin{array}{c}\text { Annual Cost } \\
\text { Savings }\end{array}$ & $\begin{array}{c}\text { Implementation } \\
\text { Costs }\end{array}$ & $\begin{array}{c}\text { Payback } \\
\text { Period (yrs) }\end{array}$ \\
\hline Reduce Infiltration & 72,439 & 951 & $\$ 14,201$ & $\$ 7,237.69$ & 0.5 \\
\hline Lighting Controls & 4,257 & 0 & $\$ 400$ & $\$ 7,672.20$ & 19.2 \\
\hline Roof/Attic Insulation & 66 & 5 & $\$ 45$ & $\$ 9,975.60$ & 221.2 \\
\hline $\begin{array}{l}\text { Replacement of Mechanical Equipment } \\
\text { (Heat Pump) }\end{array}$ & 288,517 & 6,274 & $\$ 75,903$ & $\$ 90,562.50$ & 1.2 \\
\hline Replace Mechanical Equipment Controls & 215,663 & 2,511 & $\$ 39,786$ & $\$ 10,584.00$ & 0.3 \\
\hline Total & 580,942 & 9,741 & $\$ 130,335$ & 126,032 & 1.0 \\
\hline
\end{tabular}

Table 88. Bldg. 1803, savings and payback summary, Climate Zone 8A (Fairbanks, AK).

\begin{tabular}{|l|c|c|c|c|c|}
\hline EEM & $\begin{array}{c}\text { Electrical } \\
\text { Savings } \\
\mathbf{k W h / y r )}\end{array}$ & $\begin{array}{c}\text { Thermal } \\
\text { Savings } \\
(\text { Mil. Btu/yr) }\end{array}$ & $\begin{array}{c}\text { Annual Cost } \\
\text { Savings }\end{array}$ & $\begin{array}{c}\text { Implementation } \\
\text { Costs }\end{array}$ & $\begin{array}{c}\text { Payback } \\
\text { Period (yrs) }\end{array}$ \\
\hline Reduce Infiltration & 103,542 & 1,384 & $\$ 20,490$ & $\$ 7,237.69$ & 0.4 \\
\hline Lighting Controls & 4,257 & 0 & $\$ 400$ & $\$ 7,672.20$ & 19.2 \\
\hline Roof/Attic Insulation & -93 & 20 & $\$ 147$ & $\$ 9,975.60$ & 67.9 \\
\hline $\begin{array}{l}\text { Replacement of Mechanical Equipment } \\
\text { (Heat Pump) }\end{array}$ & 367,420 & 7,732 & $\$ 94,656$ & $\$ 90,562.50$ & 1.0 \\
\hline Replace Mechanical Equipment Controls & 243,328 & 2,753 & $\$ 44,267$ & $\$ 10,584.00$ & 0.2 \\
\hline Total & 718,454 & 11,889 & $\$ 159,959$ & 126,032 & 0.8 \\
\hline
\end{tabular}


Figure 47. BIdg. 1803, annual cost savings resulting from EEM “Reduce Infiltration," by climate zone.

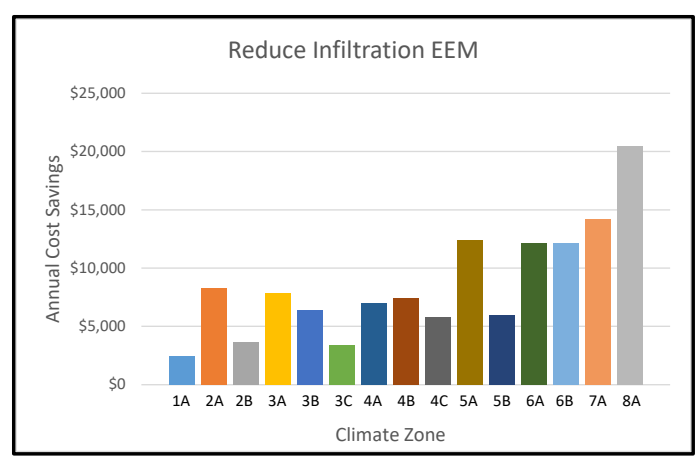

Figure 49. Bldg. 1803, annual cost savings resulting from EEM “Lighting Controls," by climate zone.

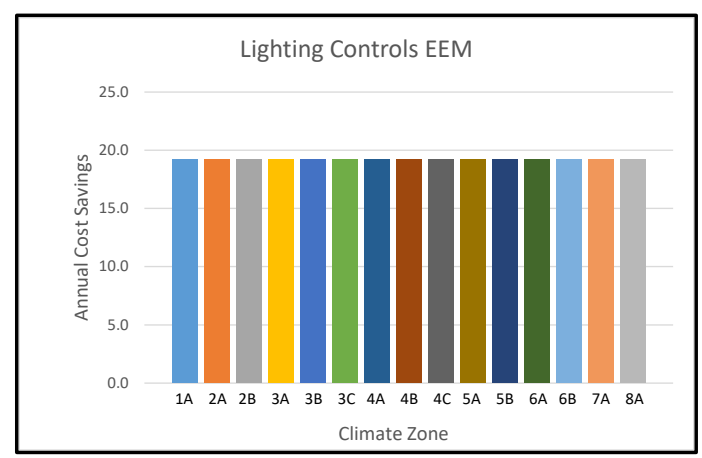

Figure 51. Bldg. 1803, annual cost savings resulting from EEM “Roof/Attic Insulation," by climate zone.

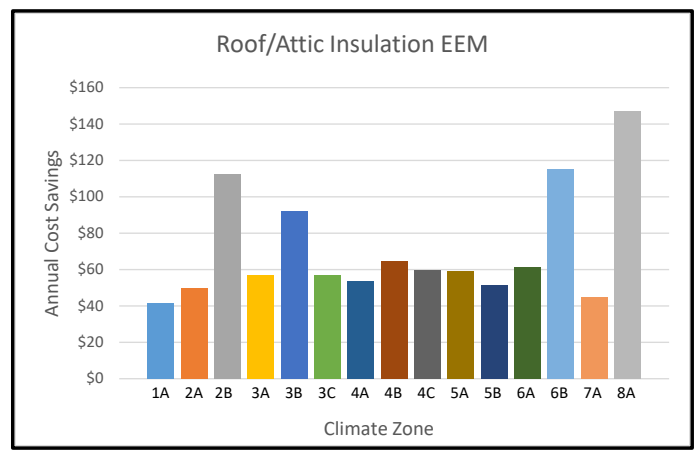

Figure 48. Bldg. 1803, simple payback resulting from EEM “Reduce Infiltration," by climate zone.

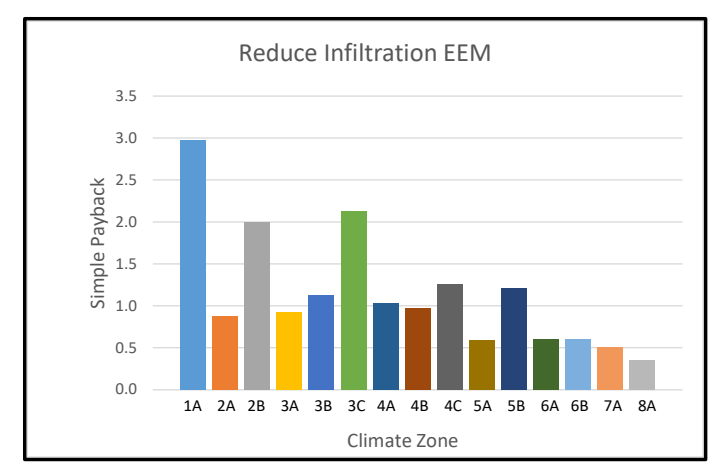

Figure 50. Bldg. 1803, simple payback resulting from EEM “Lighting Controls," by climate zone.

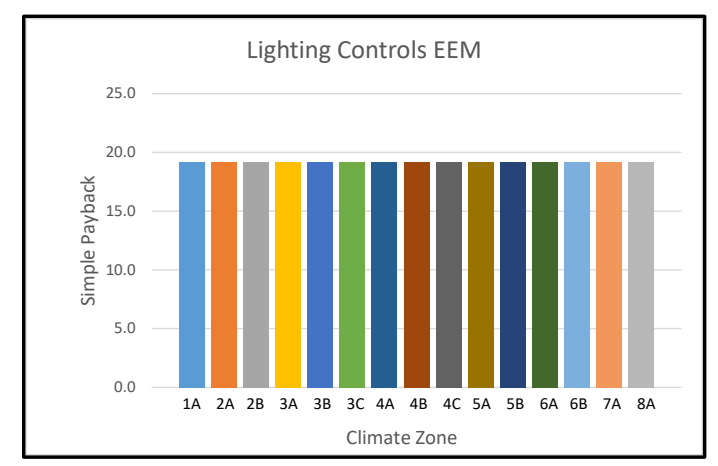

Figure 52. Bldg. 1803, simple payback resulting from EEM “Roof/Attic Insulation," by climate zone.

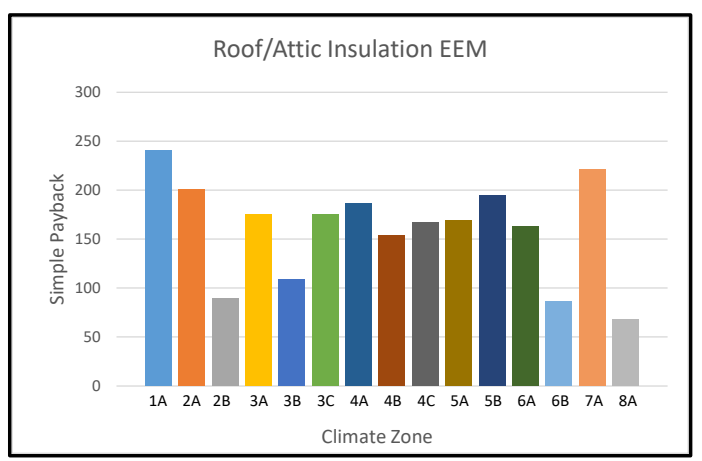


Figure 53. Bldg. 1803, annual cost savings resulting from EEM “Replace Mechanical Equipment EEM," by climate zone.

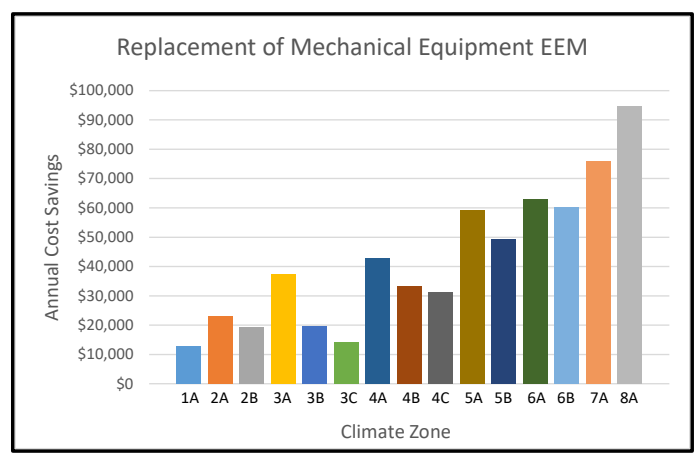

Figure 55. Bldg. 1803, annual cost savings resulting from EEM “Replace Mechanical Equipment Controls EEM," by climate zone.

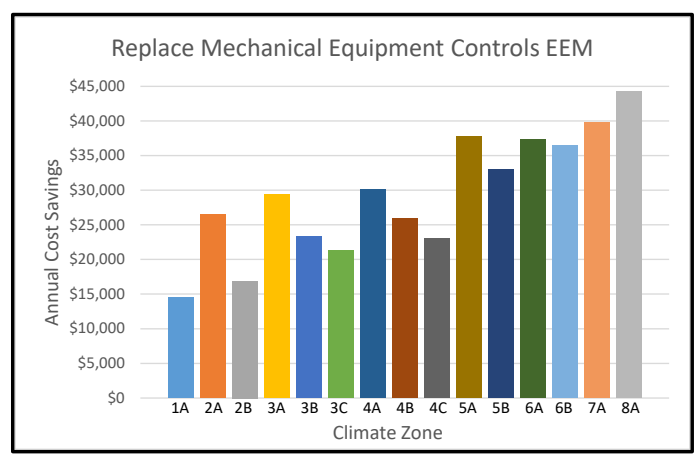

Figure 54. Bldg. 1803, simple payback resulting from EEM "Replace Mechanical Equipment EEM," by climate zone.

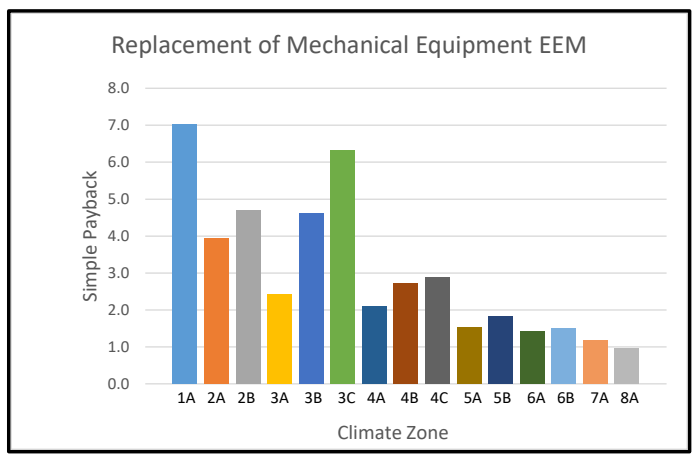

Figure 56. Bldg. 1803, simple payback resulting from EEM "Replace Mechanical Equipment Controls EEM," by climate zone.

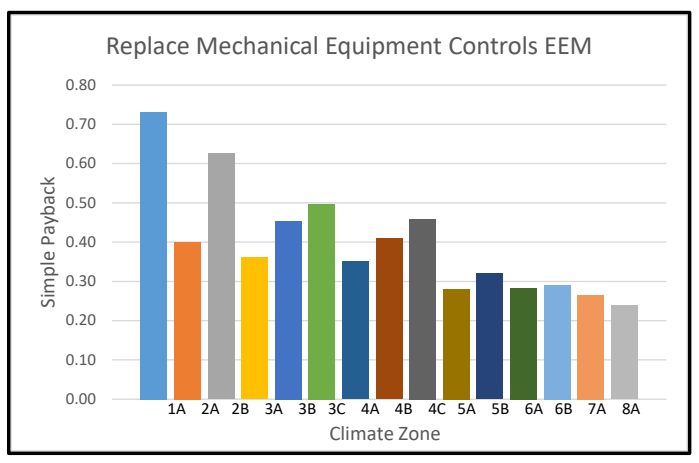

\subsubsection{Bldg. 3419 EEM savings by climate zone}

The EEMs chosen for Bldg. 3419 were:

- Reduce Infiltration. Infiltration of the building was changed from 2.00 ACH to 1.00 ACH. The implementation cost was calculated from an estimated 52 windows that are $3.33 \times 6.5 \mathrm{ft}$, and four doors that are $6 \times 7 \mathrm{ft}$ for a total of $1098.32 \mathrm{ft}$, at a cost of $\$ 4.41 / \mathrm{ft}$.

- Replacement of Mechanical Equipment. Replaced the building's $80 \%$ efficiency boiler with a boiler that is 95\% efficient. Using RSMeans, the costs to replace a 2,000 $\mathrm{MBH}$ boiler are estimated at $\$ 29,900$ for equipment and $\$ 7,475$ for labor, summing to a total cost of $\$ 37,375$.

- Install PV panels on roof. Building 3419 is a three story building with a flat roof. Panels can be installed on approximately $70 \%$ of the roof without being easily seen from ground level. 
- Replace Mechanical Equipment Controls. Change the building from an occupancy of $24 \mathrm{hrs}$ per day every day of the week to an occupancy of 0700-1800 M-F, and unoccupied Sa-Su and on Holidays. It also changed the temperature setpoints from occupied and unoccupied cooling and heating of 76 and $74{ }^{\circ} \mathrm{F}$, to occupied cooling and heating of 78 and $68{ }^{\circ} \mathrm{F}$ and unoccupied cooling and heating of 85 and $55^{\circ} \mathrm{F}$, respectively. The HVAC system fans were set to operate 2 hours before open and 2 hours after close of the building. A time clock for each AHU can be used to achieve the above recommendations. A cost of $\$ 3,900$ for the time clock and $\$ 1,392$ of fixed labor (based on previous experience) was assumed. For five AHUs, this cost is $\$ 26,460$.

- Lighting Controls. Energy audits of this facility indicated a large number of open areas that had potential for savings via occupancy sensors. A cost of $\$ 0.95 / \mathrm{ft}^{2}$ was used based on Zhang et al. (2013). With a facility area of $37,735 \mathrm{ft}^{2}$, the estimated cost is $\$ 35,848$.

- Install PV panels on Roof. Building 3419 has a flat roof and is high enough so PV panels can be installed on the roof and not be seen from the ground. The System Advisory Model (SAM) program developed by the National Renewable Energy Laboratory (NREL) was used to determine the amount of electricity that could be produced. The cost of PV systems has dropped dramatically recently, and for a small commercial system is estimated to be $\$ 3,500 / \mathrm{kW}$ of capacity, the maximum instantaneous production (Barbose and Darghouth 2016). The roof is approximately $13,000 \mathrm{ft}^{2}$. Due to some obstructions such as exhaust vents and a setback requirement so that the panels are not easily seen from ground level is estimated that $70 \%$ or roughly $9,000 \mathrm{ft}^{2}$ could have panels installed. It would have a maximum production capacity of $84 \mathrm{~kW}$. A typical PV panel has a capacity of $1 \mathrm{~kW} / 107 \mathrm{ft}^{2}$. This translates into a total cost of $\$ 294 \mathrm{~K}$.

The model was then run in each of the different climate zones using eQUEST. The results are listed in Tables 89-103 and shown in Figures 57-66. 
Table 89. Bldg. 3419, savings and payback summary, Climate Zone 1A (Miami, FL).

\begin{tabular}{|l|c|c|c|c|c|}
\hline EEM & $\begin{array}{c}\text { Electrical } \\
\text { Savings } \\
(\mathbf{k W h} / \mathbf{y r})\end{array}$ & $\begin{array}{c}\text { Thermal } \\
\text { Savings } \\
(\text { Mil. Btu/yr) }\end{array}$ & $\begin{array}{c}\text { Annual Cost } \\
\text { Savings }\end{array}$ & $\begin{array}{c}\text { Implementation } \\
\text { Costs }\end{array}$ & $\begin{array}{c}\text { Payback } \\
\text { Period (yrs) }\end{array}$ \\
\hline Reduce Infiltration & 93,499 & 381 & $\$ 11,744$ & $\$ 4,843.59$ & 0.4 \\
\hline Lighting Controls & 14,028 & 0 & $\$ 1,317$ & $\$ 35,848.00$ & 27.2 \\
\hline Replacement of Mechanical Equipment & 82 & 348 & $\$ 2,715$ & $\$ 25,125.00$ & 9.3 \\
\hline PV Cells & 122,841 & 0 & $\$ 11,535$ & $\$ 294,000.00$ & 25.5 \\
\hline Replace Mechanical Equipment Controls & 503,185 & 1,049 & $\$ 55,410$ & $\$ 26,460.00$ & 0.5 \\
\hline Total & 733,635 & 1,778 & $\$ 82,721$ & $\$ 5,292.00$ & 0.1 \\
\hline
\end{tabular}

Table 90. Bldg. 3419, savings and payback summary, Climate Zone 2A (Houston, TX).

\begin{tabular}{|l|c|c|c|c|c|}
\hline EEM & $\begin{array}{c}\text { Electrical } \\
\text { Savings } \\
(\mathbf{k W h / y r})\end{array}$ & $\begin{array}{c}\text { Thermal } \\
\text { Savings } \\
(\text { Mil. Btu/yr) }\end{array}$ & $\begin{array}{c}\text { Annual Cost } \\
\text { Savings }\end{array}$ & $\begin{array}{c}\text { Implementation } \\
\text { Costs }\end{array}$ & $\begin{array}{c}\text { Payback } \\
\text { Period (yrs) }\end{array}$ \\
\hline Reduce Infiltration & 188,794 & 1,264 & $\$ 27,562$ & $\$ 4,844$ & 0.2 \\
\hline Lighting Controls & 14,028 & 0 & $\$ 1,317$ & $\$ 35,848$ & 27.2 \\
\hline Replacement of Mechanical Equipment & 71 & 564 & $\$ 4,395$ & $\$ 25,125$ & 5.7 \\
\hline PV Cells & 112,468 & 0 & $\$ 10,561$ & $\$ 294,000$ & 27.8 \\
\hline Replace Mechanical Equipment Controls & 451,867 & 1,285 & $\$ 52,428$ & $\$ 26,460$ & 0.5 \\
\hline Total & 767,228 & 3,113 & $\$ 96,262$ & 386,277 & 4.0 \\
\hline
\end{tabular}

Table 91. Bldg. 3419, savings and payback summary, Climate Zone 2B (Phoenix, AZ).

\begin{tabular}{|l|c|c|c|c|c|}
\hline EEM & $\begin{array}{c}\text { Electrical } \\
\text { Savings } \\
(\mathrm{kWh} / \mathrm{yr})\end{array}$ & $\begin{array}{c}\text { Thermal } \\
\text { Savings } \\
(\text { Mil. Btu/yr) }\end{array}$ & $\begin{array}{c}\text { Annual Cost } \\
\text { Savings }\end{array}$ & $\begin{array}{c}\text { Implementation } \\
\text { Costs }\end{array}$ & $\begin{array}{c}\text { Payback } \\
\text { Period (yrs) }\end{array}$ \\
\hline Reduce Infiltration & 173,421 & 1,184 & $\$ 25,496$ & $\$ 4,844$ & 0.2 \\
\hline Lighting Controls & 14,028 & 0 & $\$ 1,317$ & $\$ 35,848$ & 27.2 \\
\hline Replacement of Mechanical Equipment & 61 & 563 & $\$ 4,386$ & $\$ 25,125$ & 5.7 \\
\hline PV Cells & 145,187 & 0 & $\$ 13,633$ & $\$ 294,000$ & 21.6 \\
\hline Replace Mechanical Equipment Controls & 449,834 & 1,523 & $\$ 54,088$ & $\$ 26,460$ & 0.5 \\
\hline Total & 782,531 & 3,270 & $\$ 98,920$ & 386,277 & 3.9 \\
\hline
\end{tabular}

Table 92. Bldg. 3419, savings and payback summary, Climate Zone 3A (Memphis, TN).

\begin{tabular}{|l|r|r|r|r|r|}
\hline EEM & $\begin{array}{c}\text { Electrical } \\
\text { Savings } \\
(\mathrm{kWh} / \mathrm{yr})\end{array}$ & $\begin{array}{c}\text { Thermal } \\
\text { Savings } \\
(\text { Mil. Btu/yr) }\end{array}$ & $\begin{array}{c}\text { Annual Cost } \\
\text { Savings }\end{array}$ & $\begin{array}{c}\text { Implementation } \\
\text { Costs }\end{array}$ & $\begin{array}{c}\text { Payback } \\
\text { Period (yrs) }\end{array}$ \\
\hline Reduce Infiltration & 217,750 & 1,801 & $\$ 34,459$ & $\$ 4,844$ & 0.1 \\
\hline Lighting Controls & 14,028 & 0 & $\$ 1,317$ & $\$ 35,848$ & 27.2 \\
\hline Replacement of Mechanical Equipment & 55 & 710 & $\$ 5,529$ & $\$ 25,125$ & 4.5 \\
\hline PV Cells & 121,886 & 0 & $\$ 11,445$ & $\$ 294,000$ & 25.7 \\
\hline Replace Mechanical Equipment Controls & 441,338 & 1,600 & $\$ 53,890$ & $\$ 26,460$ & 0.5 \\
\hline Total & 795,057 & 4,111 & $\$ 106,639$ & 386,277 & 3.6 \\
\hline
\end{tabular}


Table 93. Bldg. 3419, savings and payback summary, Climate Zone 3B (EI Paso, TX).

\begin{tabular}{|c|c|c|c|c|c|}
\hline EEM & $\begin{array}{l}\text { Electrical } \\
\text { Savings } \\
\text { (kWh/yr) }\end{array}$ & $\begin{array}{c}\text { Thermal } \\
\text { Savings } \\
\text { (Mil. Btu/yr) }\end{array}$ & $\begin{array}{c}\text { Annual Cost } \\
\text { Savings }\end{array}$ & $\begin{array}{l}\text { Implementation } \\
\text { Costs }\end{array}$ & $\begin{array}{c}\text { Payback } \\
\text { Period (yrs) }\end{array}$ \\
\hline Reduce Infiltration & 101,975 & 1,003 & $\$ 17,379$ & $\$ 4,844$ & 0.3 \\
\hline Lighting Controls & 14,028 & 0 & $\$ 1,317$ & $\$ 35,848$ & 27.2 \\
\hline Replacement of Mechanical Equipment & 41 & 536 & $\$ 4,174$ & $\$ 25,125$ & 6.0 \\
\hline PV Cells & 148,976 & 0 & $\$ 13,989$ & $\$ 294,000$ & 21.0 \\
\hline Replace Mechanical Equipment Controls & 352,514 & 1,234 & $\$ 42,702$ & $\$ 26,460$ & 0.6 \\
\hline Total & 617,534 & 2,773 & $\$ 79,560$ & 386,277 & 4.9 \\
\hline
\end{tabular}

Table 94. Bldg. 3419, savings and payback summary, Climate Zone 3C (San Francisco, CA).

\begin{tabular}{|l|c|c|c|c|c|}
\hline EEM & $\begin{array}{c}\text { Electrical } \\
\text { Savings } \\
(\mathbf{k W h / y r})\end{array}$ & $\begin{array}{c}\text { Thermal } \\
\text { Savings } \\
(\text { Mil. Btu/yr) }\end{array}$ & $\begin{array}{c}\text { Annual Cost } \\
\text { Savings }\end{array}$ & $\begin{array}{c}\text { Implementation } \\
\text { Costs }\end{array}$ & $\begin{array}{c}\text { Payback } \\
\text { Period (yrs) }\end{array}$ \\
\hline Reduce Infiltration & 38,060 & 1,045 & $\$ 11,704$ & $\$ 4,844$ & 0.4 \\
\hline Lighting Controls & 14,028 & 0 & $\$ 1,317$ & $\$ 35,848$ & 27.2 \\
\hline Replacement of Mechanical Equipment & $-25,310$ & 592 & $\$ 2,229$ & $\$ 25,125$ & 11.3 \\
\hline PV Cells & 130,581 & 0 & $\$ 12,262$ & $\$ 294,000$ & 24.0 \\
\hline Replace Mechanical Equipment Controls & 267,781 & 1,240 & $\$ 34,792$ & $\$ 26,460$ & 0.8 \\
\hline Total & 425,140 & 2,877 & $\$ 62,304$ & 386,277 & 6.2 \\
\hline
\end{tabular}

Table 95. Bldg. 3419, savings and payback summary, Climate Zone 4A (Baltimore, MD).

\begin{tabular}{|l|c|c|c|c|c|}
\hline EEM & $\begin{array}{c}\text { Electrical } \\
\text { Savings } \\
(\mathrm{kWh} / \mathrm{yr})\end{array}$ & $\begin{array}{c}\text { Thermal } \\
\text { Savings } \\
(\text { Mil. Btu/yr) }\end{array}$ & $\begin{array}{c}\text { Annual Cost } \\
\text { Savings }\end{array}$ & $\begin{array}{c}\text { Implementation } \\
\text { Costs }\end{array}$ & $\begin{array}{c}\text { Payback } \\
\text { Period (yrs) }\end{array}$ \\
\hline Reduce Infiltration & 227,166 & 2,340 & $\$ 39,536$ & $\$ 4,844$ & 0.1 \\
\hline Lighting Controls & 14,028 & 0 & $\$ 1,317$ & $\$ 35,848$ & 27.2 \\
\hline Replacement of Mechanical Equipment & 41 & 876 & $\$ 6,819$ & $\$ 25,125$ & 3.7 \\
\hline PV Cells & 111,082 & 0 & $\$ 10,431$ & $\$ 294,000$ & 28.2 \\
\hline Replace Mechanical Equipment Controls & 418,263 & 1,963 & $\$ 54,547$ & $\$ 26,460$ & 0.5 \\
\hline Total & 770,580 & 5,179 & $\$ 112,650$ & 386,277 & 3.4 \\
\hline
\end{tabular}

Table 96. Bldg. 3419, savings and payback summary, Climate Zone 4B (Albuquerque, NM).

\begin{tabular}{|l|c|c|c|c|c|}
\hline EEM & $\begin{array}{c}\text { Electrical } \\
\text { Savings } \\
(\mathbf{k W h / y r})\end{array}$ & $\begin{array}{c}\text { Thermal } \\
\text { Savings } \\
(\text { Mil. Btu/yr) }\end{array}$ & $\begin{array}{c}\text { Annual Cost } \\
\text { Savings }\end{array}$ & $\begin{array}{c}\text { Implementation } \\
\text { Costs }\end{array}$ & $\begin{array}{c}\text { Payback } \\
\text { Period (yrs) }\end{array}$ \\
\hline Reduce Infiltration & 98,342 & 1,260 & $\$ 19,037$ & $\$ 4,844$ & 0.3 \\
\hline Lighting Controls & 14,028 & 0 & $\$ 1,317$ & $\$ 35,848$ & 27.2 \\
\hline Replacement of Mechanical Equipment & 29 & 644 & $\$ 5,013$ & $\$ 25,125$ & 5.0 \\
\hline PV Cells & 149,661 & 0 & $\$ 14,053$ & $\$ 294,000$ & 20.9 \\
\hline Replace Mechanical Equipment Controls & 313,795 & 1,329 & $\$ 39,805$ & $\$ 26,460$ & 0.7 \\
\hline Total & 575,855 & 3,233 & $\$ 79,226$ & 386,277 & 4.9 \\
\hline
\end{tabular}


Table 97. Bldg. 3419, savings and payback summary, Climate Zone 4C (Seattle, WA).

\begin{tabular}{|l|c|c|c|c|c|}
\hline EEM & $\begin{array}{c}\text { Electrical } \\
\text { Savings } \\
(\mathbf{k W h} / \mathbf{y r})\end{array}$ & $\begin{array}{c}\text { Thermal } \\
\text { Savings } \\
(\text { Mil. Btu/yr) }\end{array}$ & $\begin{array}{c}\text { Annual Cost } \\
\text { Savings }\end{array}$ & $\begin{array}{c}\text { Implementation } \\
\text { Costs }\end{array}$ & $\begin{array}{c}\text { Payback } \\
\text { Period (yrs) }\end{array}$ \\
\hline Reduce Infiltration & 66,053 & 1,386 & $\$ 16,985$ & $\$ 4,844$ & 0.3 \\
\hline Lighting Controls & 14,028 & 0 & $\$ 1,317$ & $\$ 35,848$ & 27.2 \\
\hline Replacement of Mechanical Equipment & 17 & 711 & $\$ 5,533$ & $\$ 25,125$ & 4.5 \\
\hline PV Cells & 91,500 & 0 & $\$ 8,592$ & $\$ 294,000$ & 34.2 \\
\hline Replace Mechanical Equipment Controls & 262,232 & 1,294 & $\$ 34,691$ & $\$ 26,460$ & 0.8 \\
\hline Total & 433,830 & 3,391 & $\$ 67,119$ & 386,277 & 5.8 \\
\hline
\end{tabular}

Table 98. Bldg. 3419, savings and payback summary, Climate Zone 5A (Chicago, IL).

\begin{tabular}{|l|c|c|c|c|c|}
\hline EEM & $\begin{array}{c}\text { Electrical } \\
\text { Savings } \\
(\mathbf{k W h} / \mathbf{y r})\end{array}$ & $\begin{array}{c}\text { Thermal } \\
\text { Savings } \\
(\text { Mil. Btu/yr) }\end{array}$ & $\begin{array}{c}\text { Annual Cost } \\
\text { Savings }\end{array}$ & $\begin{array}{c}\text { Implementation } \\
\text { Costs }\end{array}$ & $\begin{array}{c}\text { Payback } \\
\text { Period (yrs) }\end{array}$ \\
\hline Reduce Infiltration & 132,235 & 3,132 & $\$ 36,784$ & $\$ 4,844$ & 0.1 \\
\hline Lighting Controls & 14,028 & 0 & $\$ 1,317$ & $\$ 35,848$ & 27.2 \\
\hline Replacement of Mechanical Equipment & 29 & 1,130 & $\$ 8,794$ & $\$ 25,125$ & 2.9 \\
\hline PV Cells & 107,490 & 0 & $\$ 10,093$ & $\$ 294,000$ & 29.1 \\
\hline Replace Mechanical Equipment Controls & 370,310 & 2,428 & $\$ 53,662$ & $\$ 26,460$ & 0.5 \\
\hline Total & 624,092 & 6,690 & $\$ 110,650$ & 386,277 & 3.5 \\
\hline
\end{tabular}

Table 99. Bldg. 3419, savings and payback summary, Climate Zone 5B (Colorado Springs, C0).

\begin{tabular}{|l|c|c|c|c|c|}
\hline EEM & $\begin{array}{c}\text { Electrical } \\
\text { Savings } \\
(\mathrm{kWh} / \mathrm{yr})\end{array}$ & $\begin{array}{c}\text { Thermal } \\
\text { Savings } \\
(\text { Mil. Btu/yr) }\end{array}$ & $\begin{array}{c}\text { Annual Cost } \\
\text { Savings }\end{array}$ & $\begin{array}{c}\text { Implementation } \\
\text { Costs }\end{array}$ & $\begin{array}{c}\text { Payback } \\
\text { Period (yrs) }\end{array}$ \\
\hline Reduce Infiltration & 156,870 & 2,196 & $\$ 31,815$ & $\$ 4,844$ & 0.2 \\
\hline Lighting Controls & 14,028 & 0 & $\$ 1,317$ & $\$ 35,848$ & 27.2 \\
\hline Replacement of Mechanical Equipment & 21 & 866 & $\$ 6,739$ & $\$ 25,125$ & 3.7 \\
\hline PV Cells & 133,221 & 0 & $\$ 12,509$ & $\$ 294,000$ & 23.5 \\
\hline Replace Mechanical Equipment Controls & 355,341 & 1,962 & $\$ 48,631$ & $\$ 26,460$ & 0.5 \\
\hline Total & 659,481 & 5,024 & $\$ 101,012$ & 386,277 & 3.8 \\
\hline
\end{tabular}

Table 100. Bldg. 3419, savings and payback summary, Climate Zone 6A (Burlington, VT).

\begin{tabular}{|l|r|r|r|r|r|}
\hline \multicolumn{1}{|c|}{ EEM } & $\begin{array}{c}\text { Electrical } \\
\text { Savings } \\
(\mathrm{kWh} / \mathrm{yr})\end{array}$ & $\begin{array}{c}\text { Thermal } \\
\text { Savings } \\
(\text { Mil. Btu/yr) }\end{array}$ & $\begin{array}{c}\text { Annual Cost } \\
\text { Savings }\end{array}$ & $\begin{array}{c}\text { Implementation } \\
\text { Costs }\end{array}$ & $\begin{array}{c}\text { Payback } \\
\text { Period (yrs) }\end{array}$ \\
\hline Reduce Infiltration & 158,839 & 3,441 & $\$ 41,686$ & $\$ 4,844$ & 0.1 \\
\hline Lighting Controls & 14,028 & 0 & $\$ 1,317$ & $\$ 35,848$ & 27.2 \\
\hline Replacement of Mechanical Equipment & 26 & 1,240 & $\$ 9,650$ & $\$ 25,125$ & 2.6 \\
\hline PV Cells & 105,512 & 0 & $\$ 9,908$ & $\$ 294,000$ & 29.7 \\
\hline Replace Mechanical Equipment Controls & 368,124 & 2,628 & $\$ 55,013$ & $\$ 26,460$ & 0.5 \\
\hline Total & 646,529 & 7,309 & $\$ 117,573$ & 386,277 & 3.3 \\
\hline
\end{tabular}


Table 101. Bldg. 3419, savings and payback summary, Climate Zone 6B (Helena, MT).

\begin{tabular}{|c|c|c|c|c|c|}
\hline EEM & $\begin{array}{l}\text { Electrical } \\
\text { Savings } \\
\text { (kWh/yr) }\end{array}$ & $\begin{array}{c}\text { Thermal } \\
\text { Savings } \\
\text { (Mil. Btu/yr) }\end{array}$ & $\begin{array}{c}\text { Annual Cost } \\
\text { Savings }\end{array}$ & $\begin{array}{l}\text { Implementation } \\
\text { Costs }\end{array}$ & $\begin{array}{c}\text { Payback } \\
\text { Period (yrs) }\end{array}$ \\
\hline Reduce Infiltration & 127,873 & 3,194 & $\$ 36,857$ & $\$ 4,844$ & 0.1 \\
\hline Lighting Controls & 14,028 & 0 & $\$ 1,317$ & $\$ 35,848$ & 27.2 \\
\hline Replacement of Mechanical Equipment & 18 & 1,167 & $\$ 9,081$ & $\$ 25,125$ & 2.8 \\
\hline PV Cells & 111,581 & 0 & $\$ 10,477$ & $\$ 294,000$ & 28.1 \\
\hline Replace Mechanical Equipment Controls & 340,017 & 2,519 & $\$ 51,525$ & $\$ 26,460$ & 0.5 \\
\hline Total & 593,517 & 6,880 & $\$ 109,258$ & 386,277 & 3.5 \\
\hline
\end{tabular}

Table 102. BIdg. 3419, savings and payback summary, Climate Zone 7A (Duluth, MN).

\begin{tabular}{|l|c|c|c|c|c|}
\hline EEM & $\begin{array}{c}\text { Electrical } \\
\text { Savings } \\
(\mathbf{k W h} / \mathbf{y r})\end{array}$ & $\begin{array}{c}\text { Thermal } \\
\text { Savings } \\
(\text { Mil. Btu/yr) }\end{array}$ & $\begin{array}{c}\text { Annual Cost } \\
\text { Savings }\end{array}$ & $\begin{array}{c}\text { Implementation } \\
\text { Costs }\end{array}$ & $\begin{array}{c}\text { Payback } \\
\text { Period (yrs) }\end{array}$ \\
\hline Reduce Infiltration & 23,246 & 4,029 & $\$ 33,528$ & $\$ 4,844$ & 0.1 \\
\hline Lighting Controls & 14,028 & 0 & $\$ 1,317$ & $\$ 35,848$ & 27.2 \\
\hline Replacement of Mechanical Equipment & 17 & 1,470 & $\$ 11,438$ & $\$ 25,125$ & 2.2 \\
\hline PV Cells & 107,739 & 0 & $\$ 10,117$ & $\$ 294,000$ & 29.1 \\
\hline Replace Mechanical Equipment Controls & 331,985 & 3,410 & $\$ 57,703$ & $\$ 26,460$ & 0.5 \\
\hline Total & 477,015 & 8,909 & $\$ 114,104$ & 386,277 & 3.4 \\
\hline
\end{tabular}

Table 103. Bldg. 3419, savings and payback summary, Climate Zone 8A (Fairbanks, AK).

\begin{tabular}{|l|c|c|c|c|c|}
\hline EEM & $\begin{array}{c}\text { Electrical } \\
\text { Savings } \\
(\mathbf{k W h} / \mathbf{y r})\end{array}$ & $\begin{array}{c}\text { Thermal } \\
\text { Savings } \\
(\text { Mil. Btu/yr) }\end{array}$ & $\begin{array}{c}\text { Annual Cost } \\
\text { Savings }\end{array}$ & $\begin{array}{c}\text { Implementation } \\
\text { Costs }\end{array}$ & $\begin{array}{c}\text { Payback } \\
\text { Period (yrs) }\end{array}$ \\
\hline Reduce Infiltration & 8,115 & 6,353 & $\$ 50,188$ & $\$ 4,844$ & 0.1 \\
\hline Lighting Controls & 14,028 & 0 & $\$ 1,317$ & $\$ 35,848$ & 27.2 \\
\hline Replacement of Mechanical Equipment & 12 & 2,174 & $\$ 16,915$ & $\$ 25,125$ & 1.5 \\
\hline PV Cells & 77,609 & 0 & $\$ 7,287$ & $\$ 294,000$ & 40.3 \\
\hline Replace Mechanical Equipment Controls & 297,308 & 5,668 & $\$ 72,014$ & $\$ 26,460$ & 0.4 \\
\hline Total & 397,072 & 14,195 & $\$ 147,722$ & 386,277 & 2.6 \\
\hline
\end{tabular}

Figure 57. Bldg. 3419, annual cost savings resulting from EEM “Reduce Infiltration," by climate zone.

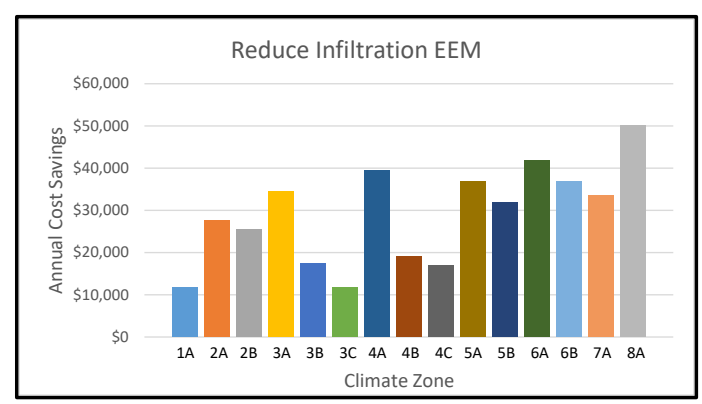

Figure 58. Bldg. 3419 , simple payback resulting from EEM “Reduce Infiltration," by climate zone.

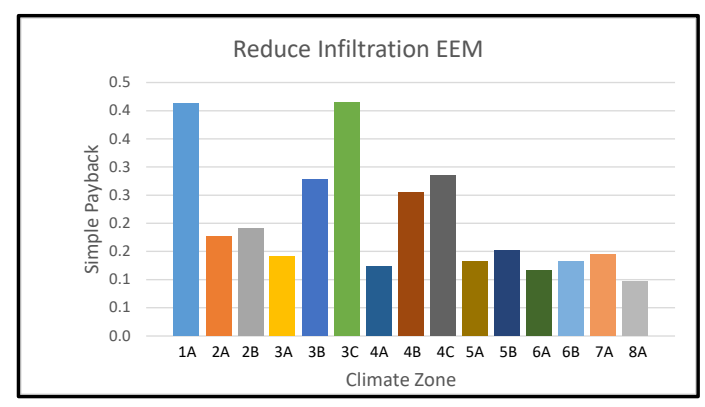


Figure 59. Bldg. 3419, annual cost savings resulting from EEM “Lighting Controls," by climate zone.

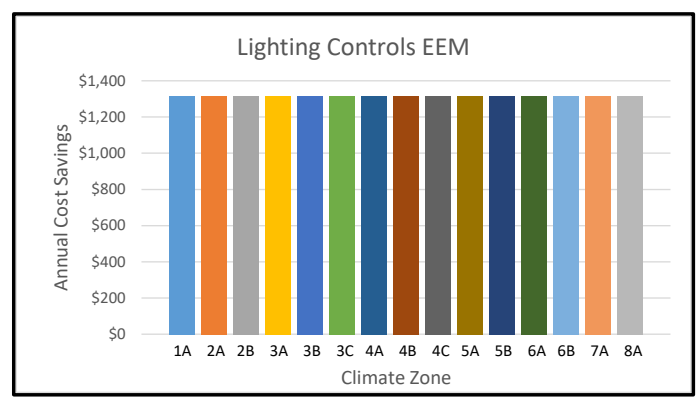

Figure 61. Bldg. 3419, annual cost savings resulting from EEM “PV Cells," by climate zone.

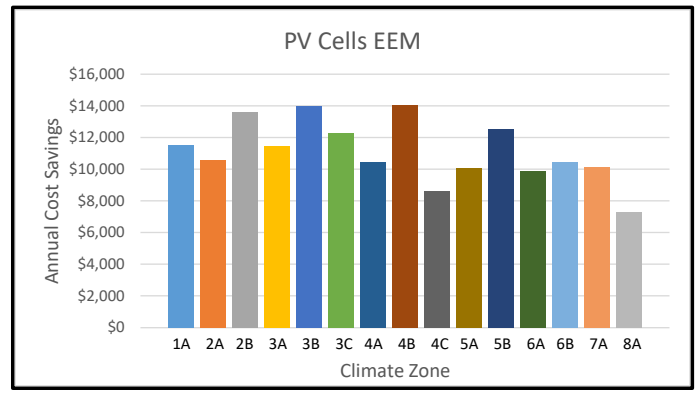

Figure 63. Bldg. 3419, annual cost savings resulting from EEM “Replace Mechanical Equipment EEM," by climate zone.

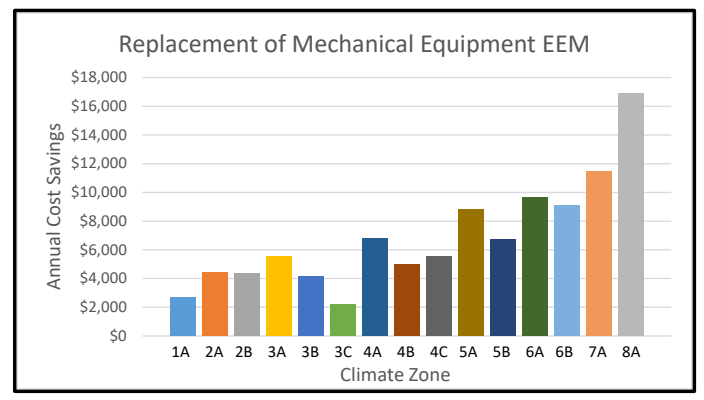

Figure 60 . Bldg. 3419 , simple payback resulting from EEM “Lighting Controls," by climate zone.

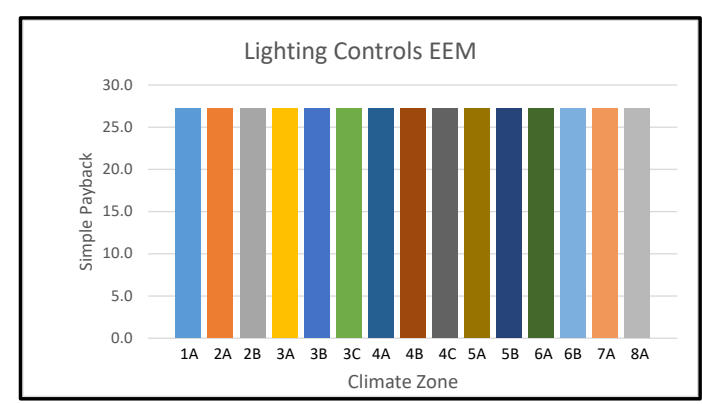

Figure 62. Bldg. 3419, simple payback resulting from EEM “PV Cells," by climate zone.

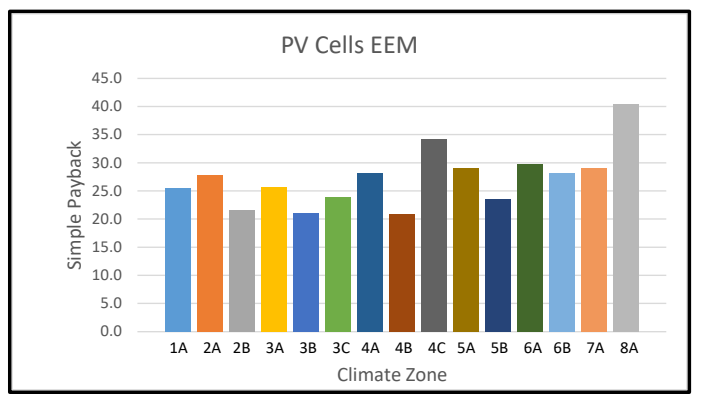

Figure 64. Bldg. 3419, simple payback resulting from EEM “Replace Mechanical Equipment EEM," by climate zone.

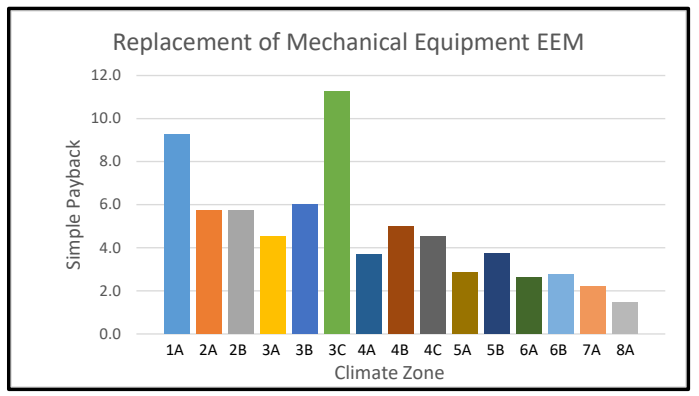


Figure 65 . Bldg. 3419 , annual cost savings resulting from EEM "Replace Mechanical Equipment Controls EEM," by climate zone.

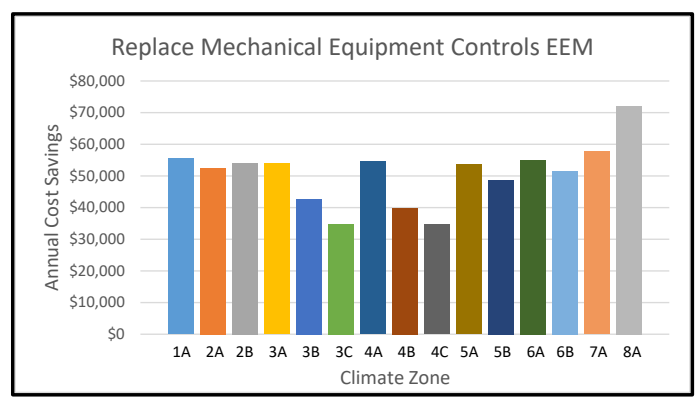

Figure 66. Bldg. 3419 , simple payback resulting from EEM "Replace Mechanical Equipment Controls EEM," by climate zone.

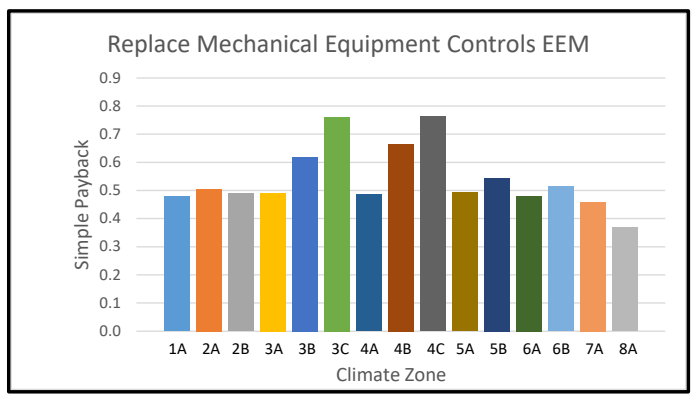




\section{Fort Bliss and Buildings Modeled}

While this project was focused on the buildings at Fort Sill, three buildings that were modeled as part of a different study were revisited.

\subsection{Buildings modeled}

\subsubsection{Bldg. 1}

Figure 67. Bldg. 1, Fort Bliss.

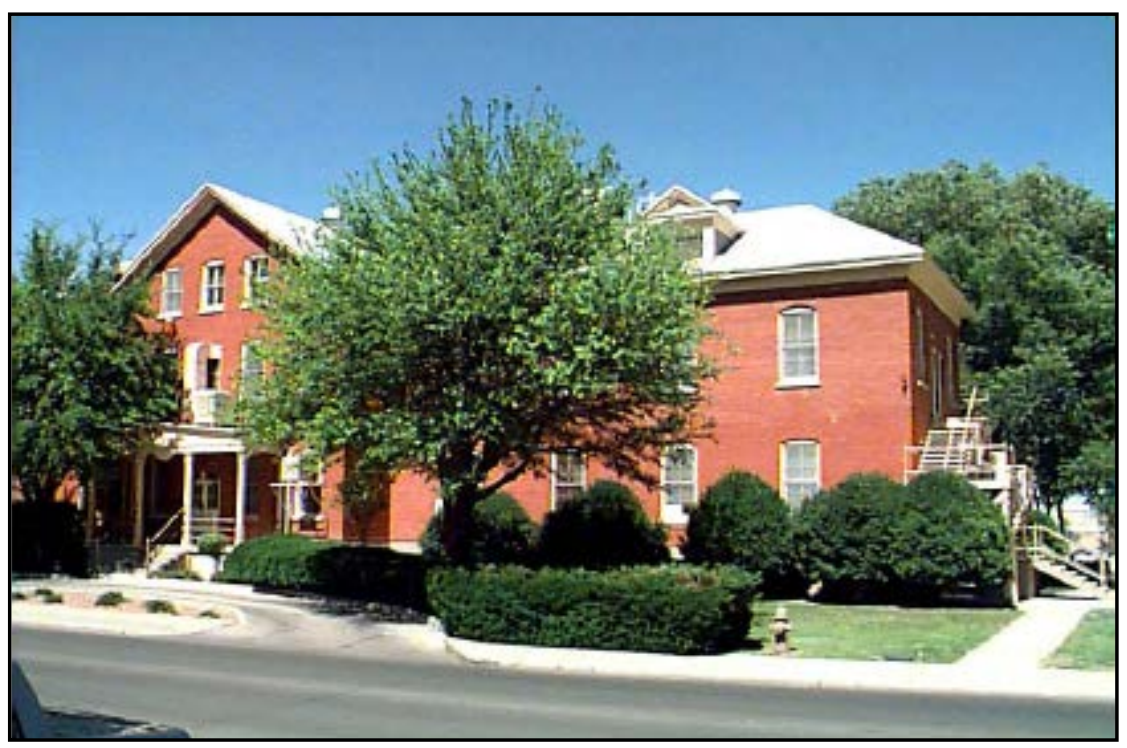

Table 104. Fort Bliss, Bldg. 1 details.

\begin{tabular}{|l|l|}
\hline Parameter & Measure \\
\hline Year Built & 1904 \\
\hline Square Footage $\mathrm{ft}^{2}$ & 30,340 \\
\hline \# of Stories & $3+$ basement \\
\hline Use Type & Administrative \\
\hline Envelope & Wood Frame, clay tiles \\
\hline Roof & R-13 batt, no radiant barrier \\
\hline Construction & \multicolumn{2}{|l}{} \\
\hline Insulation type and thickness & Triple brick masonry \\
\hline Wall & None \\
\hline Construction & \\
\hline Insulation type/thickness/location & \\
\hline Floor/Basement &
\end{tabular}




\begin{tabular}{|c|c|}
\hline Parameter & Measure \\
\hline Construction & Basement \\
\hline Insulation type/thickness/location & None \\
\hline \multicolumn{2}{|l|}{ Windows } \\
\hline Glazing/Frame/Features & Single Pane, Wood Frame, Clear \\
\hline Gross $\%$ of wall area (Overall) & $15.9 \%$ \\
\hline \multicolumn{2}{|l|}{ Occupancy } \\
\hline Use type & Administrative \\
\hline Hours & 0700-1800 M-Sa \\
\hline Average \# of Occupants (if available) & N/A \\
\hline \multicolumn{2}{|l|}{ HVAC } \\
\hline Heating System & Forced Air \\
\hline Cooling System & Direct Expansion (DX) Coils \\
\hline Domestic Hot Water System & Natural gas fired, 39 gal tank \\
\hline HVAC Controls & Thermostat \\
\hline \multicolumn{2}{|l|}{ Lighting and plug loads } \\
\hline Primary Lighting Type/Fixture & Various \\
\hline Lighting Usage & On during occupied/off during unoccupied hours \\
\hline Lighting Controls? & Switches \\
\hline
\end{tabular}

\subsubsection{Bldg. 115}

Figure 68. Bldg. 115, administrative building.

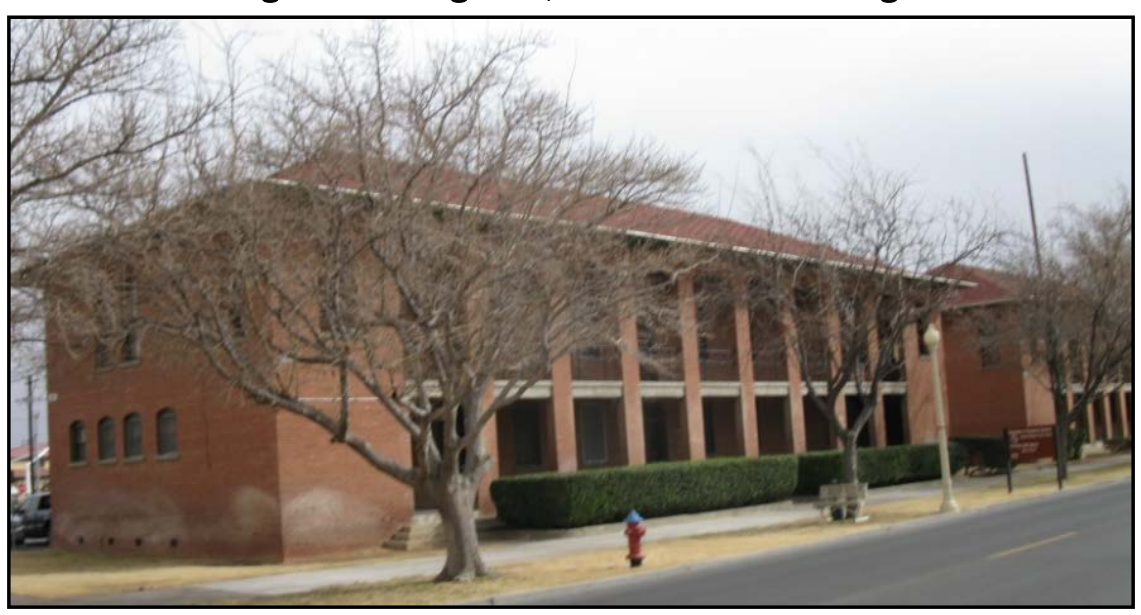


Table 105. Bldg. 115 Fort Bliss details.

\begin{tabular}{|c|c|}
\hline Parameter & Measure \\
\hline Year Built & 1915 \\
\hline Square Footage $\mathrm{ft}^{2}$ & 6,300 \\
\hline \# of Stories & $2+1 / 2$ basement \\
\hline Use Type & Administrative \\
\hline \multicolumn{2}{|l|}{ Envelope } \\
\hline \multicolumn{2}{|l|}{ Roof } \\
\hline Construction & Wood Frame, clay tiles \\
\hline Insulation type and thickness & None \\
\hline \multicolumn{2}{|l|}{ Wall } \\
\hline Construction & Concrete masonry unit (12 in.) \\
\hline Insulation type/thickness/location & None \\
\hline \multicolumn{2}{|l|}{ Floor/Basement } \\
\hline Construction & Crawlspace/basement \\
\hline Insulation type/thickness/location & None \\
\hline \multicolumn{2}{|l|}{ Windows } \\
\hline Glazing/Frame/Features & Single Pane, Wood Frame, Clear \\
\hline Gross \% of wall area (Overall) & $15.9 \%$ \\
\hline \multicolumn{2}{|l|}{ Occupancy } \\
\hline Use type & Administrative \\
\hline Hours & $\begin{array}{l}24 \text { hrs daily on } 1^{\text {st }} \text { floor } \\
0700-1700 \text { on } 2^{\text {nd }} \text { floor }\end{array}$ \\
\hline Average \# of Occupants (if available) & N/A \\
\hline \multicolumn{2}{|l|}{ HVAC } \\
\hline Heating System & Air source heat pumps \\
\hline Cooling System & Air source heat pumps \\
\hline Domestic Hot Water System & Natural gas fired, 16 gal tank \\
\hline HVAC Controls & DDC \\
\hline \multicolumn{2}{|l|}{ Lighting and plug loads } \\
\hline Primary Lighting Type/Fixture & Fluorescent T8 \\
\hline Lighting Usage & On during occupied/off during unoccupied hours \\
\hline Lighting Controls & Switches \\
\hline
\end{tabular}




\subsubsection{Bldg. 1103}

Figure 69. Bldg. 1103, general purpose warehouse.

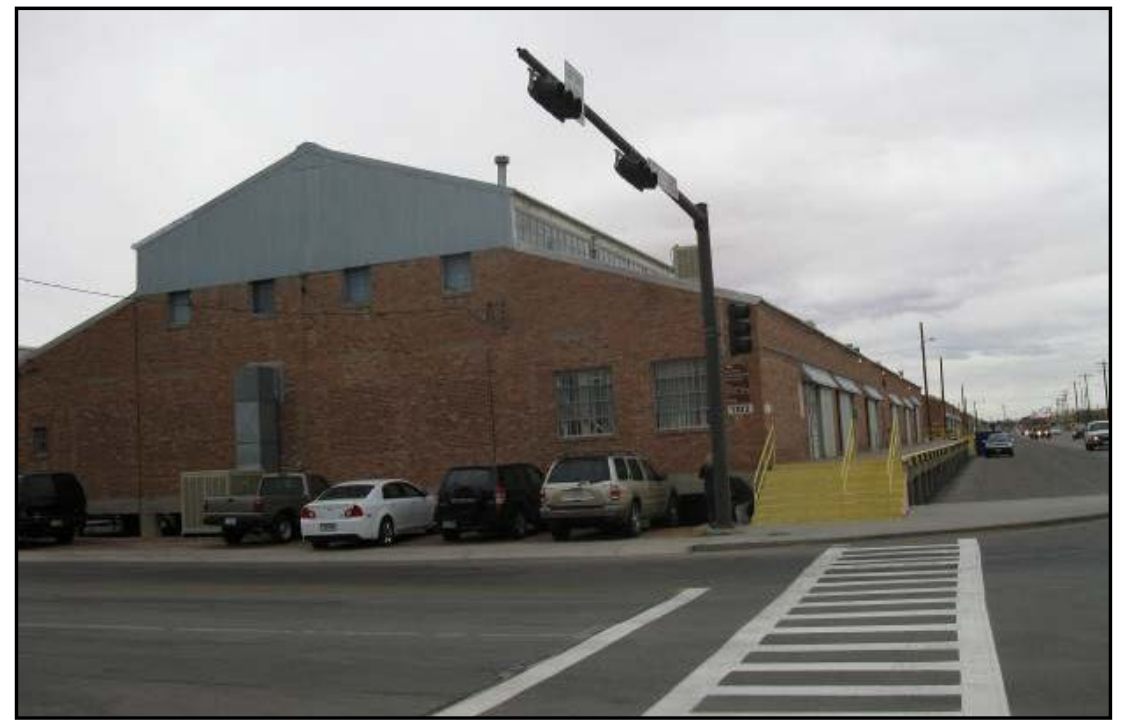

Table 106. Fort Bliss Bldg. 1103, details.

\begin{tabular}{|c|c|}
\hline Parameter & Measure \\
\hline Year Built & 1921 \\
\hline Square Footage $\mathrm{ft}^{2}$ & 16,000 \\
\hline \# of Stories & $1+$ \\
\hline Use Type & Warehouse \\
\hline \multicolumn{2}{|l|}{ Envelope } \\
\hline \multicolumn{2}{|l|}{ Roof } \\
\hline Construction & Wood Frame (24 in. o.c.), galvanized steel finish \\
\hline Insulation type and thickness & R-11 batt, no radiant barrier \\
\hline \multicolumn{2}{|l|}{ Wall } \\
\hline Construction & Concrete masonry unit (12 in.) \\
\hline Insulation type/thickness/location & None \\
\hline \multicolumn{2}{|l|}{ Floor/Basement } \\
\hline Construction & 8 in. concrete floor $5 \mathrm{ft}$ above grade \\
\hline Insulation type/thickness/location & None \\
\hline \multicolumn{2}{|l|}{ Windows } \\
\hline Glazing/Frame/Features & $\begin{array}{l}\text { Single Pane, Aluminum Frame, Clear } \\
\text { Double Pane, Aluminum Frame, Tint }\end{array}$ \\
\hline Gross \% of wall area (Overall) & $11.4 \%$ \\
\hline
\end{tabular}




\begin{tabular}{|l|l|}
\hline Parameter & Measure \\
\hline Use type & Warehouse \\
\hline Hours & 0800-1700 M-F \\
\hline Average \# of Occupants (if available) & N/A \\
\hline HVAC & Forced Air \\
\hline Heating System & Evaporative Coolers \\
\hline Cooling System & Natural gas fired, 5 gal tank \\
\hline Domestic Hot Water System & Thermostat \\
\hline HVAC Controls & \multicolumn{2}{|l|}{} \\
\hline Lighting and plug loads & Fluorescent T8 \\
\hline Primary Lighting Type/Fixture & On during occupied/off during unoccupied hours \\
\hline Lighting Usage & Switches \\
\hline Lighting Controls &
\end{tabular}

\subsection{The building model results - "as is"}

\subsubsection{Bldg. 1 energy use - "as is"}

The simulated annual energy use for Bldg. 1 is 335,800 kWh/year of electricity and 900.33 MMBtu/year of gas. With 30,340 $\mathrm{ft}^{2}$ of envelope area, this equates to an EUI of $67 \mathrm{kBtu} / \mathrm{ft}^{2} / \mathrm{yr}$. The typical EUI for this building type (according to CBECS) in this climate is $87 \mathrm{kBtu} / \mathrm{ft}^{2} / \mathrm{yr}$.

\subsubsection{Bldg. 115 energy use - "as is"}

The simulated annual energy use for Bldg. 115 is 200,130 kWh/year of electricity and 7.41 MMBtu/year of gas. With 6,300 $\mathrm{ft}^{2}$ of envelope area, this equates to an EUI of $110 \mathrm{kBtu} / \mathrm{ft}^{2} / \mathrm{yr}$. The typical EUI for this building type (according to the Buildings Energy Data Book) in this climate is 47 $\mathrm{kBtu} / \mathrm{ft}^{2} / \mathrm{yr}$. This is only somewhat reliable due to representing only five total buildings. The most likely reason for the larger than usual energy use is the 24 hour per day occupancy of part of the building.

\subsubsection{Bldg. 1103 energy use - "as is"}

The simulated annual energy use for Bldg. 1103 is 77,250 kWh/year of electricity and 1,163.1 MMBtu/year of gas. With 16,000 $\mathrm{ft}^{2}$ of envelope area, this equates to an EUI of $89 \mathrm{kBtu} / \mathrm{ft}^{2} / \mathrm{yr}$. The typical EUI for this building type (according to the Buildings Energy Data Book) in this climate is $57 \mathrm{kBtu} / \mathrm{ft}^{2} / \mathrm{yr}$. 


\subsection{EEMs considered}

\subsubsection{Bldg. 1 EEM savings by climate zone}

The EEMs chosen for Bldg. 1 were those with a simple payback of less than 30 years, for the actual location of the building in El Paso, TX. These were:

- Reduce Infiltration. Building infiltration was changed from 2.00 ACH to $1.00 \mathrm{ACH}$.

- High Efficiency Lighting. The lighting power densities of the building were changed. Figure 70 shows the specifications.

- Wall Insulation. Three and a half inches of mineral/wool fiber fill insulation were added between the brick and gypsum board wall layers, where previously there was no insulation.

- Night setback of thermostat temperatures. The unoccupied cooling and heating setpoints were changed from 76 and $68^{\circ} \mathrm{F}$, to 80 and $60^{\circ} \mathrm{F}$, respectively.

Figure 70. Fort Bliss BIdg. 1, lighting details.

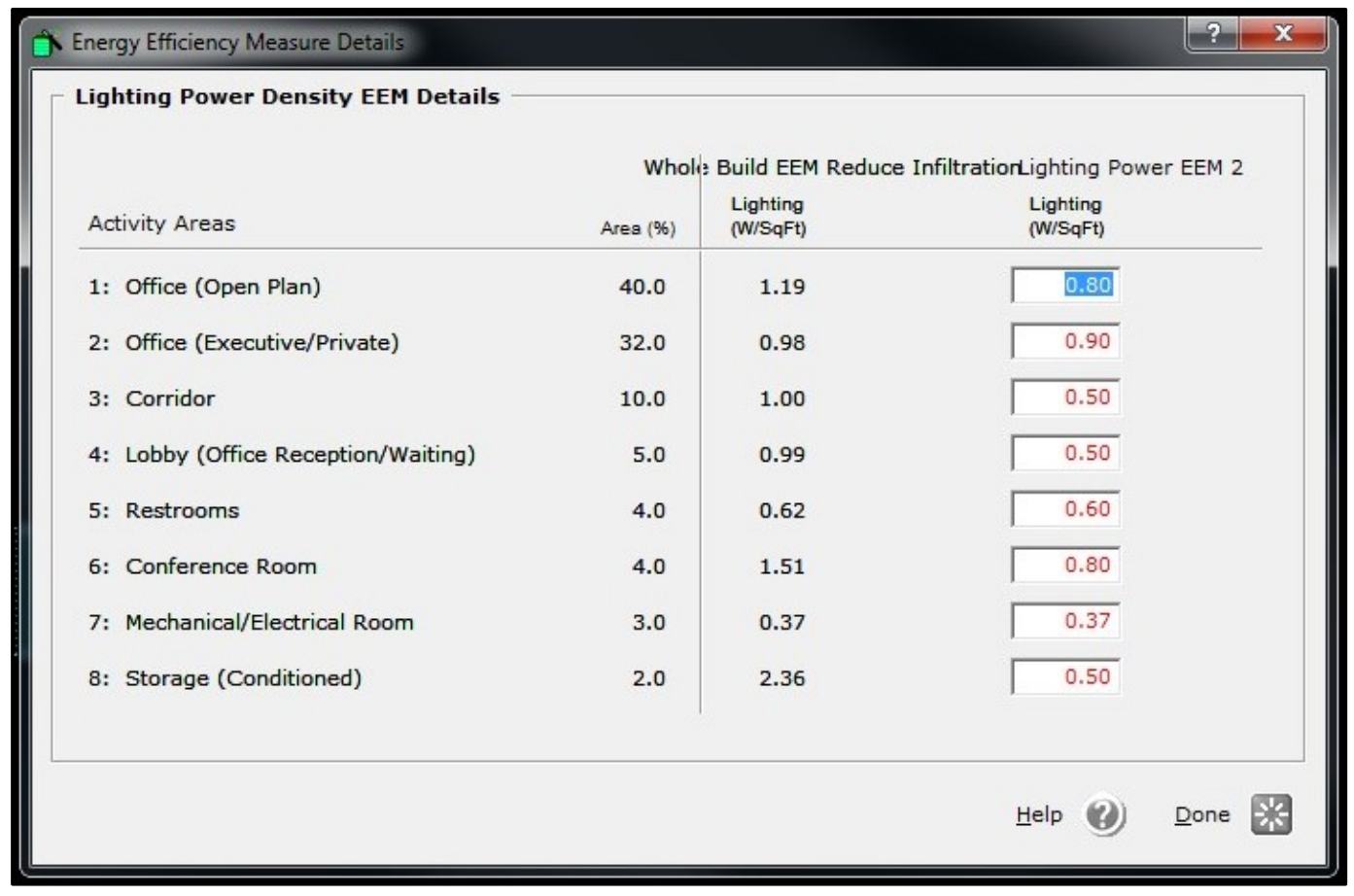

The model was then run in each of the different climate zones using eQUEST. The results are listed in Tables 107-121 and shown in Figures 71-79. 
Table 107. Bldg. 1, Fort Bliss, savings and payback summary, Climate Zone 1A (Miami, FL).

\begin{tabular}{|l|c|c|c|c|c|}
\hline EEM & $\begin{array}{c}\text { Electrical } \\
\text { Savings } \\
(\mathbf{k W h} / \mathbf{y r})\end{array}$ & $\begin{array}{c}\text { Thermal } \\
\text { Savings } \\
\text { (Mil. } \\
\text { Btu/yr) }\end{array}$ & $\begin{array}{c}\text { Annual } \\
\text { Cost } \\
\text { Savings }\end{array}$ & $\begin{array}{c}\text { Implementation } \\
\text { Costs }\end{array}$ & $\begin{array}{c}\text { Payback } \\
\text { Period (yrs) }\end{array}$ \\
\hline Reduce infiltration & 38,338 & 34 & $\$ 3,864$ & $\$ 16,406$ & 4.2 \\
\hline High efficiency lighting & 40,619 & -2 & $\$ 3,799$ & $\$ 52,807$ & 13.9 \\
\hline Wall insulation & 17,725 & -3 & $\$ 1,641$ & $\$ 13,723$ & 8.4 \\
\hline Night setback of thermostat temperatures & 22,182 & 11 & $\$ 2,168$ & $\$ 446$ & 0.2 \\
\hline Total & 118,864 & 40 & $\$ 11,473$ & $\$ 83,382$ & 7.3 \\
\hline
\end{tabular}

Table 108. Bldg. 1, Fort Bliss, savings and payback summary, Climate Zone 2A (Houston, TX).

\begin{tabular}{|l|c|c|c|c|c|}
\hline EEM & $\begin{array}{c}\text { Electrical } \\
\text { Savings } \\
(\mathrm{kWh} / \mathrm{yr})\end{array}$ & $\begin{array}{c}\text { Thermal } \\
\text { Savings } \\
\mathbf{( M i l .} \\
\text { Btu/yr) }\end{array}$ & $\begin{array}{c}\text { Annual } \\
\text { Cost } \\
\text { Savings }\end{array}$ & $\begin{array}{c}\text { Implementation } \\
\text { Costs }\end{array}$ & $\begin{array}{c}\text { Payback } \\
\text { Period } \\
\text { (yrs) }\end{array}$ \\
\hline Reduce infiltration & 29,232 & 282 & $\$ 4,939$ & $\$ 16,406$ & 3.3 \\
\hline High efficiency lighting & 39,109 & -24 & $\$ 3,486$ & $\$ 52,807$ & 15.1 \\
\hline Wall insulation & 11,957 & 59 & $\$ 1,582$ & $\$ 13,723$ & 8.7 \\
\hline Night setback of thermostat temperatures & 18,032 & 102 & $\$ 2,487$ & $\$ 446$ & 0.2 \\
\hline Total & 98,330 & 419 & $\$ 12,493$ & $\$ 83,382$ & 6.7 \\
\hline
\end{tabular}

Table 109. Bldg. 1, Fort Bliss, savings and payback summary, Climate Zone 2B (Phoenix, AZ).

\begin{tabular}{|l|c|c|c|c|c|}
\hline EEM & $\begin{array}{c}\text { Electrical } \\
\text { Savings } \\
(\mathbf{k W h} / \mathbf{y r})\end{array}$ & $\begin{array}{c}\text { Thermal } \\
\text { Savings } \\
\mathbf{( M i l .} \\
\text { Btu/yr) }\end{array}$ & $\begin{array}{c}\text { Annual } \\
\text { Cost } \\
\text { Savings }\end{array}$ & $\begin{array}{c}\text { Implementation } \\
\text { Costs }\end{array}$ & $\begin{array}{c}\text { Payback } \\
\text { Period } \\
\text { (yrs) }\end{array}$ \\
\hline Reduce infiltration & 46,640 & 230 & $\$ 6,169$ & $\$ 16,406$ & 2.7 \\
\hline High efficiency lighting & 38,932 & -18 & $\$ 3,516$ & $\$ 52,807$ & 15.0 \\
\hline Wall insulation & 17,145 & 25 & $\$ 1,804$ & $\$ 13,723$ & 7.6 \\
\hline Night setback of thermostat temperatures & 23,625 & 90 & $\$ 2,919$ & $\$ 446$ & 0.2 \\
\hline Total & 126,342 & 327 & $\$ 14,408$ & $\$ 83,382$ & 5.8 \\
\hline
\end{tabular}

Table 110. Bldg. 1, Fort Bliss, savings and payback summary, Climate Zone 3A (Memphis, TN).

\begin{tabular}{|l|c|c|c|c|c|}
\hline EEM & $\begin{array}{c}\text { Electrical } \\
\text { Savings } \\
(\mathbf{k W h} / \mathbf{y r})\end{array}$ & $\begin{array}{c}\text { Thermal } \\
\text { Savings } \\
\text { (Mil. } \\
\text { Btu/yr) }\end{array}$ & $\begin{array}{c}\text { Annual } \\
\text { Cost } \\
\text { Savings }\end{array}$ & $\begin{array}{c}\text { Implementation } \\
\text { Costs }\end{array}$ & $\begin{array}{c}\text { Payback } \\
\text { Period } \\
\text { (yrs) }\end{array}$ \\
\hline Reduce infiltration & 23,856 & 506 & $\$ 6,177$ & $\$ 16,406$ & 2.7 \\
\hline High efficiency lighting & 38,268 & -45 & $\$ 3,243$ & $\$ 52,807$ & 16.3 \\
\hline Wall insulation & 8,914 & 145 & $\$ 1,965$ & $\$ 13,723$ & 7.0 \\
\hline Night setback of thermostat temperatures & 17,678 & 169 & $\$ 2,975$ & $\$ 446$ & 0.1 \\
\hline Total & $\mathbf{8 8 , 7 1 6}$ & $\mathbf{7 7 4}$ & $\$ 14,352$ & $\$ 83,382$ & 5.8 \\
\hline
\end{tabular}


Table 111. Bldg. 1, Fort Bliss, savings and payback summary, Climate Zone 3B (El Paso, TX).

\begin{tabular}{|l|c|c|c|c|c|}
\hline EEM & $\begin{array}{c}\text { Electrical } \\
\text { Savings } \\
(\mathbf{k W h} / \mathbf{y r})\end{array}$ & $\begin{array}{c}\text { Thermal } \\
\text { Savings } \\
\text { (Mil. } \\
\text { Btu/yr) }\end{array}$ & $\begin{array}{c}\text { Annual } \\
\text { Cost } \\
\text { Savings }\end{array}$ & $\begin{array}{c}\text { Implementation } \\
\text { Costs }\end{array}$ & $\begin{array}{c}\text { Payback } \\
\text { Period } \\
\text { (yrs) }\end{array}$ \\
\hline Reduce infiltration & 18,273 & 375 & $\$ 4,633$ & $\$ 16,406$ & 3.5 \\
\hline High efficiency lighting & 37,180 & -34 & $\$ 3,227$ & $\$ 52,807$ & 16.4 \\
\hline Wall insulation & 8,348 & 74 & $\$ 1,360$ & $\$ 13,723$ & 10.1 \\
\hline Night setback of thermostat temperatures & 17,463 & 141 & $\$ 2,737$ & $\$ 446$ & 0.2 \\
\hline Total & $\mathbf{8 1 , 2 6 4}$ & 556 & $\$ 11,956$ & $\$ 83,382$ & 7.0 \\
\hline
\end{tabular}

Table 112. Bldg. 1, Fort Bliss, savings and payback summary, Climate Zone $3 \mathrm{C}$ (San Francisco, CA).

\begin{tabular}{|l|c|c|c|c|c|}
\hline EEM & $\begin{array}{c}\text { Electrical } \\
\text { Savings } \\
(\mathbf{k W h} / \mathbf{y r})\end{array}$ & $\begin{array}{c}\text { Thermal } \\
\text { Savings } \\
\mathbf{( M i l .} \\
\text { Btu/yr) }\end{array}$ & $\begin{array}{c}\text { Annual } \\
\text { Cost } \\
\text { Savings }\end{array}$ & $\begin{array}{c}\text { Implementation } \\
\text { Costs }\end{array}$ & $\begin{array}{c}\text { Payback } \\
\text { Period } \\
\text { (yrs) }\end{array}$ \\
\hline Reduce infiltration & 7,535 & 618 & $\$ 5,516$ & $\$ 16,406$ & 3.0 \\
\hline High efficiency lighting & 34,707 & -71 & $\$ 2,707$ & $\$ 52,807$ & 19.5 \\
\hline Wall insulation & $-7,155$ & 125 & $\$ 301$ & $\$ 13,723$ & 45.6 \\
\hline Night setback of thermostat temperatures & 19,512 & 265 & $\$ 3,894$ & $\$ 446$ & 0.1 \\
\hline Total & $\mathbf{5 4 , 5 9 9}$ & $\mathbf{9 3 8}$ & $\mathbf{\$ 1 2 , 4 2 4}$ & $\$ 83,382$ & 6.7 \\
\hline
\end{tabular}

Table 113. Bldg. 1, Fort Bliss, savings and payback summary, Climate Zone 4A (Baltimore, MD).

\begin{tabular}{|l|c|c|c|c|c|}
\hline EEM & $\begin{array}{c}\text { Electrical } \\
\text { Savings } \\
(\mathrm{kWh} / \mathrm{yr})\end{array}$ & $\begin{array}{c}\text { Thermal } \\
\text { Savings } \\
\mathbf{( M i l .} \\
\text { Btu/yr) }\end{array}$ & $\begin{array}{c}\text { Annual } \\
\text { Cost } \\
\text { Savings }\end{array}$ & $\begin{array}{c}\text { Implementation } \\
\text { Costs }\end{array}$ & $\begin{array}{c}\text { Payback } \\
\text { Period } \\
\text { (yrs) }\end{array}$ \\
\hline Reduce infiltration & 15,644 & 758 & $\$ 7,366$ & $\$ 16,406$ & 2.2 \\
\hline High efficiency lighting & 35,378 & -63 & $\$ 2,832$ & $\$ 52,807$ & 18.6 \\
\hline Wall insulation & 2,474 & 260 & $\$ 2,255$ & $\$ 13,723$ & 6.1 \\
\hline Night setback of thermostat temperatures & 13,544 & 236 & $\$ 3,108$ & $\$ 446$ & 0.1 \\
\hline Total & 67,039 & 1,191 & $\$ 15,561$ & $\$ 83,382$ & 5.4 \\
\hline
\end{tabular}

Table 114. Bldg. 1, Fort Bliss, savings and payback summary, Climate Zone 4B (Albuquerque, NM).

\begin{tabular}{|l|c|c|c|c|c|}
\hline & $\begin{array}{l}\text { Electrical } \\
\text { Savings } \\
(\mathbf{k W h} / \mathbf{y r})\end{array}$ & $\begin{array}{c}\text { Thermal } \\
\text { Savings } \\
\mathbf{( M i l .} \\
\text { Btu/yr) }\end{array}$ & $\begin{array}{c}\text { Annual } \\
\text { Cost } \\
\text { Savings }\end{array}$ & $\begin{array}{c}\text { Implementation } \\
\text { Costs }\end{array}$ & $\begin{array}{c}\text { Payback } \\
\text { Period } \\
\text { (yrs) }\end{array}$ \\
\hline Reduce infiltration & 9,357 & 580 & $\$ 5,391$ & $\$ 16,406$ & 3.0 \\
\hline High efficiency lighting & 35,602 & -56 & $\$ 2,907$ & $\$ 52,807$ & 18.2 \\
\hline Wall insulation & -11 & 191 & $\$ 1,485$ & $\$ 13,723$ & 9.2 \\
\hline Night setback of thermostat temperatures & 13,255 & 193 & $\$ 2,746$ & $\$ 446$ & 0.2 \\
\hline Total & $\mathbf{5 8 , 2 0 3}$ & $\mathbf{9 0 8}$ & $\mathbf{\$ 1 2 , 5 3 0}$ & $\$ 83,382$ & 6.7 \\
\hline
\end{tabular}


Table 115. Bldg. 1, Fort Bliss, savings and payback summary, Climate Zone 4C (Seattle, WA).

\begin{tabular}{|l|c|c|c|c|c|}
\hline EEM & $\begin{array}{c}\text { Electrical } \\
\text { Savings } \\
(\mathbf{k W h} / \mathbf{y r})\end{array}$ & $\begin{array}{c}\text { Thermal } \\
\text { Savings } \\
\text { (Mil. } \\
\text { Btu/yr) }\end{array}$ & $\begin{array}{c}\text { Annual } \\
\text { Cost } \\
\text { Savings }\end{array}$ & $\begin{array}{c}\text { Implementation } \\
\text { Costs }\end{array}$ & $\begin{array}{c}\text { Payback } \\
\text { Period } \\
\text { (yrs) }\end{array}$ \\
\hline Reduce infiltration & 10,835 & 814 & $\$ 7,350$ & $\$ 16,406$ & 2.2 \\
\hline High efficiency lighting & 33,718 & -86 & $\$ 2,497$ & $\$ 52,807$ & 21.1 \\
\hline Wall insulation & $-4,809$ & 269 & $\$ 1,641$ & $\$ 13,723$ & 8.4 \\
\hline Night setback of thermostat temperatures & 16,433 & 294 & $\$ 3,830$ & $\$ 446$ & 0.1 \\
\hline Total & 56,176 & 1,291 & $\$ 15,319$ & $\$ 83,382$ & 5.4 \\
\hline
\end{tabular}

Table 116. Bldg. 1, Fort Bliss, savings and payback summary, Climate Zone 5A (Chicago, IL).

\begin{tabular}{|l|c|c|c|c|c|}
\hline EEM & $\begin{array}{c}\text { Electrical } \\
\text { Savings } \\
(\mathbf{k W h} / \mathbf{y r})\end{array}$ & $\begin{array}{c}\text { Thermal } \\
\text { Savings } \\
\text { (Mil. } \\
\text { Btu/yr) }\end{array}$ & $\begin{array}{c}\text { Annual } \\
\text { Cost } \\
\text { Savings }\end{array}$ & $\begin{array}{c}\text { Implementation } \\
\text { Costs }\end{array}$ & $\begin{array}{c}\text { Payback } \\
\text { Period } \\
\text { (yrs) }\end{array}$ \\
\hline Reduce infiltration & 12,857 & 947 & $\$ 8,575$ & $\$ 16,406$ & 1.9 \\
\hline High efficiency lighting & 34,748 & -72 & $\$ 2,703$ & $\$ 52,807$ & 19.5 \\
\hline Wall insulation & 735 & 353 & $\$ 2,815$ & $\$ 13,723$ & 4.9 \\
\hline Night setback of thermostat temperatures & 12,646 & 278 & $\$ 3,350$ & $\$ 446$ & 0.1 \\
\hline Total & 60,985 & 1,507 & $\$ 17,451$ & $\$ 83,382$ & 4.8 \\
\hline
\end{tabular}

Table 117. Bldg. 1, Fort Bliss, savings and payback summary, Climate Zone 5B (Colorado Springs, C0).

\begin{tabular}{|l|c|c|c|c|c|}
\hline EEM & $\begin{array}{c}\text { Electrical } \\
\text { Savings } \\
\text { (kWh/yr) }\end{array}$ & $\begin{array}{c}\text { Thermal } \\
\text { Savings } \\
\text { (Mil. } \\
\text { Btu/yr) }\end{array}$ & $\begin{array}{c}\text { Annual } \\
\text { Cost } \\
\text { Savings }\end{array}$ & $\begin{array}{c}\text { Implementation } \\
\text { Costs }\end{array}$ & $\begin{array}{c}\text { Payback } \\
\text { Period } \\
\text { (yrs) }\end{array}$ \\
\hline Reduce infiltration & 7,618 & 802 & $\$ 6,955$ & $\$ 16,406$ & 2.4 \\
\hline High efficiency lighting & 34,115 & -74 & $\$ 2,628$ & $\$ 52,807$ & 20.1 \\
\hline Wall insulation & $-3,522$ & 315 & $\$ 2,120$ & $\$ 13,723$ & 6.5 \\
\hline Night setback of thermostat temperatures & 13,358 & 266 & $\$ 3,324$ & $\$ 446$ & 0.1 \\
\hline Total & $\mathbf{5 1 , 5 7 0}$ & $\mathbf{1 , 3 0 9}$ & $\mathbf{\$ 1 5 , 0 2 6}$ & $\$ 83,382$ & $\mathbf{5 . 5}$ \\
\hline
\end{tabular}

Table 118. Bldg. 1, Fort Bliss, savings and payback summary, Climate Zone 6A (Burlington, VT).

\begin{tabular}{|l|c|c|c|c|c|}
\hline EEM & $\begin{array}{c}\text { Electrical } \\
\text { Savings } \\
(\mathbf{k W h} / \mathbf{y r})\end{array}$ & $\begin{array}{c}\text { Thermal } \\
\text { Savings } \\
\text { (Mil. } \\
\text { Btu/yr) }\end{array}$ & $\begin{array}{c}\text { Annual } \\
\text { Cost } \\
\text { Savings }\end{array}$ & $\begin{array}{c}\text { Implementation } \\
\text { Costs }\end{array}$ & $\begin{array}{c}\text { Payback } \\
\text { Period } \\
\text { (yrs) }\end{array}$ \\
\hline Reduce infiltration & 13,058 & 1,133 & $\$ 10,041$ & $\$ 16,406$ & 1.6 \\
\hline High efficiency lighting & 34,101 & -82 & $\$ 2,564$ & $\$ 52,807$ & 20.6 \\
\hline Wall insulation & $-1,016$ & 407 & $\$ 3,071$ & $\$ 13,723$ & 4.5 \\
\hline Night setback of thermostat temperatures & 12,749 & 311 & $\$ 3,617$ & $\$ 446$ & 0.1 \\
\hline Total & 58,892 & 2,930 & $\$ 28,325$ & $\$ 83,382$ & 2.9 \\
\hline
\end{tabular}


Table 119. Bldg. 1, Fort Bliss, savings and payback summary, Climate Zone 6B (Helena, MT).

\begin{tabular}{|l|c|c|c|c|c|}
\hline EEM & $\begin{array}{c}\text { Electrical } \\
\text { Savings } \\
(\mathbf{k W h} / \mathrm{yr})\end{array}$ & $\begin{array}{c}\text { Thermal } \\
\text { Savings } \\
\text { (Mil. } \\
\text { Btu/yr) }\end{array}$ & $\begin{array}{c}\text { Annual } \\
\text { Cost } \\
\text { Savings }\end{array}$ & $\begin{array}{c}\text { Implementation } \\
\text { Costs }\end{array}$ & $\begin{array}{c}\text { Payback } \\
\text { Period } \\
\text { (yrs) }\end{array}$ \\
\hline Reduce infiltration & 9,151 & 1,012 & $\$ 8,733$ & $\$ 16,406$ & 1.9 \\
\hline High efficiency lighting & 33,774 & -83 & $\$ 2,526$ & $\$ 52,807$ & 20.9 \\
\hline Wall insulation & $-2,221$ & 398 & $\$ 2,888$ & $\$ 13,723$ & 4.8 \\
\hline Night setback of thermostat temperatures & 13,444 & 297 & $\$ 3,573$ & $\$ 446$ & 0.1 \\
\hline Total & $\mathbf{5 4 , 1 4 8}$ & $\mathbf{1 , 6 2 4}$ & $\mathbf{\$ 1 7 , 7 1 9}$ & $\$ 83,382$ & 4.7 \\
\hline
\end{tabular}

Table 120. Bldg. 1, Fort Bliss, savings and payback summary, Climate Zone 7A (Duluth, MN).

\begin{tabular}{|l|c|c|c|c|c|}
\hline EEM & $\begin{array}{c}\text { Electrical } \\
\text { Savings } \\
(\mathbf{k W h} / \mathbf{y r})\end{array}$ & $\begin{array}{c}\text { Thermal } \\
\text { Savings } \\
\text { (Mil. } \\
\text { Btu/yr) }\end{array}$ & $\begin{array}{c}\text { Annual } \\
\text { Cost } \\
\text { Savings }\end{array}$ & $\begin{array}{c}\text { Implementation } \\
\text { Costs }\end{array}$ & $\begin{array}{c}\text { Payback } \\
\text { Period } \\
\text { (yrs) }\end{array}$ \\
\hline Reduce infiltration & 9,300 & 1,361 & $\$ 11,462$ & $\$ 16,406$ & 1.4 \\
\hline High efficiency lighting & 33,044 & -91 & $\$ 2,395$ & $\$ 52,807$ & 22.1 \\
\hline Wall insulation & $-2,776$ & 535 & $\$ 3,902$ & $\$ 13,723$ & 3.5 \\
\hline Night setback of thermostat temperatures & 12,121 & 364 & $\$ 3,970$ & $\$ 446$ & 0.1 \\
\hline Total & 51,689 & 2,169 & $\$ 21,728$ & $\$ 83,382$ & 3.8 \\
\hline
\end{tabular}

Table 121. Bldg. 1, Fort Bliss, savings and payback summary, Climate Zone 8A (Fairbanks, AK).

\begin{tabular}{|l|c|c|c|c|c|}
\hline EEM & $\begin{array}{c}\text { Electrical } \\
\text { Savings } \\
\text { (kWh/yr) }\end{array}$ & $\begin{array}{c}\text { Thermal } \\
\text { Savings } \\
\text { (Mil. } \\
\text { Btu/yr) }\end{array}$ & $\begin{array}{c}\text { Annual } \\
\text { Cost } \\
\text { Savings }\end{array}$ & $\begin{array}{c}\text { Implementation } \\
\text { Costs }\end{array}$ & $\begin{array}{c}\text { Payback } \\
\text { Period } \\
\text { (yrs) }\end{array}$ \\
\hline Reduce infiltration & 26,828 & 1,940 & $\$ 17,612$ & $\$ 16,406$ & 0.9 \\
\hline High efficiency lighting & 30,156 & -102 & $\$ 2,038$ & $\$ 52,807$ & 25.9 \\
\hline Wall insulation & 2,432 & 727 & $\$ 5,884$ & $\$ 13,723$ & 2.3 \\
\hline Night setback of thermostat temperatures & 8,739 & 380 & $\$ 3,777$ & $\$ 446$ & 0.1 \\
\hline Total & 68,155 & 2,960 & $\$ 29,429$ & $\$ 83,382$ & 2.8 \\
\hline
\end{tabular}

Figure 71. Bldg. 1, Fort Bliss, annual cost savings resulting from EEM “Reduce Infiltration," by climate zone.

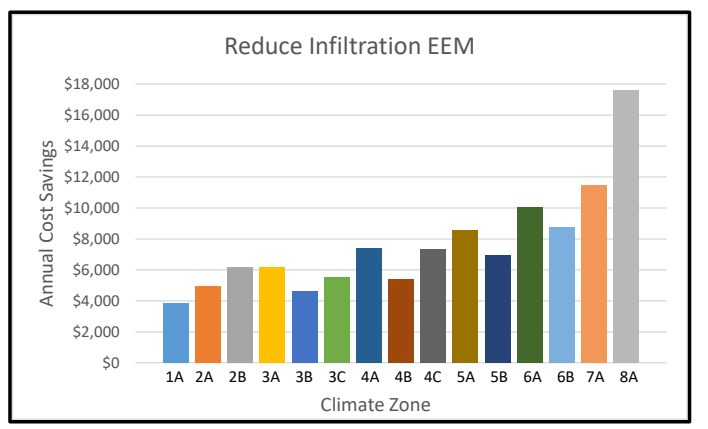

Figure 72. Bldg. 1, Fort Bliss, simple payback resulting from EEM “Reduce Infiltration," by climate zone.

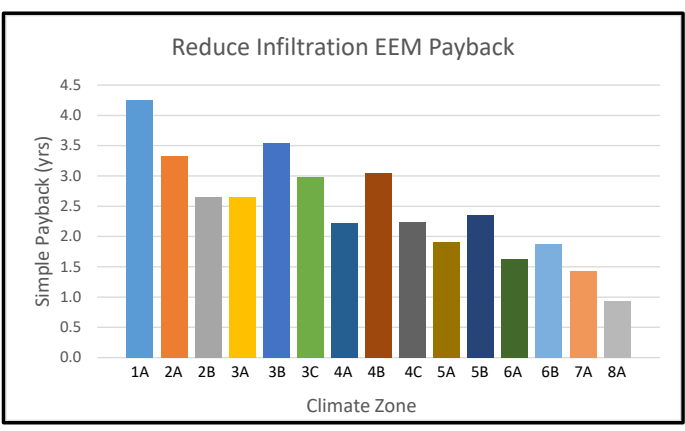


Figure 73. Bldg. 1, Fort Bliss, annual cost savings resulting from EEM "High Efficiency Lighting," by climate zone.

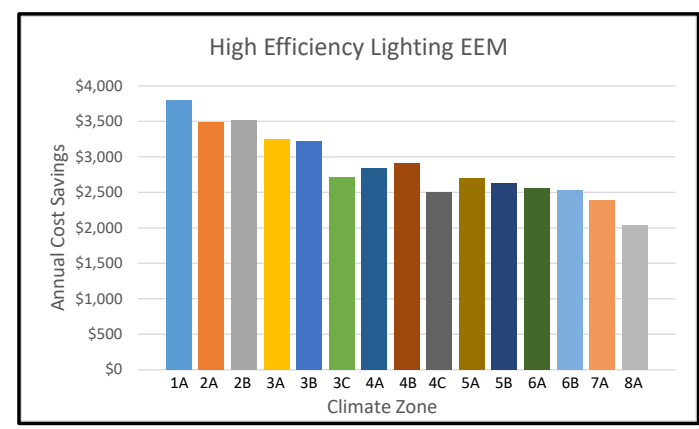

Figure 75. Bldg. 1, Fort Bliss, annual cost savings resulting from EEM "Wall Insulation," by climate zone.

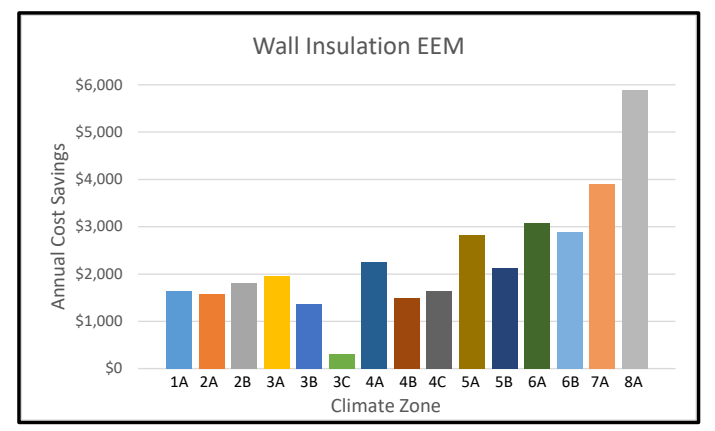

Figure 77. Bldg. 1, Fort Bliss, annual cost savings resulting from EEM "Night Setback of Thermostat Temperatures EEM," by climate zone.

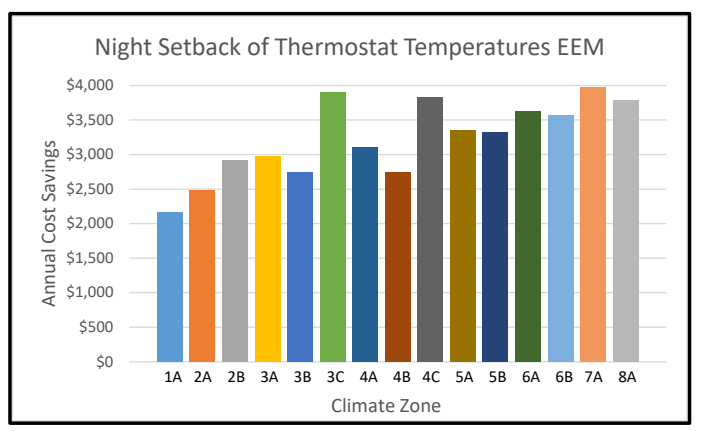

Figure 74. Bldg. 1, Fort Bliss, simple payback resulting from EEM "High Efficiency Lighting," by climate zone.

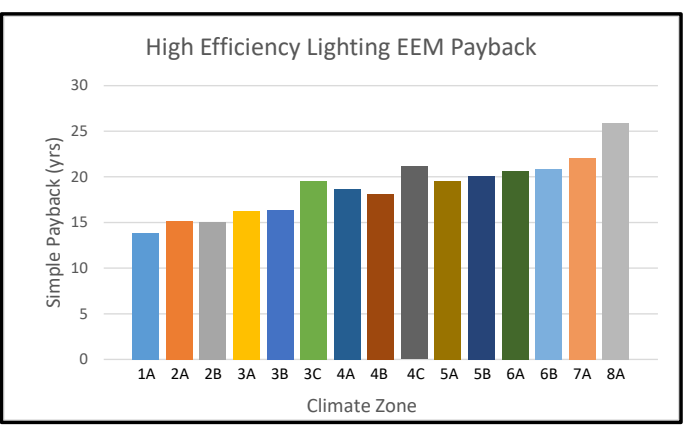

Figure 76. Bldg. 1, Fort Bliss, simple payback resulting from EEM "Wall Insulation," by climate zone.

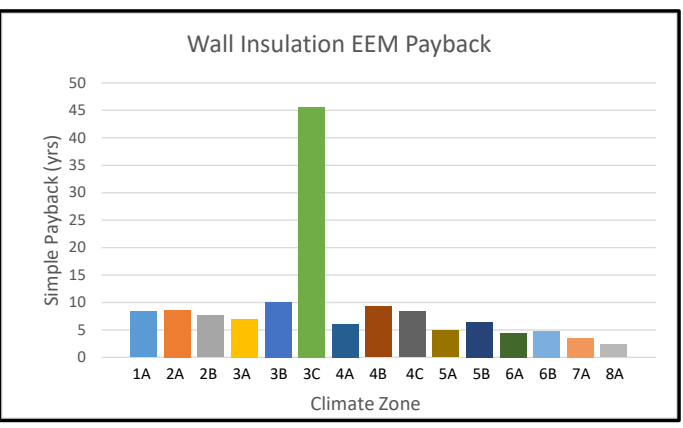

Figure 78. Bldg. 1, Fort Bliss, simple payback resulting from EEM "Night Setback of Thermostat Temperatures EEM," by climate zone.

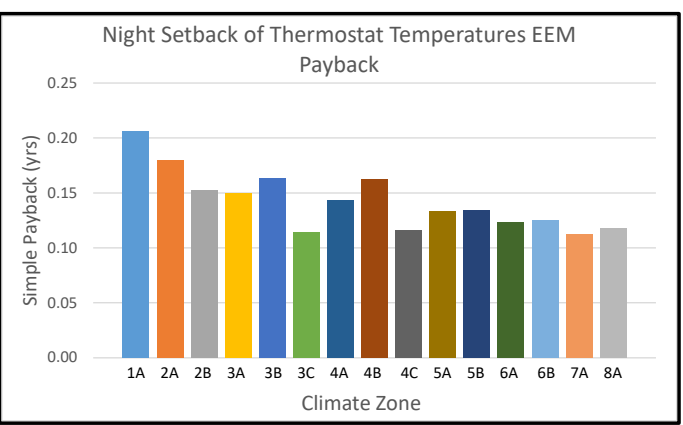


Figure 79. Bldg. 1, Fort Bliss, total EEM payback, by climate zone.

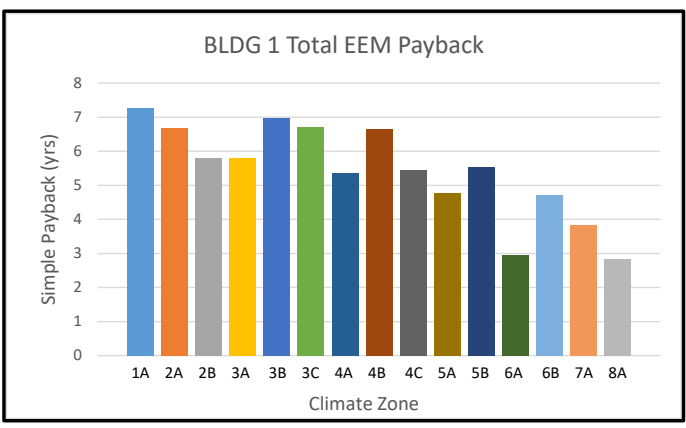

\subsubsection{Bldg. 115 EEM savings by climate zone}

The EEMs chosen for Bldg. 115 were those with a simple payback of under 30 years, for the actual location of the building in El Paso, TX. These were:

- Reduce Infiltration. The building infiltration was changed from 2.00 $\mathrm{ACH}$ to $1.00 \mathrm{ACH}$.

- High Efficiency Lighting. The lighting power densities of the building were changed. Figure 80 shows the specifications.

- Night setback of thermostat temperatures (changed the unoccupied cooling and heating setpoints from 73 and $68^{\circ} \mathrm{F}$, to 85 and $61^{\circ} \mathrm{F}$, respectively. The occupancy schedule was also changed for the second floor from 24 hours per day, to 0700-1800 M-F and 0700-1300 Sa, and unoccupied Sunday and Holidays.)

Figure 80. Bldg. 1, Fort Bliss, lighting power density specifications.

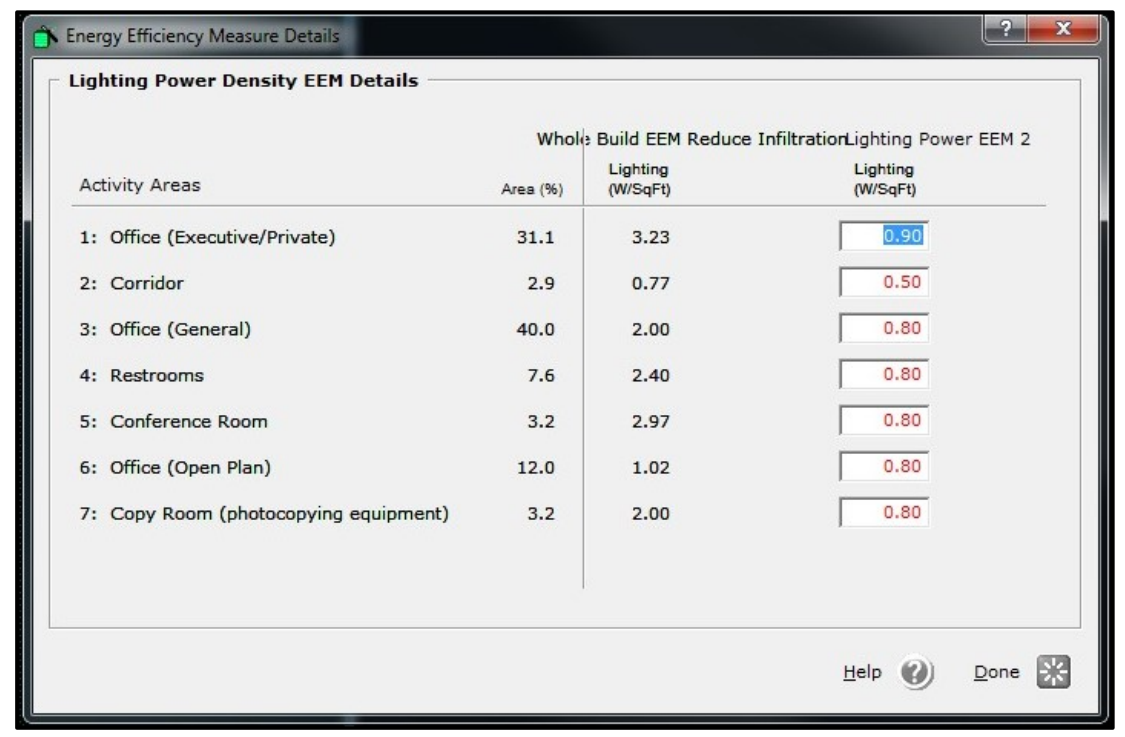


The model was then run in each of the different climate zones using eQUEST. The results are listed in Tables 122-136 and shown in Figures 81-87.

Table 122. Bldg. 115 savings and payback summary, Climate Zone 1A (Miami, FL).

\begin{tabular}{|l|c|c|c|c|c|}
\hline & $\begin{array}{c}\text { Electrical } \\
\text { Savings } \\
(\mathbf{k W h} / \mathbf{y r})\end{array}$ & $\begin{array}{c}\text { Thermal } \\
\text { Savings } \\
\mathbf{( M i l .} \\
\text { Btu/yr) }\end{array}$ & $\begin{array}{c}\text { Annual } \\
\text { Cost } \\
\text { Savings }\end{array}$ & $\begin{array}{c}\text { Implementation } \\
\text { Costs }\end{array}$ & $\begin{array}{c}\text { Payback } \\
\text { Period (yrs) }\end{array}$ \\
\hline Reduce infiltration & 12,376 & 0 & $\$ 1,162$ & $\$ 11,181$ & 9.6 \\
\hline High efficiency lighting & 62,647 & 0 & $\$ 5,883$ & $\$ 29,485$ & 5.0 \\
\hline Night setback of thermostat temperatures & 24,523 & 0 & $\$ 2,303$ & $\$ 446$ & 0.2 \\
\hline Total & $\mathbf{9 9 , 5 4 6}$ & $\mathbf{0}$ & $\mathbf{\$ 9 , 3 4 7}$ & $\mathbf{\$ 4 1 , 1 1 2}$ & $\mathbf{4 . 4}$ \\
\hline
\end{tabular}

Table 123. Bldg. 115 savings and payback summary, Climate Zone 2A (Houston, TX).

\begin{tabular}{|l|c|c|c|c|c|}
\hline EEM & $\begin{array}{c}\text { Electrical } \\
\text { Savings } \\
\text { (kWh/yr) }\end{array}$ & $\begin{array}{c}\text { Thermal } \\
\text { Savings } \\
\text { (Mil. } \\
\text { Btu/yr) }\end{array}$ & $\begin{array}{c}\text { Annual } \\
\text { Cost } \\
\text { Savings }\end{array}$ & $\begin{array}{c}\text { Implementation } \\
\text { Costs }\end{array}$ & $\begin{array}{c}\text { Payback } \\
\text { Period (yrs) }\end{array}$ \\
\hline Reduce infiltration & 13,537 & 0 & $\$ 1,271$ & $\$ 11,181$ & 8.8 \\
\hline High efficiency lighting & 56,513 & 0 & $\$ 5,307$ & $\$ 29,485$ & 5.6 \\
\hline Night setback of thermostat temperatures & 22,341 & 0 & $\$ 2,098$ & $\$ 446$ & 0.2 \\
\hline Total & $\mathbf{9 2 , 3 9 1}$ & 0 & $\$ \mathbf{\$ 8 , 6 7 6}$ & $\mathbf{\$ 4 1 , 1 1 2}$ & $\mathbf{4 . 7}$ \\
\hline
\end{tabular}

Table 124. Bldg. 115 savings and payback summary, Climate Zone 2B (Phoenix, AZ).

\begin{tabular}{|l|c|c|c|c|c|}
\hline EEM & $\begin{array}{c}\text { Electrical } \\
\text { Savings } \\
(\mathbf{k W h} / \mathbf{y r})\end{array}$ & $\begin{array}{c}\text { Thermal } \\
\text { Savings } \\
\mathbf{( M i l .} \\
\text { Btu/yr) }\end{array}$ & $\begin{array}{c}\text { Annual } \\
\text { Cost } \\
\text { Savings }\end{array}$ & $\begin{array}{c}\text { Implementation } \\
\text { Costs }\end{array}$ & $\begin{array}{c}\text { Payback } \\
\text { Period (yrs) }\end{array}$ \\
\hline Reduce infiltration & 14,151 & 0 & $\$ 1,329$ & $\$ 11,181$ & 8.4 \\
\hline High efficiency lighting & 56,630 & 0 & $\$ 5,318$ & $\$ 29,485$ & 5.5 \\
\hline Night setback of thermostat temperatures & 22,510 & 0 & $\$ 2,114$ & $\$ 446$ & 0.2 \\
\hline Total & $\mathbf{9 3 , 2 9 0}$ & 0 & $\$ 8,760$ & $\$ 41,112$ & 4.7 \\
\hline
\end{tabular}

Table 125. Bldg. 115 savings and payback summary, Climate Zone 3A (Memphis, TN).

\begin{tabular}{|l|c|c|c|c|c|}
\hline EEM & $\begin{array}{c}\text { Electrical } \\
\text { Savings } \\
(\mathbf{k W h} / \mathbf{y r})\end{array}$ & $\begin{array}{c}\text { Thermal } \\
\text { Savings } \\
\mathbf{( M i l .} \\
\text { Btu/yr) }\end{array}$ & $\begin{array}{c}\text { Annual } \\
\text { Cost } \\
\text { Savings }\end{array}$ & $\begin{array}{c}\text { Implementation } \\
\text { Costs }\end{array}$ & $\begin{array}{c}\text { Payback } \\
\text { Period (yrs) }\end{array}$ \\
\hline Reduce infiltration & 14,437 & 0 & $\$ 1,356$ & $\$ 11,181$ & 8.2 \\
\hline High efficiency lighting & 51,750 & 0 & $\$ 4,859$ & $\$ 29,485$ & 6.1 \\
\hline Night setback of thermostat temperatures & 21,383 & 0 & $\$ 2,008$ & $\$ 446$ & 0.2 \\
\hline Total & $\mathbf{8 7 , 5 7 1}$ & $\mathbf{0}$ & $\mathbf{\$ 8 , 2 2 3}$ & $\mathbf{\$ 4 1 , 1 1 2}$ & $\mathbf{5 . 0}$ \\
\hline
\end{tabular}


Table 126. Bldg. 115 savings and payback summary, Climate Zone 3B (EI Paso, TX).

\begin{tabular}{|l|c|c|c|c|c|}
\hline EEM & $\begin{array}{c}\text { Electrical } \\
\text { Savings } \\
(\mathbf{k W h} / \mathbf{y r})\end{array}$ & $\begin{array}{c}\text { Thermal } \\
\text { Savings } \\
\mathbf{( M i l .} \\
\text { Btu/yr) }\end{array}$ & $\begin{array}{c}\text { Annual } \\
\text { Cost } \\
\text { Savings }\end{array}$ & $\begin{array}{c}\text { Implementation } \\
\text { Costs }\end{array}$ & $\begin{array}{c}\text { Payback } \\
\text { Period (yrs) }\end{array}$ \\
\hline Reduce infiltration & 9,528 & 0 & $\$ 895$ & $\$ 11,181$ & 12.5 \\
\hline High efficiency lighting & 53,118 & 0 & $\$ 4,988$ & $\$ 29,485$ & 5.9 \\
\hline Night setback of thermostat temperatures & 19,119 & 0 & $\$ 1,795$ & $\$ 446$ & 0.2 \\
\hline Total & $\mathbf{8 1 , 7 6 5}$ & $\mathbf{0}$ & $\mathbf{\$ 7 , 6 7 8}$ & $\mathbf{\$ 4 1 , 1 1 2}$ & $\mathbf{5 . 4}$ \\
\hline
\end{tabular}

Table 127. Bldg. 115 savings and payback summary, Climate Zone 3C (San Francisco, CA).

\begin{tabular}{|l|c|c|c|c|c|}
\hline EEM & $\begin{array}{c}\text { Electrical } \\
\text { Savings } \\
(\mathbf{k W h} / \mathbf{y r})\end{array}$ & $\begin{array}{c}\text { Thermal } \\
\text { Savings } \\
\mathbf{( M i l .} \\
\text { Btu/yr) }\end{array}$ & $\begin{array}{c}\text { Annual } \\
\text { Cost } \\
\text { Savings }\end{array}$ & $\begin{array}{c}\text { Implementation } \\
\text { Costs }\end{array}$ & $\begin{array}{c}\text { Payback } \\
\text { Period (yrs) }\end{array}$ \\
\hline Reduce infiltration & 6,573 & 0 & $\$ 617$ & $\$ 11,181$ & 18.1 \\
\hline High efficiency lighting & 46,602 & 0 & $\$ 4,376$ & $\$ 29,485$ & 6.7 \\
\hline Night setback of thermostat temperatures & 10,072 & 0 & $\$ 946$ & $\$ 446$ & 0.5 \\
\hline Total & $\mathbf{6 3 , 2 4 7}$ & 0 & $\$ 5,939$ & $\$ 41,112$ & 6.9 \\
\hline
\end{tabular}

Table 128. Bldg. 115 savings and payback summary, Climate Zone 4A (Baltimore, MD).

\begin{tabular}{|l|c|c|c|c|c|}
\hline EEM & $\begin{array}{c}\text { Electrical } \\
\text { Savings } \\
(\mathbf{k W h} / \mathbf{y r})\end{array}$ & $\begin{array}{c}\text { Thermal } \\
\text { Savings } \\
\mathbf{( M i l .} \\
\text { Btu/yr) }\end{array}$ & $\begin{array}{c}\text { Annual } \\
\text { Cost } \\
\text { Savings }\end{array}$ & $\begin{array}{c}\text { Implementation } \\
\text { Costs }\end{array}$ & $\begin{array}{c}\text { Payback } \\
\text { Period (yrs) }\end{array}$ \\
\hline Reduce infiltration & 18,815 & 0 & $\$ 1,767$ & $\$ 11,181$ & 6.3 \\
\hline High efficiency lighting & 46,955 & 0 & $\$ 4,409$ & $\$ 29,485$ & 6.7 \\
\hline Night setback of thermostat temperatures & 22,788 & 0 & $\$ 2,140$ & $\$ 446$ & 0.2 \\
\hline Total & $\mathbf{8 8 , 5 5 9}$ & $\mathbf{0}$ & $\mathbf{\$ 8 , 3 1 6}$ & $\mathbf{\$ 4 1 , 1 1 2}$ & $\mathbf{4 . 9}$ \\
\hline
\end{tabular}

Table 129. Bldg. 115 savings and payback summary, Climate Zone 4B (Albuquerque, NM).

\begin{tabular}{|l|c|c|c|c|c|}
\hline & $\begin{array}{c}\text { Electrical } \\
\text { Savings } \\
(\mathbf{k W h} / \mathbf{y r})\end{array}$ & $\begin{array}{c}\text { Thermal } \\
\text { Savings } \\
\mathbf{( M i l .} \\
\text { Btu/yr) }\end{array}$ & $\begin{array}{c}\text { Annual } \\
\text { Cost } \\
\text { Savings }\end{array}$ & $\begin{array}{c}\text { Implementation } \\
\text { Costs }\end{array}$ & $\begin{array}{c}\text { Payback } \\
\text { Period (yrs) }\end{array}$ \\
\hline Reduce infiltration & 11,929 & 0 & $\$ 1,120$ & $\$ 11,181$ & 10.0 \\
\hline High efficiency lighting & 47,630 & 0 & $\$ 4,472$ & $\$ 29,485$ & 6.6 \\
\hline Night setback of thermostat temperatures & 18,158 & 0 & $\$ 1,705$ & $\$ 446$ & 0.3 \\
\hline Total & 77,717 & 0 & $\$ 7,298$ & $\$ 41,112$ & 5.6 \\
\hline
\end{tabular}

Table 130. Bldg. 115 savings and payback summary, Climate Zone 4C (Seattle, WA).

\begin{tabular}{|l|c|c|c|c|c|}
\hline EEM & $\begin{array}{c}\text { Electrical } \\
\text { Savings } \\
(\mathrm{kWh} / \mathrm{yr})\end{array}$ & $\begin{array}{c}\text { Thermal } \\
\text { Savings } \\
\mathbf{( M i l .} \\
\text { Btu/yr) }\end{array}$ & $\begin{array}{c}\text { Annual } \\
\text { Cost } \\
\text { Savings }\end{array}$ & $\begin{array}{c}\text { Implementation } \\
\text { Costs }\end{array}$ & $\begin{array}{c}\text { Payback } \\
\text { Period (yrs) }\end{array}$ \\
\hline Reduce infiltration & 12,433 & 0 & $\$ 1,167$ & $\$ 11,181$ & 9.6 \\
\hline High efficiency lighting & 44,297 & 0 & $\$ 4,159$ & $\$ 29,485$ & 7.1 \\
\hline Night setback of thermostat temperatures & 16,276 & 0 & $\$ 1,528$ & $\$ 446$ & 0.3 \\
\hline Total & 73,007 & 0 & $\$ 6,855$ & $\$ 41,112$ & 6.0 \\
\hline
\end{tabular}


Table 131. Bldg. 115 savings and payback summary, Climate Zone 5A (Chicago, IL).

\begin{tabular}{|l|c|c|c|c|c|}
\hline EEM & $\begin{array}{c}\text { Electrical } \\
\text { Savings } \\
(\mathrm{kWh} / \mathrm{yr})\end{array}$ & $\begin{array}{c}\text { Thermal } \\
\text { Savings } \\
\mathbf{( M i l .} \\
\text { Btu/yr) }\end{array}$ & $\begin{array}{c}\text { Annual } \\
\text { Cost } \\
\text { Savings }\end{array}$ & $\begin{array}{c}\text { Implementation } \\
\text { Costs }\end{array}$ & $\begin{array}{c}\text { Payback } \\
\text { Period (yrs) }\end{array}$ \\
\hline Reduce infiltration & 29,316 & 0 & $\$ 2,753$ & $\$ 11,181$ & 4.1 \\
\hline High efficiency lighting & 39,340 & 0 & $\$ 3,694$ & $\$ 29,485$ & 8.0 \\
\hline Night setback of thermostat temperatures & 28,011 & 0 & $\$ 2,630$ & $\$ 446$ & 0.2 \\
\hline Total & 96,667 & 0 & $\$ 9,077$ & $\$ 41,112$ & 4.5 \\
\hline
\end{tabular}

Table 132. Bldg. 115 savings and payback summary, Climate Zone 5B (Colorado Springs, C0).

\begin{tabular}{|l|c|c|c|c|c|}
\hline EEM & $\begin{array}{c}\text { Electrical } \\
\text { Savings } \\
\mathbf{( k W h / y r )}\end{array}$ & $\begin{array}{c}\text { Thermal } \\
\text { Savings (Mil. } \\
\text { Btu/yr) }\end{array}$ & $\begin{array}{c}\text { Annual } \\
\text { Cost } \\
\text { Savings }\end{array}$ & $\begin{array}{c}\text { Implementation } \\
\text { Costs }\end{array}$ & $\begin{array}{c}\text { Payback } \\
\text { Period (yrs) }\end{array}$ \\
\hline Reduce infiltration & 19,172 & 0 & $\$ 1,800$ & $\$ 11,181$ & 6.2 \\
\hline High efficiency lighting & 40,350 & 0 & $\$ 3,789$ & $\$ 29,485$ & 7.8 \\
\hline Night setback of thermostat temperatures & 24,429 & 0 & $\$ 2,294$ & $\$ 446$ & 0.2 \\
\hline Total & $\mathbf{8 3 , 9 5 0}$ & $\mathbf{0}$ & $\mathbf{\$ 7 , 8 8 3}$ & $\mathbf{\$ 4 1 , 1 1 2}$ & $\mathbf{5 . 2}$ \\
\hline
\end{tabular}

Table 133. Bldg. 115 savings and payback summary, Climate Zone 6A (Burlington, VT).

\begin{tabular}{|l|c|c|c|c|c|}
\hline EEM & $\begin{array}{c}\text { Electrical } \\
\text { Savings } \\
(\mathbf{k W h} / \mathbf{y r})\end{array}$ & $\begin{array}{c}\text { Thermal } \\
\text { Savings (Mil. } \\
\text { Btu/yr) }\end{array}$ & $\begin{array}{c}\text { Annual } \\
\text { Cost } \\
\text { Savings }\end{array}$ & $\begin{array}{c}\text { Implementation } \\
\text { Costs }\end{array}$ & $\begin{array}{c}\text { Payback } \\
\text { Period (yrs) }\end{array}$ \\
\hline Reduce infiltration & 35,403 & 0 & $\$ 3,324$ & $\$ 11,181$ & 3.4 \\
\hline High efficiency lighting & 36,992 & 0 & $\$ 3,474$ & $\$ 29,485$ & 8.5 \\
\hline Night setback of thermostat temperatures & 34,044 & 0 & $\$ 3,197$ & $\$ 446$ & 0.1 \\
\hline Total & 106,439 & 0 & $\$ 9,995$ & $\$ 41,112$ & 4.1 \\
\hline
\end{tabular}

Table 134. Bldg. 115 savings and payback summary, Climate Zone 6B (Helena, MT).

\begin{tabular}{|l|c|c|c|c|c|}
\hline EEM & $\begin{array}{c}\text { Electrical } \\
\text { Savings } \\
(\mathbf{k W h} / \mathbf{y r})\end{array}$ & $\begin{array}{c}\text { Thermal } \\
\text { Savings (Mil. } \\
\text { Btu/yr) }\end{array}$ & $\begin{array}{c}\text { Annual } \\
\text { Cost } \\
\text { Savings }\end{array}$ & $\begin{array}{c}\text { Implementation } \\
\text { Costs }\end{array}$ & $\begin{array}{c}\text { Payback } \\
\text { Period (yrs) }\end{array}$ \\
\hline Reduce infiltration & 30,197 & 0 & $\$ 2,835$ & $\$ 11,181$ & 3.9 \\
\hline High efficiency lighting & 36,158 & 0 & $\$ 3,395$ & $\$ 29,485$ & 8.7 \\
\hline Night setback of thermostat temperatures & 30,531 & 0 & $\$ 2,867$ & $\$ 446$ & 0.2 \\
\hline Total & 96,886 & 0 & $\$ 9,098$ & $\$ 41,112$ & 4.5 \\
\hline
\end{tabular}

Table 135. Bldg. 115 savings and payback summary, Climate Zone 7A (Duluth, MN).

\begin{tabular}{|l|c|c|c|c|c|}
\hline EEM & $\begin{array}{c}\text { Electrical } \\
\text { Savings } \\
\mathbf{( k W h / y r )}\end{array}$ & $\begin{array}{c}\text { Thermal } \\
\text { Savings (Mil. } \\
\text { Btu/yr) }\end{array}$ & $\begin{array}{c}\text { Annual } \\
\text { Cost } \\
\text { Savings }\end{array}$ & $\begin{array}{c}\text { Implementation } \\
\text { Costs }\end{array}$ & $\begin{array}{c}\text { Payback } \\
\text { Period (yrs) }\end{array}$ \\
\hline Reduce infiltration & 46,141 & 0 & $\$ 4,333$ & $\$ 11,181$ & 2.6 \\
\hline High efficiency lighting & 31,580 & 0 & $\$ 2,965$ & $\$ 29,485$ & 9.9 \\
\hline Night setback of thermostat temperatures & 44,883 & 0 & $\$ 4,215$ & $\$ 446$ & 0.1 \\
\hline Total & $\mathbf{1 2 2 , 6 0 4}$ & $\mathbf{0}$ & $\mathbf{\$ 1 1 , 5 1 3}$ & $\$ 41,112$ & $\mathbf{3 . 6}$ \\
\hline
\end{tabular}


Table 136. Bldg. 115 savings and payback summary, Climate Zone 8A (Fairbanks, AK).

\begin{tabular}{|l|c|c|c|c|c|}
\hline EEM & $\begin{array}{c}\text { Electrical } \\
\text { Savings } \\
(\mathbf{k W h} / \mathbf{y r})\end{array}$ & $\begin{array}{c}\text { Thermal } \\
\text { Savings (Mil. } \\
\text { Btu/yr) }\end{array}$ & $\begin{array}{c}\text { Annual } \\
\text { Cost } \\
\text { Savings }\end{array}$ & $\begin{array}{c}\text { Implementation } \\
\text { Costs }\end{array}$ & $\begin{array}{c}\text { Payback } \\
\text { Period (yrs) }\end{array}$ \\
\hline Reduce infiltration & 73,923 & 0 & $\$ 6,941$ & $\$ 11,181$ & 1.6 \\
\hline High efficiency lighting & 25,841 & 0 & $\$ 2,426$ & $\$ 29,485$ & 12.2 \\
\hline Night setback of thermostat temperatures & 71,538 & 0 & $\$ 6,717$ & $\$ 446$ & 0.1 \\
\hline Total & $\mathbf{1 7 1 , 3 0 2}$ & $\mathbf{0}$ & $\mathbf{\$ 1 6 , 0 8 5}$ & $\$ \mathbf{4 1 , 1 1 2}$ & $\mathbf{2 . 6}$ \\
\hline
\end{tabular}

Figure 81. Bldg. 115, Fort Bliss, annual cost savings resulting from EEM "Reduce Infiltration," by climate zone.

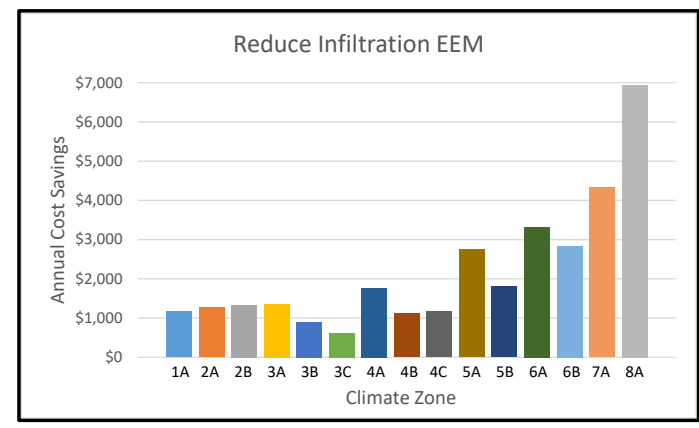

Figure 83. Bldg. 115, Fort Bliss, annual cost savings resulting from EEM “High Efficiency Lighting," by climate zone.

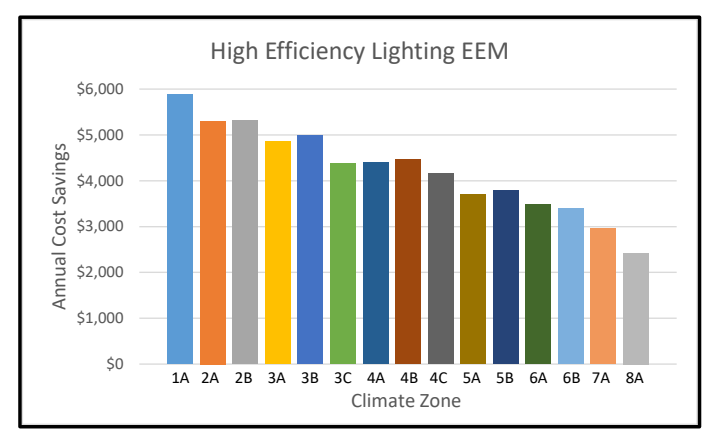

Figure 82. Bldg. 115, Fort Bliss, simple payback resulting from EEM "Reduce Infiltration," by climate zone.

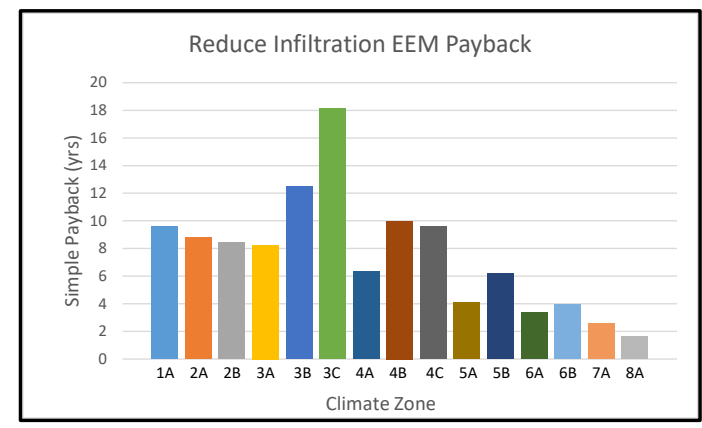

Figure 84. Bldg. 115, Fort Bliss, simple payback resulting from EEM “High Efficiency Lighting," by climate zone.

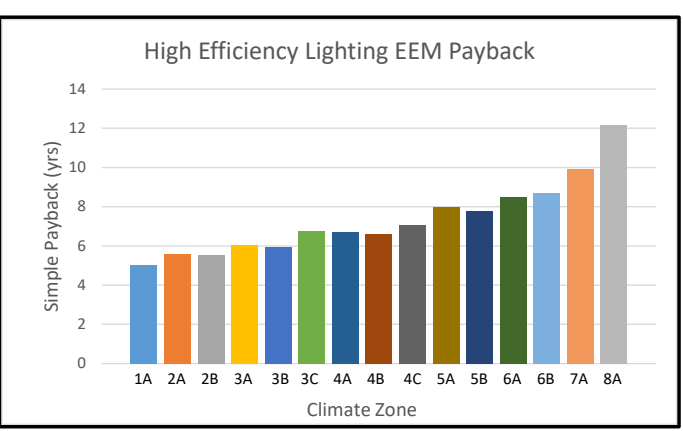


Figure 85. Bldg. 115, Fort Bliss, annual cost savings resulting from EEM "Night Setback of Thermostat Temperatures EEM," by climate zone.

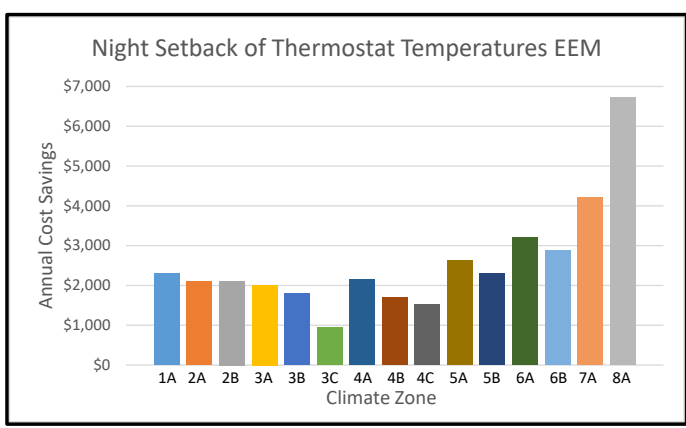

Figure 86. Bldg. 115, Fort Bliss, simple payback resulting from EEM “Night Setback of Thermostat Temperatures EEM," by climate zone.

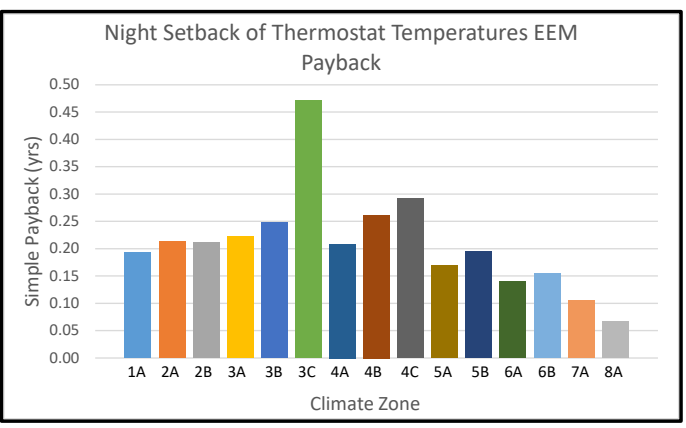

Figure 87. Bldg. 115, Fort Bliss, total EEM payback, by climate zone.

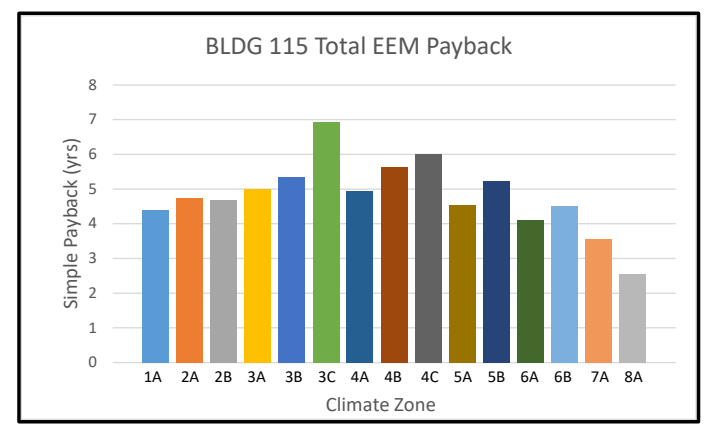

\subsubsection{Bldg. 1103 EEM savings by climate zone}

The EEMs chosen for Bldg. 1103 were those with a simple payback of under 30 years, for the actual location of the building in El Paso, TX. They were:

- Reduce Infiltration. The building infiltration was changed from 2.00 $\mathrm{ACH}$ to $1.00 \mathrm{ACH}$.

- Use Condensing Furnaces. The building's $65 \%$ efficiency boiler was replaced with a $90 \%$ efficiency boiler.

- Wall Insulation, R-13 wood furred interior insulation was added to the exterior building walls, where previously there was no insulation.

- Ground Floor Insulation. Three inches of polyurethane (R-18) exterior/cavity insulation were added to the ground floor, where previously there was no insulation. This can be done from underneath the floor since the building sits on pillars.

- Use Sky Lighting. The Daylighting option in eQUEST was enabled using the simplified method. One photo sensor was selected, and $100 \%$ of the building's lights were selected to use daylighting. The design light 
level was set at 40 footcandles, and the control method was set to allow light produced by the light fixtures to be reduced by up to $30 \%$ to take advantage of natural daylight.

The model was then run in each of the different climate zones using eQUEST. The results are listed in Tables 137-151 and shown in Figures 8898. Of note concerning the Sky Lighting ECM, reducing the power used for lighting produces a small penalty on the heating requirement since the (fewer) remaining lights produce correspondingly less heat.

Table 137. Bldg. 1103 savings and payback summary, Climate Zone 1A (Miami, FL).

\begin{tabular}{|l|c|c|c|c|c|}
\hline EEM & $\begin{array}{c}\text { Electrical } \\
\text { Savings } \\
(\mathrm{kWh} / \mathrm{yr})\end{array}$ & $\begin{array}{c}\text { Thermal } \\
\text { Savings } \\
\text { (Mil. } \\
\text { Btu/yr) }\end{array}$ & $\begin{array}{c}\text { Annual } \\
\text { Cost } \\
\text { Savings }\end{array}$ & $\begin{array}{c}\text { Implementation } \\
\text { Costs }\end{array}$ & $\begin{array}{c}\text { Payback } \\
\text { Period (yrs) }\end{array}$ \\
\hline Reduce Infiltration & -489 & 29 & $\$ 180$ & $\$ 9,183$ & 51.1 \\
\hline Use Condensing Furnaces & 0 & 23 & $\$ 179$ & $\$ 14,578$ & 81.5 \\
\hline Wall Insulation & 3,249 & 2 & $\$ 321$ & $\$ 6,596$ & 20.6 \\
\hline Ground Floor Insulation & 3,653 & 37 & $\$ 631$ & $\$ 55,002$ & 87.2 \\
\hline Use Sky Lighting & 8,882 & -1 & $\$ 826$ & $\$ 4,458$ & 5.4 \\
\hline Total & 15,295 & 89 & $\$ 2,129$ & $\$ 89,817$ & 42.2 \\
\hline
\end{tabular}

Table 138. Bldg. 1103 savings and payback summary, Climate Zone 2A (Houston, TX).

\begin{tabular}{|l|c|c|c|c|c|}
\hline EEM & $\begin{array}{c}\text { Electrical } \\
\text { Savings } \\
(\mathbf{k W h} / \mathbf{y r})\end{array}$ & $\begin{array}{c}\text { Thermal } \\
\text { Savings } \\
\mathbf{( M i l .} \\
\text { Btu/yr) }\end{array}$ & $\begin{array}{c}\text { Annual } \\
\text { Cost } \\
\text { Savings }\end{array}$ & $\begin{array}{c}\text { Implementation } \\
\text { Costs }\end{array}$ & $\begin{array}{c}\text { Payback } \\
\text { Period } \\
\text { (yrs) }\end{array}$ \\
\hline Reduce Infiltration & -92 & 95 & $\$ 730$ & $\$ 9,183$ & 12.6 \\
\hline Use Condensing Furnaces & 0 & 191 & $\$ 1,486$ & $\$ 14,578$ & 9.8 \\
\hline Wall Insulation & 2,240 & 15 & $\$ 327$ & $\$ 6,596$ & 20.2 \\
\hline Ground Floor Insulation & 3,267 & 160 & $\$ 1,552$ & $\$ 55,002$ & 35.4 \\
\hline Use Sky Lighting & 8,487 & -8 & $\$ 735$ & $\$ 4,458$ & 6.1 \\
\hline Total & 13,902 & 453 & $\$ 4,830$ & $\$ 89,817$ & 18.6 \\
\hline
\end{tabular}

Table 139. Bldg. 1103 savings and payback summary, Climate Zone 2B (Phoenix, AZ).

\begin{tabular}{|l|c|c|c|c|c|}
\hline EEM & $\begin{array}{c}\text { Electrical } \\
\text { Savings } \\
(\mathrm{kWh} / \mathrm{yr})\end{array}$ & $\begin{array}{c}\text { Thermal } \\
\text { Savings } \\
\mathbf{( M i l .} \\
\text { Btu/yr) }\end{array}$ & $\begin{array}{c}\text { Annual } \\
\text { Cost } \\
\text { Savings }\end{array}$ & $\begin{array}{c}\text { Implementation } \\
\text { Costs }\end{array}$ & $\begin{array}{c}\text { Payback } \\
\text { Period } \\
\text { (yrs })\end{array}$ \\
\hline Reduce Infiltration & 547 & 126 & $\$ 1,032$ & $\$ 9,183$ & 8.9 \\
\hline Use Condensing Furnaces & 0 & 158 & $\$ 1,229$ & $\$ 14,578$ & 11.9 \\
\hline Wall Insulation & 1,700 & 11 & $\$ 245$ & $\$ 6,596$ & 26.9 \\
\hline Ground Floor Insulation & 4,758 & 163 & $\$ 1,715$ & $\$ 55,002$ & 32.1 \\
\hline Use Sky Lighting & 8,364 & -7 & $\$ 731$ & $\$ 4,458$ & 6.1 \\
\hline Total & 15,369 & 451 & $\$ 4,952$ & $\$ 89,817$ & 18.1 \\
\hline
\end{tabular}


Table 140. Bldg. 1103 savings and payback summary, Climate Zone 3A (Memphis, TN).

\begin{tabular}{|l|c|c|c|c|c|}
\hline EEM & $\begin{array}{c}\text { Electrical } \\
\text { Savings } \\
(\mathrm{kWh} / \mathrm{yr})\end{array}$ & $\begin{array}{c}\text { Thermal } \\
\text { Savings } \\
\mathbf{( M i l .} \\
\text { Btu/yr) }\end{array}$ & $\begin{array}{c}\text { Annual } \\
\text { Cost } \\
\text { Savings }\end{array}$ & $\begin{array}{c}\text { Implementation } \\
\text { Costs }\end{array}$ & $\begin{array}{c}\text { Payback } \\
\text { Period } \\
(\mathrm{yrs})\end{array}$ \\
\hline Reduce Infiltration & 69 & 117 & $\$ 917$ & $\$ 9,183$ & 10.0 \\
\hline Use Condensing Furnaces & 0 & 337 & $\$ 2,622$ & $\$ 14,578$ & 5.6 \\
\hline Wall Insulation & 1,697 & 23 & $\$ 338$ & $\$ 6,596$ & 19.5 \\
\hline Ground Floor Insulation & 3,213 & 226 & $\$ 2,060$ & $\$ 55,002$ & 26.7 \\
\hline Use Sky Lighting & 8,294 & -13 & $\$ 678$ & $\$ 4,458$ & 6.6 \\
\hline Total & 13,273 & 690 & $\$ 6,615$ & $\$ 89,817$ & 13.6 \\
\hline
\end{tabular}

Table 141. Bldg. 1103 savings and payback summary, Climate Zone 3B (EI Paso, TX).

\begin{tabular}{|l|c|c|c|c|c|}
\hline EEM & $\begin{array}{c}\text { Electrical } \\
\text { Savings } \\
(\mathrm{kWh} / \mathrm{yr})\end{array}$ & $\begin{array}{c}\text { Thermal } \\
\text { Savings } \\
\mathbf{( M i l .} \\
\text { Btu/yr) }\end{array}$ & $\begin{array}{c}\text { Annual } \\
\text { Cost } \\
\text { Savings }\end{array}$ & $\begin{array}{c}\text { Implementation } \\
\text { Costs }\end{array}$ & $\begin{array}{c}\text { Payback } \\
\text { Period } \\
\text { (yrs) }\end{array}$ \\
\hline Reduce Infiltration & 202 & 141 & $\$ 1,116$ & $\$ 9,183$ & 8.2 \\
\hline Use Condensing Furnaces & 0 & 283 & $\$ 2,202$ & $\$ 14,578$ & 6.6 \\
\hline Wall Insulation & 1,944 & 22 & $\$ 354$ & $\$ 6,596$ & 18.6 \\
\hline Ground Floor Insulation & 5,036 & 270 & $\$ 2,573$ & $\$ 55,002$ & 21.4 \\
\hline Use Sky Lighting & 8,417 & -12 & $\$ 697$ & $\$ 4,458$ & 6.4 \\
\hline Total & 15,598 & 705 & $\$ 6,950$ & $\$ 89,817$ & 12.9 \\
\hline
\end{tabular}

Table 142. Bldg. 1103 savings and payback summary, Climate Zone 3C (San Francisco, CA).

\begin{tabular}{|l|c|c|c|c|c|}
\hline EEM & $\begin{array}{c}\text { Electrical } \\
\text { Savings } \\
(\mathrm{kWh} / \mathrm{yr})\end{array}$ & $\begin{array}{c}\text { Thermal } \\
\text { Savings } \\
\mathbf{( M i l .} \\
\text { Btu/yr) }\end{array}$ & $\begin{array}{c}\text { Annual } \\
\text { Cost } \\
\text { Savings }\end{array}$ & $\begin{array}{c}\text { Implementation } \\
\text { Costs }\end{array}$ & $\begin{array}{c}\text { Payback } \\
\text { Period } \\
\text { (yrs) }\end{array}$ \\
\hline Reduce Infiltration & 1,343 & 333 & $\$ 2,717$ & $\$ 9,183$ & 3.4 \\
\hline Use Condensing Furnaces & 0 & 488 & $\$ 3,797$ & $\$ 14,578$ & 3.8 \\
\hline Wall Insulation & -72 & 50 & $\$ 382$ & $\$ 6,596$ & 17.3 \\
\hline Ground Floor Insulation & 2,687 & 509 & $\$ 4,212$ & $\$ 55,002$ & 13.1 \\
\hline Use Sky Lighting & 7,819 & -24 & $\$ 547$ & $\$ 4,458$ & 8.1 \\
\hline Total & 11,777 & 1,354 & $\$ 11,640$ & $\$ 89,817$ & 7.7 \\
\hline
\end{tabular}

Table 143. Bldg. 1103 savings and payback summary, Climate Zone 4A (Baltimore, MD).

\begin{tabular}{|l|c|c|c|c|c|}
\hline EEM & $\begin{array}{c}\text { Electrical } \\
\text { Savings } \\
(\mathrm{kWh} / \mathrm{yr})\end{array}$ & $\begin{array}{c}\text { Thermal } \\
\text { Savings } \\
(\text { Mil. } \\
\text { Btu/yr) }\end{array}$ & $\begin{array}{c}\text { Annual } \\
\text { Cost } \\
\text { Savings }\end{array}$ & $\begin{array}{c}\text { Implementation } \\
\text { Costs }\end{array}$ & $\begin{array}{c}\text { Payback } \\
\text { Period } \\
\text { (yrs) }\end{array}$ \\
\hline Reduce Infiltration & 61 & 102 & $\$ 799$ & $\$ 9,183$ & 11.5 \\
\hline Use Condensing Furnaces & 0 & 470 & $\$ 3,657$ & $\$ 14,578$ & 4.0 \\
\hline Wall Insulation & 1,324 & 16 & $\$ 249$ & $\$ 6,596$ & 26.5 \\
\hline Ground Floor Insulation & 2,790 & 230 & $\$ 2,051$ & $\$ 55,002$ & 26.8 \\
\hline Use Sky Lighting & 8,060 & -14 & $\$ 648$ & $\$ 4,458$ & 6.9 \\
\hline Total & 12,235 & 803 & $\$ 7,396$ & $\$ 89,817$ & 12.1 \\
\hline
\end{tabular}


Table 144. Bldg. 1103 savings and payback summary, Climate Zone 4B (Albuquerque, NM).

\begin{tabular}{|l|c|c|c|c|c|}
\hline EEM & $\begin{array}{c}\text { Electrical } \\
\text { Savings } \\
(\mathrm{kWh} / \mathrm{yr})\end{array}$ & $\begin{array}{c}\text { Thermal } \\
\text { Savings } \\
\text { (Mil. } \\
\text { Btu/yr) }\end{array}$ & $\begin{array}{c}\text { Annual } \\
\text { Cost } \\
\text { Savings }\end{array}$ & $\begin{array}{c}\text { Implementation } \\
\text { Costs }\end{array}$ & $\begin{array}{c}\text { Payback } \\
\text { Period } \\
\text { (yrs) }\end{array}$ \\
\hline Reduce Infiltration & 179 & 114 & $\$ 904$ & $\$ 9,183$ & 10.2 \\
\hline Use Condensing Furnaces & 0 & 430 & $\$ 3,345$ & $\$ 14,578$ & 4.4 \\
\hline Wall Insulation & 1,542 & 23 & $\$ 324$ & $\$ 6,596$ & 20.4 \\
\hline Ground Floor Insulation & 3,782 & 319 & $\$ 2,837$ & $\$ 55,002$ & 19.4 \\
\hline Use Sky Lighting & 8,204 & -15 & $\$ 654$ & $\$ 4,458$ & 6.8 \\
\hline Total & 13,708 & 870 & $\$ 8,056$ & $\$ 89,817$ & 11.1 \\
\hline
\end{tabular}

Table 145. Bldg. 1103 savings and payback summary, Climate Zone 4C (Seattle, WA).

\begin{tabular}{|l|c|c|c|c|c|}
\hline EEM & $\begin{array}{c}\text { Electrical } \\
\text { Savings } \\
(\mathrm{kWh} / \mathrm{yr})\end{array}$ & $\begin{array}{c}\text { Thermal } \\
\text { Savings } \\
\mathbf{( M i l .} \\
\text { Btu/yr) }\end{array}$ & $\begin{array}{c}\text { Annual } \\
\text { Cost } \\
\text { Savings }\end{array}$ & $\begin{array}{c}\text { Implementation } \\
\text { Costs }\end{array}$ & $\begin{array}{c}\text { Payback } \\
\text { Period } \\
\text { (yrs) }\end{array}$ \\
\hline Reduce Infiltration & 1,017 & 192 & $\$ 1,589$ & $\$ 9,183$ & 5.8 \\
\hline Use Condensing Furnaces & 0 & 592 & $\$ 4,606$ & $\$ 14,578$ & 3.2 \\
\hline Wall Insulation & -4 & 31 & $\$ 241$ & $\$ 6,596$ & 27.4 \\
\hline Ground Floor Insulation & 2,391 & 429 & $\$ 3,562$ & $\$ 55,002$ & 15.4 \\
\hline Use Sky Lighting & 7,209 & -21 & $\$ 514$ & $\$ 4,458$ & 8.7 \\
\hline Total & 10,613 & 1,222 & $\$ 10,504$ & $\$ 89,817$ & 8.6 \\
\hline
\end{tabular}

Table 146. Bldg. 1103 savings and payback summary, Climate Zone 5A (Chicago, IL).

\begin{tabular}{|l|c|c|c|c|c|}
\hline EEM & $\begin{array}{c}\text { Electrical } \\
\text { Savings } \\
(\mathrm{kWh} / \mathrm{yr})\end{array}$ & $\begin{array}{c}\text { Thermal Savings } \\
\text { (Mil. Btu/yr) }\end{array}$ & $\begin{array}{c}\text { Annual } \\
\text { Cost } \\
\text { Savings }\end{array}$ & $\begin{array}{c}\text { Implementation } \\
\text { Costs }\end{array}$ & $\begin{array}{c}\text { Payback } \\
\text { Period } \\
\text { (yrs) }\end{array}$ \\
\hline Reduce Infiltration & 259 & 94 & $\$ 756$ & $\$ 9,183$ & 12.2 \\
\hline Use Condensing Furnaces & 0 & 542 & $\$ 4,217$ & $\$ 14,578$ & 3.5 \\
\hline Wall Insulation & 1,006 & 17 & $\$ 227$ & $\$ 6,596$ & 29.1 \\
\hline Ground Floor Insulation & 2,681 & 207 & $\$ 1,862$ & $\$ 55,002$ & 29.5 \\
\hline Use Sky Lighting & 8,011 & -13 & $\$ 651$ & $\$ 4,458$ & 6.8 \\
\hline Total & 11,957 & 847 & $\$ 7,712$ & $\$ 89,817$ & 11.6 \\
\hline
\end{tabular}

Table 147. Bldg. 1103 savings and payback summary, Climate Zone 5B (Colorado Springs, C0).

\begin{tabular}{|l|c|c|c|c|c|}
\hline EEM & $\begin{array}{c}\text { Electrical } \\
\text { Savings } \\
(\mathrm{kWh} / \mathrm{yr})\end{array}$ & $\begin{array}{c}\text { Thermal Savings } \\
\text { (Mil. Btu/yr) }\end{array}$ & $\begin{array}{c}\text { Annual } \\
\text { Cost } \\
\text { Savings }\end{array}$ & $\begin{array}{c}\text { Implementation } \\
\text { Costs }\end{array}$ & $\begin{array}{c}\text { Payback } \\
\text { Period } \\
\text { (yrs) }\end{array}$ \\
\hline Reduce Infiltration & 694 & 125 & $\$ 1,038$ & $\$ 9,183$ & 8.8 \\
\hline Use Condensing Furnaces & 0 & 564 & $\$ 4,388$ & $\$ 14,578$ & 3.3 \\
\hline Wall Insulation & 598 & 26 & $\$ 258$ & $\$ 6,596$ & 25.5 \\
\hline Ground Floor Insulation & 2,740 & 349 & $\$ 2,973$ & $\$ 55,002$ & 18.5 \\
\hline Use Sky Lighting & 7,982 & -18 & $\$ 609$ & $\$ 4,458$ & 7.3 \\
\hline Total & 12,015 & 1,046 & $\$ 9,266$ & $\$ 89,817$ & 9.7 \\
\hline
\end{tabular}


Table 148. Bldg. 1103 savings and payback summary, Climate Zone 6A (Burlington, VT).

\begin{tabular}{|l|c|c|c|c|c|}
\hline EEM & $\begin{array}{c}\text { Electrical } \\
\text { Savings } \\
\text { (kWh/yr) }\end{array}$ & $\begin{array}{c}\text { Thermal Savings } \\
\text { (Mil. Btu/yr) }\end{array}$ & $\begin{array}{c}\text { Annual } \\
\text { Cost } \\
\text { Savings }\end{array}$ & $\begin{array}{c}\text { Implementation } \\
\text { Costs }\end{array}$ & $\begin{array}{c}\text { Payback } \\
\text { Period } \\
\text { (yrs) }\end{array}$ \\
\hline Reduce Infiltration & 595 & 123 & $\$ 1,013$ & $\$ 9,183$ & 9.1 \\
\hline Use Condensing Furnaces & 0 & 587 & $\$ 4,567$ & $\$ 14,578$ & 3.2 \\
\hline Wall Insulation & 448 & 18 & $\$ 182$ & $\$ 6,596$ & 36.2 \\
\hline Ground Floor Insulation & 2,280 & 210 & $\$ 1,848$ & $\$ 55,002$ & 29.8 \\
\hline Use Sky Lighting & 7,892 & -13 & $\$ 640$ & $\$ 4,458$ & 7.0 \\
\hline Total & 11,215 & 924 & $\$ 8,242$ & $\$ 89,817$ & 10.9 \\
\hline
\end{tabular}

Table 149. Bldg. 1103 savings and payback summary, Climate Zone 6B (Helena, MT).

\begin{tabular}{|l|c|c|c|c|c|}
\hline EEM & $\begin{array}{c}\text { Electrical } \\
\text { Savings } \\
(\mathrm{kWh} / \mathbf{y r})\end{array}$ & $\begin{array}{c}\text { Thermal Savings } \\
\text { (Mil. Btu/yr) }\end{array}$ & $\begin{array}{c}\text { Annual } \\
\text { Cost } \\
\text { Savings }\end{array}$ & $\begin{array}{c}\text { Implementation } \\
\text { Costs }\end{array}$ & $\begin{array}{c}\text { Payback } \\
\text { Period } \\
\text { (yrs) }\end{array}$ \\
\hline Reduce Infiltration & 434 & 129 & $\$ 1,044$ & $\$ 9,183$ & 8.8 \\
\hline Use Condensing Furnaces & 0 & 623 & $\$ 4,847$ & $\$ 14,578$ & 3.0 \\
\hline Wall Insulation & 623 & 26 & $\$ 261$ & $\$ 6,596$ & 25.3 \\
\hline Ground Floor Insulation & 2,497 & 296 & $\$ 2,537$ & $\$ 55,002$ & 21.7 \\
\hline Use Sky Lighting & 7,716 & -17 & $\$ 592$ & $\$ 4,458$ & 7.5 \\
\hline Total & 11,270 & 1,057 & $\$ 9,282$ & $\$ 89,817$ & 9.7 \\
\hline
\end{tabular}

Table 150. Bldg. 1103 savings and payback summary, Climate Zone 7A (Duluth, MN).

\begin{tabular}{|l|c|c|c|c|c|}
\hline EEM & $\begin{array}{c}\text { Electrical } \\
\text { Savings } \\
(\mathrm{kWh} / \mathrm{yr})\end{array}$ & $\begin{array}{c}\text { Thermal } \\
\text { Savings } \\
\mathbf{( M i l .} \\
\text { Btu/yr) }\end{array}$ & $\begin{array}{c}\text { Annual } \\
\text { Cost } \\
\text { Savings }\end{array}$ & $\begin{array}{c}\text { Implementation } \\
\text { Costs }\end{array}$ & $\begin{array}{c}\text { Payback } \\
\text { Period } \\
\text { (yrs) }\end{array}$ \\
\hline Reduce Infiltration & 622 & 117 & $\$ 969$ & $\$ 9,183$ & 9.5 \\
\hline Use Condensing Furnaces & 0 & 699 & $\$ 5,438$ & $\$ 14,578$ & 2.7 \\
\hline Wall Insulation & 160 & 22 & $\$ 186$ & $\$ 6,596$ & 35.4 \\
\hline Ground Floor Insulation & 1,807 & 251 & $\$ 2,122$ & $\$ 55,002$ & 25.9 \\
\hline Use Sky Lighting & 7,761 & -16 & $\$ 604$ & $\$ 4,458$ & 7.4 \\
\hline Total & 10,351 & 1,073 & $\$ 9,320$ & $\$ 89,817$ & 9.6 \\
\hline
\end{tabular}

Table 151. Bldg. 1103 savings and payback summary, Climate Zone 8A (Fairbanks, AK).

\begin{tabular}{|l|c|c|c|c|c|}
\hline EEM & $\begin{array}{c}\text { Electrical } \\
\text { Savings } \\
(\mathrm{kWh} / \mathrm{yr})\end{array}$ & $\begin{array}{c}\text { Thermal } \\
\text { Savings } \\
\text { (Mil. } \\
\text { Btu/yr) }\end{array}$ & $\begin{array}{c}\text { Annual } \\
\text { Cost } \\
\text { Savings }\end{array}$ & $\begin{array}{c}\text { Implementation } \\
\text { Costs }\end{array}$ & $\begin{array}{c}\text { Payback } \\
\text { Period } \\
\text { (yrs) }\end{array}$ \\
\hline Reduce Infiltration & 558 & 119 & $\$ 978$ & $\$ 9,183$ & 9.4 \\
\hline Use Condensing Furnaces & 0 & 759 & $\$ 5,905$ & $\$ 14,578$ & 2.5 \\
\hline Wall Insulation & 48 & 17 & $\$ 137$ & $\$ 6,596$ & 48.2 \\
\hline Ground Floor Insulation & 1,396 & 232 & $\$ 1,936$ & $\$ 55,002$ & 28.4 \\
\hline Use Sky Lighting & 6,031 & -15 & $\$ 450$ & $\$ 4,458$ & 9.9 \\
\hline Total & 8,034 & 1,113 & $\$ 9,414$ & $\$ 89,817$ & 9.5 \\
\hline
\end{tabular}


Figure 88. Bldg. 115, Fort Bliss, annual cost savings resulting from EEM "Reduce Infiltration," by climate zone.

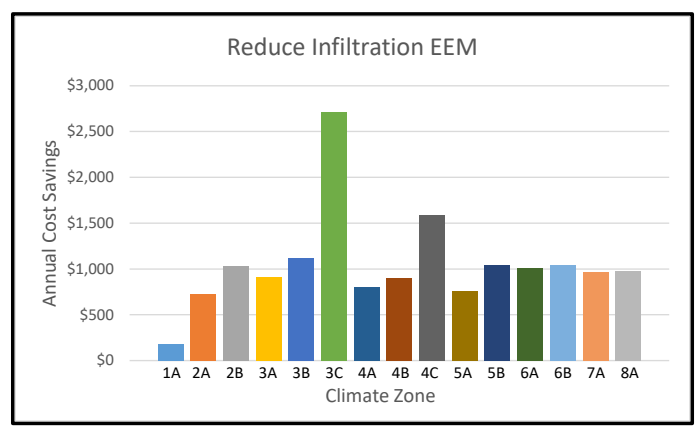

Figure 90. Bldg. 115, Fort Bliss, annual cost savings resulting from EEM "Use Condensing Furnaces," by climate zone.

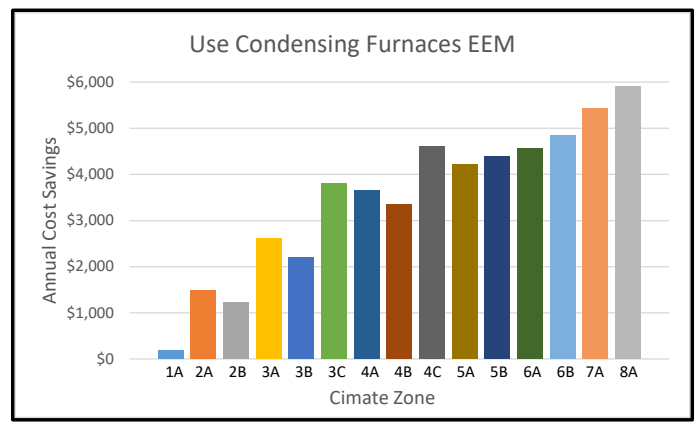

Figure 92. Bldg. 115, Fort Bliss, annual cost savings resulting from EEM "Wall Insulation EEM," by climate zone.

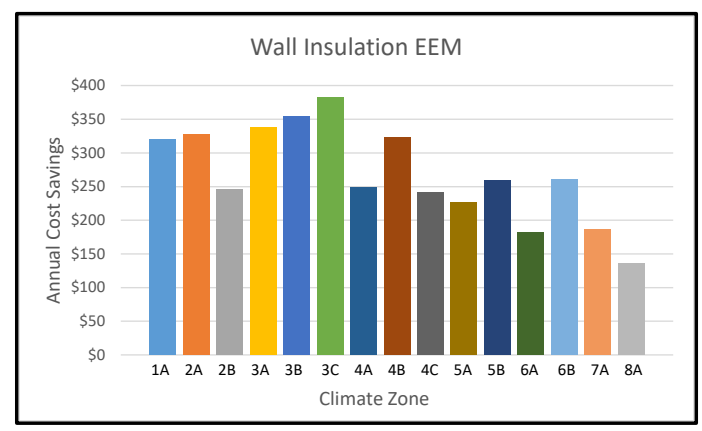

Figure 89. Bldg. 115, Fort Bliss, simple payback resulting from EEM "Reduce Infiltration," by climate zone.

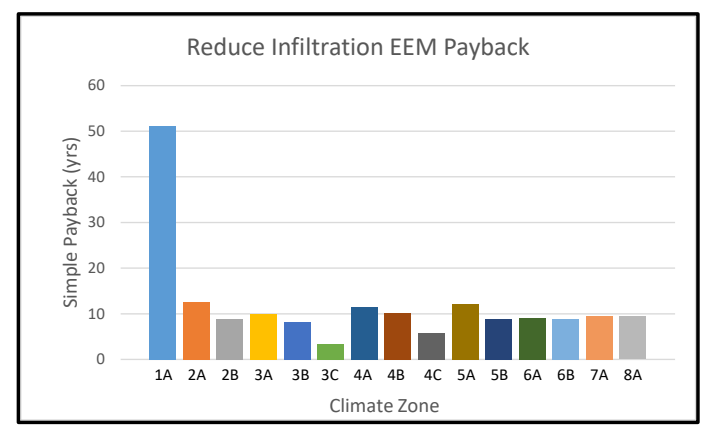

Figure 91. Bldg. 115, Fort Bliss, simple payback resulting from EEM "Use Condensing Furnaces," by climate zone.

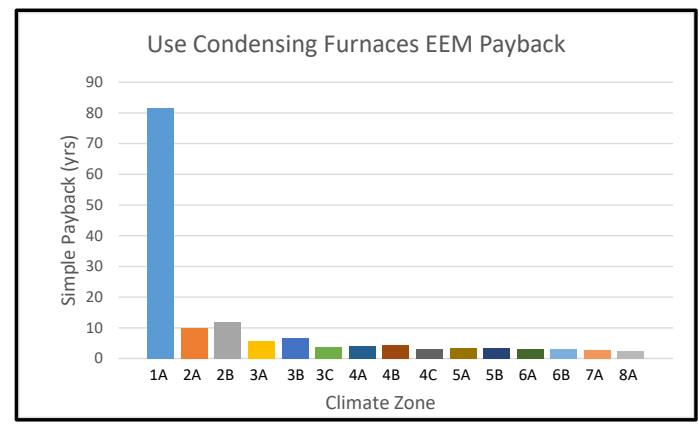

Figure 93. Bldg. 115, Fort Bliss, simple payback resulting from EEM "Wall Insulation EEM," by climate zone.

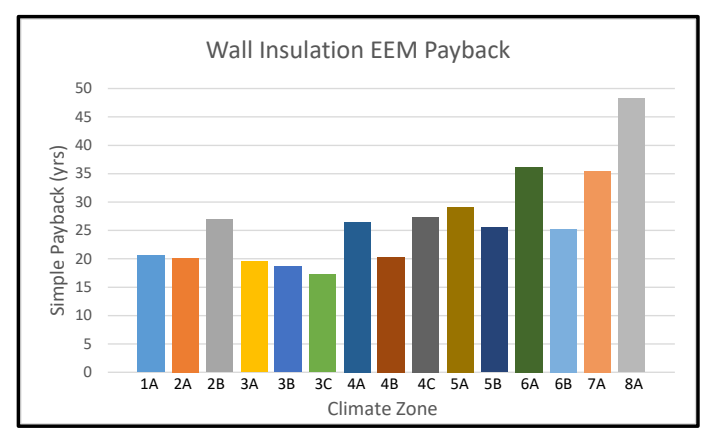


Figure 94. BIdg. 115, Fort Bliss, annual cost savings resulting from EEM "Ground Floor Insulation EEM," by climate zone.

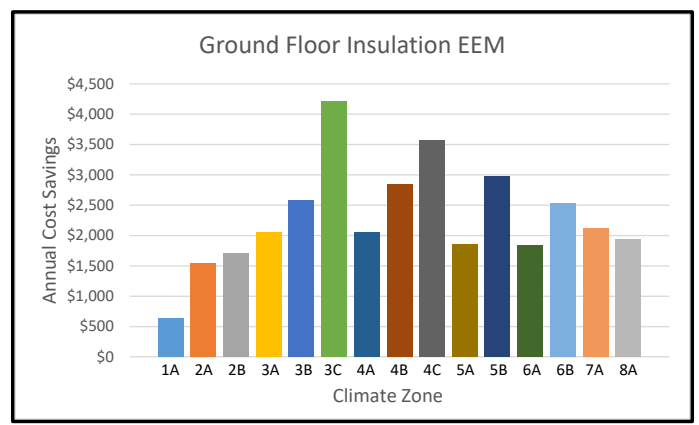

Figure 96. Bldg. 115, Fort Bliss, annual cost savings resulting from EEM "Use Skylighting EEM," by climate zone.

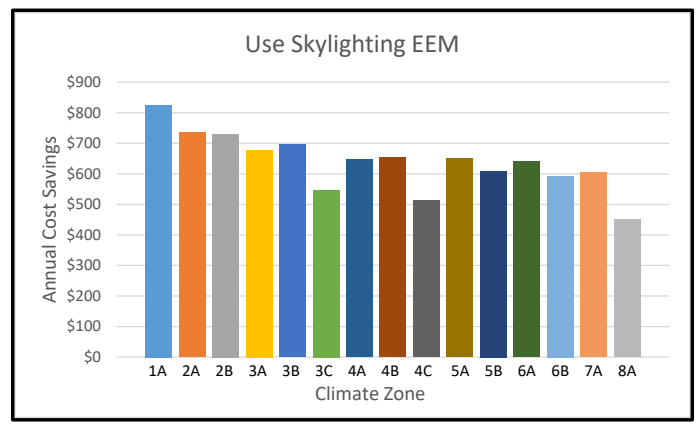

Figure 98. Bldg. 115, Fort Bliss, total EEM

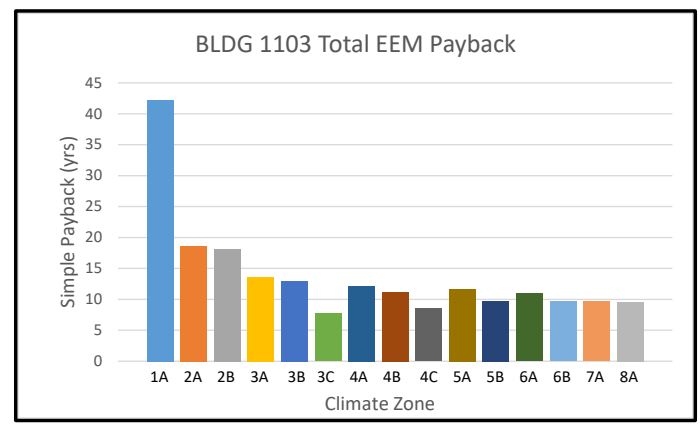

\section{payback.}

Figure 95. Bldg. 115, Fort Bliss, simple payback resulting from EEM "Ground Floor Insulation EEM," by climate zone.

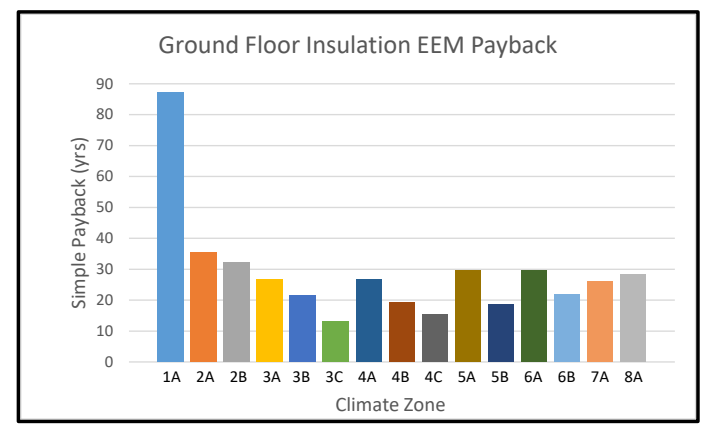

Figure 97. Bldg. 115, Fort Bliss, simple payback resulting from EEM "Use Skylighting EEM," by climate zone.

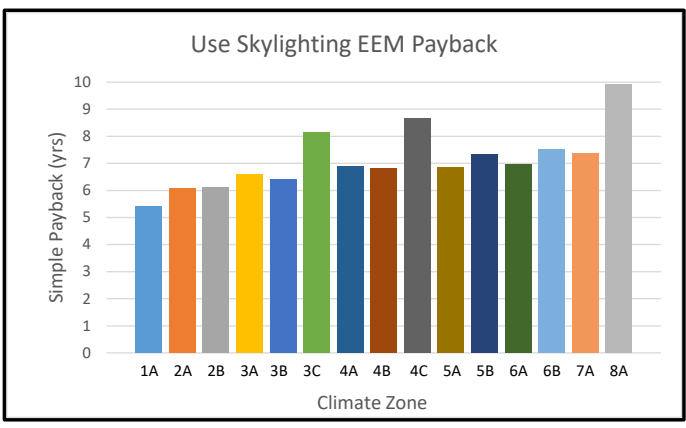




\section{Historic Building Energy Savings Spreadsheet Tool}

As part of the research in developing this report, an Excel spreadsheet was developed to compile the results. It contains calculations of energy and cost savings. The utility costs used in calculations (natural gas and electricity) are a DoD average. These quantities can be easily changed if needed to re-calculate the dollar savings for a particular location. The tool and the eQuest models are available at the same Internet location as this report. 


\section{Summary and Conclusions}

This work reviewed the DoD stock of buildings either declared historical or deemed eligible for historic building status. Six buildings at Fort Sill, OK, that represent commonly found building types were selected for study of potential EEMs. Computer models of the buildings energy use were developed and used to estimate the potential energy savings of the various EEMs. Costs for the EEMs were estimated, simple paybacks calculated, and the results were further extrapolated to the 15 U.S. climate zones and summarized. The results from a previous study about historic buildings energy use at Fort Bliss (Underwood et al. 2011) were also used to develop similar concepts.

The results were used to develop a guide to suggest EEMs appropriate for use with historical buildings, and a general guide to the energy implications of using those EEMs in various climates. The results are summarized as follows:

- Note that the most general conclusion is that -as one might intuitively expect- all EEMs yield smaller savings and are therefore less economical in milder climates.

- Replacement of mechanical equipment controls (to allow setpoint and schedule changes) was by far the most cost effective measure with an average simple payback of less than 2 months for all buildings in all climate zones.

- Reduction of infiltration was also very effective with a payback of less than 5 years in all but $8 \%$ of the climate zone building combinations.

- Improvement of Wall insulation on the inside of exterior walls was also very cost effective (with a simple payback of less than 5 years) in nine of 15 zones, most of which were in the colder zones.

- Although Lighting retrofits typically yield very good paybacks, lighting retrofits did not yield very good paybacks in most of the modeled buildings for two reasons: (1) the lighting density in the buildings modeled was very low so almost no areas were found to be overlit, and (2) all of the buildings had been retrofitted with energy efficient lighting. It was therefore decided not to model the base case with less efficient lighting or with overlit conditions because lighting retrofits have already been done in most DoD buildings. This differs from the ap- 
proach taken for other EEMs such as scheduling in which, after modeling the building as found (referred to "As Is" in the modeling), the building was modeled without the EEM (scheduling) to determine the baseline. Therefore this result should regarded as an anomaly; in general, lighting controls retrofits should always considered.

- Improvement of Roof/Attic Insulation was found to rarely be a very good saver. Only Bldg. 441 had simple paybacks of less than 15 years, and then only in six (cooler) climate zones.

- Replacement of Mechanical Equipment was found to have a relatively good payback. As expected, replacing chillers in warm climates and boilers in cold climates has a much better payback than the reverse.

- The use of Renewable Energy was found to be physically feasible in two buildings (3419 and 1803). Wind turbines would distract from the historic nature of the area. Photovoltaic (PV) panels could be installed on the roof of Bldg. 3419 as could water heating panels. However, there was not enough demand for hot water in this administrative building to justify this measure. PV has potential on Bldg. 3419, but the payback is relatively long at 21 to 40 years. In Bldg. 1803, the replacement of conventional boiler/chiller with ground source heat pumps and was found to have a good payback ( 1 to 7 years) depending on climate zone. Note that, although good payback was found even in the colder climate zones, it may not be practical in the colder climate zones due to the need for significant amounts of supplemental heat and issues with permafrost in the extreme climates. Also of note is that no costs were included for supplemental heating that may be needed in some climates.

- Improvement of Ground Floor Insulation was found to be somewhat cost effective with paybacks ranging from 5.4 to 9.9 years. This was found feasible in only one building, which has a crawl space type foundation that allows relatively easy access to insulate the floor.

Tables 152 to 160 summarize the analysis in the form of simple payback (Initial cost[\$]/Savings[\$]/year) for the various buildings and climate zones. Note that Bldgs. 441, 462, 463, 750, 1803, and 3419 are located at Fort Sill, OK, and Bldgs. 1, 115, and 1103 are located at Fort Bliss, TX.

It is anticipated that the results of this work will allow those involved in the process of identifying renovations in historic buildings, such as energy auditors and cultural resources persons, to specify projects that will improve the energy performance of historic buildings while accommodating 
their unique aspects and requirements. This is an important issue since, as the stock of historic buildings continues to grow, there will be an increasing need for measures to meet various energy goals and requirements in these historically significant structures.

The results will also aid in development of more renewable energy projects in historic buildings that will meet many Federal directives, orders, and goals. The results will also assist in defining adaptable reuse of historical buildings by providing various alternatives for renovations to energy systems that are acceptable in historic buildings. This is expected to result in more projects being performed on historic structures. In turn, this will result in more comfortable, more habitable, better preserved facilities that will better support the Nation's military readiness. 

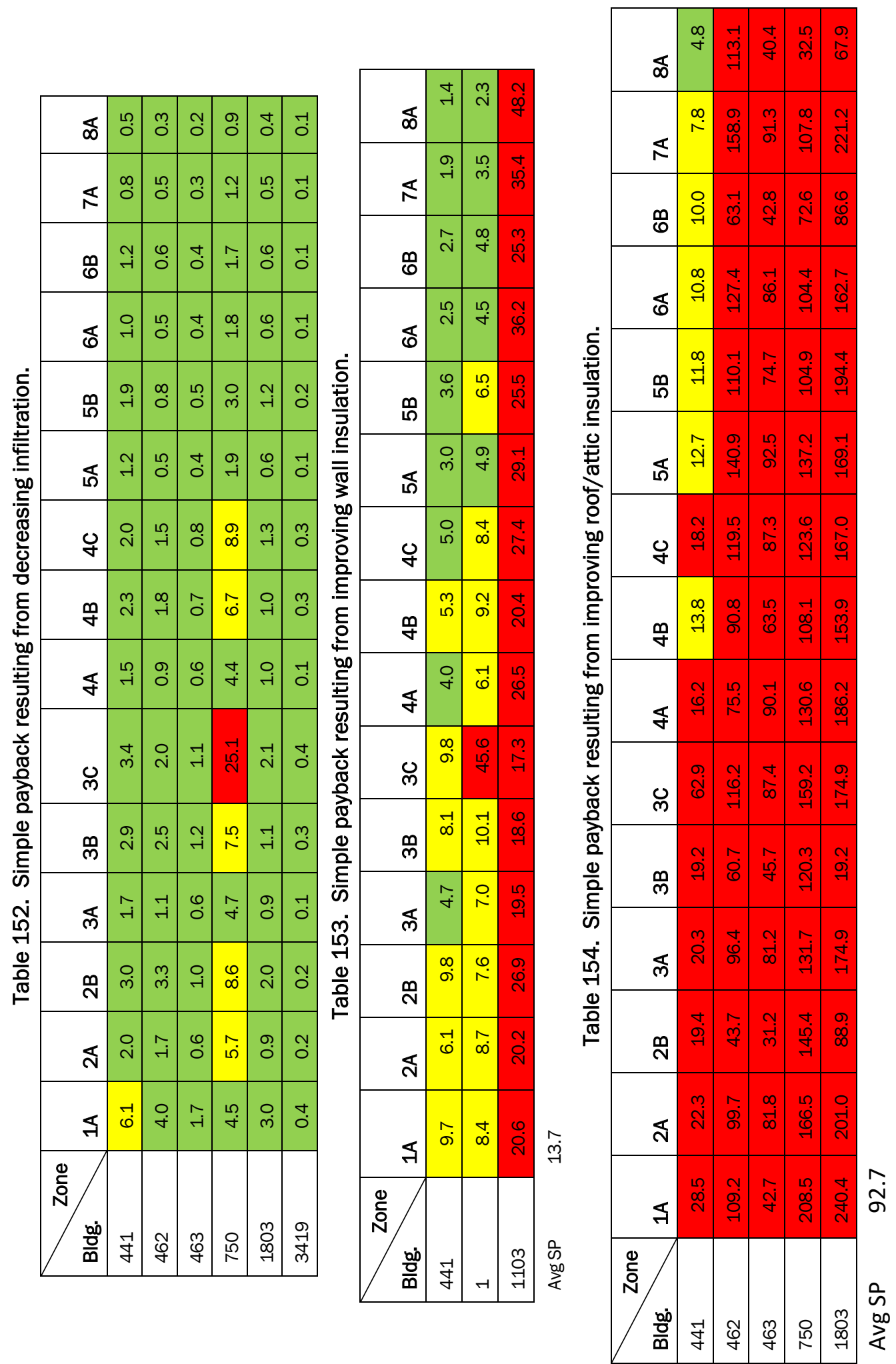

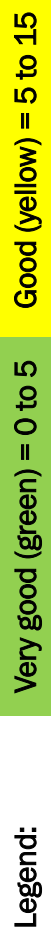




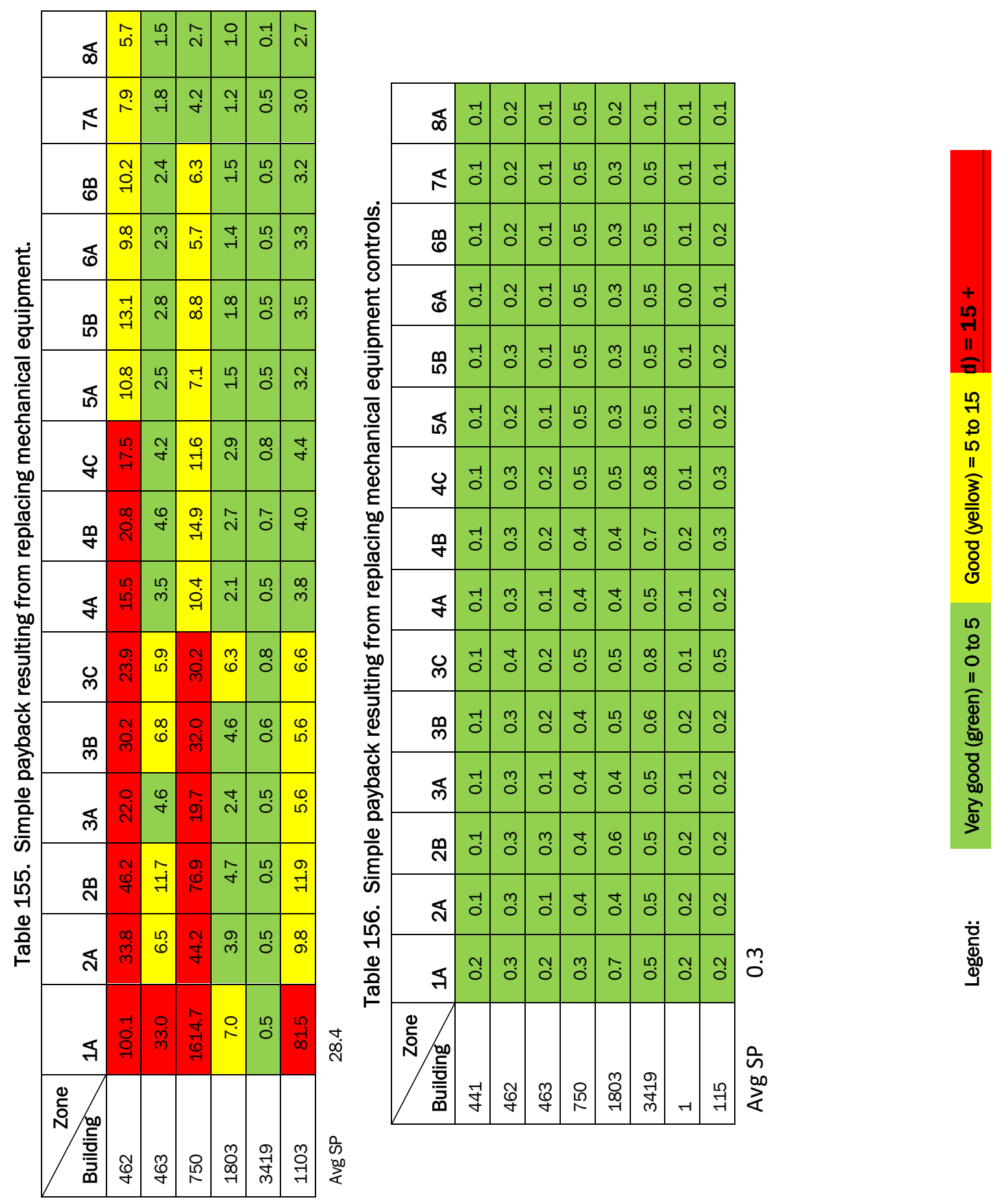



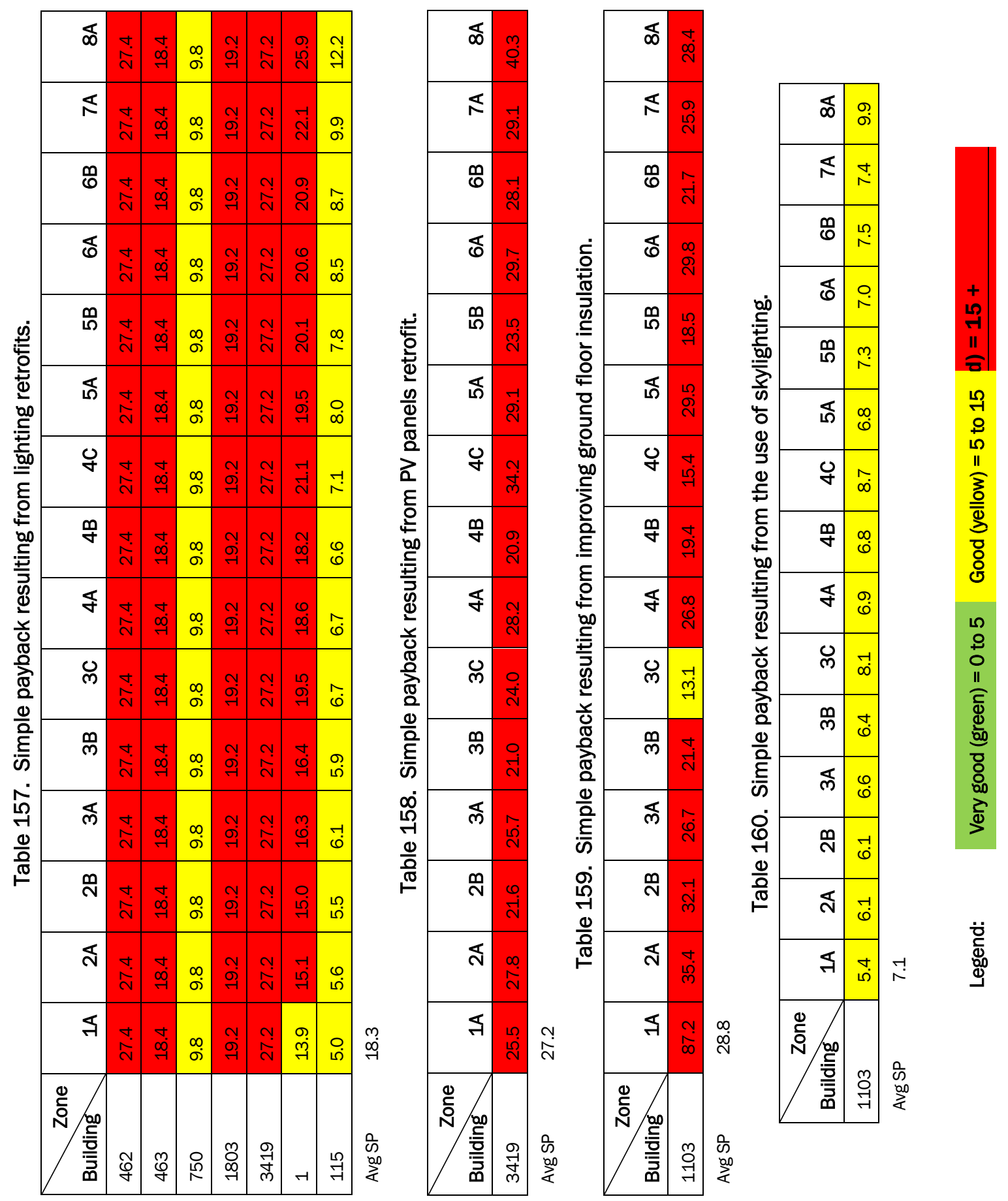

홍 


\section{References}

Barbose, Galen, and Naim Darghouth. 2016. Tracking the Sum IX: The Installed Price of Residential and Non-Residential Photovoltaic Systems in the United States.

Berkeley, CA: Lawrence Berkley National Laboratory (LBNL), https://eetd.Ibl.gov/sites/all/files/tracking_the_sun_ix_report.pdf

Energy Independence and Security Act of 2007 (EISA). Public Law 110-140. 110 th Congress, https://www.gpo.gov/fdsys/pkg/PLAW-110publ140/html/PLAW-110publ140.htm

Energy Policy Act (EPACT). 2005. Public Law 109-58-Aug. 8, 2005, http://energy.gov/sites/prod/files/2013/10/f3/epact_2005.pdf

Geothermal Genius. 2009. By the numbers - Real results of a home geothermal installation. geothermal: HEAT AND COOL WITH DIRT not oil. Web page, http://www.geothermalgenius.org/thinking-of-buying/geothermal-installation-by-the-numbersin-pennsylvania.html

Hirsch, James A. 2010. eQUEST: The Quick Energy Simulation Tool. Web page. Camarillo, CA: James J. Hirsch \& Associates, http://www.doe2.com/equest/

- 2016. Welcome to DOE2.com: The Home of DOE-2 Based Building Energy Use and Cost Analysis Software. Web page. Camarillo, CA: James J. Hirsch \& Associates, http://www.doe2.com/

Secretary of the Army (SA). 2014. Net Zero Installations Policy. Army Directive 2014-02. Washington, DC: SA, http://www.asaie.army.mil/Public/ES/doc/Army\%20Directive\%20201402\%20(NZ\%20Policy).pdf

Sin, Jennifer, Tina Chui, Rosemarie E. Woodbury, Adam D. Smith, and Sunny E. Adams. Application of Renewable Energy Sources at Fort Bragg; A Guide to Applying Renewable Energy Sources on Historic Buildings. ERDC/CERL SR-12-2. Champaign, IL: Engineer Research and Development Center, Construction Engineering Research Laboratory (ERDC-CERL).

Underwood, David M., Alexander M. Zhivov, Richard J. Liesen, William J. Stein, Alfred Woody, Sunny Adams, Chad Grosshart, Halley Fitzpatrick, Georg Zielke, and Michael DiPaolo. 2011. Energy Assessment of Historical Buildings at Fort Bliss, $T X$. Champaign, IL: Engineer Research and Development Center, Construction Engineering Research Laboratory (ERDC-CERL).

White House, The. 2015. Planning for Federal Sustainability in the Next Decade. Executive Order EO 13693. Washington, DC: The White House, Office of the Press Secretary, https://www.whitehouse.gov/the-press-office/2015/03/19/executiveorder-planning-federal-sustainability-next-decade

2007. Strengthening Federal Environmental, Energy, and Transportation Management. EO 13423. Washington, DC: The White House, Office of the Press Secretary, https://energy.gov/sites/prod/files/nepapub/nepa_documents/RedDont/ReqE013423envtlmgmt.pdf 
. 1999. Greening the Government through Efficient Energy Management. Executive Order EO 13123. Washington, DC: The White House, Office of the Press Secretary, https://ceq.doe.gov/nepa/regs/eos/e013123.html

Zhang, J., G. Liu, R. G. Lutes, and M. R. Brambley. 2013. Energy Savings for Occupancy - Based Control (OBC) of Variable - Air - Volume (VAV) Systems. PNNL-22072. Richland, WA: Pacific Northwest National Laboratory (PNNL),

http://www.pnnl.gov/main/publications/external/technical_reports/PNNL-22072.pdf 


\section{Acronyms and Abbreviations}

\begin{tabular}{|c|c|}
\hline $\begin{array}{l}\text { Term } \\
\mathrm{ACH}\end{array}$ & $\begin{array}{l}\text { Definition } \\
\text { air changes per hour }\end{array}$ \\
\hline AFB & Air Force Base \\
\hline AHU & Air Handling Unit \\
\hline ANSI & American National Standards Institute \\
\hline $\mathrm{Bn}$ & Battalion \\
\hline Btu & British Thermal Unit \\
\hline CBECS & Commercial Buildings Energy Consumption Survey \\
\hline CDD & Total Cooling Degree Days \\
\hline CEERD & US Army Corps of Engineers, Engineer Research and Development Center \\
\hline CERL & Construction Engineering Research Laboratory \\
\hline COP & Coefficient of Performance \\
\hline DDC & Direct Digital Control \\
\hline DNR & Department of Natural Resources \\
\hline DoD & U.S. Department of Defense \\
\hline $\mathrm{DX}$ & Direct Expansion \\
\hline ECM & Energy Conservation Measure \\
\hline EEM & Energy Efficiency Measure \\
\hline EISA & U.S. Energy Independence and Security Act of 2007 \\
\hline EO & Executive Order \\
\hline EPACT & Energy Policy Act \\
\hline ERDC & U.S. Army Engineer Research and Development Center \\
\hline ERDC-CERL & $\begin{array}{l}\text { Engineer Research and Development Center, Construction Engineering } \\
\text { Research Laboratory }\end{array}$ \\
\hline EUI & Energy Use Intensity \\
\hline FCU & Fan-Coil Unit \\
\hline $\mathrm{FY}$ & Fiscal Year \\
\hline HDD & Heating Degree Day \\
\hline HPA & Historical Preservation Act \\
\hline $\mathrm{HQ}$ & Headquarters \\
\hline HQIIS & (Army) Headquarters Installation Information System \\
\hline HSC & Historic Status Code \\
\hline HVAC & Heating, Ventilating, and Air-Conditioning \\
\hline IP & Inch -Pound \\
\hline LBNL & Lawrence Berkeley National Laboratory \\
\hline LED/INC & Light Emitting Diode/Incandescent \\
\hline MBH & $1000 \mathrm{Btu} / \mathrm{hr}$ \\
\hline MMBtu & million Btu \\
\hline N/A & Not Applicable \\
\hline NREL & National Renewable Energy Laboratory \\
\hline
\end{tabular}




\begin{tabular}{ll} 
Term & Definition \\
NRHP & National Register of Historic Places \\
NSN & National Supply Number \\
OASD(EI\&E) & Office of the Assistant Secretary of Defense, Energy, Installations, and \\
& Environment \\
OBC & Occupancy-Based Control \\
OMB & Office of Management and Budget \\
PNNL & Pacific Northwest National Laboratory \\
PO & Post Office \\
PV & PhotoVoltaic \\
PX & Post Exchange \\
RPAD & (DoD) Real Property Assets Database \\
SA & Secretary of the Army \\
SAM & System Advisory Model \\
SAR & Same As Report \\
SF & Standard Form \\
SHPO & State Historic Preservation Office \\
SI & Systeme Internationale \\
SP & Static Pressure \\
USMC & US Marine Corps \\
VAV & Variable Air Volume \\
WHS & Washington Headquarters Services \\
WWI & World War I \\
WWII & World War II \\
& \\
\hline
\end{tabular}




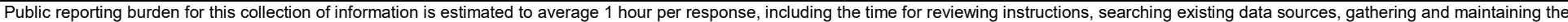

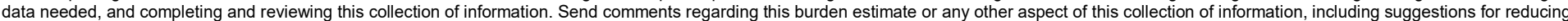

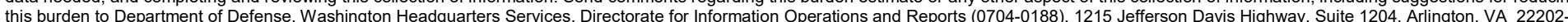

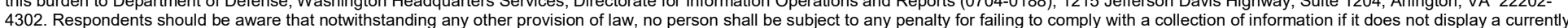
4302. Respondents should be aware that notwithstanding any other provision of law, no person sh
valid OMB control number. PLEASE DO NOT RETURN YOUR FORM TO THE ABOVE ADDRESS.

\begin{tabular}{|l|r} 
valid OMB control number. PLEASE DO NOT RETURN YOUR FORM TO THE ABOVE ADDRESS. \\
\hline 1. REPORT DATE (DD-MM-YYYY)
\end{tabular}
2. REPORT TYPE Final
$01 / 31 / 2017$

\section{TITLE AND SUBTITLE}

Energy Conservation in Historic Buildings

\section{AUTHOR(S)}

David M. Underwood, Brett N. Garret, and Tapan C. Patel

\section{DATES COVERED (From - To)}

5a. CONTRACT NUMBER

\section{5b. GRANT NUMBER}

5c. PROGRAM ELEMENT

Legacy Resource Management Program

5d. PROJECT NUMBER

15-777

5e. TASK NUMBER

5f. WORK UNIT NUMBER

8. PERFORMING ORGANIZATION REPORT NUMBER

ERDC/CERL TR-17-2

U.S. Army Engineer Research and Development Center (ERDC)

Construction Engineering Research Laboratory (CERL)

PO Box 9005

Champaign, IL 61826-9005

\section{SPONSORING / MONITORING AGENCY NAME(S) AND ADDRESS(ES)}

Office of the Assistant Secretary of Defense for Energy, Installations, and Environment (OASD[EI\&E]) 3400 Defense Pentagon, Room 3B856A

Washington, DC 20301-3400

10

10. SPONSOR/MONITOR'S ACRONYM(S) OASD(EI\&E)

11. SPONSOR/MONITOR'S REPORT NUMBER(S)

\section{DISTRIBUTION / AVAILABILITY STATEMENT}

Approved for public release; distribution is unlimited.

\section{SUPPLEMENTARY NOTES}

\section{ABSTRACT}

This work reviewed the U.S. Department of Defense (DoD) stock of buildings that has either been declared historical or deemed eligible for historic building status. Six buildings at Fort Sill, OK that represent commonly found buildings were selected to be studied for potential Energy Efficiency Measures (EEMs). Three historic buildings at Fort Bliss were also included in the analysis. Computer models of the buildings energy use were developed and used to estimate the potential energy savings of the various EEMs. Costs for the EEMs were estimated, simple paybacks were calculated, and the results were extrapolated to the 15 U.S. climate zones and summarized. A list of EEMs that may be applicable to historic buildings and a general guide to their effectiveness in various climates was developed.

\section{SUBJECT TERMS}

Energy consumption--Cost effectiveness, Historic buildings, Historic preservation Buildings--Repair and reconstruction, Military bases

\section{SECURITY CLASSIFICATION OF:}

a. REPORT
Unclassified

\section{b. ABSTRACT \\ Unclassified}

17. LIMITATION
OF ABSTRACT
SAR

THIS PAGE

Unclassified
18. NUMBER OF PAGES

125 19a. NAME OF RESPONSIBLE PERSON

19b. TELEPHONE NUMBER (include area code) 